\title{
Identification and Evaluation of Facilitation Techniques for Decommissioning Light Water Power Reactors
}

Prepared by T. S. LaGuardia, J. F. Risley

TLG Engineering, Inc.

Prepared for

U.S. Nuclear Regulatory

Commission

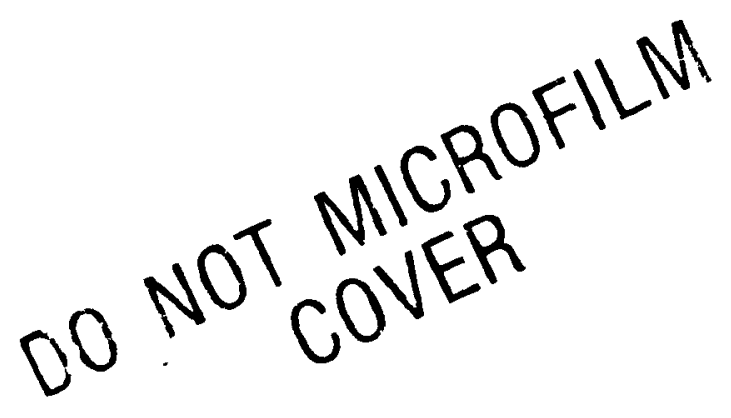




\section{DISCLAIMER}

This report was prepared as an account of work sponsored by an agency of the United States Government. Neither the United States Government nor any agency Thereof, nor any of their employees, makes any warranty, express or implied, or assumes any legal liability or responsibility for the accuracy, completeness, or usefulness of any information, apparatus, product, or process disclosed, or represents that its use would not infringe privately owned rights. Reference herein to any specific commercial product, process, or service by trade name, trademark, manufacturer, or otherwise does not necessarily constitute or imply its endorsement, recommendation, or favoring by the United States Government or any agency thereof. The views and opinions of authors expressed herein do not necessarily state or reflect those of the United States Government or any agency thereof. 


\section{DISCLAIMER}

Portions of this document may be illegible in electronic image products. Images are produced from the best available original document. 


\section{NOTICE}

This report was prepared as an account of work sponsored by an agency of the United States Government. Neither the United States Government nor any agency thereof, or any of their emplovees, makes any warranty, expressed or implied, or assumes any legal liability of responsibility for any third party's use, or the results of such use, of any information, apparatus, product or process disclosed in this report, or represents that its use by such third party would not infringe privately owned rights.

\section{NOTICE}

Availability of Reference Materials Cited in NRC Publications

Most documents cited in NAC publications will be available from one of the following sources:

1. The NRC Public Document Room, 1717 H Street, N.W. Washington, DC 20555

2. The Superıntendent of Documents, U.S. Government Printing Otfice, Post Office Box 37082. Washington, DC 20013-7082

3. The National Technical Information Service, Springfield, VA 22161

Although the listing that follows represents the majority of documents cited in NRC publications, it is not intended to be exhaustive.

Referenced documents available for inspection and copying for a fee from the NRC Public Docu ment Room include NRC correspondence and internal NRC memoranda; NRC Office of Inspection and Enforcement bulletins, circulars, information notices, inspection and investigation notices: Licensee Event Reports; vendor reports and correspondence; Commission papers; and applicant and licensee documents and correspondence.

The following documents in the NUREG series are available for purchase from the GPO Sales Program: formal NRC staff and contractor reports, NRC-sponsored conference proceedings, and NRC booklets and brochures. Also available are Regulatory Guides, NRC regulations in the Code of Federal Regulations, and Nuclear Regulatory Commission /ssuances.

Documents available from the National Technical Information Service include NUREG series reports and technical reports prepared by other federal agencies and reports prepared by the Atomic Energy Commission, forerunner agency to the Nuclear Regulatory Commission.

Documents available from public and special technical libraries include all open literature items, such as books, journal and periodical articles, and transactions. Federal Register notices, federal and state legislation, and congressional reports can usually be obtained from these libraries.

Documents such as theses, dissertations, foreign reports and translations, and non-NRC conference proceedings are available for purchase from the organization sponsoring the publication cited.

Single copies of NRC draft reports are available free, to the extent of supply, upon written recjuest to the Division of Technical Information and Document Control, U.S. Nucledr Regulatory Com mission, Washington, DC 20555.

Copies of industry codes and standards used in a substantive manner in the NRC regulatory process are maintained at the NRC Library, 7920 Norfolk Avenue, Bethesda, Maryland, and are available there for reference use by the public. Codes and standards are usually copyrighted and may be purchased from the originating organization or, if they are American National Standards, from the American National Standards Institute, 1430 Broadway, New York, NY 10018. 


\section{NOTICE}

This report was prepared as an account of work sponsored by an agency of the United States Government Neither the United States Government nor any agency thereof, or any of their employees, makes any warranty, expressed or implied, or assumes any legal liability of re sponsibility for any third party's use, or the results of such use, of any information. apparatus. product or process disclosed in this report, or represents that its use by such third party would not infringe privately owned rights

\section{NOTICE}

Avallability of Reference Materials Cited in NRC Publications

Most documents cited in NRC publications will be avallable from one of the following sources

1 The NRC Public Document Room, 1717 H Street, N W Washıngton, DC 20555

2 The Superintendent of Documents, U S Government Printing Office, Pust Office Box 37082. Washıngton, DC 200137082

3 The Natıonal Technical Information Service, Sprıngfıeld, VA 22161

Although the listing that follows represents the majority of documents cited in NRC publications, it is not intended to be exhaustive

Referenced documents avalable for inspection and copying for a fee from the NRC Public Docu ment Room include NRC correspondence and internal NRC memoranda, NRC Office of Inspection and Enforcement bulletıns, circulars, information notices, inspection and investigation notices, Licensee Event Reports, vendor reports and correspondence, Commission papers, and applicant and licensee documents and correspondence

The following documents in the NUREG series are avallable for purchase from the GPO Sales Program formal NRC staff and contractor reports, NRC sponsored conference proceedings, and NRC booklets and brochures Also avalable are Regulatory Guides, NRC regulations in the Code of Federal Regulatıons, and Nuclear Regulatory Commission Issuances

Documents available from the National Technical Information Service include NUREG series reports and technical reports prepared by other federal agencies and reports prepared by the Atomic Energy Commission, forerunner agency to the Nuclear Regulatory Commission

Documents avalable from public and special technical libraries include all open literature items, such as books, journal and periodical artıcles, and transactions Federal Register notices, federal and state legislation, and congressional reports can usually be obtained from these libraries

Documents such as theses, dissertations, foreign reports and translations, and non NRC conference proceedings are avalable for purchase from the organization sponsoring the publication cited

Single copies of NRC draft reports are avalable free, to the extent of supply upon written recjuest to the Division of Technical Information and Document Control, U S Nucledr Requlatory Com mission, Washington, DC 20555

Copies of industry codes and standards used in a substantive manner in the NRC regulatory process are maintained at the NRC Library. 7920 Norfolk Avenue, Bethesda, Maryland, and are available there for reference use by the public Codes and standards are usually copyrighted and may be purchased from the originating organization or, if they are American National Standards, from the American National Standards Instıtute, 1430 Broadway, New York, NY 10018 


\section{Identification and Evaluation of Facilitation Techniques for Decommissioning Light Water Power Reactors}

Prepared by

T. S. LaGuardia, J. F. Risley

TLG Engineering, Inc.

640 Federal Road

Brookfield, CT 06804

\section{Prepared for}

Division of Engineering Technology

Office of Nuclear Regulatory Research

U.S. Nuclear Regulatory Commission

Washington, D.C. 20555

NRC FIN B8946 


\begin{abstract}
This report describes a study sponsored by the U.S. Nuclear Regulatory Commission to identify practical techniques to facilitate the decommissioning of nuclear power generating facilities. The objective of these "facilitation techniques" is to reduce the radioactive exposures and/or volumes of waste generated during the decommissioning process.

The report presents the possible facilitation techniques identified during the study and discusses the corresponding facilitation of the decommissioning process. Techniques are categorized by their applicability of being implemented during the three stages of power reactor life: design/construction, operation, or decommissioning. Detailed cost-benefit analyses were performed for each technique to determine the anticipated exposure and/or radioactive waste reduction; the estimated costs for implementing each technique were then calculated. Finally, these techniques were ranked by their effectiveness in facilitating the decommissioning process.

This study is a part of the Nuclear Regulatory Commission's evaluation of decommissioning policy and its modification of regulations pertaining to the decommissioning process. The findings can be used by the utilities in the planning and establishment of activities to ensure that all objectives of decommissioning will be achieved.
\end{abstract}




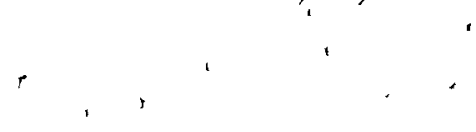


TABLE OF CONTENTS

Page

1. INTRODUCTION

1.1 Background

$1-1$

1.2 Objective

$1-1$

1.3 Scope

1.4 Organization of Report

$1-2$

1.5 References

$1-3$

$1-4$

2. GENERAL METHODS OF TECHNIQUE IDENTIFICATION AND EVALUATION

2.1 General Methodology and Approach 2-1

2.2 Identification and Categorization of Techniques 2-5

2.3 Safety/Feasibility Evaluation of Techniques 2-6

2.4 Disposition of Techniques

2.5 Analysis of Techniques Requiring Further Identification

2.6 Rating of Techniques

$2-9$

2.7 References

2-9

$2-11$

$2-11$

3. FACILITATION TECHNOLOGY IMPLEMENTED DURING DECOMMISSIONING

3.1 Introduction

3.2 Summary of Good Practice Techniques

3.3 Summary of Cost Benefit Analysis Techniques

3.4 Waste Compaction

3.5 Railcar Shipping Casks

3.6 Homogenization of Cask Shipments

3.7 Cask Liner Geometry

3.8 End of Life Decontamination

3.9 Incineration

3.10 Worker Training

3.11 On-Site Decontamination Facility

3.12 Explosive cutting of Piping and Components

3.13 Intact Removal

3.14 Rail and Barge shipment of NSSS Radioactive waste

3.15 Robotics/Automated Activities

3.16 References

\section{FACILITATION TECHNIQUES DURING OPERATIONS}

4.1 Introduction

4.2 Summary of Good Practice Techniques

4.3 Summary of cost Benefit Techniques 


\section{TABLE OF CONTENTS}

(Continued)

$\underline{\text { Page }}$

4.4 Comprehensive Data Base

$4-4$

4.5 Repassivation

$4-8$

4.6 Incineration

4.7 Preoperational Electropolishing

4.8 References

5. FACILITATION TECHNIQUES DURING DESIGN/CONSTRUCTION

5.1 Introduction

5.2 Summary of Good Practice Techniques

$5-1$

5.3 Summary of cost Benefit Techniques

$5-1$

$5-7$

5.4 Canal Gate

5.5 Containment of Liquids

$5-9$

$5-16$

5.6 Preplaced Blast Holes

$5-20$

5.7 Smooth and Coat Concrete Surfaces

5.8 Substitution and Purification of Materials

5.9 Modular Construction of the Bioshield

$5.1 \emptyset$ References

$5-23$

$5-26$

$5-31$

$5-4 \emptyset$

6. EVALUATION SUMMARY AND RANKING OF TECHNIQUES

6.1 Summary of Results

$6-1$

6.2 Results of Technique Ranking

$6-6$

\section{BIBLIOGRAPHY}

APPENDIX A List of Initial Facilitation Techniques for Consideration 
LIST OF FIGURES

$\underline{\text { Page }}$

2.1-1 Technique Evaluation Methodology and Flow Diagram 2-2

3.4-1 Typical waste Compactor 3-8

3.6-1a PWR Vessel - Segmentation Schematic 3-21

3.6-1b PWR Core Shroud - Segmentation Schematic 3-22

3.6-2a BWR Vessel - Segmentation Schematic 3-23

3.6-2b BWR Core shroud - Segmentation Schematic 3-24

$3.7-1$

$3 \cdot 9-1$

$3.11-1$

3.12-1

3. $13-1$

3.14-1 Schematic of Loaded Annular Sector Liner

Mobile Incinerator Conceptual Layout

Typical Decontamination Facility

Explosive Cutting of Pipe

Intact Removal of a steam Generator

Segmentation and Cask Loading Layout

$3-32$

$3-46$

$3-58$

$3-60$

$3-73$

$3-88$

4.7-1 Electropolishing the Interior of Long Pipe 4-19

5.4-1 Reference PWR Refueling Canal 5-10

5.4-2 Reference PWR with Canal Gate Modification During

Segmentation

5.9-1 Modular Biological shield:

a Keyed Block Configuration

Ring Configuration

Rectangular slab Configuration

Octagonal slab Configuration

$5-34$

$5-35$

$5-36$

5-37 


\section{LIST OF TABLES}

$\underline{\text { Page }}$

Summary Facilitation Techniques for Decommissioning Light Water Power Reactors

2.2-1 Dismantling Activities: Exposure \& Waste Volume

a PWR

b BWR

2.3-1 Safety/Feasibility Review Criteria

xvi i

$2-3$

$2-4$

$2-7$

$3.4-1$

Analysis: Waste Compaction

$3 \cdot 5-1$

Analysis: Railcar Shipping Cask

$3 \cdot 6-1$

Analysis: Homogenized Cask Shipment

Summary Table:

a Base Case

Facilitation Case

$\mathrm{b}$

$3 \cdot 6-3$

Summary Table: Base vs Facilitation Case

$3 \cdot 7-1$

$3 \cdot 7-2$

Specifications for Shielded Cylinder Shipping Casks

Conventional Cask Liner for PWR Vessel/Internals

Segments

$3 \cdot 7-3$

$3 \cdot 7-4$

Liner Geometry Configurations: Facilitation Case

Custom Designed Cask Liner for PWR Vessel/Internals

Segments

3. $7-5$

$3.8-1$

a

Cask Liner Geomet

b $\quad$ PWR

3.8-2 System Decontamination:

a PWR

b BWR

3.8-3 System Decontamination \& Removal:

a PWR

b BWR

$3.8-4$

$3.9-1$

Analysis: End of Life Decontamination

Disposal of Compacted Waste:

a Base Case

b Facilitation case

3.9-2 Incineration:

a PWR

b BWR

3.1ø-1 Program Elements:

a Exposure Reduction

b Waste Volume Reduction

3.11-1 Analysis: On-Site Decontamination Facility

3.12-1

Major Components, Piping systems and Occupational

Exposure: PWR Base Case

3.12-2 Component/Piping System Segmentation Techniques: PWR Base Case 


\section{LIST OF TABLES}

(Continued)

\begin{tabular}{|c|c|c|}
\hline $.12-3$ & Cutting of Selected Components/Piping: & \\
\hline a & PWR Base Case (Conventional Cutting) & $3-65$ \\
\hline $\mathrm{b}$ & PWR Facilitation Case (Explosive cutting) & \\
\hline $3.12-4$ & Analysis: Base Case vs Explosive Cutting Techniques & 68 \\
\hline $3.13-1$ & Analysis: Intact Removal & 75 \\
\hline $14-1$ & Limitations on NSSS Radwaste Using Truck Transport & -81 \\
\hline $4-2$ & Truck Shipment of NSSS Components: & \\
\hline a & PWR & $3-83$ \\
\hline b & BWR & \\
\hline $.14-3$ & Limitations on NSSS Radwaste Using Rail/Barge Transport: & \\
\hline a & 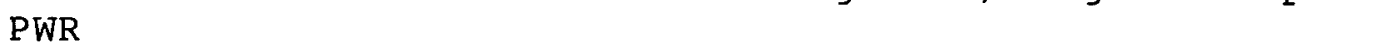 & $3-85$ \\
\hline $\mathrm{b}$ & BWR & 3. \\
\hline $3.14-4$ & Rail Shipment of NSSS Components: & \\
\hline a & PWR & $3-87$ \\
\hline b & BWR & -81 \\
\hline $.14-5$ & Barge Shipment of NSSS Components: & \\
\hline a & PWR & $3-9 \emptyset$ \\
\hline $\mathrm{b}$ & BWR & 96 \\
\hline$\cdot 14-6$ & Analysis: Rail/Barge shipment of NSSS Components & $3-91$ \\
\hline$\cdot 15-1$ & Base Case Drill and Spall Evaluation & 3 \\
\hline $.15-2$ & Analysis: Robots & .94 \\
\hline $4-1$ & Data Requirements of Decommissioning Planning & \\
\hline $.5-1$ & Analysis: Repassivation & $4-12$ \\
\hline $.6-1$ & Base Case Disposal of Compacted Waste & $4-15$ \\
\hline$\cdot 6-2$ & Facilitation Case Incineration of Waste from & \\
\hline & Operations & $4-16$ \\
\hline $.6-3$ & Incineration of DAW from Operations & $4-16$ \\
\hline $6-4$ & Incineration of Waste with an Existing Incinerator & $4-17$ \\
\hline $.7-1$ & Analysis: Preoperational Electropolishing & $4-22$ \\
\hline - 4-1 & Analysis: Canal Gate & $5-15$ \\
\hline $.5-1$ & $\begin{array}{l}\text { Design Improvements for Control/Containment of Liquid } \\
\text { Spilis }\end{array}$ & \\
\hline $5-2$ & Analysis: Control and Containment of Liquid Spills & $5-19$ \\
\hline . $6-1$ & Analysis: Preplaced Blast Holes & $5-22$ \\
\hline $5 \cdot 7-1$ & Analysis: Smooth and coat Concrete surfaces & $5-25$ \\
\hline $5.8-1$ & Analysis: Substitution and Purification of Materials & $5-30$ \\
\hline $5.9-1$ & As-Cast Bioshield Base Case. & $5-32$ \\
\hline $5 \cdot 9-2$ & Modular Bioshield Facilitation Case & $5-33$ \\
\hline & Analysis: Modular Bioshield & \\
\hline $\begin{array}{l}6.1-1 \\
6.1-2\end{array}$ & $\begin{array}{l}\text { Good Practice Technique Ratings } \\
\text { Quantitative Results of Facilitation Techniques }\end{array}$ & $6-2$ \\
\hline & Evaluated by Cost-Benefit Analyses & $6-4$ \\
\hline & Cost Benefit Technique Rankings & $6-7$ \\
\hline
\end{tabular}


FOREWORD

\title{
by \\ Nuclear Regulatory Commission
}

\begin{abstract}
On March 13, 1978 the Nuclear Regulatory Commission published an Advance Notice of proposed Rulemaking in the Federal Register stating that the Comission was re-evaluating its decommissioning policy and considering amendments to its reyulations to provide more specific requirements relating to the decommissioniny of nuclear facilities. The plan for the re-evaluation included the development of an information base and the development of proposed amendments to the regulations. This report, which prov des an assessinent of decommissioning facilitation techniques, forms part of the NRC's information base on decommissioning.
\end{abstract}




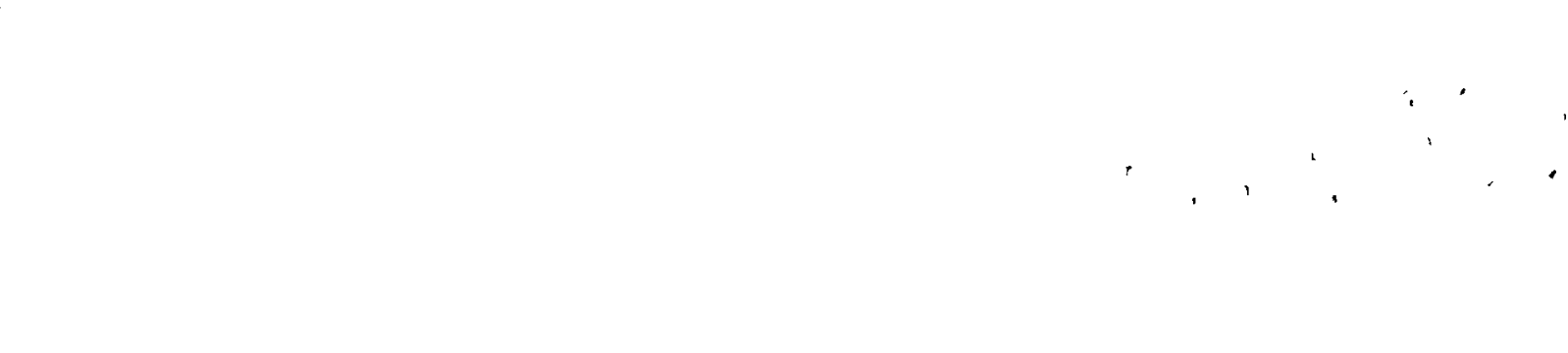

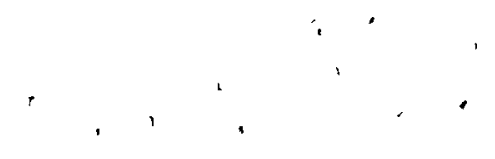

$-$

$\cdots$
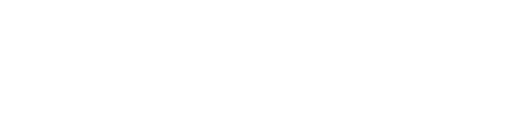

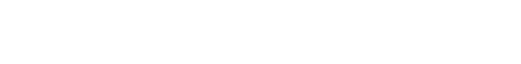




\section{ACKNOWLEDGMENTS}

The authors gratefully acknowledge the contribution of expertise from TLG staff engineers:

W. Cloutier

F. Seymore, P.E. Waste Management and Mechanical Engineering

E. Smith Nuclear Engineering Physics and Mechanical Engineering

J. Adler Health Physics and Radiological protection

The authors also thank the conscientious typing and editing of Kathleen Hubbard who devoted many hours to producing a quality, comprehensive manuscript.

The original concept for this study was developed by Don Calkins (retired) of the Nuclear Regulatory Commission. The objective and scope of the program were directed and reviewed by Frank Cardile of the Nuclear. Regulatory Commission. 
, 1,1, 


\section{SUMMARY}

Over the next forty years, the operating licenses of over one hundred commercial nuclear powered generating units will expire, leaving the owner utilities with the responsibility of ultimate disposition. The U.S. Nuclear Regulatory Commission (NRC) sponsored a study to identify practical techniques to facilitate the decommissioning of light water reactors in the United states. The study is part of the NRC's evaluation of its decommissioning policy and modification of regulations pertaining to the decommissioning process. This study is also intended for use by the utilities in the planning and establishment of activities to ensure that the full objectives of decommissioning will be achieved.

Facilitation of decommissioning is defined for this study as any controlled action to reduce occupational exposure and/or radioactive waste volume arising from decommissioning. The objective of this program is to provide practical recommendations to facilitate decommissioning operations while considering the implementation effects on plant design, operations, present technology, safety and costs in all phases of power plant life. Attention was given to identifying techniques addressing specific dismantling activities generating the greatest exposure and waste volume.

Techniques were identified using three major sources: industry solicitation, literature review and actual experience gained on previous decommissioning programs. Techniques were considered and identified for the three stages of plant life: design and construction, operation and decommissioning. All techniques were reviewed to pre-established standard criteria and reviewed for their safety/feasibility and practicality for implementation.

The techniques chosed included both direct and indirect techniques. Direct techniques are those that reduce occupational exposure or waste volume during the actual dismantling of a facility. Indirect techniques are those that can be implemented in the earlier phases of plant life and prevent and/or minimize both present and ultimate waste volume or occupational exposure. Therefore, the resulting techniques were categorized in the following three areas:

- activities directly applicable to reducing exposures and wastes during the dismantling process (decommissioning phase)

- plant operation/modification practices affecting "end- of-life" conditions in terms of potential exposures and waste generation (operations phase) 


$$
\begin{aligned}
& \text { - conceptual design and construction features to } \\
& \text { ultimately affect exposures and reductions in } \\
& \text { waste volume (design and construction phase) }
\end{aligned}
$$

\begin{abstract}
Early stages of the investigation produced a list of over one hundred potential facilitation techniques. of this initial grouping, many were combined under a common goal or technique, and many were ultimately rejected for a variety of cost, exposure, or implementation reasons. of the remaining group of viable techniques, most were then identified as "Good Practice" techniques, those that do not lend themselves to rigorous cost benefit evaluation yet will always provide some benefit in reducing exposures or waste volume. A smaller grouping of techniques required detailed cost benefit evaluation to actually determine and quantify the potential benefits. The Summary Table herein presents the categorical results of this study in that it delineates the most viable facilitation techniques for consideration at present and future stations. These techniques have been categorized as to general Good practice and those that required further cost Benefit studies.
\end{abstract}

The reference PWR and BWR stations identified in the NUREG/ $C R-\emptyset 13 \emptyset$ and NUREG/CR- 6672 reports prepared earlier for the NRC were used as the basis for evaluating each of the cost Benefit techniques. The quantitative results presented in this report are applicable to those stations and may vary when applied to specific sites. 


\section{FACILITATION TECHNIQUES FOR DECOMMISSIONING LIGHT WATER POWER REACTORS}

Decomaissioning Phase Radiological Characterization Segregation of Waste Magnets for Lifting Prior Removal of Clean component Urethane Foam/Spray Flxing Air Riltration/Pressure Gradients Segmenting under Negative Pressur Post-Activity Testing/Training with Mock Use of Site as Training Cente On-site Radiological Laboratory Mobile shielded Work stations Waste Compaction

Railcar shipping Casks Homogenization of Cask shipments Cask Liner Geometry End of Life Decontamination Incl neration

On-site Decon Facility

Explosive Cutting

Intact Removal

Rail/Barge Shipment

Robotics

Operations Phase

Comprehensive Data Base

Segregation of 011 Bearing waste

Maintain storage pools

Repassivation

Preoperational Electropolishing

Design Construction Phase Construction scale Models Remote Sampllng/Measuring Sealed Nonporous Insulation Enclosed Cable Trays Minimize Cable Trays in contaminated Areas

ocated Motor Control Centers Sufficient Waste Storage Capacity Bolted steel Construction Flanged Construction of Components Quick Disconnect Components Non-Embedment of Pipes in Concrete Removable Roof, Wall Panels/Plugs Access to and into all ranks plant Breathing Air Supply syste Pre-Installed Manipulator Support Lifting Lugs on Large Components Anchor Points for lifts

racks for Remote Cutting Devices Complete Drainage Capacity Canal Gate

Containment of Liquids Preplaced Blast Holes Smooth and coat Concrete Surfaces Substitute/Purify Materials
Modular Biological Shield ...to Identify/locate extent of contamination for ALARA planning ..to miniraize burial volume by controlled separation

...to minimize exposure when removing contaminated components

...to control cross-contamination during dismantling process

..of contaminated components to reduce exposure

...to control and limit spread of contamination

...to minimize airborne releases and subsequent contamination . to lncrease efrectlveness and reduce work the/exposures c. to reduce exposure during actual dismantling effort

pror practice

...to minimize exposure during removal activities

...of small bore piping, conduit, cable trays

...for shipment of radwaste to burial ground

..to optimizo NSSS packaging for transport/burial

...to optimize liner geometry/waste configuration

..of primary NSs systen

...of dry active radwaste during dismantling

...to reduce exposure during unique dismanting activities

ping and components in high radiation areas. ...of all radloactive waste to burial

...for removal of highly activated concrete

...to accurately record plant data necessary for decommissioning ..to reduce damage to waste handing systems

ng dismantling

..of decontaminated systems/components prior to return to service

... to minimize collection of radioactive crud in plant systems

...for clearances evaluation during removal of contaminated equipment ...to reduce exposure and improve time ef ficiency

...to reduce cable tray waste volume and incurred removal exposures

..to minimize subsequent volume of radwaste

...to reduce waste by minimizing potential equipment contamination

..to circumvent critical path items and facilitate

..to decrease exposures by eliminating contamination in dismantling

...to decrease exposure by remote or more efficient dismantiling

..to reduce exposure by allowing for remote segmentation

...to reduce removal and dismantling effort

...to improve access for removal of radioactive components

.. to allow for decontamination by water lancing or entry

...to increase worker efficiency and reduce time and exposures

..to provide contamination-free access for a port

.to reduce righing time and reduce exposires

.. to reduce exposure incurred in dismanting of activated components

...to minimize exposures during characterization of activated concrete

canal for segmentation

to minimize spread of contamination

$\because$ to minimize penetration of contamination

...to minimize vsss activation products

...to optimize removal of activated material

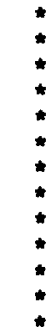

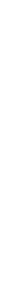




\section{INTRODUCTION}

All electric generating facilities must be retired from service and decommissioned at the end of their operating life. Over the next forty years the operating licenses of over one hundred commercial nuclear power plants will expire. The owner utilities will then bear the responsibility of disposition of the station and its radioactive elements. The objective of decommissioning is to retire a facility safely, economically, and with a minimum of radioactive exposure to both workers and the general environment. The decommissioning process includes the isolation and/or removal of radioactive materials. When decommissioned, the site can be released for unrestricted use either immediately or following decades of protected storage. Consequently, an important aspect of decommissioning is limiting radiation exposures and minimizing the total waste product during the dismantling process.

The "Draft Generic Environmental Impact statement on Decommissioning Nuclear Facilities" (Ref. 1-l) has indicated that an important aspect of planning for reactor decommissioning is to consider those techniques that minimize occupational or public exposure and/or radioactive waste volume. The supplementary information to the proposed rule, "Decommissioning Criteria for Nuclear Facilities," (Ref. 1-2, pg. 5606) recommends that the utilities identify the techniques they will use to facilitate the eventual decommissioning of each station.

The decommissioning process defined in Regulatory Guide 1.86, "Termination of Operating Licenses for Nuclear Reactors," (Ref. 1-3) addresses four decommissioning alternatives: Prompt Removal/Dismantling, Mothballing, Entombment and Conversion. The NRC's recently published proposed Rule on Decommissioning considers three major alternatives referred to as DECON, ENTOMB and SAFSTOR and defines them as follows:

DECON is the alternative in which the equipment, structures and portions of a facility and site containing radioactive contaminants are removed or decontaminated to a level that permits the property to be released for unrestricted use shortly after cessation of operations. 
SAFSTOR is the alternative in which the nuclear facility is placed and maintained in such condition that the nuclear facility can be safely stored and subsequently decontaminated (deferred decontamination) to levels that permit release for unrestricted use.

ENTOMB is the alternative in which radioactive contaminants are encased in a structurally long-lived material, such as concrete. The entombed structure is appropriately maintained and continued surveillance is carried out until the radioactivity decays to a level permitting unrestricted use of the property.

It should be noted that two of the accepted decommissioning alternatives, namely SAFSTOR and ENTOMB were developed with the objective of facilitating both short and long term decommissioning by allowing for the natural decay of radioactivity. As described in the NRC Proposed Rule, SAESTOR (for up to thirty years) will allow for the decay of cobalt 60 to very low levels, low enough to allow final decommissioning with reduced radiation exposures and less waste volume for ultimate disposal. Similarly, ENTOMB (for up to one hundred years) will allow both cobalt 60 and cesium 137 to decay to lower radioactivity levels, producing corresponding reductions in exposures and waste volume. These two facilitation techniques have been well described in NUREG/CR- $\emptyset 13 \emptyset$ and $-\emptyset 672$ reports and do not require further elaboration here.

\subsection{OBJECTIVE}

The objective of this study is to provide practical recommendations to facilitate the decommissioning of commercial light water power reactors by reducing radioactive exposures and waste volume. These facilitation techniques primarily address decommissioning but may be implemented during the design/construction or operations phase if they will benefit ultimate decommissioning. These recommendations identify the benefits while considering the implementation effects on plant design, operations, present technology, safety, costs, and final dismantling. In developing these recommendations, attention was given to identifying the specific activities of demolition and decontamination that incurred the most significant levels of exposures and waste volume during facility decommissioning. By identifying the most immediately practical of modifications, this report attempts to support the $\mathrm{NRC}$ in its continual reevaluation of decommissioning policy. 
This report can be used by utilities in their decommissioning planning in that it provides an overview of techniques for actual decommissioning. only sitespecific evaluation can determine the value of implementation. Taken in its entirety, however, this report identifies facilitation techniques and methods to expand and supplement existing alternatives for decommissioning and decontamination.

\subsection{SCOPE}

The scope of this study is limited to the decommissioning process as currently discussed in Regulatory Guide 1.86 and consequently only addresses those activities involved in the disposition of the radioactive materials/equipment of a light water reactor facility. Therefore, the investigation does not address such areas as routine building demolition or site restoration since these activities could take place after termination of an NRC 1 icense.

The facilitation techniques identified in this study are applicable to any of the three decommissioning alternatives provided in the NRC's proposed Rule. However, any detailed cost benefit analyses apply the techniques in terms of the DECON alternative. These techniques should be applicable to any commercial light water power reactors located in the united states; applicability to other nuclear facilities may be feasible but is not within the scope of this study.

The bases of evaluation for the majority of these facilitation techniques are the reference PWR of NUREG/CR- $\varnothing 13 \emptyset$ (Ref. 1-4) and reference BWR of NUREG/CR-ø672 (Ref. 1-5). Detailed evaluation of a technique for a specific station would best be determined on a case by case basis using specific plant parameters.

Methods currently practiced in operating stations to keep occupational exposures and waste volume to levels of "as low as reasonably achievable (ALARA)" are considered routinely applicable to decommissioning and not included here. The techniques evaluated in this study involve existing or conceptual methods specifically adapted for ultimate decommissioning.

\subsection{ORGANIZATION OF REPORT}

This report presents the results of the facilitation technique analyses as applied to reference PWR and BWR plants. Since these results may differ on a plant by plant basis, the report identifies the process used to 
establish a site-specific result for a standard station. Chapter 2 presents the methods of approach used to identify, evaluate and determine the benefits from the most effective of the facilitation techniques chosen for this report. Chapter 3 presents the detailed evaluation, assumptions and results of the analyses for those techniques to be applied during decommissioning. Chapters 4 and 5 present the same for those techniques applicable during the operations or design and construction phases, respectively. Chapter 6 provides a summary of the results of all evaluations. For those techniques with prepared cost benefit analyses, this chapter also presents a rank order in respect to exposure, waste and cost reductions.

Appendix $A$ is included as a complete list and disposition of all techniques considered in the initial evaluation. Those techniques that were ultimately rejected include brief summary of reasons for their elimination. This list should be of value to those attempting to identify the potential of alternative techniques in comparison with those chosen for this final report.

1-1 "Draft Generic Environmental Impact statement on Decommissioning," NUREG-6586, January, 1981.

1-2 Proposed Rule, "Decommissioning Criteria for Nuclear Facilities," Federal Register Vol. 50, No. 28 , pgs 56øø-5625, February 11, 1985.

1-3 Regulatory Guide 1.86, "Termination of Operating Licenses for Nuclear Reactors," June, 1974.

1-4 R. I. Smith, et al., "Technology Safety and Costs of Decommissioning a Reference Pressurized Water Reactor Power Station," NUREG/CR-ø13ø, June, 1978.

1-5 H. D. Oak, et al., "Technology Safety and costs of Decommissioning a Reference Boiling Water Reactor Power Station," NUREG/CR-ø672, June, $198 \emptyset$. 


\section{GENERAL METHODS OF TECHNIQUE IDENTIFICATION AND EVALUATION}

This chapter presents a description of the approach used to identify, evaluate and determine the benefits (exposure and waste volume reduction) presented in the results of the study. It should be noted that the quantitative study results presented in Chapters 3 through 5 are specific to the characteristics of the reference PWR and BWR and therefore may not be realized at a local station. As such, the following methodology is also intended to present an evaluation model that could be used for site-specific evaluations of techniques.

\subsection{GENERAL METHODOLOGY AND APPROACH}

The general method of approach for this study is presented in Figure 2.1-1, "Facilitation Technique Evaluation Program Methodology Flow Diagram." In general, the study involved four sequential phases, including:

\section{- Identification and Categorization of Techniques \\ - Safety/Feasibility Evaluation of Techniques \\ - Cost Benefit Analyses \\ - Rating of Facilitation Techniques}

The approach of the study was to focus on those dismantling activities that generated the greatest percentage of radiation exposure and wastes. Based on these activities, techniques were then identified that might well reduce exposure and/or waste volume when applied to major dismantling activities or routine maintenance operations.

Lists of major activities for dismantling power reactors associated with the immediate dismantling alternative (DECON) were developed for both pressurized and boiling water reactors. These lists were generated from decommissioning activity lists provided in the NUREG/CR- $\emptyset 13 \varnothing$ (hereinafter PWR study) and NUREG/CR- 0672 (hereinafter BWR study) studies (Refs. 2-1 and 2-2, respectively). Each activity from these studies was then examined in sufficient detail to identify the sources of exposure and types or general quantities of radwaste being generated. This effort provided a preliminary activity performance baseline and also identified areas where potential techniques could be applied.

Table 2.1-1(a\&b) reiterates those lists of dismantling activities presented in the PWR and BWR studies. These tables also include both the exposures and waste volume generated during each of the dismantling activities. As 
FIGURE $2.1-1$

\section{TECHNIQUE EVALUATION METHODOLOGY AND FLOW DIAGRAM}

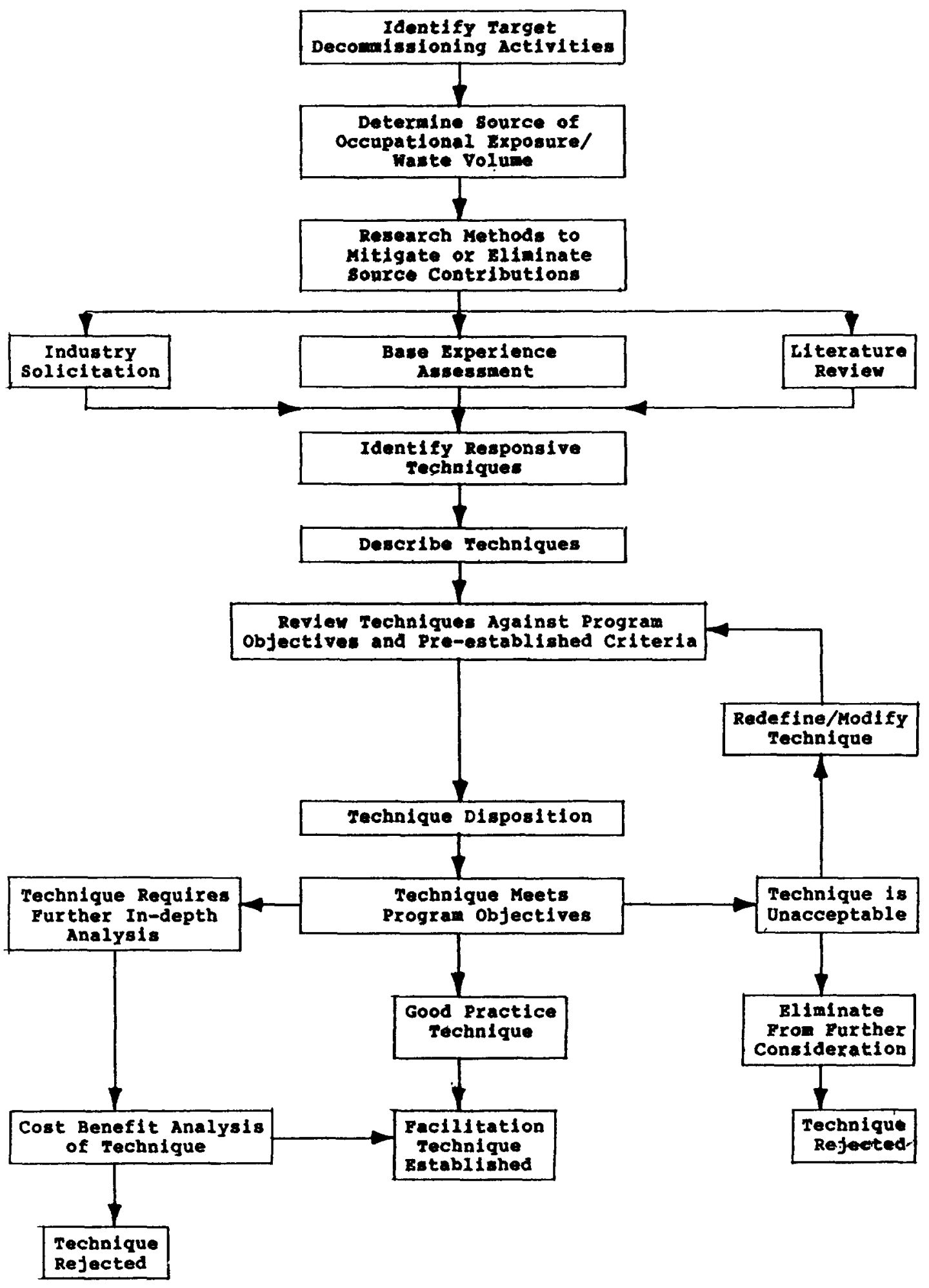

2-2 
TABLE 2.1-1(a)

PWR DISMANTLING ACTIVITIES: EXPOSURE \& WASTE VOLUME

(Reproduced from NUREG/CR-ø13ø, Vol. 2, Appendix G)

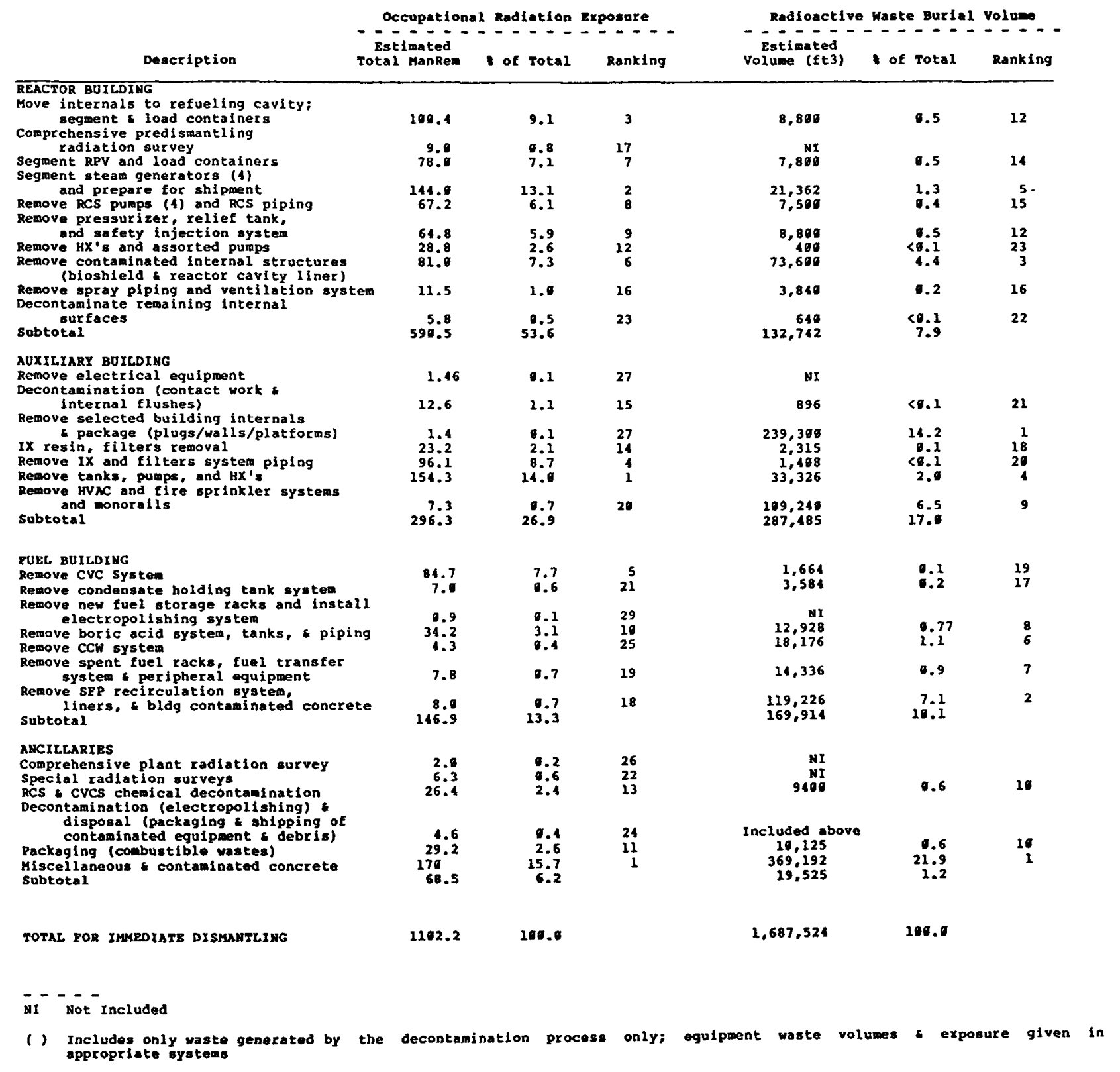


TABLE 2.1-1(b)

BWR DISMANTLING ACTIVITIES: EXPOSURE \& WASTE VOLUME (Reproduced from NUREG/CR-ø672, Vol. 2, Appendix I)

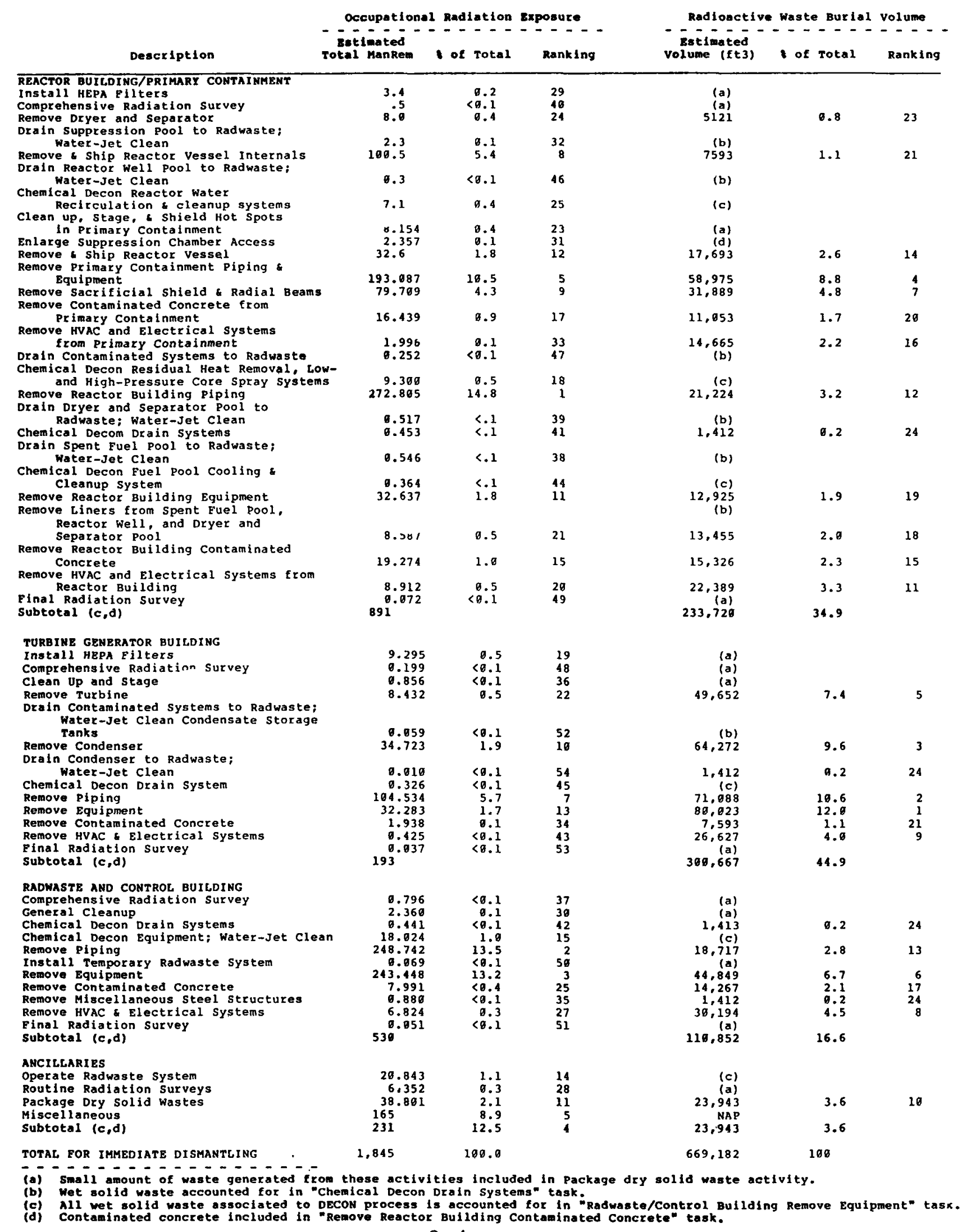


seen from these tables, the PWR's major dismantling activity generating the largest exposure and waste volume was the removal of contaminated concrete (Ancillary category). This activity contributed to approximately $15.7 \%$ and $21.9 \%$ of the total exposure and waste volume, respectively. For the BWR, the dismantling activity Removal of Reactor Building Piping generated the greatest exposure, while Remove Turbine Building Equipment generated the largest amount of waste. These two activities generated approximately $14.8 \%$ of exposure and $12 . \emptyset \frac{0}{6}$ of waste volume.

\subsection{IDENTIFICATION AND CATEGORIZATION OF TECHNIQUES}

Three methods were used to identify potential facilitation techniques. These included soliciting comments from the nuclear industry, performing a literature search, and reviewing consulting, testifying and on-site experience gained in past decommissioning projects.

Questionnaires were used to solicit comments from over 250 individuals representing a wide cross-section of nuclear and related industries. These individuals represented major utilities, major architect-engineers (A/ES), constructors, research and development facilities, and consulting organizations within the united States and Canada.

Additional techniques were identified by reviewing specific literature addressing the subject of decommissioning, including government or regulatory sponsored reports, published papers, conference proceedings, research reports, actual decommissioning project reports and other related public documents.

other potential techniques were developed by reviewing past decommissioning cost estimates, developmental programs, and technical specifications performed within the industry. One approach was to review planned specifications versus actual dismantling activities in past programs to determine if variations proved any marked benefits. Any techniques or practices producing exposure and/or waste reduction were identified and documented in the technique description package. Whenever data from a unique station was available, it served to enhance the benefits of the concept and establishe a relatively reliable reference source.

Techniques identified in these initial investigations had potential for implementation during any or all stages of plant life (design/construction, operation, and decommissioning) and would subsequently reduce exposures and wastes generated during actual decommissioning. 
Techniques were categorized as either direct or indirect techniques; direct techniques are those that reduce occupational exposure or waste volume during the actual dismantling of a facility. Indirect techniques are those that can be implemented in the earlier phases of plant life and prevent and/or minimize both present and ultimate waste volume or occupational exposure. Therefore, the resulting techniques were categorized in the following three areas:

- activities directly applicable to reducing exposures and wastes during the dismantling process (decommissioning phase)

- plant operation/modification practices affecting "end-of-life" conditions in terms of potential exposures and waste generation (operations phase)

- conceptual design and construction features to ultimately affect exposures and reductions in waste volume (design and construction phase)

The initial investigation produced a list of over one hundred techniques; these were then evaluated further for their feasibility, safety and contribution in reducing dose or waste volume.

SAFETY/EEASIBILITY EVALUATION OF TECHNIQUES

The objective of this effort was to evaluate each of the identified techniques with regard to safety, feasibility and assurance that the objective of each technique was consistent with the goals of the study. Implementing scenarios were developed to maximize the benefits of each technique in reducing exposures and wastes. This process clarified each technique and provided a baseline for a safety/feasibility review.

An assessment was performed of each technique to review its effect on safety, feasibility, and the practicality of implementation. Review criteria were formulated to standardize the evaluation of all identified techniques: a technique must not compromise any specific areas of each of these criterion. Table 2.3-1 presents a descriptive list of these review criteria.

Review of these areas provided a base for evaluation as to overall feasibility and practicality. Techniques failing these identified "Acceptibility Criteria" were not immediately rejected. An evaluation was first performed to determine if corrective action would alleviate or correct the concern. Based on these findings, a technique could be revised and the 
TABLE 2.3-1

SAFETY/FEASIBILITY REVIEW CRITERIA

Criteria Factors and Description

1 Industrial safety

Industrial safety (OSHA); fire and emergency evacuations; toxic/ radioactive inhalation; regulatory standards.

\section{$2 \quad$ Engineered Safeguards}

protection of safety functions of affected engineered safeguard systems.

3 Seismic Design (Seismic Category 1)

Components, systems and structures must be protected to ensure safe shutdown of the reactor during a design basis earthquake.

$4 \quad$ Pipe Whip Restraints

Engineered safeguard systems must be protected from adjacent high energy (high pressure, temperature) piping in the event of a pipe rupture; pipe whip restraints must not be removed or reduced in effectiveness.

\section{$5 \quad$ Redundancy of Components}

Engineered safeguard systems using redundant components as backup systems must not be removed, modified or reduced in effectiveness.

\section{Separation of Components}

Engineered safeguard systems protected by separation walls or space must not be connected or joined so as to bypass the separation design function.

\section{$7 \quad$ Postulated Accidents}

Facilitation techniques must not present potential accidents not previously evaluated, nor increase the severity of postulated scenarios prepared for plant Safety Analysis Reports required for an operating license. 
TABLE 2.3-1

(Continued)

\section{$8 \quad$ Security}

All required plant security procedures, systems and barriers must be maintained.

\section{$9 \quad$ Accessibility}

Interference with routine operation, preservice and inservice inspections, maintenance and repair functions must be avoided.

\section{Material Handling}

Technique cannon affect clearances or material size restrictions, or create obstructions, reduction in laydown space, rigging problems, or material removal rate reductions.

\section{Decontamination}

There shall be no loss or reduction in ability to decontaminate structures, systems or components.

\section{Durability}

There shall be no potential of degradation from radiation, temperature and humidity (normal operation and accidents).

\section{Material Compatibility}

There shall be no known effect of of any given substitution of materials on corrosion, surface finish, electrical conductivity, flammability or chemical reaction.

\section{Portability}

The feasibility for rapid installation and removal to perform maintenance, repair or ultimate removal shall be maintained.

\section{Component/Plant Capacity}

There shall be no effect on capacity of individual components or of the overall plant. 
evaluation process repeated until satisfactory or until further corrective action became impractical.

The safety/feasibility review of the technique served as the first factor for eliminating the nonviable techniques. An engineering evaluation of the remaining techniques would further eliminate any impractical techniques. Finally, techniques were objectively evaluated as to the practicality of their implementation. The guidelines of this engineering assessment were:

- There should be a relatively high potential for implementation of the technique (i.e., the decommissioning application should exist, a methodology identified, and the implementing technology be available.

- Techniques already recognized as standard industry practice should be consolidated into a general overview of known practices to enhance reductions in exposures and wastes, especially if at cost benefit.

- Techniques identified for a common application would be considered for potential consolidation and/or redefinition of objective or techniques.

2.4 DISPOSITION OF TECHNIQUES

Using the Acceptibility Criteria described in section 2.3, many of the initial techniques were eliminated for failing to meet any number of specific criteria. The remaining techniques were considered "Good practice" and were further examined in an attempt to quantify costs and benefits in terms of capital expense, radiation exposure, and waste volume.

Appendix A presents the disposition of each of the original techniques. When rejected, a brief explanation of the reason for rejection is included. on a plantspecific basis, these summaries may not be applicable and the techniques may be acceptable for possible use at a specific station.

These facilitation techniques were grouped into two categories: those being Good Practice techniques and those techniques supported by detailed cost benefit analyses. 
2.5.1 Good Practice Facilitation Techniques

These techniques provided some benefits when applied during reactor decommissioning, yet could not be quantified because of the generality of the technique. The assumptions made for each scenario could greatly affect the range of costs and benefits achieved so that the same results might not be reasonably reproduced in enough actual cases of decommissioning. However, engineering judgment indicated qualitative benefits if the technique were implemented. Chapters 3 through 5 identify and describe the benefits of those techniques considered to be Good Practice.

2.5.2 Facilitation Techniques Requiring Cost Benefit Analysis

"Cost Benefit" techniques required further evaluation to determine their viability. Preparation of detailed cost benefit analyses provided actual calculations for total waste volume of the proposed activities or approach. Additional data further quantified the capital expenses and occupational exposures.

Cost benefit analyses were performed by first identifying the two cases to be compared. These "base" and "facilitation" cases are defined as follows:

The Base Case represents normal practice and/or technique used in dismantling a nuclear station. These base case techniques have been used in previous decommissionings and therefore have some precedent for further application. For the sake of consistent standards, these cases are those established in the PNL NUREGs.

The Facilitation Case represents the application of the facilitation technique to the dismantling process. These cases are scenarios wherein the technique is applied to actual decommissioning to determine the savings in exposures, wastes, and subsequent capital expenses for obtaining those savings.

Cost benefit analyses considered both the base and facilitation case to evaluate exposure incurred and waste volume generated when applying either of these cases in decommissioning a facility. The benefits of the Cost Benefit techniques were then determined by comparing the results of the two cases. 
2.6 RATING OF TECHNIQUES

The techniques were rated by their potential savings and costs associated with those savings. The initial investigation produced a list of 108 potential techniques. of these, 63 were determined to be ones that would actually facilitate the decommissioning process. Specific and combined techniques within this group were then identified as Good practice, those not lending themselves to rigorous cost benefit evaluation but providing some benefit in reducing exposure or waste volume. The remaining techniques required that detailed cost benefit analyses be performed to determine and quantify their potential benefits. The reference PWR and BWR stations identified in NUREG/CR-Ø13ø (Ref. 2-1) and NUREG/CR- $\varnothing 672$ (Ref. 2-2) were used as the basis for evaluating each of the cost benefit facilitation techniques. The quantitative results presented in this report are applicable to those reference stations and may vary when applied to specific sites.

The Good Practice and cost Benefit techniques were ranked by determining their contribution to the reduction in overall exposure or waste volume associated with the decommissioning project. The rating table included in the summary of this report presents the ultimate techniques considered for this study, with a brief description and classification as to Good practice or cost Benefit. The cost Benefit techniques were later ranked with respect to their contribution in reducing overall exposures, waste volumes and costs associated with decommissioning the reference PWR and BWR stations.

2.7 REEERENCES

2-1 Smith, R.I., et al., "Technology, safety and Costs of Decommissioning a Reference pressurized water Reactor Power station," PNL, NUREG/CR-Ø13ø, 1978.

2-2 Oak, D.H., et al., "Technology, Safety and costs of Decommissioning a Reference Boiling Water Reactor Power station," PNL, NUREG/CR-ø672, $198 \emptyset$. 


\section{FACILITATION TECHNOLOGY IMPLEMENTED DURING DECOMMISSIONING}

3.1

\section{INTRODUCTION}

This chapter presents techniques to be implemented during the decommissioning phase of reactor life to reduce exposures and wastes. Twenty-five techniques are identified as applicable to either exposure or waste reduction. Thirteen of the techniques are considered to be Good practice and do not require detailed cost benefit analyses. These techniques will reduce exposures or waste if implemented at any type of reactor facility. The remaining techniques will also reduce exposure and/or waste volume but their benefits need to be quantified with respect to costs. For these latter techniques the benefits may be plant-specific.

\section{SUMMARY OF GOOD PRACTICE TECHNIQUES}

The techniques identified in this section are based on current technology or on logical projections of current technology. For the Good practice techniques, only the description of each is included herein. These techniques did not lend themselves to rigorous cost benefit analyses since the assumptions made for each scenario could greatly affect the range of costs and benefits achieved so that the same results might not be reasonably reproduced in actual decommissioning. Furthermore, if applied on a site-specific basis, the results might vary widely between plants. Nevertheless, the techniques would either reduce exposure or waste volume during decommissioning. These techniques were not ranked as to their relative merit since the benefits are likely to be plant or site-specific.

\begin{tabular}{ll}
\hline \multicolumn{1}{c}{ Technique } & Primary objective \\
$\begin{array}{l}\text { Radiological Characteriza- } \\
\text { Sion }\end{array}$ & Reduce exposure \\
$\begin{array}{l}\text { from Nonradioactive Wastes } \\
\text { Magnets for Lifting }\end{array}$ & Reduce waste volume \\
$\begin{array}{l}\text { Prior Removal of clean } \\
\text { Components }\end{array}$ & Reduce exposure \\
$\begin{array}{l}\text { Urethane Foam/Spray } \\
\text { Fixing of Contamination }\end{array}$ & Reduce exposure
\end{tabular}


Technique

Air Filtration/Pressure Gradients

Segment Components under Negative Pressure

On-Job Training of Work

Force

Post-Activity Debriefings

Testing and Training with Mockups

Use of Incompleted Nuclear Facility as Decommissioning Training Center

On-Site Radiological Laboratory

Mobile Shielded Work stations
Primary objective

Reduce waste volume

Reduce exposure

Reduce exposure

Reduce exposure

Reduce exposure

Reduce exposure

Reduce waste volume

Reduce exposure

Reduce exposure

Performance of a comprehensive radiological characterization prior to the start of decommissioning activities will reduce overall exposure incurred by the work force. The availability of such data in the planning phase allows for improved "as low as reasonably achievable" (ALARA) planning, explicit work activity definitions, comprehensive training programs, identification of support services requirements and better general scheduling. This technique will result in improved work efficiencies, decreased activity durations and significant savings in exposures.

Segregation of Radioactive waste from Nonradioactive waste

This technique reduces the waste volume requiring controlled disposal with a program designed to minimize the volume of clean material being removed and disposed of along with the contaminated component. The program requires comprehensive radiological characterizations to be performed in conjunction with a diligent and continuous monitoring effort by the HP staff. Workers should be indoctrinated as to the importance of selective removal and disposal of contaminated material. 
This technique is intended to reduce exposures incurred during the rigging phase of lightweight ( $<5$ tons) lifts by simplifying rigging requirements. Magnets could expedite movement of large quantities of contaminated and activated steel pipe and structural shapes and could reduce handling and worker exposures. However, access to the components with the main crane auxiliary hook might limit its use and therefore applicability. Additional care would be required to keep lifts close to the floor/grade in the event of a power failure or shift of load.

Prior Removal of Clean Components

This technique minimizes the quantity of clean material cross-contaminated by further activities. The removal of clean material prior to initiating such activities should be instituted in the planning phases of decommissioning and could be combined with improving area access for removal of activated/contaminated materials.

Urethane Foam/spray Fixing of Contamination

This technique minimizes the spread of contamination and associated exposures by fixing the contamination prior to removal of the host material. The technique is useful in cutting into a contaminated piping system boundary as part of the removal activity. The foam or spray coating injected around the cut area serves as an internal contamination control barrier, thus limiting release. The technique is cost effective in potentially high airborne particulate situations, provided the coating process does not incurr major exposures.

Air Filtration/Pressure Gradients

This technique involves the control of airflow by use of air curtains, pressure differentials and auxiliary ventilation systems to control and limit the spread of contamination. Air should be kept moving from low to high contamination areas. Use of negative pressure during activities generating airborne contaminants can restrict diffusion and allow capture on filters. The technique reduces exposure from inhalation and limits cross-contamination of building areas.

Segment Components Under Negative Pressure

This technique minimizes the release of contamination from potential breaching of contamination control tents 
by establishing the airflow from outside the boundary to the more highly contaminated inside. suction is established downstream of the component to be segmented, drawing air away from the worker toward the filtered suction port. These airflow controls decrease exposure from cutting operations.

On-Job-Training of Work Force

This technique will increase the effectiveness of the decommissioning work force, thus reducing work time, exposures and the possibility of an accident's spreading contamination. Whenever possible, decommissioning work should be scheduled such that an inexperienced workforce can first gain experience while working on noncontaminated or marginally contaminated systems. Actual decommissioning experience can be gained while producing effective work in a less radioactive environment. Additional discussion is included in section 3.10 because of the importance of this technique to decommissioning.

9 Post-Activity Debriefings

This technique will reduce exposures and inadvertent generation of radwaste. Newly acquired experience that could require better work planning and implementation techniques should be shared with other members of the decommissioning work force.

$1 \emptyset$ Testing and Training with Mockups

This technique reduces the exposure to the work force. The use of mockups to test techniques, train personnel and familiarize work crews to working conditions will reduce exposure time and allow the training of other ALARA practices.

11 Use of Incomplete Nuclear Facility as Decommissioning Training Center

This technique provides an opportunity to test and optimize operations, decommissioning techniques and their implementation to reduce exposures and wastes.

12 On-site Radiological Laboratory

This technique will facilitate radiological analyses of sample media (for the purpose of monitoring the success of decontamination activities) and prevent sampling activities from becoming critical path items, thereby reducing periods of nonproductive workforce time in 
potentially high exposure areas. A complete on-site radioanalytical laboratory will eliminate the long turnaround time normally associated with sending samples to outside laboratories.

13 Mobile shielded Work stations

This technique would limit worker exposure during maintenance and dismantling activities. This is accomplished by use of a mobile shield to reduce the working radiation levels and permit longer activity durations.

3. 3 SUMMARY OF COST BENEFIT TECHNIQUES

For the remaining facilitation techniques, the basic assumptions are identified and the method of analyses described so as to be useful in evaluating the applicability of the technique on a case by case basis. Each technique was compared to a base case taken from current practice or from the reference PWR (Ref. 3-1) or BWR study (Ref. 3-2). Only those techniques that provided reductions in exposure and/or waste volume, irrespective of cost, were included as potential facilitation techniques. A technique that reduced exposure but increased waste volume at greater cost than the base case was considered potentially viable.

As operating reactors near their end of operational life, site-specific evaluations may show the applicability of these techniques for a specific plant. A sitespecific analysis may show the costs to be the same or lower than the base case and therefore more cost effective. In some cases, the benefit of a technique is improved if it is implemented during the operations or design/construction phase. These dual benefit techniques will be identified in the appropriate conclusions section of each technique description. The facilitation techniques evaluated by cost-benefit for the decommissioning phase of reactor life are as follows :

Technique

Waste Compaction

Railcar Shipping Casks

Homogenization of

Cask Shipments

Cask Liner Geometry
Primary objective

Reduce waste volume

Reduce waste volume

Reduce waste volume

Reduce waste volume 
Technique

End of Life Decontamination

Incineration

Worker Training

On-site Decontamination

Facility

Explosive Cutting

Intact Removal

Rail/Barge Shipment

Robotics
Primary objective

Reduce exposure

Reduce waste volume

Reduce exposure

Reduce waste volume

Reduce exposure

Reduce exposure

Reduce exposure

Reduce exposure

Evaluation of techniques involving disposal of highly activated reactor vessel internals indicated portions of the internals may require shipment to a deep geological repository. Since federal repository costs have not been established, current LLW disposal costs were used. 
3.4 'WASTE COMPACTION

3.4.1 Description

This technique was identified to effectively decrease the wastes associated with contaminated small bore piping, cable trays and conduit. Compaction, using commercially available waste compactors, was evaluated as for its potential cost benefit. Figure 3.4-1 shows a typical waste compactor.

3.4.2 objective

The purpose of this cost benefit analysis was to determine the reduction in net wastes, exposure and cost associated with the disposition of low specific activity (LSA) waste. Compaction of wastes prior to packaging should minimize the number of containers required and the resultant burial volume.

3.4.3 Approach and Methodology

The analysis addressed the activities to prepare LSA waste for disposal with and without compaction. The type of waste included small bore piping $\leq 6$ " dia., Schedule $4 \varnothing$ maximum), electrical conduit and cable trays. Compaction was performed on-site using a dedicated work force and currently available compactors.

The crushing/compacting equipment considered is currently available to the nuclear industry and is capable of handling the items 1 isted above.

3.4.4 Cost Benefit Analysis

3.4.4.1 Assumptions

1 Components considered in this study are ventilation ducts, cable trays, small pipe ( $\leq 6 "$ dia., Schedule $4 \emptyset$ maximum or an average 3" dia.), I" dia. electrical conduit.

2 Dose rates from waste packages are assumed to be at the maximum available DOT 49 CFR 173-178 limits (Ref. 3-3).

3 Waste disposal fees of $\$ 36$ per cubic foot of waste are used. This fee includes container cost, transportation fee and burial ground fees.

4 Assumed labor rate for compactor/crusher operators is that of a "standard light equipment operator." 
FIGURE 3.4-1

TYPICAL WASTE COMPACTOR

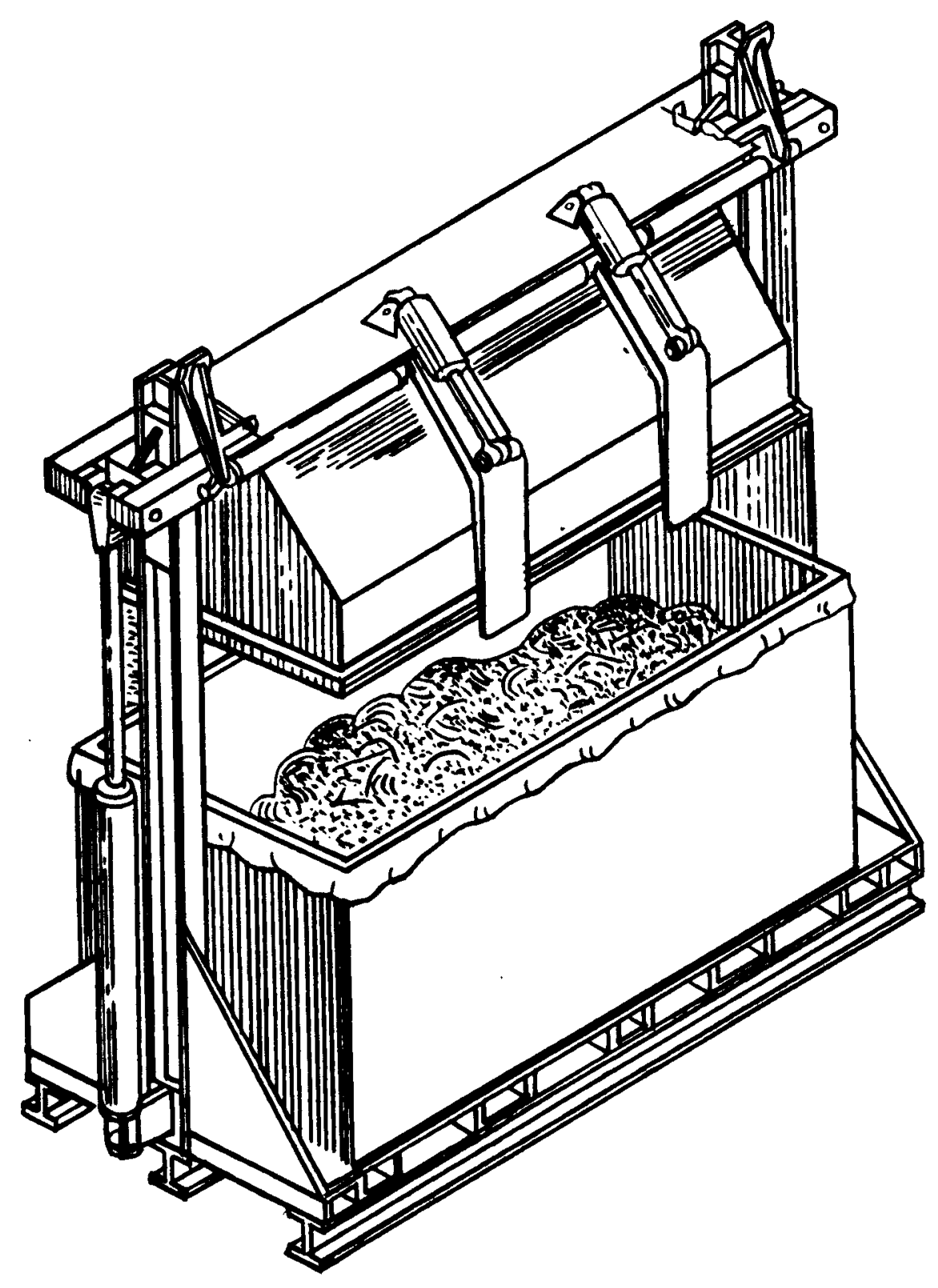


5 All work performed is assumed to be done by a subcontractor and therefore a contractor overhead and profit factor of 1.6 is applied to all labor and material costs (Ref. 3-4).

6 Cables are removed from conduit for salvage. Cables are not removed from cable trays since the trays are not sealed, thereby allowing the cables to become contaminated. It is assumed that cables occupy $1 / 3$ of the internal. volume of a tray.

\subsubsection{Base Case}

The total volume of contaminated small bore piping (not greater than 6" dia.), cable trays, and conduit was calculated based on total lengths of this material. The total small pipe length was $682,5 \emptyset \emptyset$ feet and resulted in a volume of $34,125 \mathrm{cu} f t$. The total cable tray length was $14, \emptyset \emptyset \emptyset$ feet and yielded a volume of $14, \emptyset \emptyset \emptyset$ cu ft. The total length of conduit was $97,50 \emptyset$ feet and resulted in a volume of 536 cu ft. This leads to a base case total volume of 59,475 cu ft when loaded in a $9 \emptyset$ cubic foot capacity LSA box with a 110 cubic foot burial (outer) volume (approximately 540 boxes).

The personnel exposure is predicated on an average work area radiation field of $10 \mathrm{mR} / \mathrm{hr}$. The total labor required is $2,43 \emptyset$ manhours to package and $27 \emptyset$ manhours to survey, label and load the noncompacted waste. This results in 24.3 manRem of exposure.

The manpower costs associated with packaging 540 LSA boxes is $\$ 88,960$. The health physics survey, labeling and truck loading costs resulted in a cost of $\$ 11,125$, yielding a total manpower cost of $\$ 1 \emptyset \emptyset, \emptyset 85$ for the noncompacted or base case. The waste disposal costs associated with this case are $\$ 2,138,40 \emptyset$ ( $54 \emptyset$ boxes, $11 \emptyset$ cu ft per box, $\$ 36$ per cubic foot of waste). The total cost for the base case is therefore approximately $\$ 2,238,485$.

3.4.4.3 Facilitation Case

Based on the cross-sectioned geometries of the waste forms and waste compactor characteristics, it was determined that compacting the original $34,125 \mathrm{cu} f t$ of small pipe would result in $10,238 \mathrm{cu} f t$ of compacted volume. Similarly, the $14, \emptyset \emptyset \emptyset$ cu ft and $536 \mathrm{cu}$ ft of cable trays and conduit, respectively, would be reduced to 4,667 and $97.5 \mathrm{cu} f t$. This leads to a total compacted waste volume (including $173 \mathrm{LSA}$ boxes) of $19, \emptyset \emptyset \emptyset \mathrm{cu} f t$ when including the volume of the disassembled contaminated waste compactor system. 
The personnel exposure associated with the facilitation case is also based on a work area radiation field of $1 \varnothing$ $\mathrm{mR} / \mathrm{hr}$. The total manhour expenditure is 939 manhours and includes compactor system operation (692 manhours) and dismantlement ( 160 manhours), and the surveying, labeling and loading (87 manhours) of the compacted waste containers. This yields 9.4 manRem for the facilitation case exposure.

The cost of the facilitation case includes equipment (capital), manpower and waste disposal costs. The total capital investment would be $\$ 220, \emptyset \emptyset \emptyset$ (Ref. 3-4) and

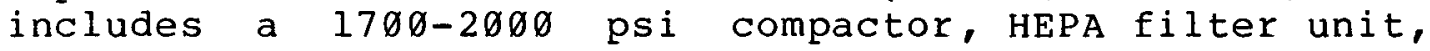
hydraulic system and control panel. The manpower related costs are $\$ 28,480$ for waste compactor system operation, $\$ 6,592$ for compactor dismantlement, and $\$ 3,568$ for HP survey, labeling and loading of LSA boxes. The waste disposal cost associated with this case is $\$ 685, \emptyset 80$ (173 boxes, 110 cu ft per box, $\$ 36$ per cubic foot). Consequently, the total facilitation case cost is $\$ 943,720$.

3.4.5 Conclusions

The cost benefit analysis yielded significant facilitation case savings in all three evaluation categories. First, a reduction of over $4 \emptyset, \emptyset \emptyset \emptyset \mathrm{cu}$ ft of waste burial volume was realized. Second, the facilitation activity was performed with less exposure ( 9.4 vs 24.3 manRem) to the total work crews as a result of automation and reduced waste handling. Finally, the total implementation cost was reduced by more than $\$ 1.25$ million. With the rising costs of waste disposal and the decrease in available burial space, this technique will become increasingly valuable. These results are summarized in Table 3.4-1.

TABLE 3.4-1

ANALYSIS: WASTE COMPACTION

$\begin{array}{ccccc}\text { Evaluation } & \text { Base } & \text { Facilitation } & \text { Net } & \text { Percent } \\ \text { Category } & \text { Case } & \text { Case } & \text { Reduction } & \text { Reduction }\end{array}$

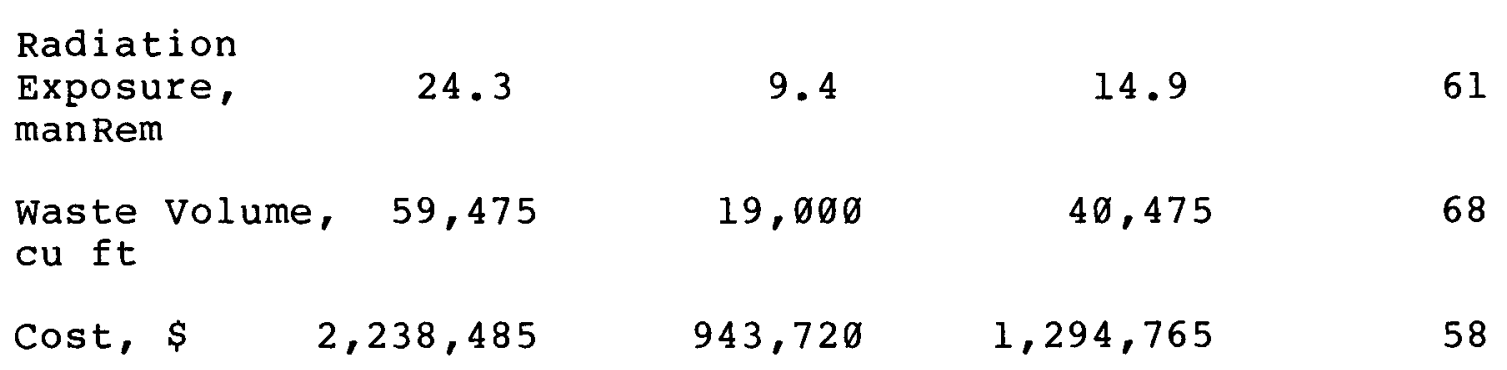




\subsection{RAILCAR SHIPPING CASKS}

3.5.1 Description

This technique was identified to assess the use of railcar shipping casks for transporting highly activated reactor components to a burial facility. Currently, truck transported casks are used to evaluate the burial of the core shroud, lower core barrel, upper core plate, and lower core plate. The relatively small weight and curie capacities of these truck casks create inefficient packaging conditions. The use of railcar casks may increase the packaging efficiency and result in a smaller burial volume for the highly activated components.

3.5.2 Objective

The purpose of this cost benefit analysis is to determine if railcar casks can reduce the net wastes, exposure and cost associated with the disposition of the core shroud, lower core barrel, upper and lower core plate.

3.5.3 Approach and Methodology

The analysis evaluated the activities to dispose of the core shroud, lower core barrel, and upper and lower core plates. The radioactivity source terms for these components were based on the levels at two years after shutdown. The two year delay is the time postulated before any reactor vessel internals will be shipped. This information, along with component weights, shipping cask/vehicle data and burial facility fees, was used to determine the number of shipments, burial volumes, and costs for the different scenarios. The casks analyzed were the CNS-3-55 (Vandenburg truck cask), and the IF-3øø railcar shipping cask. The vessel internals described for the PWR study (Ref. 3-1) were used as the basis for determining the variations in disposal volume and cost.

The core shroud curie concentrations of Ni-63 will likely exceed 10CFR61 (Ref. 3-5) Class C limits and may not be routinely acceptable for near-surface disposal. Methods such as dedicated slit trenches at LLW facilities or disposal at federal repositories may be required. However, because this radionuclide is an activation product bound within the stainless steel alloy and is non-dispersible, the disposal by burial in a dedicated slit-trench in an LLW burial facility is feasible. To be sure, the disposal would have to be evaluated for its safety and its environmental 
considerations, including handling requirements,' dose assessment, corrosion rate and leachability. However, irrespective of the burial location, homogenized cask shipments would provide more efficient use of the burial site and hence lower overall disposal cost. Since federal repository disposal costs have not been established, current LLW disposal costs were used. Accordingly, for this cost benefit analysis and all subsequent analyses addressing disposal of the core shroud, it will be assumed that disposal by LLW burial is permissible. The special costs for such dedicated trench burial have been included in the cost benefit analysis.

\subsubsection{Cost Benefit Analysis}

\subsubsection{Assumptions}

1 The reactor vessel internals used as the basis for this cost benefit analysis are PWR internals as described in the PWR study (Ref. 3-1)

2 The curie contents are based on two year decay after plant shutdown, the assumed time of shipment for the vessel internals.

3 Dose rates from waste packages are assumed to be at the maximum allowable DOT limits (Ref. 3-3).

4 Waste disposal fees are based on 1984 Chem-Nuclear burial facility rates (Ref. 3-7).

5 The results observed for the PWR vessel internals are similar to those for the BWR vessel internals due to similarities in neutron flux, construction materials, location, and base case model.

6 The exposure variations between the base and facilitation case are assumed to be negligible. Although the option of fewer shipments should result in less total exposure due to fewer handling operations, this difference is minimal when compared to the exposures associated with segmentation and loading operations. For this analysis such differences can be ignored.

7 The waste materials contain no residual chelates that may have been used in decontamination.

8 The burial facility will waive waste volume monthly quotas for this one-time decommissioning shipment from the nuclear power plant. These onetime waivers are permissible for dedicated slit-trench burial. 
The low-level waste (LLW)

burial site will permit the core shroud to be disposed of in a dedicated slit-trench.

\subsubsection{Base Case}

The Vandenburg (CNS 3-55) truck cask has an effective burial volume of $68 \mathrm{cu} f t$ with total radioactive materials not to exceed $47,14 \emptyset$ curies and total payload weight not to exceed 9,222 pounds. These curie and payload capacities are used with PWR reactor internals' characteristics at two years after shutdown to determine the required number of truck shipments and, therefore, the burial waste volume and related costs.

The core shroud contains approximately 1.99 million curies and weighs $27, \emptyset \emptyset \emptyset$ lbs. It will require at least 41 shipments due to curie limitations and results in 2,788 cu ft of waste. The lower core barrel contains $376,00 \emptyset$ curies and weighs $59,0 \emptyset \emptyset$ lbs. It will require 8 curie limited shipments and will create $544 \mathrm{cu} f t$ of waste volume. The upper core plate contains 13,7øø curies and weighs $10,18 \emptyset$ lbs. It will require two Vandenburg cask shipments (weight limited) and result in approximately $136 \mathrm{cu}$ ft of waste. Finally, the lower core plate contains $312, \emptyset \emptyset \emptyset$ curies and weighs 8,681 lbs. It will require 7 curie limited shipments for complete disposal, resulting in $476 \mathrm{cu}$ ft of burial volume.

Costs for the base case were determined using 1984 Chem-Nuclear burial facility rates and other burial information provided by Chem-Nuclear in conjunction with the shipping data discussed above. This analysis showed that disposal costs for the core shroud totaled $\$ 5,761,320$. The lower core barrel transportation and disposal costs were $\$ 1,126,208$; the upper core plate cost was $\$ 250,832$ and the lower core plate cost was approximately $\$ 983,640$.

Shipment of the PWR core shroud, lower core barrel, and upper and lower core plates requires a total of 58 Vandenburg cask shipments. The resulting burial volume from these shipments will be approximately $4000 \mathrm{cu} f t$, and the total container, transportation, and disposal cost for the base case will be $\$ 8,122, \emptyset \emptyset \emptyset$.

\subsubsection{Facilitation Case}

The IF-3øø railcar shipping cask has an effective payload volumetric capacity of $115 \mathrm{cu}$ ft (37.5" dia. $x$ 18ø"). The radioactivity and weight limitations for this cask are 2.4 miliion curies and $21, \emptyset \emptyset \emptyset$ lbs. The number of shipments, burial volume and associated costs 
were determined using this shipping cask information along with the detailed PWR reactor internals data presented in the PWR study (with curie content decayed to two years after shutdown).

For this case, the core shroud (1.99 million curies and $27, \emptyset \emptyset \emptyset$ lbs) will require only two shipments, with weight being the dominant factor. This will result in $23 \emptyset$ cu ft of waste. The lower core barrel $(376, \emptyset \emptyset \emptyset$ curies and $59, \emptyset \emptyset \emptyset$ lbs) can be disposed of in four shipments with weight again being the limiting condition. These four shipments will produce $460 \mathrm{cu} f t$ of waste. The upper core plate $(13,7 \emptyset \emptyset$ curies and $1 \emptyset, 18 \emptyset$ lbs $)$ can be transported in a single shipment (115 $\mathrm{cu} f t)$ since neither the curie nor the weight limits of the railcar cask will be exceeded. The lower core plate $(312, \varnothing \varnothing \emptyset$ curies and 8,681 lbs) can also be disposed of in one shipment, creating only 115 cu ft of disposal volume.

Based on the above disposal conditions, as well as burial facility data, the costs for liners, transportation and burial were calculated for the railcar shipping cask. The core shroud disposal cost was $\$ 572,398$, the lower core barrel was $\$ 1,144,796$ and both the upper and lower core plates were $\$ 286,199$.

In summary, only eight shipments will be required to dispose of the vessel core shroud, lower core barrel,

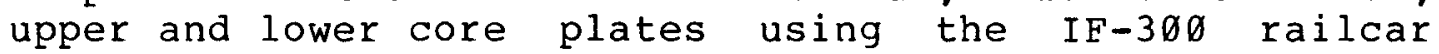
cask. This is approximately $920 \mathrm{cu} f t$ of waste, based on $115 \mathrm{cu}$ ft per shipment. The total cost associated with this facilitation case is $\$ 2,289,592$.

3.5.5 Conclusions

The cost benefit analysis yielded significant facilitation case savings in both evaluation categories, as summarized in Table 3.5-1. A 77\% reduction in waste was realized by implementing the facilitation case. This $308 \emptyset \mathrm{cu}$ ft waste reduction, along with the decrease in the number of shipments, lead to a cost savings of nearly $\$ 6$ million. Implementation of the facilitation technique will significantly reduce waste and cost. 
TABLE $3 \cdot 5-1$

\section{ANALYSIS: RAILCAR SHIPPING CASK}

\begin{tabular}{lcccc}
$\begin{array}{l}\text { Evaluation } \\
\text { Category }\end{array}$ & $\begin{array}{c}\text { Base } \\
\text { Case }\end{array}$ & $\begin{array}{c}\text { Facilitation } \\
\text { Case }\end{array}$ & $\begin{array}{c}\text { Net } \\
\text { Reduction }\end{array}$ & $\begin{array}{c}\text { Percent } \\
\text { Reduction }\end{array}$ \\
\hline $\begin{array}{l}\text { Waste Volume, } \\
\text { cuft }\end{array}$ & $4 \emptyset \emptyset \emptyset$ & $92 \emptyset$ & $3 \emptyset 8 \emptyset$ & 77 \\
Cost, $\$$ & $8,122, \emptyset \emptyset \emptyset$ & $2,289,592$ & $5,832,4 \emptyset 8$ & 72
\end{tabular}


3.6 HOMOGENIZATION OF CASK SHIPMENTS

3.6.1 Description

This technique of maximizing shipping cask packing efficiency was evaluated as a viable means of reducing the number of cask shipments required during a decommissioning project.

3.6.2 Objective

The objective of this cost benefit analysis is to determine the reduction in wastes, exposure and cost associated with the disposition of activated segments of PWR and BWR vessel and internal components by maximizing shipping cask liner volumes. This study considered the optimization of these liners with respect to allowable transportation weight and curie limits.

3.6.3 Approach and Methodology

The analysis addressed homogenization of vessel and internal segments so as to ship casks to both their curie and weight capacities. The present approach requires two types of cask shipments. Those shipments made to the curie limits of the transportation cask and/ or handling capacity of the burial ground would be composed of relatively light/thin highly activated segments of the reactor internals. Those shipments limited by the payload/vehicle road weight limits would be composed of massive but less activated vessel shell segments.

The method of approach involved the following sequence of activities:

- Using reference $11 \emptyset \emptyset$ MWe PWR and BWR reactor systems, identify the weight and curie content of each vessel and internal component

- Develop base cases for curie limited and weight limited activated component cask shipments

- Identify parameters for study including shipping cask limitations, U.S. DOT regulations and burial restrictions

- Develop facilitation cases considering homogenized vessel/internals segments in selected shipping casks

- Perform detailed segmentation analysis to determine optimum configurations within casks 
- Calculate exposure, wastes and costs associated with each case

\subsubsection{Cost Benefit Analysis}

\subsubsection{Assumptions}

1 The PWR and BWR reactors presented in the reference studies (Refs. $3-1 \& 3-2$ ) are the basis for the standard $11 \emptyset \emptyset$ MWe stations.

2 Commercially available shipping casks are used for both the base case and facilitation technique evaluations.

3 Weight and curie limits are used as stated in the cask license, U.S. DOT and commercial burial facility requirements (Refs. $3-3 \& 3-6$ ).

4 One-way shipping distances are assumed to be $5 \emptyset \emptyset$ miles with transportation fees, as stated in Tri-State Motor Transit Rate Schedule (Ref. 3-8).

5 Burial rates and guidelines are taken from chemNuclear Systems, Inc. 1984 burial rate schedule (Ref. 3-7).

6 Unit factors cost for PWR and BWR segmentation labor and handling are taken from the AIF/NESP- $\emptyset 9$ Report (Ref. 3-9) and escalated at a rate of $6 \%$ a year.

7 The waste materials contain no residual chelates that may have been used in decontamination.

8 The burial facility will waive waste volume monthly quotas for this one-time decommissioning shipment from the nuclear power plant. These one-time waivers are permissible for dedicated slit-trench burial. Examples include st. Lucie and Millstone II inner thermal shield disposals.

9 The low-level waste (LLW) burial site will permit the core shroud to be disposed of in a dedicated slit-trench.

\subsubsection{Base Case}

The PWR and BWR studies were used as the basis for the comparison. These reports provided detailed information on reactor vessel and component weight, volume and estimated radioactivity inventories. The radioactivity levels provided were adjusted to account for a two-year delay between plant shutdown and reactor dismantling. The analysis also considered only the homogenization of 
the reactor vessel and core shroud since these are the major contributors to overall weight and radioactivity. Table 3.6-1 is a summary of the base case parameters used in this analysis:

TABLE $3.6-1$

\section{ANALYSIS: HOMOGENIZED CASK SHIPMENT}

\begin{tabular}{|c|c|c|c|}
\hline Component & $\begin{array}{l}\text { Weight } \\
\text { (libs) }\end{array}$ & $\begin{array}{l}\text { Estimated } \\
\text { Activity } \\
\quad \text { (Ci) }\end{array}$ & $\begin{array}{l}\text { Activity After } \\
\text { 2-year Delay } \\
\text { (Ci) }\end{array}$ \\
\hline $\begin{array}{l}\text { PWR } \\
\text { Pressure Vessel } \\
\text { Core Shroud }\end{array}$ & $\begin{array}{r}594,8 \emptyset \emptyset \\
27,1 \emptyset \emptyset\end{array}$ & $\begin{array}{r}18,246 \\
3, \emptyset 61, \emptyset \emptyset \emptyset\end{array}$ & $\begin{array}{r}1 \emptyset, 472 \\
1,9 \emptyset 5, \emptyset \emptyset \emptyset\end{array}$ \\
\hline $\begin{array}{l}\text { BWR } \\
\text { Reactor Vessel } \\
\text { Core Shroud }\end{array}$ & $\begin{array}{r}1,450,50 \emptyset \\
64,9 \emptyset \emptyset\end{array}$ & $\begin{array}{r}2,160 \\
6,30 \emptyset, \emptyset \emptyset \emptyset\end{array}$ & $\begin{array}{r}1,24 \emptyset \\
4, \emptyset 63, \emptyset \emptyset \emptyset\end{array}$ \\
\hline
\end{tabular}

The segmenting, packaging and shipping scenario used for the base case was consistent with that presented in the AIF/NESP- $\emptyset 9$ study. This study assumes that the reactor vessel will be segmented on the basis of cask weight limits and the core shroud on the basis of cask curie limits. The segmented pieces of the beltiine region of the vessel or internals are packaged in disposable liners and trucked to burial in commercially available casks. The casks considered in the analysis included the CNS 8-120 cask (Ref. 3-10) and Vandenburg cask (Ref. 3-11). The CNS 8-12ø cask provides a large net payload $(2 \emptyset, \emptyset \emptyset \emptyset$ lbs.) but smaller allowable curie content (approximately $3 \emptyset \emptyset$ curies). This cask would be used for shipping the BWR vessel components because of their relatively low curie levels ( $<13$ curies per shipment).

The Vandenburg cask was used for shipment of both PWR and BWR core shrouds and PWR vessel segments. This cask has an allowable maximum net payload of $90 \emptyset \emptyset$ pounds and an activity limit of $47,1 \emptyset \emptyset$ curies. Both casks meet U.S. DOT requirements for the net weight and curie limit specified in their licenses. The base case results presented in Table 3.6-1 were developed using the aforementioned assumptions.

\subsubsection{Facilitation Case}

The facilitation case considered mixing the segments of the vessel and core shroud to maximize the use of both curie and weight capacities of the transportation casks. 
The analysis used both the CNS 8-12ø and Vandenburg casks to maximize packaging efficiency. These maximized packaging configurations are presented in Figures 3.6-1 $(a \& b)$ and 3.6-2(a\&b) for the PWR and BWR cases, respectively. The analysis assumed that sufficient storage capacity was available in the vessel/internals segmentation area to store activated segments while arranging complete homogenized shipments.

For PWR decommissioning programs, the vessel will be segmented in the reactor cavity and the internals will be segmented in the service pool canals. Fuel canal water levels would have to be increased (installation of a canal gate) to provide adequate shielding during storage. The core shroud would be segmented and stacked in a tight array within the canal. The vessel would then be partially segmented and combined with core shroud segments to form a homogenized shipment. For BWR decommissioning programs, the vessel will be segmented in the reactor cavity, but most vessel internals segmentation will occur in the spent fuel pool where there is sufficient storage space for both the reactor vessel and core shroud segments.

The analysis of the homogenized cask shipment configurations yielded the results presented in Table $3.6-2 \mathrm{~b}$. The cost factors associated with the facilitation case included segmentation, packaging, shipment, and burial. Disposal costs (shipment and burial) were determined using published tariffs (Refs. 3-7\& 3-8) and assumed a $5 \emptyset \emptyset$ mile one-way trip to a regional burial facility. Segmentation and packaging costs were determined using the unit cost factor methodology presented in the AIE/NESP-DD9 study (Ref. 3-9).

The cask homogenization technique requires the cutting and handling of an additional $8 \emptyset$ vessel segments for the reference BWR, and a reduction of $3 \emptyset$ vessel segments for the reference PWR. The resulting total inches of cut for the referenced PWR/BWR are 6,153 and 36,520 , respectively. The costs, including material and labor associated with equipment setup, segmentation and handling, are $\$ 1,397,26 \varnothing$ for $a$ BWR and $\$ 235,41 \emptyset$ for a PWR.

\subsubsection{Conclusions}

Table 3.6-3 presents a summary of the results of the base and facilitation cases. As noted in this table, the analysis yielded positive results for both reference reactors. For the BWR, homogenization resulted in 35 fewer shipments (23\% reduction) with a corresponding reduction in wastes of $4,781 \mathrm{cu}$ ft (33\% reduction). 
TABLE $3 \cdot 6-2 a$

\section{SUMMARY TABLE: BASE CASE}

\begin{tabular}{|c|c|c|c|c|c|c|c|c|}
\hline Components & $\begin{array}{l}\text { No. of } \\
\text { Segments }\end{array}$ & $\begin{array}{l}\text { No: of Cask } \\
\text { Shipments }\end{array}$ & $\begin{array}{l}\text { Avg Weight } \\
\text { per Shipment } \\
\text { (lbs) }\end{array}$ & $\begin{array}{c}\text { Packing } \\
\text { Efficiency } \\
\text { ( } 8)\end{array}$ & $\begin{array}{l}\text { Avg } \\
\text { per }\end{array}$ & $\begin{array}{l}\text { Activity } \\
\text { Shipment } \\
\text { (Ci) }\end{array}$ & $\begin{array}{c}\text { Curie } \\
\text { Efficiency } \\
(8)\end{array}$ & $\begin{array}{l}\text { Burial } \\
\text { Volume } \\
\text { (cu } f t)\end{array}$ \\
\hline \multicolumn{9}{|l|}{ PWR } \\
\hline $\begin{array}{l}\text { RPV } \\
\text { Core shroud }\end{array}$ & $\begin{array}{r}72 \\
41 \\
113\end{array}$ & $\begin{array}{l}36 \\
41 \\
77\end{array}$ & $\begin{array}{r}817 \emptyset \\
660\end{array}$ & $\begin{array}{r}24.4 \\
2.0\end{array}$ & & $\begin{array}{r}291 \\
46460\end{array}$ & $\begin{array}{r}1.0 \\
99.0\end{array}$ & $\begin{array}{l}2448 \\
2780 \\
5236\end{array}$ \\
\hline \multicolumn{9}{|l|}{ BWR } \\
\hline $\begin{array}{l}\text { Reactor } \\
\text { Core Shroud }\end{array}$ & $\begin{array}{r}200 \\
87 \\
287\end{array}$ & $\begin{array}{r}67 \\
87 \\
154\end{array}$ & $\begin{array}{r}17420 \\
750\end{array}$ & $\begin{array}{r}27.1 \\
2.2\end{array}$ & & $\begin{array}{r}13 \\
46790\end{array}$ & $\begin{array}{r}4.3 \\
99.0\end{array}$ & $\begin{array}{r}8780 \\
5920 \\
14700\end{array}$ \\
\hline
\end{tabular}

TABLE $3 \cdot 6-2 b$

\section{SUMMARY TABLE: FACILITATION CASE}

\begin{tabular}{|c|c|c|c|c|c|c|c|c|c|}
\hline Components & $\begin{array}{l}\text { Cask } \\
\text { Type }\end{array}$ & $\begin{array}{l}\text { No. of } \\
\text { Cask } \\
\text { Segments }\end{array}$ & $\begin{array}{l}\text { No. of } \\
\text { Cask } \\
\text { Shipments }\end{array}$ & $\begin{array}{c}\text { Avg Weight } \\
\text { per Shipment } \\
\text { (1bs) }\end{array}$ & $\begin{array}{c}\text { Packing } \\
\text { Efficiency } \\
\text { ( })\end{array}$ & $\begin{array}{l}\text { Avg } \\
\text { per }\end{array}$ & $\begin{array}{l}\text { Activity } \\
\text { Shipment } \\
\text { (Ci) }\end{array}$ & $\begin{array}{c}\text { Curie } \\
\text { Efficiency } \\
\text { ( } 8)\end{array}$ & $\begin{array}{l}\text { Burial } \\
\text { Volume } \\
\text { (cu ft) }\end{array}$ \\
\hline $\begin{array}{l}\text { PWR } \\
\text { RPV } \\
\text { Core shroud }\end{array}$ & Vandenburg & $\begin{array}{l}42 \\
41 \\
83\end{array}$ & $\begin{array}{c}42 \\
\text { Inc. } \\
42\end{array}$ & 7,646 & 22.5 & 45 , &, 610 & 97.0 & 2,856 \\
\hline $\begin{array}{l}\text { BWR } \\
\text { Reactor } \\
\text { Core Shroud }\end{array}$ & CNS $8-12 \theta$ & $\begin{array}{r}100 \\
0\end{array}$ & 29 & 17,490 & 27.2 & & 4.3 & 1.5 & 3,799 \\
\hline $\begin{array}{l}\text { Reactor } \\
\text { Core Shroud }\end{array}$ & $\begin{array}{l}\text { Vandenburg } \\
\text { CNS } 8-12 \theta\end{array}$ & $\begin{array}{r}180 \\
87 \\
367\end{array}$ & $\begin{array}{l}90 \\
\text { Inc. } \\
\text { I19 }\end{array}$ & 8,026 & 24.2 & 45 , & 160 & 96.0 & $\begin{array}{l}6,120 \\
9,919\end{array}$ \\
\hline
\end{tabular}

Note: Packing efficiency equals the componenc volume/cask theoretical volume

Curie efficiency equals component curie estimate/allowable curie limit per shipment 
FIGURE 3.6-la

PWR VESSEL - SEGMENTATION SCHEMATIC
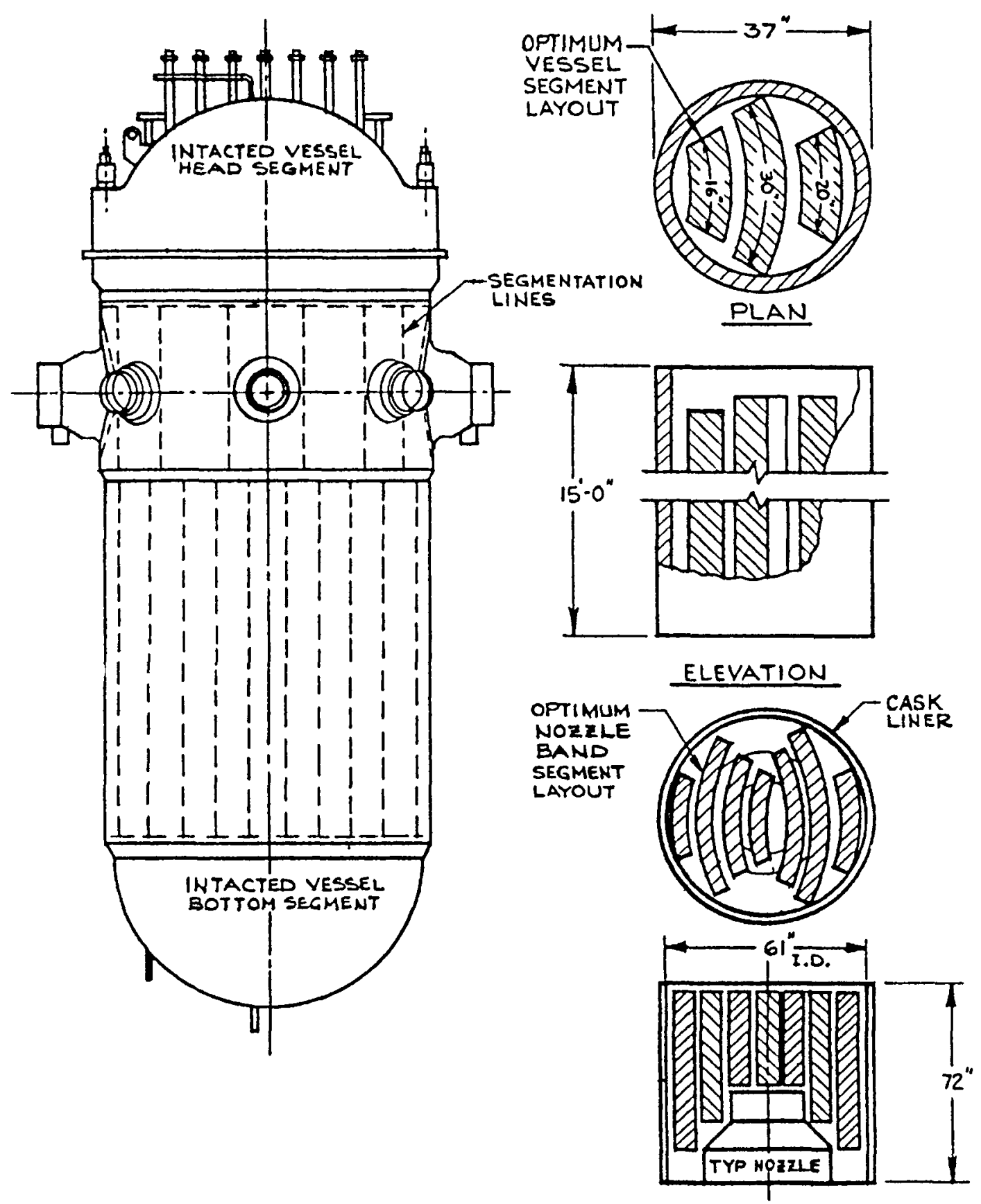

ELEVATIQN 
FIGURE $3.6-1 b$

PWR CORE SHROUD - SEGMENTATION SCHEMATIC
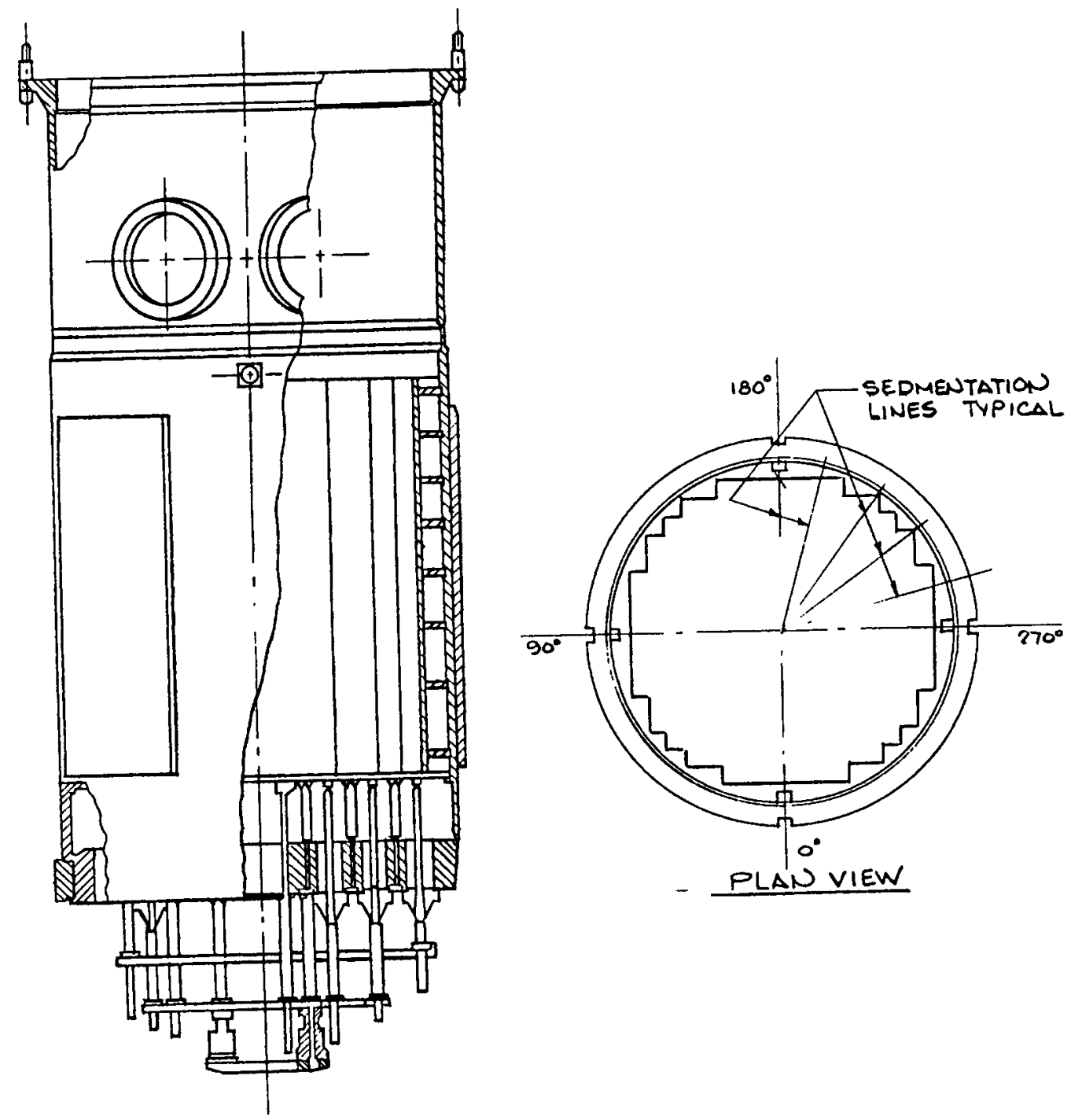


\section{FIGURE $3.6-2 a$}

BWR VESSEL - SEGMENTATION SCHEMATIC

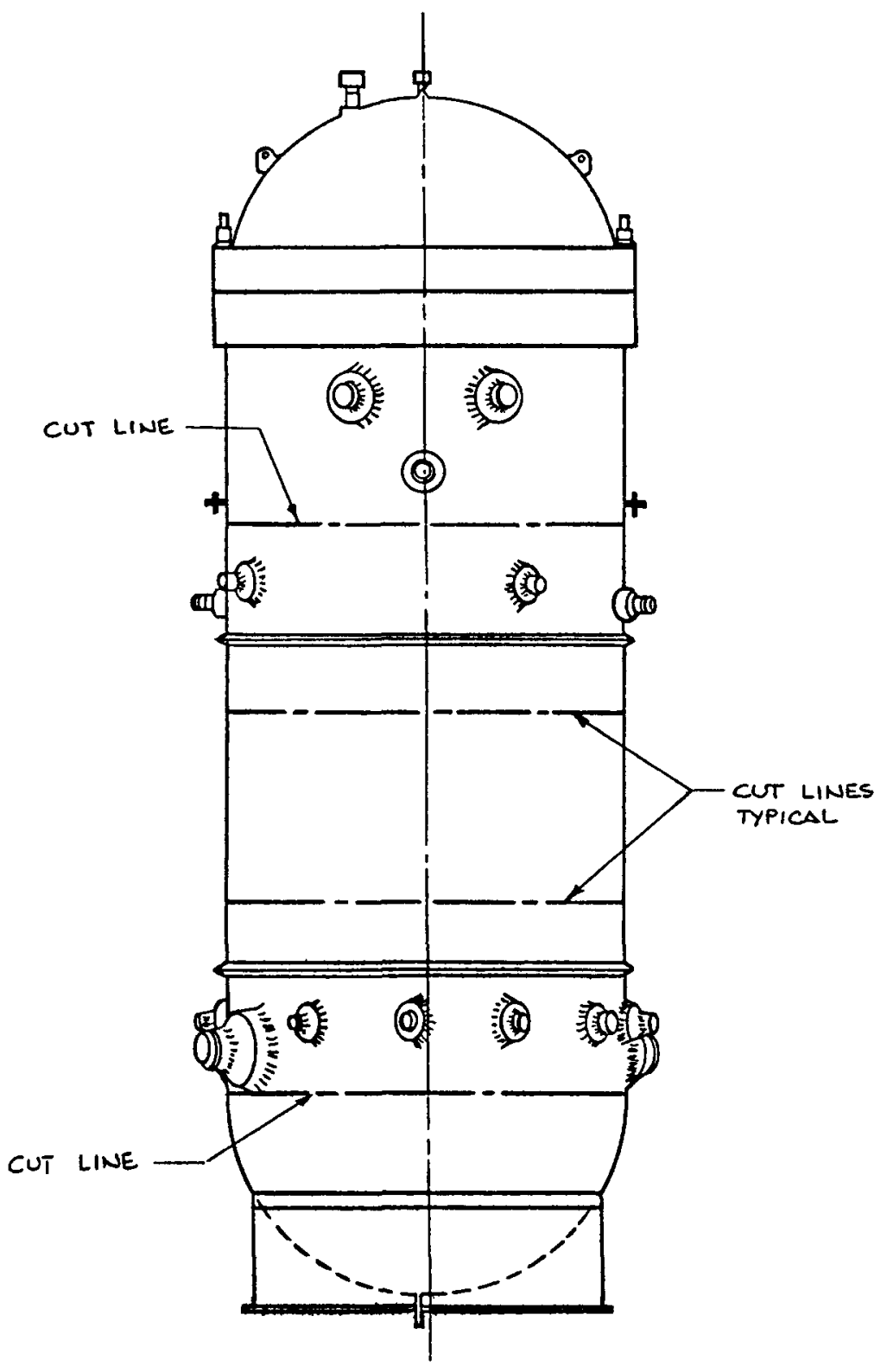




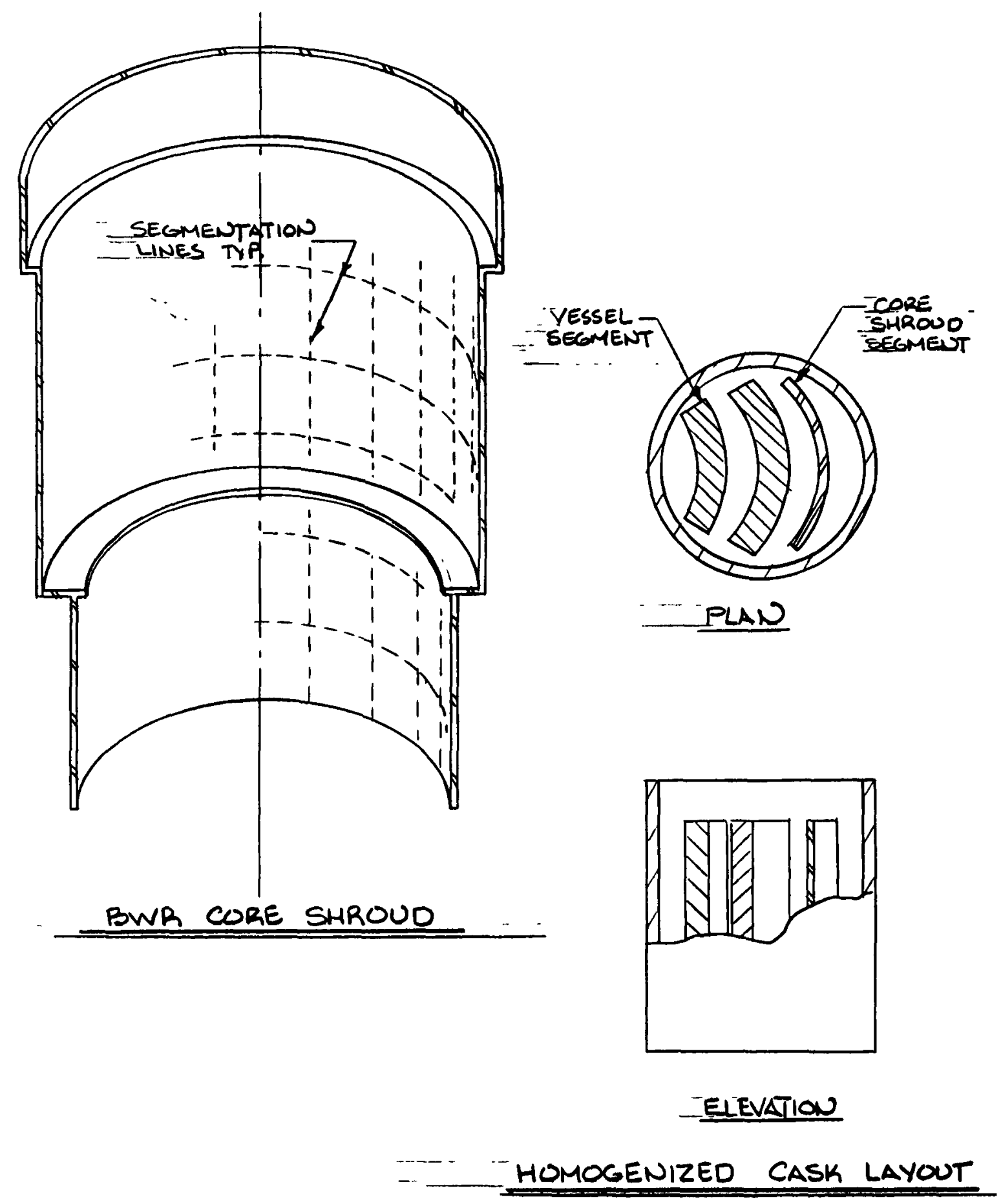


Note that only a small cost savings was realized because of the additional costs associated with generating more vessel segments.

TABLE $3 \cdot 6-3$

SUMMARY TABLE: BASE VS FACILITATION CASE

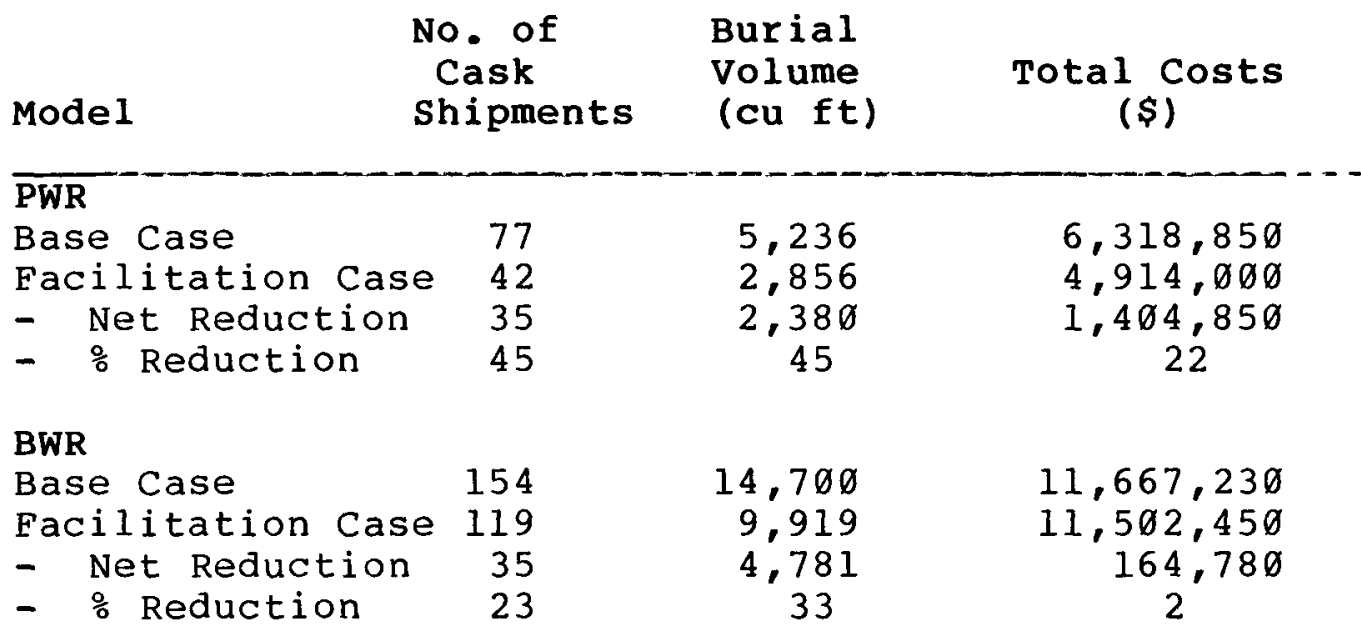

The referenced PWR case analysis provided similar results. Homogenization resulted in 35 fewer cask shipments (45\% reduction) and subsequently a waste reduction of $2380 \mathrm{cu} \mathrm{ft}$. The PWR case provided a better cost savings since homogenization requires less segmentation. This technique should be beneficial for all of today's commercial PWRs and the results presented herein should be readily achievable.

The success in applying this technique to today's commercial PWRS is dependent upon adequate storage area within the unit's refueling canal. Since the core shroud will be dismantled prior to vessel segmentation, sufficient space must be available to store the 41 core shroud pieces while segmenting the vessel. If care is taken in stacking the core shroud segments, sufficient area will be available to perform vessel segmentation operations. 


\subsection{CASK LINER GEOMETRY}

3.7.1 Description

This technique, identified as a potential method for reducing wastes, considered alternative configurations to existing standard cask liner geometries. The package void space could be reduced by using cask liners that better conform to the geometry of the waste. The increase in liner packing efficiency could then result in a reduction to subsequent wastes.

3.7.2 Objective

The objective of this cost benefit analysis was to determine the reduction in net exposures and wastes associated with conforming the burial package to the geometry of the waste form. The scope of the analysis was limited to the disassembly and disposal of the PWR vessel and internals. The disposal of these components constituted the major portion of the waste being transported by shipping cask to burial.

3.7.3 Approach and Methodology

During a decommissioning project, shielded shipping casks are required to safely dispose of the highly activated PWR vessel and internal segments. These activated segments are packaged, shipped and buried in commercially available shipping cask liners. This analysis evaluated the potential benefit of using custom designed instead of standard shipping cask liners. The approach was to first determine the wastes and exposures associated with removal and disposal of PWR vessel/ internals using commercially available shipping casks and liners. This technique was considered to be the base case. The facilitation case assumed that all vessel/internal segments would be transported in custom liners built to the configurations of the segmented waste.

The removal/dismantling activities for the PWR vessel and internals were considered to be similar in both cases. Variations between the two cases were only in the additional time required to load the specially shaped cask liners and the differences in the resulting burial volumes. 
3.7.4' Cost Benefit Analysis

3.7.4.1 Assumptions

1 The reference PWR and BWR reactor vessel and internals presented in the reference studies are used (Refs. $3-1 \& 3-2$ ).

2 Commercially available shipping casks are used for the base case technique evaluations, as presented in the reference PWR/BWR studies.

3 Vessel/internals configuration and curie content are assumed to be that presented in the PWR study, accounting for a two-year delay between reactor shutdown and actual vessel/internals segmentation operations.

4 Weight and curie limits are used as stated in the cask license, U.S. DOT and commercial burial facility requirements (Refs. $3-3 \& 3-7$ ).

5 Exposure estimates and packaging, shipping and burial costs are taken from the PWR study, with the costs escalated to 1984 dollars.

6 One-way shipping distances are assumed to be $50 \emptyset$ miles with transportation fees as stated in Tri-State Motor Transit Rate Schedule (Ref. 3-8).

7 Burial rates and guidelines are taken from ChemNuclear Systems, Inc. burial rate schedule for 1984 (Ref. 3-7).

8 Costs for segmentation labor and packaging are taken from the AIF/NESP- $\emptyset \emptyset 9$ Report and escalated at a rate of 6\% a year (Ref. 3-9).

\subsubsection{Base Case}

The base case considered the segmentation and removal of the $11 \varnothing \emptyset$ MWe reference PWR vessel/internals and the radioactivity level profiles presented therein. The segmentation and removal techniques include the underwater segmentation of internals. These components would then be loaded in conventional shipping casks for subsequent transportation and burial. Then the vessel would be segmented in air and loaded in shipping casks for shipment with the internals. 
The PWR study used two types of shipping casks for all activated radioactive waste transportation. The design specifications of these casks were similar to those commercially available. The vessel/internals segmentation scenarios were selected to meet the general design criteria of these shielded shipping casks. Table 3.7-1 presents the design specifications used by the PWR study as the basis for determining the base case vessel/internal size, weight and waste volume. The design criteria of these casks is based upon state road weight limits for maximum payload and a typical shipping cask NRC license for maximum curie content. The cask liner configuration is assumed to conform with the geometry and maximum dimensions of the shipping cask cavity.

TABLE $3 \cdot 7-1$

SPECIFICATIONS FOR SHIELDED CYLINDER SHIPPING CASKS (a)

Component

Liner

Activity

Dimension Limit (b)

(in)

(Ci)

Maximum

Payload (c)

(1b)

Vessel head, bottom, walls and nozzles

$4^{\prime} 6^{\prime \prime} \mathrm{OD}$

6' 3" long

Vessel

internals $\begin{array}{lll}5^{\prime} & 4 " & \text { OD } \\ 6^{\prime} & 3 " & \text { long }\end{array}$
$5 \emptyset, \emptyset \emptyset \emptyset$

$5 \emptyset, \emptyset \emptyset \emptyset$
$9, \emptyset \emptyset \emptyset$

$9, \emptyset \emptyset \emptyset$

(a) Information is taken from Table I.2-1 of the PWR study.

(b) Maximum curie levels assumed to be those specified in the NRC license of the largest commercial truck shipping cask (CNS-B-355) (Ref. 3-12)

(c) Maximum payload determined assuming maximum normal weight shipment of $73, \emptyset \emptyset \emptyset$ lbs, gross vehicle weight of $28, \emptyset \emptyset \emptyset \mathrm{lb}$ and cask empty weight of $36,0 \emptyset \emptyset$ lbs, as assumed in the PWR study. 
The base case assumed that all vessel and internal segments will be placed in disposable cylindrical liners. The package inefficiency of these base case liners is due to three limitations, the first being curie limits. presently available shipping casks are licensed to handle a maximum level of curies irrespective of available package volume. The second limitation is that of payload limits. Both DOT shipping regulations and NRC license requirements place weight limitations on cask shipment. Each state's DOT specifies maximum legal overweight shipment and the NRC places a payload restriction on the shipping cask itself. These limitations have been determined by accident analyses and are unrelated to DOT restrictions. The third limitation is geometry restriction. The vessel/internal segments are shaped irregularly, resulting in low packaging efficiencies (volume of segment/cask liner). Since burial volume is determined through cask liner volume, the low packaging efficiencies lead to large void spaces being considered as burial volume.

The base case assumed all three of these restrictions to determine the number of segments and cask 1 iners required to handle the disposal of the PWR vessel and internals. Table 3.7-2 presents the results of the base case analysis. In general, the packaging efficiency (waste/burial volume) of the component segments ranged from $\emptyset .6 \%$ to $17.9 \%$ of the burial volume. This resulted in a difference of $13,310 \mathrm{cu}$ ft between theoretical wastes (total weight/material density) and actual burial volume. Theoretical burial volumes are unrealistic; however, packaging efficiencies of between 50 to $7 \emptyset \%$ are obtainable.

A total of 178.4 manRem of exposure was estimated to be received by the decommissioning workers during the segmentation, packaging and shipping of the vessel/ internals for burial. Note that although the reactor internals had the largest curie content (approximately $4,800,33 \emptyset$ curies vs. 19,17ø curies for the vesse1), the exposure incurred during removal only slightly increased over vessel removal activities. This is because all internals segmentation and loading operations were completed underwater and the dose was only slightly greater than the vessel segmentation dose. Water acts as an excellent shield and this reduces overall exposures.

The costs of the base case include removal, packaging, shipping and burial of the vessel and internals. The assumptions supporting these costs are consistent with those presented in the PWR study. Cost figures have 
TABLE $3 \cdot 7-2$

CONVENTIONAL CASK LINER FOR PWR VESSEL/INTERNALS SEGMENTS (a)

\begin{tabular}{|c|c|c|c|c|c|c|c|c|c|c|c|}
\hline Component & Woight (b) & $\begin{array}{l}\text { Bstimated } \\
\text { Radioactivity } \\
\text { (Ci) }\end{array}$ & $\begin{array}{l}\text { No: of } \\
\text { Pleces }\end{array}$ & $\begin{array}{l}\text { No. of } \\
\text { Containers } \\
\text { (c) }\end{array}$ & $\begin{array}{l}\text { Payload per } \\
\text { Shippoent } \\
\text { (IDs) }\end{array}$ & $\begin{array}{l}\text { Average Radio- } \\
\text { activity Pet } \\
\text { shipment (Ibs) }\end{array}$ & $\begin{array}{l}\text { Volume par } \\
\text { Container } \\
\text { (eu } f(t)(d)\end{array}$ & $\begin{array}{l}\text { Packing } \\
\text { afficlency } \\
\text { (I) }\end{array}$ & $\begin{array}{l}\text { Burial } \\
\text { Volume } \\
\text { (cu } f t \text { ) }\end{array}$ & $\begin{array}{l}\text { Total Cost/ } \\
\text { Component (e) }\end{array}$ & $\begin{array}{c}\text { Total } \\
\text { Occupationa1 } \\
\text { Bxposure } \\
\text { (manRew) (f) }\end{array}$ \\
\hline $\begin{array}{l}\text { Presiure YesseI } \\
\text { - Cylindrical wall } \\
\text { - Vessel Head } \\
\text { - vessel Bottom }\end{array}$ & $\begin{array}{r}594,890 \\
195,006 \\
85,700\end{array}$ & $\begin{array}{r}19,170 \\
<10 \\
<10\end{array}$ & $\begin{array}{l}70 \\
20 \\
20\end{array}$ & $\begin{array}{l}69(31) \\
23(28) \\
20(28)\end{array}$ & $\begin{array}{l}8,750 \\
8,720 \\
4,567\end{array}$ & $\begin{array}{r}22,620 \\
<31,100 \\
<35,741\end{array}$ & $\begin{aligned} 17.5 \\
17 . \varepsilon \\
9.8\end{aligned}$ & $\begin{array}{r}17.9 \\
17.8 \\
9.3\end{array}$ & $\begin{array}{l}6900 \\
2300 \\
2000\end{array}$ & $\begin{array}{l}2,645,100 \\
1,265,200 \\
1,265,200\end{array}$ & 78.0 \\
\hline $\begin{array}{l}\text { Vessel Interasls } \\
\text { - UP Core Support Asgy } \\
\text { - UP Support Columns } \\
\text { - Upper Core Barrel } \\
\text { - Upper Core Grid plate } \\
\text { - Guide Tubes } \\
\text { - Lower, Core Barel } \\
\text { - Thermal Shields } \\
\text { - Core Shroud (b) } \\
\text { - Lower Grid Plate (b) } \\
\text { - LW Support Columns } \\
\text { - Lower Core Forging }\end{array}$ & $\begin{array}{r}26,500 \\
24,500 \\
6,900 \\
10,200 \\
33,390 \\
94,000 \\
23,006 \\
27,190 \\
8,760 \\
7,400 \\
89,400\end{array}$ & $\begin{array}{r}<19 \\
<100 \\
<1,000 \\
24,316 \\
<100 \\
651,006 \\
146,108 \\
3,431,090 \\
553,480 \\
19,006 \\
2,500\end{array}$ & $\begin{array}{r}12 \\
96 \\
18 \\
9 \\
122 \\
64 \\
12 \\
96 \\
12 \\
96 \\
25\end{array}$ & $\begin{array}{r}4(4) \\
4(4) \\
2(2) \\
5(5) \\
6(6) \\
32 \\
6 \\
4 \\
5 \\
1 \\
11(7)\end{array}$ & $\begin{array}{r}6,907 \\
6,407 \\
3,282 \\
2,322 \\
5,832 \\
2,938 \\
3,838 \\
288 \\
725 \\
7406 \\
7,778\end{array}$ & $\begin{array}{r}<35,743 \\
<35,765 \\
<36,240 \\
49,602 \\
<35,757 \\
20,340 \\
24,350 \\
<35,740 \\
<46,120 \\
19,000 \\
29,574\end{array}$ & $\begin{array}{r}14.1 \\
13.1 \\
6.7 \\
4.7 \\
11.9 \\
6.9 \\
7.8 \\
9.6 \\
1.5 \\
15.1 \\
15.9\end{array}$ & $\begin{array}{r}14.1 \\
13.1 \\
6.7 \\
4.7 \\
: 1.9 \\
6.6 \\
7.8 \\
8.6 \\
1.5 \\
15.1 \\
15.9\end{array}$ & $\begin{array}{r}460 \\
400 \\
280 \\
560 \\
600 \\
3200 \\
600 \\
400 \\
560 \\
106 \\
1100\end{array}$ & $\begin{array}{r}255,900 \\
257,990 \\
139,200 \\
348,909 \\
382,309 \\
2,227,509 \\
417,609 \\
278,400 \\
348,000 \\
69,608 \\
765,700\end{array}$ & 109.4 \\
\hline TOTAL & $1,216,600$ & $4,819,520$ & & 158 & & & & & 19,200 & $10,665,600$ & 178.4 \\
\hline
\end{tabular}

(a) Information taken from Table G.4-3 of NUREG/CR-6130; note modification made to meet payload limits

(b) A majority of core shroud and lower grid plate segments were distributed to containers of other components. This included 92 core shroud segments and 7 lower grid plate segments. Note that of lower grid plate segments

(c) Contalner values enclosed in parenthesis Include the number of core shroud segments distributed to that particular

(d) Container burial volume equal to 100 cubic feet

(e) Costs are developed using assumptions presented in NUREG/CR-9130 but revised to 1984 dollars

(f) Occupational exposure estimates extracted from Tabla G.3-1 of NUREG/CR-a13g 
been revised by applying 1984 costs elements (labor, materials, transportation rates and burial fees) to those assumptions.

\subsubsection{Facilitation Case}

The facilitation case assumes that the pressure vessel head, bottom and nozzle band are segmented and loaded in conventional liners. However, special annular section liners will be used for shipping vessel cylindrical walls. Figure 3.7-1 presents a schematic of a typical annular sector liner loaded with a vessel wall segment.

A11 vessel internals components were segmented and loaded into custom designed disposable liners. optimization of the liner geometry to waste form shape lead to four different liner configurations. Three of these were annular sector 1 iners and one was of the rectangular design. Table $3.7-3$ presents the liner types selected for both the vessel and internal component segments.

Segmentation patterns and packing arrays were determined for each of the internal components. Criteria used in determining segment configurations were (1) dimensional limitations of the liners, (2) shipping cask payload (< $9, \varnothing \emptyset \emptyset$ Ibs) limits set forth by DOT regulations or NRC licenses, and (3) activity limits set forth by NRC cask license $(<5 \emptyset, \emptyset \emptyset \emptyset \mathrm{Ci})$. Using these criteria and the aforementioned configurations, several internals were segmented and loaded into similar liners. The lower grid plate, upper support columns and guide tubes were combined into 12 rectangular Iiners. The upper core support assembly, upper core grid plate, core shroud lower support columns and lower core forging were segmented and combined into 72 rectangular liners. The upper core barrel, thermal shield and lower core barrels were segmented with each components' segments being loaded into its own annular liners $(2,3$, and $2 \emptyset$ liners, respectively). Table 3.7-4 presents the results of the facilitation analysis.

The exposures associated with the facilitation case was calculated using component dose rates similar to those of the base case. However, it was assumed that a longer period of time would be required to load the custom liners. These resulted in increasing exposure incurred during some of the component handling activities. The major increase occurred when handiing the reactor wall segments. These segments are moved in air, thus subjecting the workers to additional exposure. 
FIGURE 3.7-1

SCHEMATIC OE LOADED ANNULAR SECTOR LINER

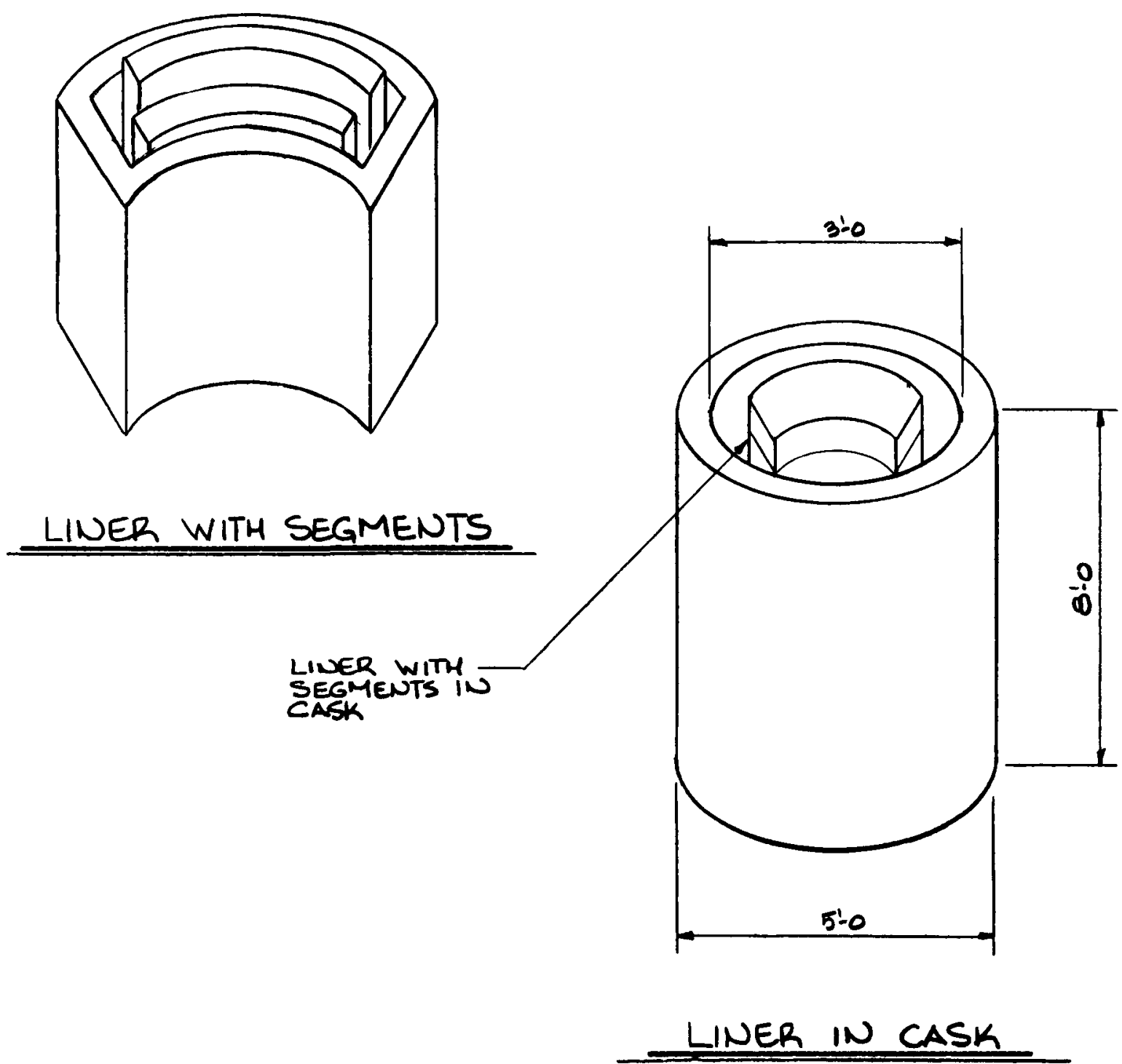


TABLE $3.7-3$

LINER GEOMETRY CONFIGURATIONS: FACILITATION CASE

Components

Vesse1:

- head

- bottom

- nozzles

Walls

Internals:

- UC Support Assy Rec

- UC Grid Plate

- Guide Tubes

- Up Support Columns Rec

- Lw Support Columns Rec

- Core Shroud

- Lw Grid Plate

Lower Core Forging:

- Up Core Barrel

- Lw Core Barrel

- Thermal Shield
Ann

Liner

Type

Cyl

Cyl

Cyl

Ann

Rec

Rec

Rec

Rec

Ann

Ann

\section{Dimensions}

Burial

Vol.(ft3) $\begin{array}{lll}4.53^{\prime} \mathrm{OD} \times 6.25^{\prime} \mathrm{H} & 1 \emptyset \emptyset \\ 4.53^{\prime} \mathrm{OD} \times 6.25^{\prime} \mathrm{H} & 1 \emptyset \emptyset \\ 4.53^{\prime} \mathrm{OD} \times 6.25^{\prime} \mathrm{H} & 1 \emptyset \emptyset\end{array}$

$0.96^{\prime} \mathrm{W} \times 3.2^{\prime}$ arc 20 $\times 6.25^{\prime} \mathrm{H}$
54

54

$2.41^{\prime} \mathrm{W} \times 3.58^{\prime} \mathrm{D}$

$\mathrm{x} 6.25^{\prime} \mathrm{H}$

$2.41^{\prime} \mathrm{W} \times 3.58^{\prime} \mathrm{D}$

54

$\mathrm{x} 6.25^{\prime} \mathrm{H}$

$2.41^{\prime} \mathrm{W} \times 3.58^{\prime} \mathrm{D}$

$\mathrm{x} 6.25^{\prime} \mathrm{H}$

$2.41^{\prime} \mathrm{W} \times 3.58^{\prime} \mathrm{D}$

$\times 6.25^{\prime} \mathrm{H}$

$2.41^{\prime} \mathrm{W} \times 3.58^{\prime} \mathrm{D} \quad 54$

$\times 6.25^{\prime} \mathrm{H}$

$2.41^{\prime} \mathrm{W} \times 3.58^{\prime} \mathrm{D}$

$\mathrm{x} 6.25^{\prime} \mathrm{H}$

$0.96^{\prime} \mathrm{W} \times 3.75^{\prime} \operatorname{arc}$

$\times 6.25^{\prime} \mathrm{L}$

$0.83^{\prime} \mathrm{W} \times 3.17^{\prime} \mathrm{arc} 23$

$\times 6.25^{\prime} \mathrm{L}$

$0.96^{\prime} \mathrm{W} \times 4.33^{\prime} \mathrm{arc} 20$

$\times 6.25^{\prime} \mathrm{L}$ 
TABLE 3.7-4

CUSTOM DESIGNED CASK LINER FOR PWR VESSEL/INTERNALS SEGMENTS

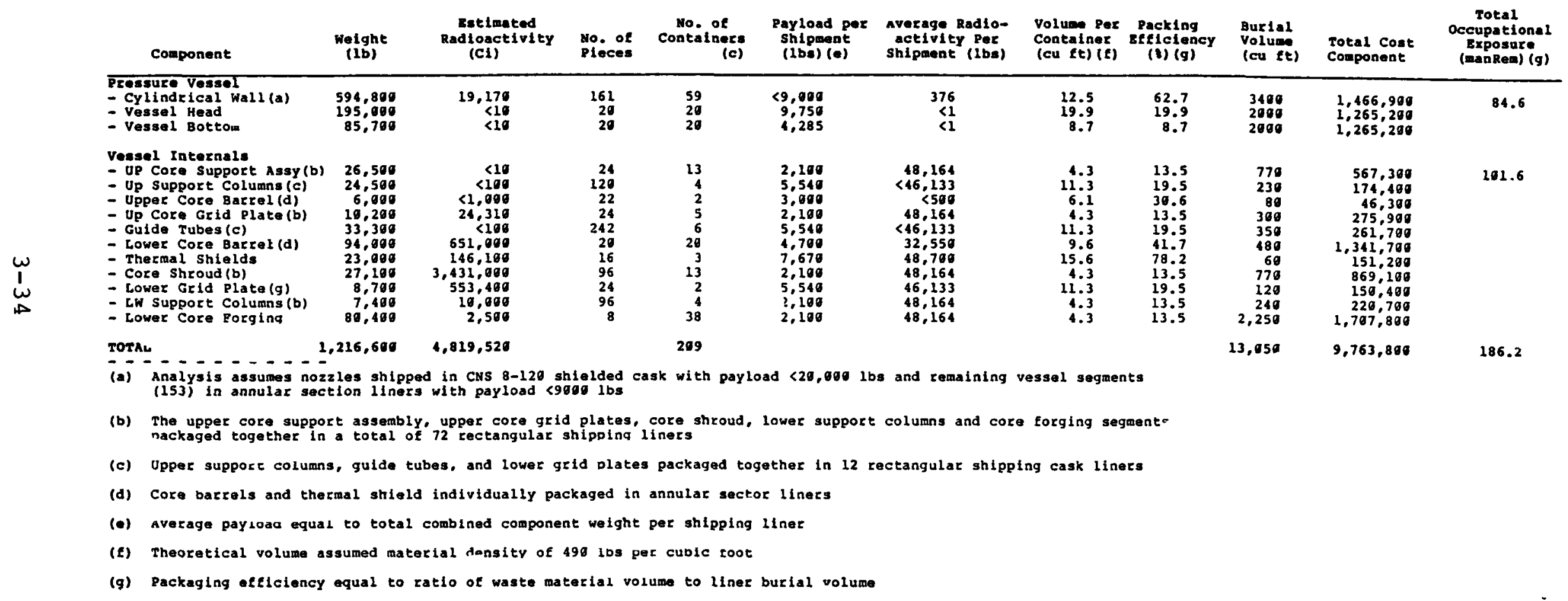


The facilitation case total cost includes the removal, packaging, shipping and burial cost elements. These costs included the additional fees for custom liner purchase and cost reduction associated with reduced wastes.

3.7.5 Conclusions

A comparison between the two analyses shows that a reduction in wastes and costs can be achieved with more efficient cask liner geometries. However, a small increase in exposure ocurred because of the additional vessel segmentation and time necessary to cut and load segments into the more restrictive liners. Table 3.7-5 presents a summary of the comparison between the two cases.

TABLE 3.7-5

CASK LINER GEOMETRY: BASE CASE vS FACILITATION CASE

\begin{tabular}{lrrr} 
Comparison & $\begin{array}{c}\text { Occupational } \\
\text { Exposure } \\
\text { (manRem) }\end{array}$ & $\begin{array}{c}\text { Burial waste } \\
\text { Volume } \\
\text { (cu } \mathrm{ft} \text { ) }\end{array}$ & $\begin{array}{c}\text { Cost } \\
(\$)\end{array}$ \\
\hline Base Case & 178.4 & $19,20 \emptyset$ & $10,665,6 \emptyset \emptyset$ \\
Facilitation Case & 186.2 & $13, \emptyset 5 \emptyset$ & $9,763,8 \emptyset \emptyset$ \\
Net Reduction & $(7.8)$ & $6,15 \emptyset$ & $9 \emptyset 1,8 \emptyset \emptyset$ \\
Percentage (\%) & $(4.4)$ & $32 . \emptyset$ & 8.5
\end{tabular}


3.8 END OF LIFE DECONTAMINATION

3.8.1 Description

This technique was identified to reduce dose rates (and therefore exposures) incurred during the removal and disposition of the primary coolant system piping and associated equipment.

3.8.2 Objective

The purpose of this cost benefit analysis was to determine whether end of life decontamination could reduce exposure during component removal, its resulting wastes and associated cost.

3.8.3 Approach and Methodology

The analysis evaluated the activities to remove, package, ship and bury PWR primary system components two years after shutdown (with and without decontamination). The analysis assumed the decontaminated components would still require controlled burial because chemical decontamination has not been effective in achieving unrestricted use levels in these components. Using this approach, the increased costs were only those associated with decontamination. For BWR decontamination, the analysis followed the same approach to identify the costs, exposures and wastes.

\subsubsection{Cost Benefit Analysis}

\subsubsection{Assumptions}

1 PWR and BWR primary system components description and radioactive inventory were taken from the reference studies (Refs. 3-1 \& 3-2).

2 PWR system components include the Reactor coolant system (RCS) piping, pumps, relief tanks, safety injection and steam generators; Chemical Volume Control system (CVCS); and Residual Heat Removal (RHR) system.

3 BWR system components include the Reactor Recirculation (RRC), Reactor Water Cleanup (RWCU), Residual Heat Removal (RHR), Low pressure core spray (LPCS), High Pressure Core spray (HPCS), and the Fuel pool cooling (FPC) systems.

4 PWR decontamination solvent is assumed to be a 5 wto solution of citrox/EDTA (Refs. 3-1\&3-2). 
BWR decontamination solvents are assumed to be 5 wt: citrox/EDTA for recirculatory decontamination, and 10 wt\% phosphoric acid for single-pass decontamination (Refs. 3-1 \& 3-2).

6 The decontamination effectiveness for both the PWR and BWR is a DF of 10 overall (Refs. 3-1 \& 3-2).

7 No water rinses are needed following chemical decontamination.

8 Decontamination does not permit release of the components for unrestricted use because of tightly adherent residual contamination; controlled removal and burial will be required.

9 Removal of components after decontamination requires the same labor as without decontamination because the components are still contaminated. The same precautions and preparations, contamination controls and packaging would be required.

\subsubsection{Base Case}

The base case analysis for the PWR considered removal, packaging, shipping and burial of the RCS, CVCS and RHR systems (exclusive of the reactor vessel). The exposure was based on the dose from components being a factor of 10 higher than reported in the PWR study for the predecontamination case. The results of this PWR analysis for the base case are shown in Table 3.8-1a. The base case for the BWR is similar to the PWR base case. The estimated BWR costs, wastes and exposures for systems removal are shown in Table 3.8-1b.

\subsubsection{Facilitation Case}

The facilitation case analysis for the PWR considered decontamination (Citrox/EDTA process) and removal, packaging, shipping and burial of the same systems as the base case. Decontamination dose reductions were accounted for in removal of components after chemical decontamination. Waste increases were estimated to account for the additional volumes needed to solidify and package decontamination solvents for disposal. Similarly, the increased costs to purchase chemicals, decontaminate, package, ship and bury wastes from the decontamination process were estimated. Based on the assumption (item 8 above) that components will remain contaminated after decontamination, the costs and wastes of these components will be identical to the base case. 
TABLE $3.8-1 a$

SYSTEM REMOVAL: PWR

\begin{tabular}{|c|c|c|c|c|c|c|c|}
\hline \multirow[b]{2}{*}{ system } & \multicolumn{3}{|r|}{ Costs (\$) } & piriat & \multirow{2}{*}{ Total } & \multirow{2}{*}{$\begin{array}{l}\text { Volume } \\
(c u f t)\end{array}$} & \multirow{2}{*}{$\begin{array}{l}\text { Exposure } \\
\text { (manRem) }\end{array}$} \\
\hline & Removal & Package & & & & & \\
\hline $\begin{array}{l}\text { Reactor Coolant } \\
\text { Steam Generators } \\
\text { Chem/Volume Control } \\
\text { Residual Heat Removal } \\
\text { Totals }\end{array}$ & $\begin{array}{r}710,550 \\
345,546 \\
116,432 \\
78,197\end{array}$ & $\begin{array}{r}255,840 \\
4,680 \\
6,760 \\
2,080\end{array}$ & $\begin{array}{r}104,744 \\
91,666 \\
3,488 \\
2,846\end{array}$ & $\begin{array}{r}413,386 \\
591,733 \\
31,620 \\
9,730\end{array}$ & $\begin{array}{r}1,484,520 \\
1,033,025 \\
158,300 \\
92,853 \\
2,768,698\end{array}$ & $\begin{array}{r}16,700 \\
21,362 \\
1,664 \\
\quad 512 \\
40,139\end{array}$ & $\begin{array}{r}1,320 \\
1,440 \\
850 \\
290 \\
3,900\end{array}$ \\
\hline
\end{tabular}

TABLE $3.8-1 \mathrm{~b}$

SYSTEM REMOVAL : BWR

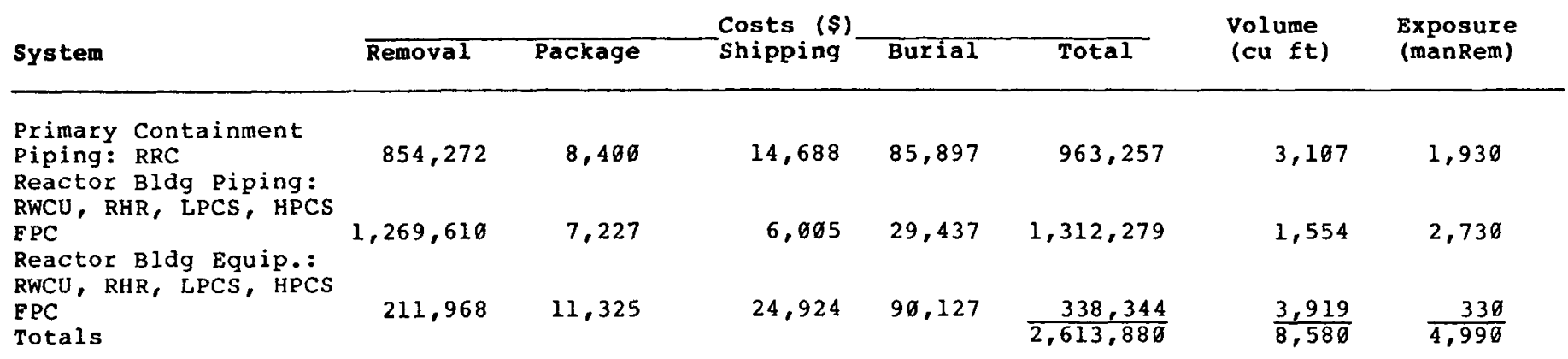


The additional costs for chemical decontamination are shown in Table 3.8-2a. The overall decontamination and removal results are shown in Table 3.8-3a. If significant concentrations of chelating agents (EDTA) are used, an additional treatment step may be required, such as heating the solvent to a high temperature to break down EDTA or combining it with agents to increase the molecular size of the chelating agent (and therefore reduce leachability) to make it suitable for burial. such treatment is beyond the scope of this study.

TABLE 3.8-2a

SYSTEM DECONTAMINATION: PWR

Item

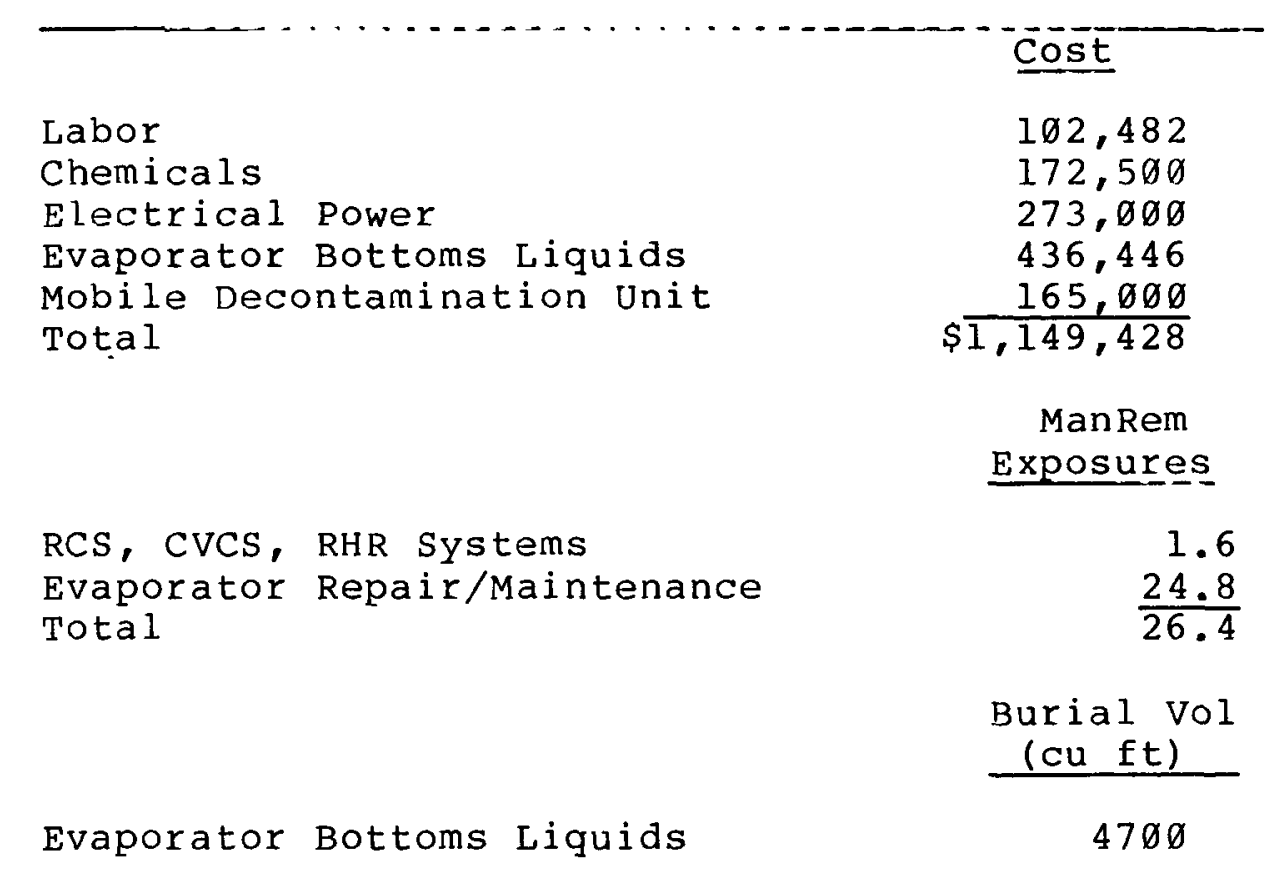

TABLE $3.8-3 a$

SYSTEM DECONTAMINATION AND REMOVAL: PWR

$\begin{array}{cccc}\text { Activity } & \text { Cost } & \text { Waste Vol } & \text { Exposure } \\ \text { (manRem) }\end{array}$

\begin{tabular}{llcr}
\hline System Decon & $1,149,428$ & $4,7 \emptyset \emptyset$ & \\
System Removal & $\frac{2,768,698}{3,918,126}$ & $\frac{4 \emptyset, 139}{44,839}$ & \\
Totals & & & $\frac{39 \emptyset . \emptyset}{416.4}$
\end{tabular}


The analysis for the BWR considered decontamination of the RRC, RWCU, RHR, LPCS, HPCS and FPC systems. The cost for this technique is the cost for the chemical decontamination process and disposal of the wastes, as in the case of the PWR. The waste increase is from the disposal of solidified solvents, and the exposure reduction is the net of the system removal reduction and the increase due to decontamination. These decontamination costs, exposures and wastes are shown in Table 3.8-2b. The overall decontamination and removal results are shown in Table $3.8-3 b$.

TABLE $3.8-2 b$

SYSTEM DECONTAMINATION: BWR

Item

Cost

Labor

Chemicals

Electrical power

Evaporator Bottoms Liquids

Mobile Decontamination Unit Total RRC, RWCU, RHR, LPCS, HPCS,
\& EPC Systems

Evaporator Repair/Maintenance Total

Evaporator Bottoms Liquids
361,694

597,960

109,577

$1,082,095$

$\$ \frac{168,75 \emptyset}{\$ 2,320,076}$

Man Rem

Exposures

17

$\frac{21}{38}$

Burial Vol

(cu ft)

11,299

TABLE $3.8-3 b$

SYSTEM DECONTAMINATION AND REMOVAL: BWR

Activity

Cost

(\$)
Waste Vol

(cu $f t$ )
Exposure (manRem)
System Decon

System Removal Totals
$2,320,076$

$\frac{2,613,880}{4,933,956}$

11,299

$1 \frac{8,580}{19,879}$ 38

499 


\subsubsection{Conclusions}

The cost benefit analysis indicates there is a large overall reduction in exposures if contaminated primary coolant and associated systems are decontaminated prior to removal. The estimated increase of wastes from decontamination is minimal compared to the total volume of materials to be shipped for burial. Accordingly, for large PWR and BWR facilities with contamination accumulated over 40 years of operation, end of life decontamination is cost effective for this analysis. The results of the PWR and BWR analyses are shown in Table 3.8-4. The parentheses indicate a negative reduction, or in other words, an increase.

TABLE $3.8-4$

ANALYSIS: END OF LIEE DECONTAMINATION

\begin{tabular}{|c|c|c|c|}
\hline $\begin{array}{c}\text { Evaluation } \\
\text { Category }\end{array}$ & $\begin{array}{l}\text { Base } \\
\text { Case }\end{array}$ & $\begin{array}{c}\text { Facilitation } \\
\text { Case }\end{array}$ & $\begin{array}{c}\text { Net } \\
\text { Reduction }\end{array}$ \\
\hline
\end{tabular}

PWR

Radiation

Exposure,

$3,9 \emptyset \emptyset$

416.4

$3,483.6$

89.3

man Rem

Waste Volume, $4 \emptyset, 139$

44,839

$(4,700)$

$(11.7)$

$\mathrm{cu} \mathrm{ft}$

cost, $\$$

$2,768,698$

$3,918,126$

$(1,149,428)$

$(41.5)$

BWR

Radiation

Exposure,

4,990

537

4,453

89.2

man Rem

Waste Volume,

$8,58 \emptyset$

19,879

(11, 299)

(131.7)

$\mathrm{cu} f t$

cost, $\$$

$2,613,88 \emptyset$

$4,933,956$

$(2,32 \emptyset, 076)$

$(88.8)$ 
3.9.1 Description

The technique of high-temperature incineration of LSA waste is considered as a means of reducing wastes sent to controlled burial facilities.

3.9.2 Objective

The objective of this cost benefit analysis is to determine the net reduction in waste quantities generated during reactor decommissioning from incinerating LSA waste. The analysis included the exposures and cost for incineration.

3.9.3 Approach and Methodology

The analysis included estimation of typical volumes of dry active waste (DAW)/LSA waste generated during PWR and BWR plant decommissioning. These estimates were used in the analysis for the base case for direct burial, and for the facilitation case for incineration. The exposure, wastes and cost to dispose of these wastes were estimated for each case. The facilitation case included the extra handling required to load the incinerator, collect and solidify the ash and dispose of the liquid scrubber system liquids. Disposal of scrubber solution liquids consisted of neutralization, filtration, evaporation, demineralization and solidification of evaporator bottoms, and disposal of spent demineralization resins and filter media. The cost analysis included the capital equipment for the incinerator, solidification system for spent liquids, reduced number of containers required and reduced burial costs.

Although waste incineration technology is well established, few incinerator systems have been licensed. In order to use this facilitation technique, any PWR/BWR would have to maintain an appropriate license to incinerate. However, utilities are actively considering incineration for disposal of operating plant wastes and are preparing licensing amendments to include incineration within their operating licenses. As such, this cost benefit analysis assumed that no additional licensing effort would be required to use this technique during decommissioning, since the system would remain operational during decommissioning. 


\subsubsection{Cost Benefit Analysis}

\subsubsection{Assumptions}

1 The facility maintains an active license to incinerate DAW during the dismantling project.

2 The capital cost of the incinerator assigned to the decommissioning project is a function of its yearly potential use (for the operating reactor and the reactor being decommissioned).

3 LSA waste volume quantity is taken from the reference studies (Refs. 3-1 \& 3-2).

4 One-way shipping distance is assumed to be $5 \emptyset \emptyset$ miles.

5 Shipping and burial rates used in the analysis are obtained from 1984 published rate schedules used by the industry (Refs. $3-7 \& 3-8$ ).

6 Economic life of the mobile incinerator system is assumed to be 6 years.

7 Residual incinerated ash is evaluated for solidification and containment in three different solidification configurations: cement, polymer and high integrity containers.

8 All combustible LSA waste is compacted prior to incineration.

9 Dose rate from compacted drums is assumed to be the same as reported in the reference PWR and BWR studies, Tables G.3-1 and I.4-1, respectively. For a PWR, the dose rate is $3 \emptyset \mathrm{mR} / \mathrm{hr}$ and for a BWR, 22 $\mathrm{mR} / \mathrm{hr}$.

10 An incineration/solidification crew (2-man) will be exposed to the above dose rates per drum before incineration, and at double these rates after incineration due to concentration of radioactivity in the ash and scrubber sludge. Shielding used during burning and solidification equals $1 / 10$ dose.

11 Transport driver receives $1 / 2$ the maximum allowable dose rate in occupied locations of the vehicle, equal to $1 \mathrm{mR} / \mathrm{hr}$ for all shipments. This dose rate will be achieved by shielding as needed for each shipment. A 5-day shipping time ( $4 \varnothing$ hours) is assumed for all cases. Thus, $4 \emptyset$ manhours $x \mathrm{lmR} / \mathrm{hr}$ equals $4 \emptyset$ manRem per trip. 


\subsubsection{Base Case}

The base case was developed using the waste estimates delineated for the reference PWR and BWR plants presented in the reference studies. The DAW was assumed to be compacted to a $5: 1$ ratio (Ref. 3-13), readily achievable with current equipment. Table 3.9-1a presents a summary of the parameters used to represent the base case models in the cost benefit analysis.

The costs associated with the disposal of DAW included packaging costs (using carbon steel 55-gallon drums) and the transportation/burial costs from published rate schedules (Refs. 3-7 \& 3-8). For DAW requiring cask shipment, additional costs included cask rental, cask handling and weight surcharges.

\subsubsection{Facilitation Case}

The facilitation case was developed on the basis of technical incineration data presented by EPRI, Gilbert Associates, Ontario Hydro and the Mound Laboratory (Refs. 3-13, 3-14, 3-15\&3-16). These case studies were restricted to the use of a mobile incinerator primarily because stationary incinerators are approximately 25 times the capital cost of a mobile unit. In addition, installation of a permanent facility exclusively for decommissioning would not be practical or cost effective because of the relatively short duration.

TABLE $3 \cdot 9-1 a$

BASE CASE DISPOSAL OF COMPACTED WASTE

$\begin{array}{lccl}\text { Type of } & \text { LSA Volume } & \text { Compacted } \\ \text { Transport } & \text { (cu } f t) \quad \text { (drums) } & \text { (cu ft) (drums) } & \text { Cost (\$) }\end{array}$

\section{PWR}

$\begin{array}{lrrrrr}\text { Cask } & 15,75 \emptyset & 2,10 \emptyset & 3,15 \emptyset & 42 \emptyset & 296,657 \\ \text { Unshielded } & \frac{34,875}{50,625} & \frac{4,65 \emptyset}{6,75 \emptyset} & \frac{6,975}{1,125} & \frac{93 \emptyset}{1,35 \emptyset} & \frac{357,955}{654,612} \\ \text { Total } & \frac{10,125}{50}\end{array}$

BWR

Cask

Unshielded Total

$\begin{array}{rrrrr}37,111 & 5, \emptyset \emptyset \emptyset & 7,422 & 1, \emptyset \emptyset \emptyset & 663, \emptyset 97 \\ \frac{82,536}{119,647} & \frac{11,12 \emptyset}{16,12 \emptyset} & \frac{16,507}{23,929} & \frac{2,224}{3,224} & \frac{756,933}{1,42 \emptyset, \emptyset 3 \emptyset}\end{array}$


A mobile incinerator was assumed to be placed on-site to handle the wastes generated. The Mound Laboratory drum-type incinerator was used as the model because of its relatively long successful operating history and small size suitable for incorporating within mobile trailers. A conceptual layout of the mobile incinerator is shown in Figure 3.9-1.

Capital costs (including licensing) for the mobile incinerator were estimated and amortized over a 6-year period for the case of decommissioning (the length of a typical dismantling program). The analysis also assumed that the mobile incinerator would not be totally dedicated to the decommissioning project and thus would be available to other facilities. As such, the capital cost was distributed as a function of the amount of waste generated during the dismantling project.

Mound Laboratory reference material indicated the incinerator has a capacity of $7 \mathrm{cu}$ ft per hour. With allowances made for downtime and general maintenance, the mobile unit selected was able to hande approximately $13,44 \varnothing$ cu ft annually. The Mound Laboratory incinerator was used as a performance model because of the large amount of available data. Allowing for disposition of the off-gas system byproducts (by solidification) and the ash being placed into high integrity containers, an overall volume reduction factor of 22 was achieved. Incinerated ash combined with a cement solidification binder produced an overall volume reduction factor of 7 ; if a polymerization process (Ref. 3-17) was employed, the reduction factor increased to 14 .

In addition to the volumetric analysis, a cost comparison was made for the two disposition alternatives (compaction and incineration) to determine if the incineration gain was strictly volumetric or if costs were competitive with conventional disposition. The initial capital cost for the mobile incineration case was approximately $\$ 1,86 \emptyset, \varnothing \emptyset \emptyset$ with an annual operating cost of approximately $\$ 285, \emptyset \emptyset \emptyset$. The ash volume estimate in each of the three solidification techniques was obtained from the Mound Laboratory data. The cost benefit analysis compared the base case disposal costs to the incineration technique costs (percent of capital, operating costs solidification, package, ship and buriall.

For the exposure comparison, only those activities that would generate different exposures for the base and facilitation cases were considered. It was assumed that similar exposure would be incurred during the packaging 
FIGURE $3 \cdot 9-1$

MOBILE INCINERATOR CONCEPTUAL LAYOUT

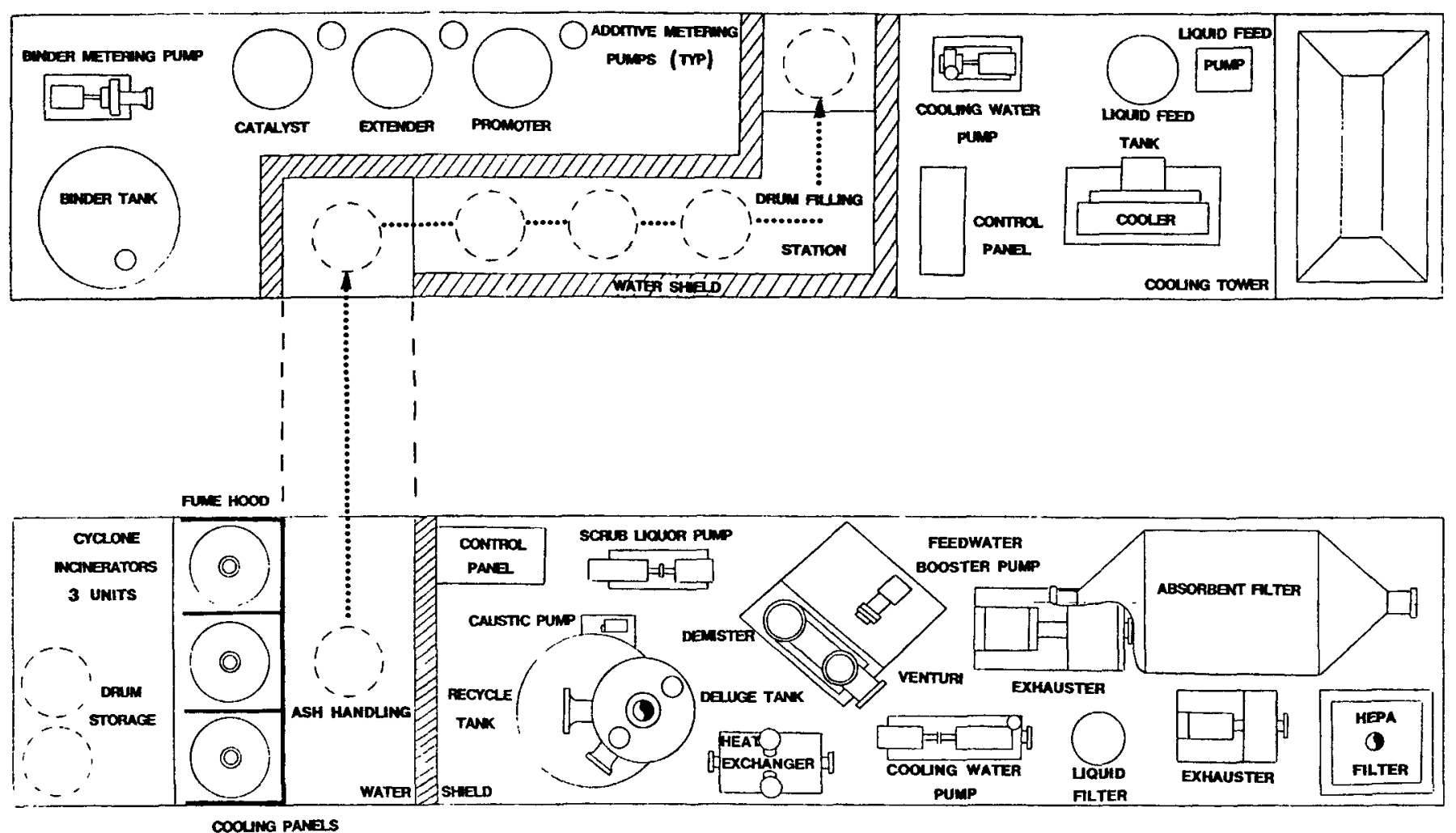


and handling of the compacted DAW. Exposure differences occurred between the two models during the transportation activities where the incinerated DAW had higher activity levels because of concentration.

Additional exposure would also be incurred during the process of incinerating and processing the ash. Dose rates from compacted drums (used to determine the additional exposures) were also obtained from the PWR and BWR studies. The PWR dose rate is $3 \emptyset \mathrm{mR} / \mathrm{hr}$ and the BWR rate is $22 \mathrm{mR} / \mathrm{hr}$. The assumptions made in determining the additional exposures were presented in section 3.9.1. The analysis yielded the results shown in Table 3.9-1b for the three alternatives for ash disposition: placement in a high integrity container (HIC), solidification with cement, or solidification with a polymer. In the case of ash disposition using HICs, the off-gas system byproducts were solidified using the polymerization option.

TABLE $3.9-1 \mathrm{~b}$

FACILITATION CASE DISPOSAL OF COMPACTED WASTE

$\begin{array}{lccc}\text { Burial } & \text { Net Volume } & \text { Total } & \text { Exposure } \\ \text { Volume } & \text { Reduction } & \text { Cost } & \text { Decrease: } \\ (\mathrm{cu} f t) & \text { Ratio } & (\$) & \text { manRem } / \mathrm{Yr}\end{array}$

PWR

\begin{tabular}{|c|c|c|c|c|}
\hline $\begin{array}{r}460 \\
1446 \\
723\end{array}$ & $\begin{array}{r}22 \\
7 \\
14\end{array}$ & $\begin{array}{l}\text { (HIC) } \\
\text { (Cement) } \\
\text { (Polymer) }\end{array}$ & $\begin{array}{l}584,000 \\
567,000 \\
587,000\end{array}$ & $\begin{array}{l}(0.65) \\
(1.02) \\
(0.75)\end{array}$ \\
\hline
\end{tabular}

BWR

$\begin{array}{lllll}1088 & 22 & \text { (HIC) } & 1,373,600 & (1.35) \\ 3418 & 7 & \text { (Cement) } & 1,320,300 & (1.97) \\ 1709 & 14 & \text { (Polymer) } & 1,378,400 & (1.52)\end{array}$

3.9.5 Conclusions

The analysis produced substantial savings in wastes as a result of the incineration process except in the case of incineration of the byproducts (off-gas scrub liquor wastes not shown), where the initially generated wastes and the resulting volume reduction were not sufficient to produce a net cost savings. Otherwise, incineration yielded both a savings in disposal wastes and net 
disposal cost over the base scenario. The analysis for the BWR case was slightly more favorable on a total dollars per cubic foot basis because of the larger initial wastes over which to distribute the fixed system costs. This is accomplished either by minimizing the volume of solidification binder needed, e.g.,a polymerization process instead of cement encapsulation, and/or the use of high integrity containers for that portion of the waste not requiring stabilization. Table 3.9-2(a\&b) summarizes the results of this analysis.

TABLE $3 \cdot 9-2 a$

\section{INCINERATION : PWR}

\begin{tabular}{lcccc}
$\begin{array}{l}\text { Evaluation } \\
\text { Category }\end{array}$ & $\begin{array}{c}\text { Base } \\
\text { Case }\end{array}$ & $\begin{array}{c}\text { Facilitation } \\
\text { Case }\end{array}$ & $\begin{array}{c}\text { Net } \\
\text { Reduction }\end{array}$ & $\begin{array}{c}\text { Percent } \\
\text { Reduction }\end{array}$ \\
\hline $\begin{array}{l}\text { Radiation } \\
\text { Exposure, } \\
\text { manRem }\end{array}$ & $0.4 \emptyset$ & $1.05-1.42$ & $(\emptyset .65-1.02)$ & $(163-255)$ \\
$\begin{array}{l}\text { Waste volume, } \\
\text { cu ft }\end{array}$ & 10,125 & $464-1444$ & $9661-8681$ & $95-14$ \\
$\begin{array}{l}\text { Cost in } \\
\text { Thousands }\end{array}$ & 655 & $567-588$ & $88-67$ & $87-9 \emptyset$
\end{tabular}

TABLE $3 \cdot 9-2 b$

INCINERATION : BWR

\begin{tabular}{llccc}
$\begin{array}{l}\text { Evaluation } \\
\text { Category }\end{array}$ & $\begin{array}{c}\text { Base } \\
\text { Case }\end{array}$ & $\begin{array}{c}\text { Facilitation } \\
\text { Case }\end{array}$ & $\begin{array}{c}\text { Net } \\
\text { Reduction }\end{array}$ & $\begin{array}{c}\text { Percent } \\
\text { Reduction }\end{array}$ \\
\hline $\begin{array}{l}\text { Radiation } \\
\text { Exposure, } \\
\text { manRem }\end{array}$ & $\emptyset .48$ & $1.05-2.45$ & $(\emptyset .57-1.97)$ & $119-41 \emptyset$ \\
$\begin{array}{l}\text { Waste volume, } \\
\text { Cuft }\end{array}$ & 23,929 & $1085-3418$ & $22844-20511$ & $96-86$ \\
$\begin{array}{l}\text { Cost in } \\
\text { Thousands }\end{array}$ & $1,42 \emptyset$ & $41.7-99.7$ & $1378.3-1320.3$ & $97-93$
\end{tabular}




\subsection{WÓRKER TRAINING}

3.10.1 Description

Worker training is a broad category of administrative procedures and contamination control measures specifically directed at reducing exposure and wastes generated. A well planned prerequisite training program developed in accordance with ALARA principles and waste generation reduction will be effective in reducing direct and collateral exposures and wastes. Direct exposures are those associated with the unavoidable activities of cutting pipe, capping components, packaging, etc. Collateral exposures are those associated with preparation and setup, worker inefficiency, supervision, radiological monitoring and post-activity cleanup. similarly, direct waste generation is from the unavoidable packaged volume of activated/contaminated materials for burial. Collateral wastes are those from cutting supplies, plastic sheeting, absorbant materials, cutting chips/swarf, cross-contamination of adjacent clean materials, poor housekeeping, etc. An effective comprehensive worker training program can reduce these collateral exposure and wastes.

\subsection{0 .2 objective}

The objective of this technique is to identify the major topics of an effective worker training program for crew and supervisory staff to establish a responsible, conscientious worker attitude towards reducing exposures and wastes.

\subsubsection{Approach and Methodology}

The approach for this technique is not to perform an activity-by-activity reduction analysis, but to describe the important elements of a training program. Specific decommissioning tasks are not identified, nor will a particular exposure level or waste reduction factor objective be established. The training topics address individually small contributions to the total exposure or waste volume. When they are collectively applied over the entire decommissioning program, a significant reduction in collateral exposures and wastes can be achieved.

The major topics of a worker training program for exposure reduction are shown in Table 3.10-1a, and for waste reduction in Table 3.10-1b. Program instruction would be a combination of prerequisite worker indoctrination, periodic refresher lectures and 


\section{PROGRAM ELEMENTS: EXPOSURE REDUCTION}

\section{Radiological protection}

A. Protective clothing

- single layer

- double layer

B. Respirators

- fit and test - loss of productivity

C. Personnel Monitoring

- location on body relative - pencil dosimeters to source

- TLDs

D. Access Controls

- step-off pads

E. Shielding

- permanent - temporary/movable

\section{Contamination Controls}

A. Tenting

- major areas

- specific components

B. Ventilation

- flow directed away from - HEPA filtration worker

\section{Radiation Work Permits}

A. Protective Clothing Requirements

B. Access Requirements

C. Residence Duration Limits

\section{Facility Radiation Levels, Design and Arrangement}

A. Hot spots

- equipment - cubicles

B. Access Points

- ingress - egress 
TABLE $3 \cdot 10-1 a$

(Continued)

C. Access Controls

- control point signs

- secured doors

- work authorizations

D. Ventilation/Filtration

- location

- flow path

E. Stairs, Ladders, staging

5. Craft Skills Training

A. Preplanning Task Work

- equipment \& consumables - utilities

- access limitations

- install shielding

B. Craft proficiency

- task briefing

- task debriefing

- mockup training

\section{Critical Worker Exposure}

A. Substitution of Workers

- laborers/supervisors for setup

B. Minimize Time in Radiation Areas

7. Emergency Plans

A. Egress Route

B. First Aid Facilities 


\section{Contamination Control}

A. Tenting

- major areas - specific components

B. Ventilation

- close to source - HEPA filter

C. Use of Non-Abrasive Cutters

- minimize spread of - slow speed cutters particulate as best source

D. Avoid High Temp (Plasma Arc) Torches

- vaporizes metal, spreads - use closely placed HEPA
contamination

E. Prevent Cross-Contamination

- control ventilation - ventilate low-to-high directional flow contamination area

F. Masslinn (Tacky) Wipes

- wipe and fold technique

G. Pool Crane Immersion Policies

- contaminated crane hook

H. Use of Sleeving

- on air/gas hoses

- on electrical power/ instrumentation wires

I. Curbing/Absorbants

- container spills

J. Carry In/Carry out

- minimize wastes left

in contaminated areas

\section{Unnecessary Wastes}

A. Packing Crates in Contaminated Areas

- unpack in clean area

B. Extra spare Parts

- leave outside contamination area 
TABLE $3 \cdot 10-1 b$

(Continued)

C. Extra Plastic and wipes

- leave outside contamination area

D. Surface Preparation

- clean/paint porous items

E. Radiation Tags on Contaminated Bags

- clean bags never tagged

\section{Contain spills}

A. Maintain Spill Kit

- located at work area

B. Clean Areas Immediately

- to unrestricted use levels, if possible

C. Seal Floors

- smooth and coat high traffic floors

\section{Separate Clean From Contaminated Items}

A. Remove Clean Items First

- bag to protect surface

B. Protect Clean Areas

- bag/cover if immovable

C. Separate Laundry

- clean vs contaminated

- mildly vs heavily contaminated

\section{Filling Voids in Items for Burial}

A. Nest Pipe

- up to approximately 8" diameter

B. Eill Tanks

- with insulation, protective clothing, LSA materials 
on-the-job preplanning sessions. A program manager/ instructor would be responsible for the development of the detailed curriculum, administration of the training, and maintenance of worker training records.

A similar program is underway at the Institute for Nuclear Power Operations (INPO) in cooperation with the Atomic Industrial Forum (Ref. 3-18). This program is specifically aimed at developing a worker exposure and training data bank. A standardized training program is being developed for use by all nuclear facility owners.

3.10 .4 Cost Benefit Analysis

(None performed)

3.10 .5 Conclusions

The effectiveness of worker training in ALARA planning and radioactive waste management is well established for operating power plants. Development of this approach for decommissioning is a logical extension of a successful Good Practice. 
3.11 ON-SITE DECONTAMINATION FACILITY

3.11.1 Description

This technique was identified to effectively decrease the wastes associated with contaminated hand tools and other small miscellaneous support equipment and materials conventionally disposed of as radioactive waste. Reduction would be accomplished through decontamination.

3.11 .2 objective

The purpose of this cost benefit analysis is to determine the reduction in wastes through decontamination, and the resultant costs and exposure associated with the process.

3.11.3 Approach and Methodology

A decontamination facility equipped with commercial cleaning equipment and support services was assumed to process (decontaminate to a reusable state) tools and other small components contaminated in the dismantiing activities. The cost of this processing including capital equipment costs, labor and consumables, and the processing "recovery or reclamation" success rate were compared against the waste reduction realized, the associated cost savings in disposal and replacement. Also considered was the differential in personnel exposure from the decontamination processes.

3.11.4 Cost Benefit Analysis

3.11 .4 .1 Assumptions

1 Waste volume considered in this study consists of small hand tools such as hammers, drill bits, files, levels, saw blades, crowbars, wrenches and gages. other tools include hoses, small power tools, cables, hoists, pumps and other small miscellaneous metallic objects.

2 Proven decontamination equipment currently available to the nuclear industry is assumed for this analysis.

3 Decontamination facility arrangement is compatible with the reference power plant. No extraordinary support services are required.

4 The decontamination facility is staffed by two technicians and two laborers working one 8-hour 
shift. This is to maximize processing and tool/ equipment availability turnaround. Conventional decontamination involves a single shift but requires only two laborers to maintain the same processing rate. Both scenarios are supported by a Health Physicist.

5 National average labor rates are used (Ref. 3-4).

6 Waste disposal fees of $\$ 36$ per cubic foot of waste are used. This includes the container costs and transportation and burial ground fees.

7 Reclamation of material processed is assumed to be 95\% effective. Some material will not be compatible with available decontamination processes, or contamination levels necessary to release the item may not be achieved with the decontamination processes available.

8 The criteria for release of materials for unrestricted use is assumed to be in accordance with US NRC Regulatory Guide 1.86, Table 1 therein (Ref. 3-19).

\subsubsection{Base Case}

Up to two million dollars worth of tools and specialty items are expected to be used in a large decommissioning program. Once contaminated, these items are transferred to a holding area. Approximately $1 / 3$ of the items (power tools, electric motors, etc.) would not be suitable for conventional decontamination by water and/or detergent. Only about half of the remaining items would be decontaminated to levels allowing their return to service. Conventional processes generate a large volume of liquid effluent, on the order of five gallons of liquid per cubic foot of material treated, with only a $50 \%$ success rate (Ref. 3-2ø). In addition to the volume of unreleasable tools and materials, there is considerable treatment (e.g., filtering, demineralization, evaporation) of the effluent necessary prior to its final disposition.

In summary, conventional decontamination reclaims approximately one third of the original tool waste volume, leaving two thirds as still requiring controlled disposal. Decontamination produces an added liquid waste inventory approximately equal to 5 gallons times the original two thirds waste volume. The liquid inventory would be reduced by processing, but at a cost associated with the labor, operating equipment and consumables expended. 
3.11.4.3 Facilitation Case

A decontamination facility was assumed to be on-site in the radioactive waste processing building at the time of decommissioning either as part of the original facility or constructed during the pre-decommissioning period. In both cases, the facility was assumed to have the same capabilities. For the financial analysis, the capital cost of the facility was assumed to be incurred at the end of plant life and therefore assigned to decommissioning. A typical facility is shown in Figure 3.11-1. This facility was envisioned to be able to return approximately $95 \%$ of the contaminated material back to service. The following decontamination methods were assumed available, their use being determined by radiological profile of the items: ultrasonic cleaning, high pressure water and steam, electropolishing, and freon cleaning (Ref. 3-21).

3.11.5 Conclusions

The cost benefit analysis yielded significant savings in both the cost and waste volume categories. As expected, the increased handling and process time required in the facilitation case brought a net increase in exposure to the workforce, as summarized in Table 3.11-1. Exposures in both cases do not reflect contributions during waste processing. Cost totals include the replacement cost for unreleasable material and the capital cost for the facility (including operating expenses) is included in the facilitation case costs.

TABLE $3.11-1$

ANALYSIS: ON-SITE DECONTAMINATION FACILITY

\begin{tabular}{|c|}
\hline $\begin{array}{c}\text { Evaluation } \\
\text { Category }\end{array}$ \\
\hline
\end{tabular}

Radiation

Exposure,

20.8

41.6

$(20.8)$

$(10 \emptyset)$

man Rem

Waste Volume, $\quad 8,340$

860

$7,48 \emptyset$

$9 \emptyset$

$\mathrm{cu} f t$

cost, $\$$

$2,429,40 \emptyset$

$1,460,332$

$969, \emptyset 68$

40 
FIGURE $3.11-1$

TYPICAL DECONTAMINATION FACILITY

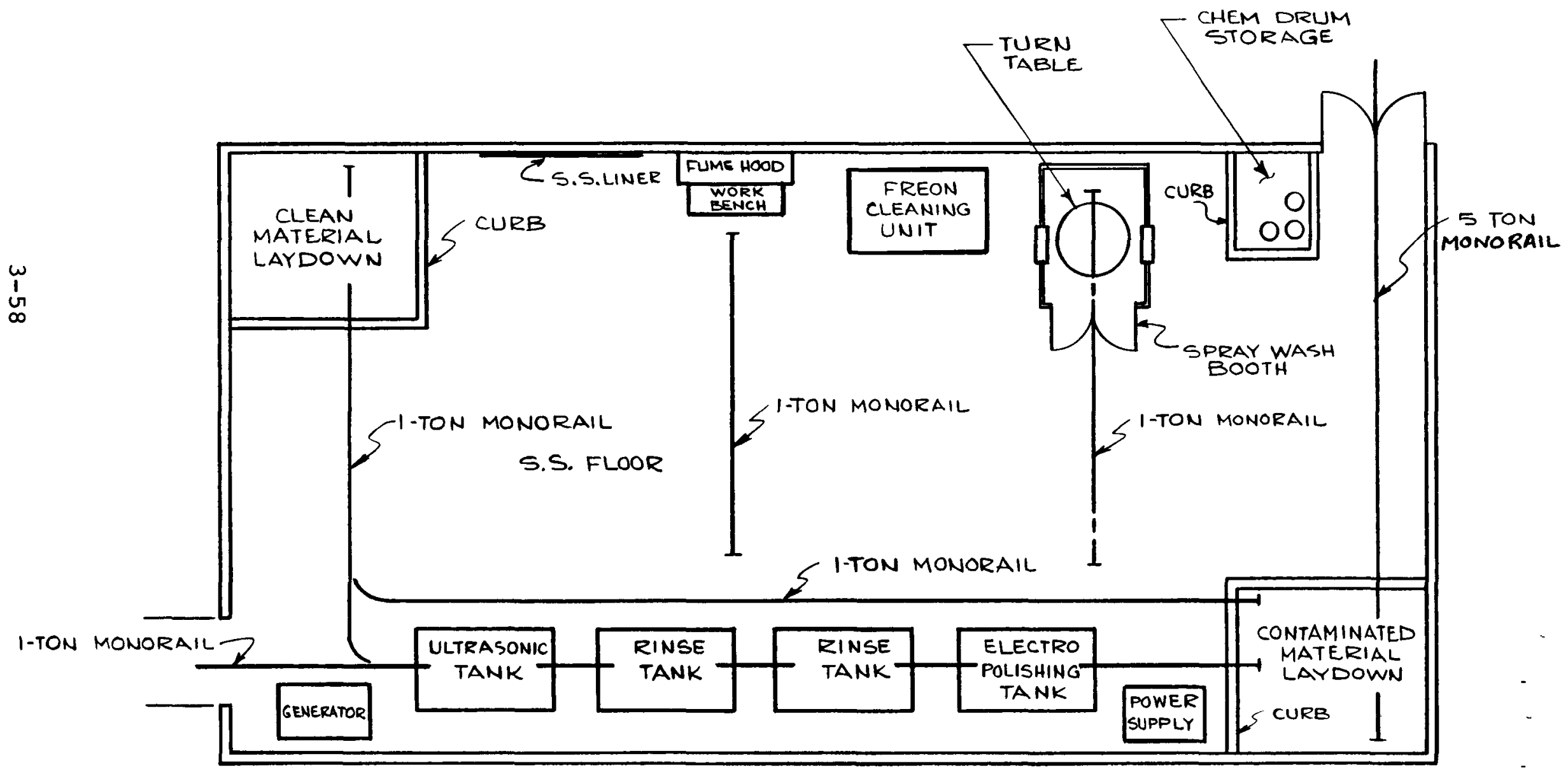


3.12 EXPLOSIVE CUTTING

3.12.1 Description

This technique proposes a reduction in the exposures incurred during the removal of piping, valves, pumps and other process equipment by reducing the duration of time spent in the radiation field(s) for workers involved in the segmentation and removal of the equipment.

Conventional methods of piping removal include oxyacetylene torches, plasma arc torches, abrasive cutting and circular cutters (milling machines). All these methods either require personnel to remain in the area throughout the cutting operation or require the installation and removal of heavy equipment with power and/or control lines to perform the cutting. Another shortcoming of conventional cutting methods is their inability to handle unusual geometries of cutting, neither nonplanar cuts through regular solids nor planar cuts through irregular solids. The technique of explosive cutting was identified as a potential technique to be applied in these situations as well as in the general component segmentation process. Figure 3.12-1 shows a sketch of an explosive cutter mounted on a pipe.

3.12.2 Objective

The objective of this cost benefit analysis was to determine if exposures could be reduced by using explosive cutting to segment piping and components in high radiation areas. Several factors were considered in evaluating explosive cutting techniques, including cutting area preparation, worker safety, potential airborne contamination during explosive segmentation, configuration of the segmented waste and its effects on optimizing waste packaging. This study considered each of these factors in determining the benefit of explosive cutting.

3.12.3 Approach and Methodology

This analysis addressed the segmentation of major piping and components located in PWR or BWR high radiation zones. Piping systems located within a PWR containment structure were considered for the PWR analysis, while piping systems located within the BWR containment boundary were considered when evaluating this technique for BWR stations. 
F IGURE $3.12-1$

EXPLOSIVE CUTTING OF PIPE

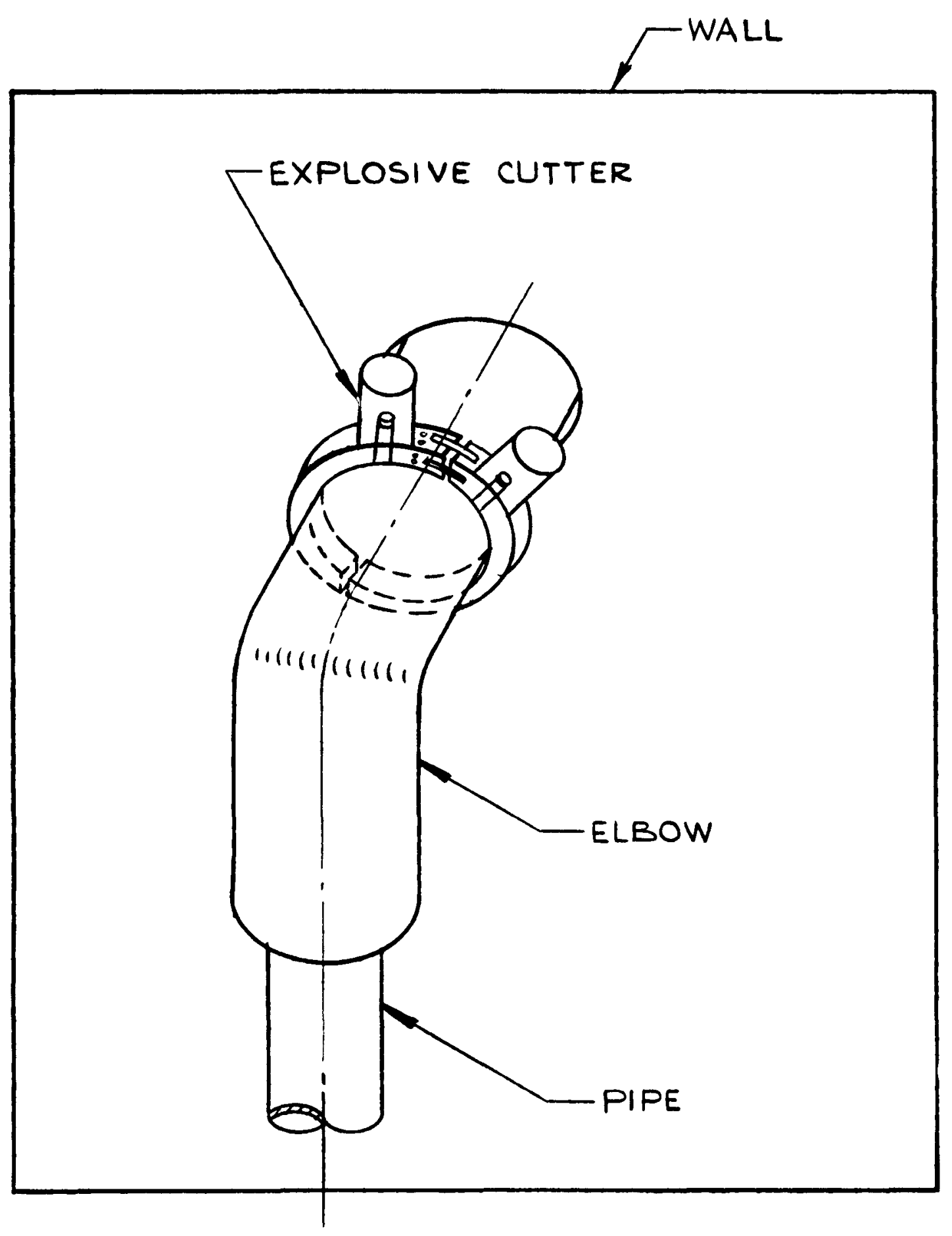


The general approach of this analysis was to identify conventional techniques used in segmenting PWR and BWR piping and components during reactor dismantling. The techniques identified in the PWR and BWR studies were assumed to be the conventional methods used to dismantle their respective stations. Dose rates, exposures, waste and cost estimates were extracted from these reference studies and represent the base case situation.

The segmentation activities were re-evaluated considering explosive cutting techniques. Collateral activities necessary to support this technique were identified and included in the analysis. These collateral activities included blasting mats installation (when necessary), contamination control tents and worker evacuation during the blasting event. Explosive cutting information provided by Jet Research and Explosive Technology provided the basis for the analyses (Refs. 3-22\&3-23).

3.12.4 Cost Benefit Analysis

3.12 .4 .1 Assumptions

1 The base case segmenting techniques used in this analysis are taken from the reference studies (Refs. $3-1 \& 3-2)$.

2 Component/piping dose rates used in the development of the base and facilitation case exposure estimates are also taken from the reference studies.

3 Explosive cutting techniques are applied only to components and piping removal activities and 1 imited to a maximum material thickness of six inches.

4 During segmentation activities using explosive cutting, all workers are evacuated from the immediate work area.

5 The additional airborne contamination generated due to the explosive cutting technique does not appreciably increase the exposure incurred by the workers.

6 The volumes and packaging configurations of the waste are assumed to be the same for both cases. 


\subsubsection{Base Case}

The segmentation techniques identified in the reference studies were used as the reference techniques for the PWR and BWR systems base case. Since these techniques are generic for both reactor types, only the major components and piping systems of the referenced PWR were considered in the detailed evaluation. The same percent savings achieved when applying the facilitation technique to a PWR station are likely to be achieved at a BWR station.

The major PWR components and piping systems considered in the base analysis were selected because of their contribution to the exposure incurred during the dismantling process. Table $3.12-1$ presents a list of the components and piping systems considered in this analysis and the total exposure incurred during these events. Note that the exposure presented in Table 3.12-1 accounts for all the dismantling activities (removal, packaging and shipping) associated with that particular decommissioning event.

These components and piping systems are assumed to be removed by conventional segmentation techniques, including arc saw, plasma torch, oxyacetylene torch, mechanical cutters and manual disassembly. Each of the techniques require some setup and cutting time, as well as the time to remove the cutting equipment from the segmented piece. Table $3.12-2$ presents the typical methods of segmentation used on the piping and components identified earlier in Table 3.12-1.

The time required to perform the setup, cutting and removal activities for each segmentation method was determined for each of the decommissioning events, as shown in Table 3.12-1. Combining the time required to perform these activities with the manpower and average exposure rates presented in the PWR study provided the exposure incurred by the workers during those activities. Table $3.12-3 a$ presents the results of the base case analysis for the five component/systems reviewed. As shown in this table, the exposure incurred during cutting equipment setup and the cutting process ranged from 18 to 36 percent of the total event dose. This dose is dependent on the dose rate and configuration of the component and methods used in the segmentation process. The remaining portion of the dose incurred was due to the time required to transfer and package the segmented components into shipping containers. 
TABLE $3 \cdot 12-1$

MAJOR COMPONENTS, PIPING SYSTEMS AND OCCUPATIONAL EXPOSURE
PWR Base Case

(a)

Occupational Exposure

Event Dose: Percent of

ManRem (b) Total (c)

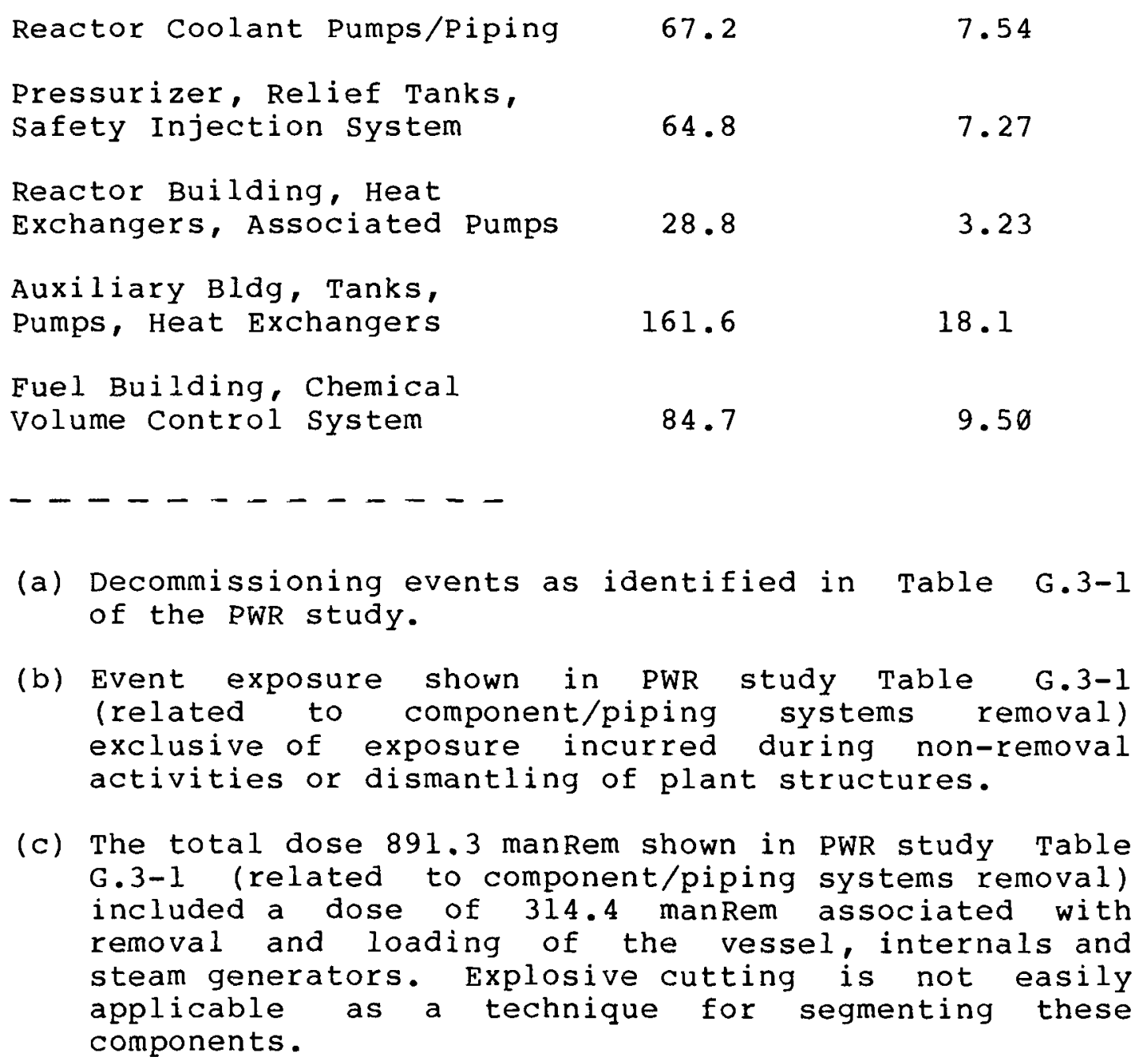


TABLE $3.12-2$

COMPONENT/PIPING SYSTEM SEGMENTATION TECHNIQUES (a)

PWR Base Case

Component/Piping

Typical Method of Segmentation

Pumps :

- Large (RCS)

Mechanical disassembly in segments

$-\quad \operatorname{Small}(<1 \emptyset, \emptyset \emptyset \emptyset \mathrm{lbs})$

Mechanical disconnection of suction, discharge lines and electrical hookups

Piping:

- 2-14" OD

- 27-31" ID

Plasma Torch

Arc Saw

Pressurizer

oxyacetylene Torch ( 8 segments)

Tanks :

- Large (Relief, Safety

Injection, Accumulators) Plasma Torch ( 8 segments)

$-\operatorname{Small}(<1 \emptyset, \emptyset \emptyset \emptyset \mathrm{gal})$

Plasma Torch (<4 $47^{\prime}$ sheets)

Heat Exchangers

Plasma Torch and removed intact

(a) Information extracted from Table G.1-1 and other sources within the PWR study. 
TABLE $3.12-3 a$

CONVENTIONAL CUTTING OF SELECTED COMPONENTS/PIPING: PWR Base Case

\begin{tabular}{|c|c|c|c|c|c|c|c|c|c|c|c|c|c|}
\hline \multirow[b]{2}{*}{ Removal Aetivity } & \multirow{2}{*}{\multicolumn{2}{|c|}{$\begin{array}{l}\text { Postulated Hours: } \\
\text { Setup/ Cutting } \\
\text { Removal Time }\end{array}$}} & \multicolumn{9}{|c|}{ Decommissioning Personnel } & \multirow[b]{2}{*}{$\begin{array}{l}\text { Event Total } \\
\text { Dose (M/Re }\end{array}$} & \multirow[b]{2}{*}{$\begin{array}{l}\text { Of Total } \\
\text { Event }\end{array}$} \\
\hline & & & $\begin{array}{l}\text { Supe } \\
\text { Avarage } \\
\text { Rate/hre }\end{array}$ & $\begin{array}{l}\text { rvlsors } \\
\text { Total } \\
\text { Hours }\end{array}$ & Dose & $\begin{array}{l}\frac{\text { Decom } C_{r}}{\text { Average }} \\
\text { Rate/hr }\end{array}$ & $\begin{array}{l}\text { ew/ Techn } \\
\text { Total } \\
\text { Hours }\end{array}$ & $\begin{array}{l}\frac{\text { Cians }}{\text { Dose }} \\
\text { m/Rea }\end{array}$ & 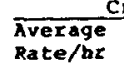 & $\begin{array}{l}\frac{1 \text { aftsm }}{\text { Total }} \\
\text { Hours }\end{array}$ & $\begin{array}{l}\text { Dose } \\
\text { M/Rem }\end{array}$ & & \\
\hline $\begin{array}{l}\text { Reactor coolant system, } \\
\text { Pumps (4) and Piping }\end{array}$ & 44.5 & 271 & 9.01 & 333.5 & 3.34 & 0.01 & 1306 & 13.86 & 0.01 & 676.5 & 6.21 & 22.61 & 33.7 \\
\hline $\begin{array}{l}\text { Pressurizer, Rellef Tank, } \\
\text { Safety injection System }\end{array}$ & 37.2 & 298 & 9.015 & 122.6 & 1.84 & 9.815 & 735.6 & 11.0 & 8.815 & 490.4 & 7.36 & 28.2 & 31.2 \\
\hline $\begin{array}{l}\text { Heat Exchangers and } \\
\text { sssociated pumps }\end{array}$ & 38.2 & 139 & 0.01 & 50.1 & 0.5 & 0.01 & 279.9 & 2.8 & 0.01 & 195.4 & 1.95 & 5.25 & 18.2 \\
\hline $\begin{array}{l}\text { Auxiliary Bldg, Tanks, } \\
\text { Pumps t Heat Exchangers }\end{array}$ & 75.6 & 141 & 0.028 & 178.4 & 5.06 & 0.029 & 929.4 & 27.64 & 0.032 & 804 & 25.65 & 58.35 & 36.1 \\
\hline $\begin{array}{l}\text { Chemical volume Control } \\
\text { System }\end{array}$ & 210 & 329 & 0.86 & 86.2 & 5.17 & 0.06 & 272.5 & 19.35 & 0.066 & 86.2 & 5.65 & 21.18 & 25 \\
\hline rotal & 405.5 & 1097 & & & & & & & & & & 127.59 & \\
\hline
\end{tabular}

TABLE $3.12-3 b$

EXPLOSIVE CUTTING OF SELECTED COMPONENTS/PIPING: PWR Facilitation Case

\begin{tabular}{|c|c|c|c|c|c|c|c|c|c|c|c|}
\hline \multirow[b]{2}{*}{ Removal Activity } & \multicolumn{9}{|c|}{ ecommissioning Personnel } & \multirow[b]{2}{*}{$\begin{array}{l}\text { Event Total } \\
\text { Dose (M/Rew) }\end{array}$} & \multirow[b]{2}{*}{$\begin{array}{l}\text { of Total } \\
\text { Event }\end{array}$} \\
\hline & $\begin{array}{l}\frac{\text { Supes }}{\text { Average }} \\
\text { Rate/hr }\end{array}$ & $\begin{array}{l}\text { Evisors } \\
\text { Total } \\
\text { Hours }\end{array}$ & $\begin{array}{l}\text { Dose } \\
\text { M/Rem }\end{array}$ & $\begin{array}{l}\text { Decom Cx } \\
\text { Averagge } \\
\text { Rate/hr }\end{array}$ & $\begin{array}{l}\text { ow/Tech } \\
\text { Total } \\
\text { Hours }\end{array}$ & $\begin{array}{l}\text { In1cians } \\
\text { Dose } \\
\text { M/Rere }\end{array}$ & $\begin{array}{l}\text { Average } \\
\text { Rate/hi }\end{array}$ & $\begin{array}{l}\text { Eaftamen } \\
\text { Total } \\
\text { Hours }\end{array}$ & $\begin{array}{l}\text { Dose } \\
\text { M/Rem }\end{array}$ & & \\
\hline $\begin{array}{l}\text { Reactor coolant system, } \\
\text { Pumps (4) and Pipling }\end{array}$ & 0.01 & 124.5 & 1.25 & 0.01 & $\$ 43.6$ & 4.43 & 0.01 & 179.3 & 1.79 & 7.47 & 14.4 \\
\hline $\begin{array}{l}\text { Pressurizer, Relief rank, } \\
\text { safety Injection system }\end{array}$ & 0.015 & 12.6 & 0.64 & 0.015 & 255.6 & 3.83 & 0.825 & 178.4 & 2.56 & 7.03 & 13.6 \\
\hline $\begin{array}{l}\text { Heat Exchangers and } \\
\text { Associated Pumps }\end{array}$ & 0.01 & 12.9 & 0.13 & 9.01 & 142.2 & 1.42 & 0.01 & 95.6 & 0.95 & 2.50 & 9.6 \\
\hline $\begin{array}{l}\text { Auxiliary Bldg, Tanks, } \\
\text { Pumps i Heat Exchangers }\end{array}$ & 0.828 & 101.1 & 2.87 & 0.029 & 197.7 & 14.81 & 0.832 & 582.9 & 16.04 & 33.72 & 24.6 \\
\hline $\begin{array}{l}\text { Chenlcal volume Control } \\
\text { system }\end{array}$ & 8.06 & 59.2 & 3.55 & 0.06 & 62.5 & 3.75 & 0.066 & 31.2 & 2.86 & 9.36 & 12.8 \\
\hline TOTAL & & & & & & & & & & 68.08 & \\
\hline
\end{tabular}


The effects of the base and facilitation cases on waste were not considered in this analysis. There should be little difference on subsequent wastes using either the base or facilitation case techniques.

\subsubsection{Facilitation Case}

The facilitation case analysis considered the use of pre-formed explosive cutters in place of the conventional cutting techniques. Recent advances in explosive cutting technology have developed broader applications for this technique. For this analysis, explosive cutting methods were assumed to replace the conventional methods identified in Table $3.12-1$ in segmenting the five PWR components/piping systems. These explosive cutting techniques offered the advantages of reduced setup and cutting time and did not require any disassembly of cutting equipment after segmentation.

However, additional precautions must be taken when using explosive cutting techniques. These precautions include blast pressure analyses, blasting mats (selected areas), increased airborne contamination following cutting, and more restrictive procedures in handling cutting tools and worker safety.

The use of explosive cutting is most effective on the segmentation of piping, separation of pumps from their suction and discharge lines, and segmentation of small, thin-walled vessels. Pre-formed explosive cutters can be easily used on these activities and offer the advantages of quicker setup time and simultaneous segmentation. As component size and material thickness increase the advantages of explosive cutting decrease.

Each of the five PWR components/piping systems were reviewed to determine the effect of explosive cutting on reducing exposure. Total doses incurred for each of the five events were calculated by replacing the base case setup and cutting time with that required by explosive cutting techniques. The average exposure rates for the facilitation technique were assumed to remain the same as the base case. Only additional time required to implement safety precautions (blast mats, blast area entry control, etc) were included in the case analysis.

Table 3.12-3b shows that an appreciable dose savings can be achieved using this technqiue. In general, this technique reduces the event dose incurred during setup/cutting effort from an average $28.3 \%$ for the base case to approximately $15 \%$ of the overall dose received 
during the facilitation case greatest exposure reduction time; explosive cutting seqmentation crews to move the segmenting process and exposure incurred during process. dismantling events. The was due to reduced cutting activities require the out of the work area during this drastically reduces the conventional cutting

\subsubsection{Conclusions}

A comparison of the analyses indicated that appreciable exposure reduction could be achieved when using explosive cutting techniques. Table 3.12-4 provides the total dose savings and costs to achieve those savings. Generally, the use of explosive cutting reduced cutting time and thus exposure hours to the decommissioning staff. The exposure incurred during setup/cutting operations decreased from 127.6 manRem to 60.1 manRem exposure. This represented a reduction of 67.5 manRem or an average of $52.9 \%$ savings in dose (associated with setup/cutting operations).

A total of approximately $37 \emptyset \emptyset$ manhours were saved when using explosive cutting for the five events reviewed. This reduction helped to reduce the overall expense associated with the purchase of pre-formed explosive cutters. The cost information presented in Table 3.12-4 presents the differences due to manhour reduction and the additional material cost when using explosive cutting. The cost for pre-formed pipe explosive cutters ranged from $\$ 17 \emptyset$ to $\$ 58 \emptyset$ per cutter (Ref. 3-22); these cutters were used on all piping ranges to a maximum of 36" dia. Specially shaped explosive cutters were used to segment the pressurizer, all tanks and support structures. These charges were capable of handing components up to 16 feet in diameter and a material thickness of less than six inches. The cost for these cutters ranged from $\$ 10.75$ to $\$ 56$ per linear foot cut, depending on material thickness. Additional costs were included for pre-forming these shaped charges to component configurations. 
TABLE $3 \cdot 12-4$

\section{ANALYSIS: BASE CASE VS EXPLOSIVE CUTTING TECHNIQUES}

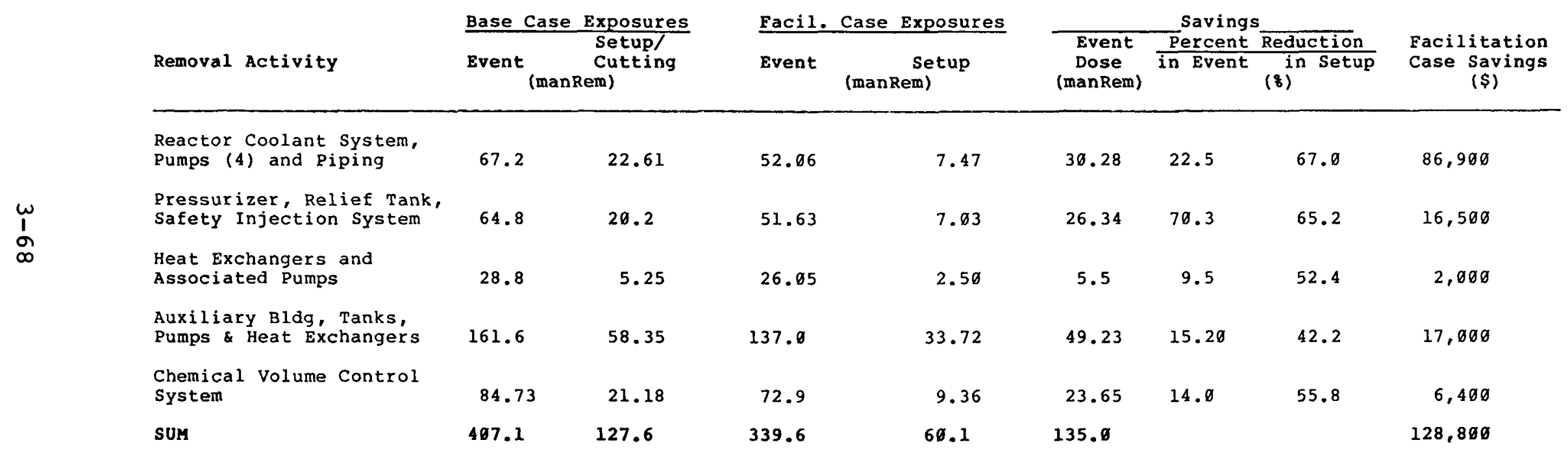


3.13 INTACT REMOVAL

3.13.1 Description

This technique was identified to reduce exposure by the intact removal and disposal of components rather than by segmentation prior to removal. The reduction in exposure is accomplished by eliminating those tasks required for the segmentation process, thereby reducing time spent in radioactive areas.

3.13.2 objective

The purpose of this cost benefit analysis is to determine the feasibility of the intact removal technique. The specific analysis is intended to quantify the exposure differential between the intact removal of components and removal by segmentation. The waste produced and implementation costs are also evaluated.

\subsubsection{Approach and Methodology}

The analysis was performed for two components that typify the various components to be removed from a nuclear plant during decommissioning, a steam generator from. a PWR and a large radwaste tank from a BWR. Intact removal and segmentation removal scenarios were evaluated for both the steam generator and radwaste tank. This involved (1) the determination of tasks required to implement each scenario and the final end products of each, and (2) the applicable components, specifications, equipment, cost rates, transportation requirements/rates and disposal rates. The radiological conditions of each work area were determined as well as the required equipment and manpower needed to accomplish each task. The exposures, resulting wastes to be disposed of, and the cost of implementation were determined for each scenario. The differential exposure, waste and cost were determined for each of the component removal scenarios to determine the viability of the intact removal techniques.

3.13.4 Cost Benefit Analysis

3.13.4.1 Assumptions

Steam Generator Case

1 Basic component sizes and plant layout arrangement are taken from the reference PWR study (Ref. 3-1). 
2 Segmentation scenario is that described in the PWR study.

3 Exposure rates are derived from data presented in NUREG/CR-1595 (Ref. 3-24).

4 Manpower requirements are derived from data in NUREG/CR-1595 and NRC PDR A4.10.1 (Ref. 3-25).

5 Duration and manpower requirements for welding not given in References 3-24 \& 3-25 are determined from R.S. Means (Ref. 3-4).

6 A dose rate reduction factor of ten is assumed during cutting when high water level is maintained in the steam generator. This dose reduction technique is applied whenever applicable for either scenario.

7 The differential manRem exposure is based on the manhours of workers performing primary activities and does not consider those of support workers such as Health Physicists and QA technicians.

Radioactive Waste Tank Case

1 Segmentation scenario is that described in the BWR study for general component removal (Ref. 3-2).

2 Exposure rates are derived from data presented in the BWR study; duration, manpower and equipment requirements are determined from R.S. Means (Ref. $3-4)$.

3 Basic component and plant layout specifications are derived from the BWR study.

4 Transportation costs are derived from Tri-state Motor Transit rates (Ref. 3-8); a $50 \emptyset \mathrm{mile}$ one-way trip is assumed.

5 Disposal is assumed to be at the Chem-Nuclear Barnwell site; disposal fees are determined from their rate schedules. (Ref. 3-7).

\subsection{3 .4 .2 Base Case}

Steam Generator Removal

The scenario for the conventional removal of a steam generator consists of (1) removal of area obstructions and erecting scaffolding, local shielding and containment enclosure setup, (2) severing the steam generator from the reactor coolant piping, and then (3) 
cutting the generator into eight segments. This is accomplished by making seven circumferential cuts in the outer shell with a "Trav-L-Cutter" remotely operated cutting tool, cutting the steam generator internals with an oxyacetylene torch, placing the internals into their respective shells and sealing the openings of each segment with welded steel plates. Each segment is then prepared and used as its own shipping container.

Removal of the steam generator (one unit) is estimated in the PWR study to generate $8,137 \mathrm{cu}$ ft of radioactive waste requiring shipment and disposal. The total cost for removal, preparation, shipment and disposal of the generator totaled $\$ 1,097,100$. The estimated occupational exposure to segment the steam generator into eight segments is 567.3 manRem per unit.

Radioactive Waste Tank Removal

The tank chosen for removal is a liquid radwaste holdup tank. The tank is 12' in diameter and 60' long, with $\emptyset .75 "$ thick walls and an empty weight of 33 tons. The tank is segmented with oxyacetylene cutting torches. The top and bottom are cut off and then each are cut into ten pie-shaped sections. These sections are then placed into a $2^{\prime} \times 4^{\prime} \times 8^{\prime}$ (64 cu ft) LSA box. The tank is then further segmented with seven circumferential cuts. Each of these 8 cylinders is then longitudinally cut into 10 sections to yield $8 \emptyset$ sections. These pieces are then packaged into nine specially built 10'x4'x8' (total of $240 \mathrm{cu} f($ ) LSA boxes. The total burial volume is 304 cu ft.

The cost of removing the tank (segmentation, packaging and preparation of shipments) was $\$ 15,677$. The cost for disposing of 304 cu ft of waste was $\$ 11,657$. Transportation of the ten LSA boxes was $\$ 2000$. The total cost for removal, disposal and transportation was $\$ 29,334$.

The exposure for segmenting and packaging is estimated to be 3.375 manRem. This is based on an estimated 135 manhours for cutting and 108 manhours for packaging. Average exposures assume $80 \%$ of the cutting will be in a $12.5 \mathrm{mR} / \mathrm{hr}$ field and $20 \%$ in a $45 \mathrm{mR} / \mathrm{hr}$ field, and packaging in a $7.5 \mathrm{mR} / \mathrm{hr}$ field.

\subsubsection{Facilitation Case}

Steam Generator Removal

The scenario for intact removal consists of (1) removing obstructions from the area, (2) erecting scaffolding, localized shielding and containment enclosures, and 
severing the steam generator from the reactor coolant and secondary cooling piping. All openings are sealed with welded caps, the steam generator is rigged for lifting, the supports disconnected and the steam generator lifted out of its cubicle. The steam generator is then set down on a cradle, the external surfaces decontaminated and then taken out of the containment building for disposal.

Intact removal of one steam generator was found to generate 8069 cu ft of radioactive waste (not including LSA materials) requiring shipment and disposal. The total cost for removal, preparation, shipment and disposal of one intact steam generator was determined to be $\$ 1,191,328$. Exposure incurred for intact removal of the steam generator was found to be approximately 95.6 manRems, or 472 manRems less than that incurred for the segmentation scenario. Figure 3.13-1 shows a sketch of intact removal of a steam generator.

\section{Radioactive Waste Tank Removal}

The scenario for intact removal of the radioactive waste holdup tank consists of lifting the tank out of the building through an opening in the roof. The tank is located in an auxiliary building on a floor one level below the top level. Thus, for the tank to be removed a 13-foot diameter hole must be cut in the ceiling above the tank and a 14-foot diameter hole cut in the roof. The holes are cut with an oxygen burning lance. A crane is placed on the roof to lift out the cut concrete slabs and the intact tank. The crane places the tank on a flatbed truck and it is transported to the burial facility. prior to lifting out the tank, its connections are severed and all openings are sealed by welding on caps or steel plate and the exterior surfaces of the tank are decontaminated.

An option exists for intact removal of components that have large internal void volumes such as tanks. The intact tank (with its internal void volume) can be used as a shipping container for lightweight compacted LSA materials. This can be done to avoid shipping and disposal of the internal void volume.

The intact removal of the tank was found to incur 0.6 manRem of exposure. The waste volume requiring disposal was found to be $6786 \mathrm{cu}$ ft for an intact tank without LSA waste placed inside and an overall negative $348 \mathrm{cu}$ ft ( $348 \mathrm{cu} \mathrm{ft}$ credit) when LSA material is placed inside of the tank. The $348 \mathrm{cu}$ ft credit arises because the tank can hold 6651 cu ft of waste, eliminating the need for using an additional 483 cu ft for LSA boxes to 
FIGURE 3.13-1

INTACT REMOVAL OF A STEAM GENERATOR
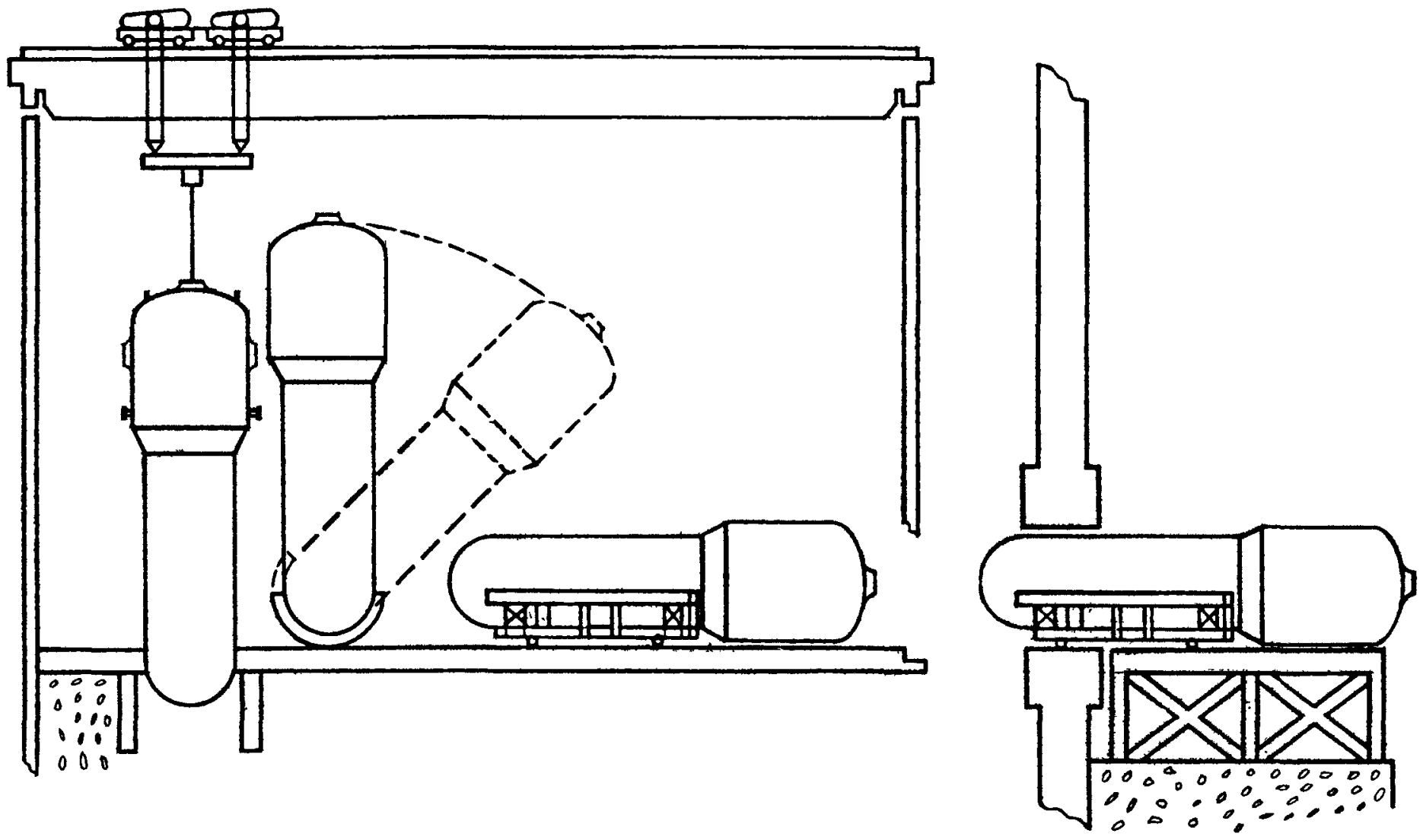
contain this waste. Therefore, $7134 \mathrm{cu}$ ft of waste are eliminated in a $6786 \mathrm{cu}$ ft container.

The cost for removing the tank intact from the building is $\$ 14,453$. This includes cutting the ceiling and roof slabs, rigging and lifting, and severing and sealing the tank. The burial charge for disposal of the tank is $\$ 147,974$ (for $6786 \mathrm{cu} \mathrm{ft}$ ). The cost for transportation of the tank (empty) is $\$ 13,989$ by rail shipment due to the large size of the tank. Thus, the total cost of intact removal, transportation and disposal of an empty tank is $\$ 176,416$.

If the tank were used as a container for LSA materials such as protective clothing, booties, plastic, paper, etc. (an option viable only for tanks with a manhole or large diameter pipe nozzles), the overall reduction in costs over separate tank and/or LSA materials disposal would be $\$ 39,775$. This reduction is derived by first adding the tank removal cost of $\$ 29,334$ to the LSA material removal cost of $\$ 198,755$ for a total tank and LSA base case cost of $\$ 228, \varnothing 89$.

The facilitation case of materials in the tank reduces this trash-only cost by (1) a savings of $\$ 143,036$ for not having to pay for disposal of the LSA materials, (2) $\$ 31,533$ for deletion of the LSA boxes that would have been needed to package the LSA materials, (3) $\$ 17,250$ saved on the weight surcharges that would have been incurred on the disposal of the boxes of LSA materials, (4) $\$ 10,386$ deleted for volume disposal savings due to the elimination of additional LSA box volume incurred when the LSA materials would have been disposed of separately, and (5) $\$ 13,800$ eliminated by not having to ship the materials separately. These savings are only moderately offset by the additional cost of $\$ 11,039$ to ship a heavier loaded tank, $\$ 1 \emptyset, \emptyset \emptyset \emptyset$ for additional bracing needed to support the more massive load during transport, and $\$ 6,652$ of weight surcharges for disposal of the heavier tank. Thus, when those modifying factors $(-\$ 188,314)$ are compared to the original cost of $\$ 228,089$ for removal, transportation and disposal of tank and materials separately, a reduction of $\$ 39,775$ results. (Note: the cost credit obtained from the 348 cu ft net waste volume saving is included in this cost.)

3.13.5 Conclusions

The results of this cost benefit analysis are shown in Table 3.13-1. In general, there will be an exposure reduction to decommissioning workers due to intact removal of components. However, the magnitude of 
TABLE $3.13-1$

ANALYSIS: INTACT REMOVAL

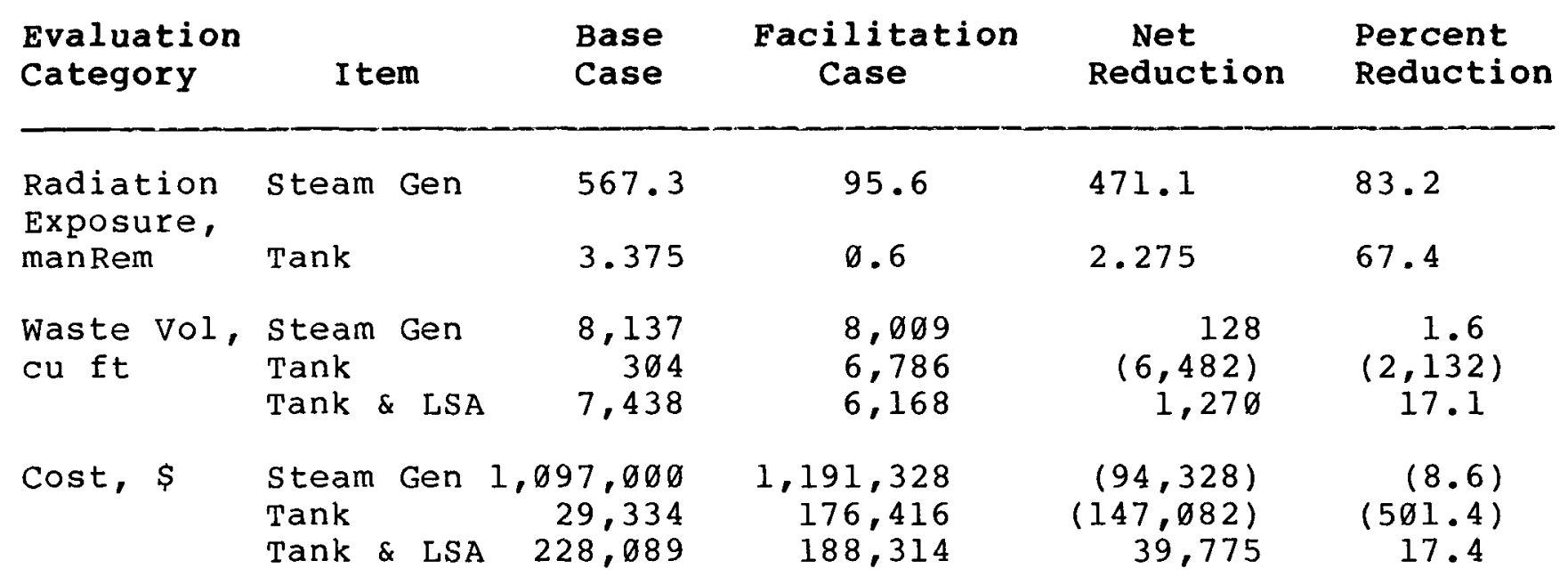

exposure reduction is highly dependent on the nature of the component to be removed (i.e., size, weight, configuration, location). In the case of significantly radioactive components (such as steam generators), the elimination of high radiation tasks required for disassembly or segmentation can provide substantial reductions in personnel exposure. The cost benefit analysis performed on the model steam generator showed that an exposure reduction of approximately 472 manRem could be realized by the intact removal of one steam generator.

It must be noted that the degree of exposure reduction is dependent upon radiological conditions and the exposure manhour reduction. These factors are in turn dependent upon the configuration of the generator and the design/operating history of the plant; thus, the degree of reduction may vary greatly from plant to plant.

Elimination of segmentation activities in low radiation fields and/or easily segmented components may have less of an effect. In the case of a large waste tank, the cost benefit analysis showed a reduction of 2.8 man Rem by intact removal instead of by segmentation. While this is a very modest reduction compared to that of the steam generator, it does represent a $67.4 \%$ reduction in exposure over that of the segmentation technique. The potential exposure reduction by intact removal is dependent upon the particular radiological conditions present and the nature (size, weight, configuration and location) of the component. 
In general, there is no specific trend regarding 'waste reduction when implementing this technique. A decrease or increase in wastes caused by intact removal is highly dependent upon the nature of the component. In the case of a steam generator, when segmented it will have a disposal volume only slightly greater in volume (1.6\%) than that of an intact steam generator. The only volume decrease in intact removal is the elimination of additional volume due to the welded steel plates sealing the openings of each segment.

In the case of a large waste tank, with its large internal void volume, intact removal (and disposal) preserves this void volume. Segmentation would eliminate this void volume and would reduce the overall waste significantly (by $6482 \mathrm{cu}$ ft for a $5 \emptyset, \emptyset \emptyset \emptyset$ gal tank). An alternative, allowing for the exposure reduction benefit of intact removal without its large waste volume preservation, would be to remove the $5 \emptyset, \varnothing \emptyset \emptyset$ gal tank intact and then use the tank with its internal void as a shipping container for light weight compacted LSA materials. Thus, while the volume of the tank is reduced, "volume credit" is obtained by not having to dispose of the LSA materials separately. This offsets the intact removal technique's nonreduction of waste.

The practicality of this approach is questionable considering the difficulty of transporting a 12-foot diameter, 60-foot long tank on the highways. It would require special routing, oversize permits, escorts, etc. Furthermore, the packing density of materials would probably be low and perhaps not worth the effort. Trash-loading may be beneficial for smaller, transportable tanks.

A cost benefit analysis of this alternative has shown that the volume of the intact tank is more than offset (by $127 \emptyset \mathrm{cu} f t$ ) when the tank is used as a container for LSA materials. This is because the volume of the LSA boxes needed to ship the LSA materials separately exceeds the volume of the intact tank outer shell.

Implementation of the facilitation technique produced variable effects on the implementation costs of cases analyzed. They were dependent upon the exact nature of the item being removed. In the case of the steam generator, intact removal was $8.6 \%$, or $\$ 94,228$ more costly than removal by segmentation. This increase in cost does not reflect the slight cost saving that would be realized due to the decrease in waste. 
In the case of the $5 \emptyset, \emptyset \emptyset \emptyset$ gallon radwaste tank, intact removal and disposal (if the tank were left empty) would cost $\$ 147, \emptyset 82$ more than that of removal by segmentation. This extreme increase in cost is caused soley by the cost of disposal and transportation of the large volume of the intact tank. The actual costs for tank removal, intact or segmented, are roughly comparable. If the tank were removed intact and used as a container for LSA materials, the $\$ 147, \emptyset 82$ excess cost of intact removal would be more than offset by the disposal cost savings due to the elimination of the LSA box volumes that would have been used for the packaging of the LSA materials and the LSA trash itself. Thus, a cost reduction of $\$ 39,775$ is possible. 
3.14 RAIL AND BARGE SHIPMENT OF NSSS RADIOACTIVE WASTÉ

3.14.1 Description

The technique of intact removal and disposal of a PWR/ BWR nuclear steam supply system (NSSS) was evaluated as a viable means of reducing exposures and subsequent wastes. The options of rail or barge shipment were evaluated as alternatives to transporting the highly activated/contaminated components to regional burial facilities.

3.14.2 Objective

The objective of this cost benefit study is to determine whether a reduction in exposures and wastes would occur when disposing of NSSS components considering rail or barge as a means of transporting contaminated/activated components to burial. These alternatives offer the advantages of shipping larger NSSS segments to burial. This concept has the potential of reducing exposure to workers removing these components and public exposure during radwaste shipping.

3.14.3 Approach and Methodology

The analysis involved the activities to remove, package, ship and bury NSSS components for the 1100 MWe reference PWR and BWR stations. The PWR NSSS components considered in this analysis included:

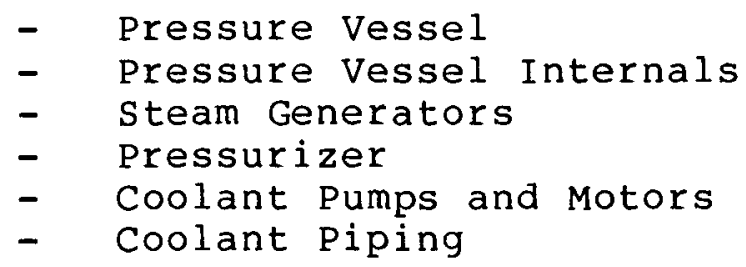

NSSS components considered for the BWR case included:

- Reactor Vessel and Internals

- Recirculation Pumps

- Recirculation Piping

- Reactor Water Cleanup System (RWCS)

- Residual Heat Removal System (RHR)

- Control Rod Drive Mechanisms (CRDM)

- Turbine

The general method of approach was to identify the dismantling activities (sequence, manpower, tooling) necessary to remove, package and ready NSSS components for burial. The dismantling activity descriptions provided in the reference studies were considered to be the base case scenario. Modified dismantling activity 
sceharios were developed considering the subsequent radwaste shipping using either rail or barge. These modified dismantling activities took into account the larger transportation load limits that are allowed when shipping by rail or barge. It is eveident that such shipping to a regional compact site may not be within $1 \varnothing$ miles and an appropriate increase in mileage may be necessary. Actual exposures, wastes and costs were calculated for each scenario and compared to determine the actual benefit of the technique.

\subsubsection{Cost Benefit Analysis}

\subsubsection{Assumptions}

The following is a list of assumptions used in performing the cost benefit analysis for this facilitation case.

1 The NSSS component information used as the basis for this cost benefit analysis is taken from the reference studies (Ref. $3-1$ and 3-2).

2 Base case dismantling activities, wastes and exposures are presented in detail in the reference studies. Base case costs are based on these reports but modified to represent 1984 dollars.

3 Facilitation case exposure estimates are based on the component dose rates provided in the reference studies.

4 Radioactive waste disposal fees are calculated using the Chem-Nuclear Systems, Inc. 1984 Burial Rate Schedule (Ref. 3-7).

5 Truck transportation fees are based upon published fees stated in the Tri-state Motor Transit Rate Schedule (Ref. 3-8).

6 Commercially available shielded shipping casks are used to ship all activated NSSS component segments to burial.

7 One-way shipping distances used in this analysis

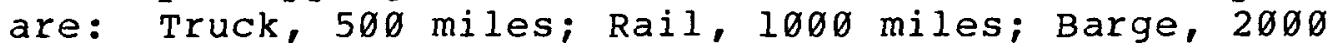
miles.

8 Rail and barge facilities are assumed to be located within a 10 mile radius of the station and regional burial facilities. If a specific site is identified for disposal that does not have a rail siding or barge dock, an estimate of 20 miles or more may be necessary. 
9 Rail and barge transportation fees are based upon published rates (Refs. $3-7 \& 3-8$ ) or personnel communications with rail or barging companies.

\subsubsection{Base Case}

The reference studies present the base case activities for dismantling the NSSS components of the 1110 MWe reference PWR and BWR. These studies assume that all components are segmented, packaged and transported by truck to burial.

For the PWR system, the general dismantling sequence would be to first segment the pressure vessel internals underwater into pieces that would fit into special shielded casks. Following the dismantling of the internals, the pressure vessel head, cylinder walls and vessel bottom would be segmented in air and loaded into either shielded casks or LSA boxes depending on activation/contamination levels of the segments.

The shielded shipping cask and transportation limitations were the controlling factors used in selecting the vessel/internal segmentation pattern. Table 3.14-1 presents the types of containers used in the PWR study and their limitations. Containers were selected to meet the shipping and packaging requirements set forth in (1) Code of Eederal Regulations, Title 49, Parts 170-199the DOT regulations governing the transport of hazardous materials, and (2) IøCFR71, the NRC regulations governing the packaging and shipping of radioactive materials. These container limitations were used to determine the dismantling method of approach, the manpower and special tooling requirements, and the wastes and exposures associated with removing the vessel and internals.

The remaining components (steam generators, pressurizer, reactor coolant pumps and piping) would be dismantled in a fashion similar to the pressure vessel. These components would be segmented into pieces to meet road weight and access limitations set forth by each state's Department of Transportation.

In general, the vessel would be segmented in 110 pieces, loaded into LSA containers generating approximately $7,800 \mathrm{cu} f t$ of waste; the staff/crew would incur approximately 78 manRem of exposure. The internals would be segmented into 631 pieces and loaded into shielded cask liners. This activity generates approximately $8,80 \emptyset \mathrm{cu} f t$ of waste with approximately 101 manRem of exposure incurred. Note that exposures incurred during this activity is not sufficiently 
TABLE $3 \cdot 14-1$

\section{LIMITATIONS ON NSSS RADWASTE USING TRUCK TRANSPORT}

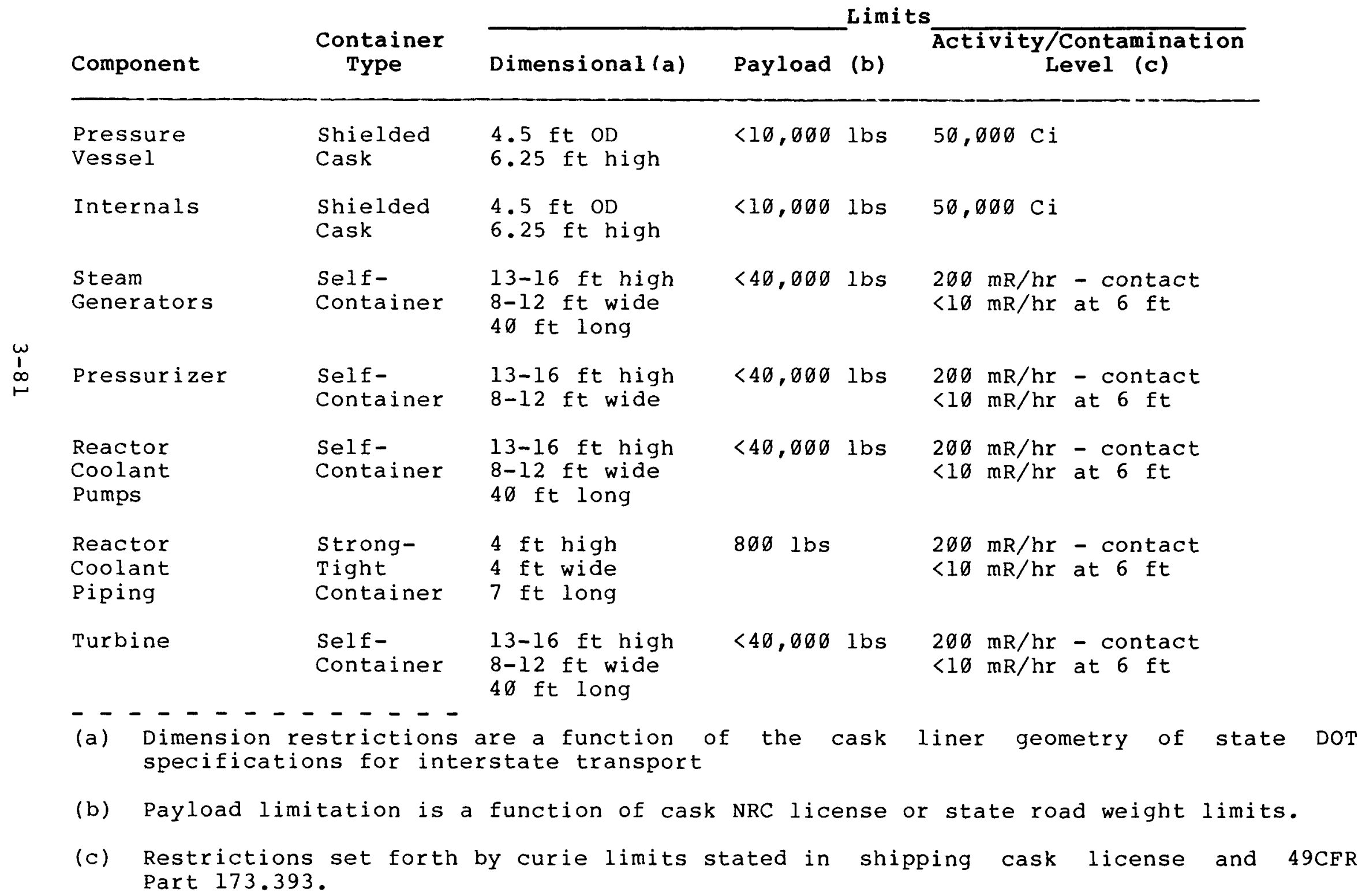


greater than vessel segmentation because àl internal segmentation/packaging is performed underwater, thus reducing exposure.

Each of the four steam generators and pressurizer would be segmented into 8 pieces and used as its own shipping container. This method of dismantling minimized the waste generated but developed additional manRem exposure because of the segmentation effort.

Each reactor coolant pump would be disassembled into three pieces (motor, impeller casing), all orifices sealed and the segments shipped as self-containers. The coolant piping $(2,467$ feet $)$ would be segmented into 274 pieces and placed in LSA boxes.

Table 3.14-2a presents the summary of the base case analysis for a PWR system and presents total waste generated, exposures incurred and the total costs for dismantling all the NSSS components. Note that the 454 manRem exposure and 49,062 cu ft of waste generated during this dismantling activity represented approximately $42 \%$ and $8 \%$ of the total, respectively.

The BWR NSSS components dismantling sequence is similar to that of the PWR system. Reactor vessel internals are segmented underwater and packaged in shielded shipping casks. The reactor vessel itself is segmented in air with the activated vessel walls being shipped in shielded casks and the remainder of the vessel in LSA containers. As with the PWR system, the BWR vessel and internals segmentation patterns are a function of the truck transport limits.

The remaining components (recirculation pumps, piping, reactor building components and turbine) would all be appropriately segmented, packaged in strong tight (Ref. 3-3) containers and trucked to burial. Table 3.14-2b presents the results of the BWR base case analysis. A total of 454 shipments were necessary to move the NSSS components to burial. This results in the generation of $95,945 \mathrm{cu} f t$ of waste and 736.8 manRem of exposure. Dismantling of BWR NSSS components represented approximately $40 \%$ of the total exposure and $14.3 \%$ of the waste generated during the total decommissioning process.

\subsubsection{Facilitation Case}

This case considered the use of either railway or barge as the means of shipping the components to burial. Larger shipping casks and heavier payloads can be 
TABLE $3 \cdot 14-2 a$

TRUCK SHIPMENT OF NSSS COMPONENTS: PWR (a)

\begin{tabular}{|c|c|c|c|c|c|c|c|c|}
\hline & Component & $\begin{array}{l}\text { Weight (b) } \\
\text { (1b) }\end{array}$ & $\begin{array}{l}\text { Estimated } \\
\text { Radioactivity } \\
\text { (Ci) }\end{array}$ & $\begin{array}{l}\text { No. of } \\
\text { Pieces }\end{array}$ & $\begin{array}{l}\text { No. of } \\
\text { Shipments }\end{array}$ & $\begin{array}{l}\text { Occupational } \\
\text { Exposure (c) } \\
\text { (Man-Rem) }\end{array}$ & $\begin{array}{l}\text { Radioactive Waste } \\
\text { Burial volume (d) } \\
\text { (cu } f t)\end{array}$ & $\begin{array}{l}\text { Cost for Removal, } \\
\text { Pkg, shlp, Buxy (e) } \\
(\text { s) }\end{array}$ \\
\hline 1. & $\begin{array}{l}\text { RPV (Head, Wall, } \\
\text { Bottom) }\end{array}$ & 875,500 & $<19,198$ & 110 & 78 & 78 & 7,800 & $12,750,600$ \\
\hline 2. & $\begin{array}{l}\text { Vessel Internals: } \\
\text { (Core support plates/ } \\
\text { Barrel/shroud, Thermal } \\
\text { Shield, etc.) }\end{array}$ & 421,100 & $<4,821,520$ & 631 & 88 & 200.4 & 8,800 & Included above \\
\hline 3. & Steam Generators (4) & $2,752,000$ & & 32 & 32 & 144 & 21,362 & $4,388,400$ \\
\hline 4. & Pressurizer & 195,000 & & 8 & 8 & 64.8 & 3,600 & 253,800 \\
\hline 5. & Reactox Coolant Rumps & 752,800 & & 12 & 12 & 67.2 & 4,200 & 554,250 \\
\hline 6. & $\begin{array}{l}\text { Reactor Coolant Piping } \\
\text { rotal }\end{array}$ & $\begin{array}{r}222,000 \\
5,217,608\end{array}$ & $<4,849,719$ & $\begin{array}{r}274 \\
1,067\end{array}$ & $\begin{array}{r}7 \\
201\end{array}$ & $\begin{array}{l}\text { Included above } \\
154.4\end{array}$ & $\begin{array}{r}3,300 \\
49,062\end{array}$ & $\begin{array}{r}180,600 \\
18,126,250\end{array}$ \\
\hline
\end{tabular}

TABLE $3.14-2 \mathrm{~b}$

TRUCK SHIPMENT OF NSSS COMPONENTS: BWR (f)

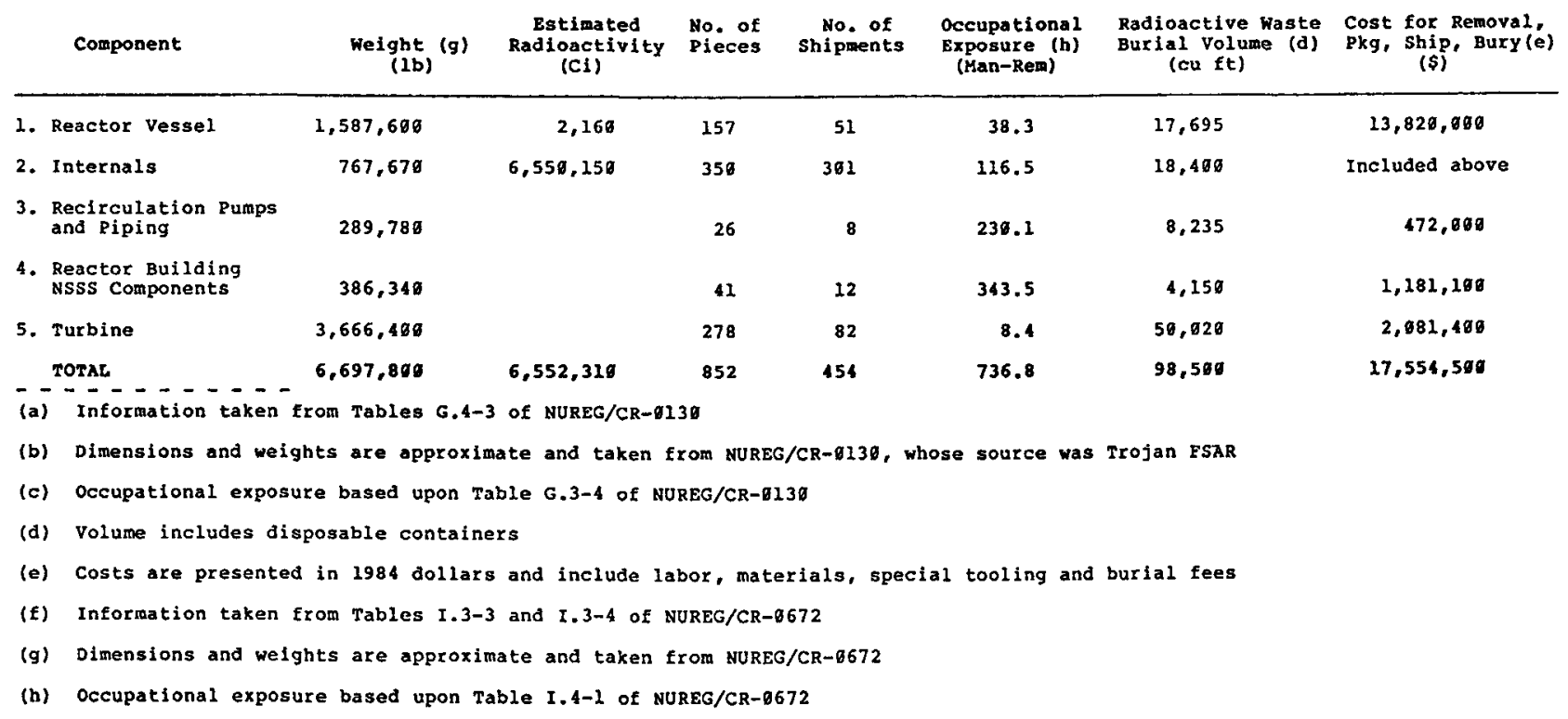


specified when using these alternative means 'of' radwaste shipment. As such, NSSS component segmentation would be required; this subsequently means a possible reduction in exposure (shorter component cutting time) and waste (reduction in packaging inefficiencies).

Commercially available railcar casks were selected as the means for transporting the activated components on both railway and barge. Two types of casks were used in the analysis: (1) General Electric IF-3øø Railcar Cask (Ref. 3-26) and (2) Chem-Nuclear Systems, Inc. CNS 8-120 (Ref. 3-1Ø). These casks were selected considering their payload, liner capacities and licensed curie limits versus the configurations of the component segments requiring cask shipment.

The contaminated NSSS components were segmented and/or shipped intact. The criteria used to determine whether a component required segmentation were either payload or dimension restricted. Table 3.14-3(a\&b) presents the transporation limits used in determining the dismantling activities required when shipping components on rail or barge.

Reference PWR

Based on the rail or barge transport limitations, several of the NSSS components were removed intact and resulted in reduced removal time and thus reduced exposure. For the PWR, the analysis assumed that the steam generators, RC pumps, pressurizer and piping were removed in one piece. The pressure vessel size and activity still required segmentation. However, the number of vessel pieces was reduced because of the less restrictive transport regulations. Table 3.14-4a presents the summary of the analysis of the facilitation case based on shipping by rail. The entire PWR NSSS components would be shipped on two special train shipments.

The pressure vessel head and bottom would be shipped intact with openings secured by steel plate. The vessel, cylinder wall and nozzle band region would be segmented. Five nozzles would be placed within the vessel head and bottom shipping packages. The remaining three nozzles would be shipped in CNS 8-120 shipping casks. A schematic of the vessel segmentation is presented in Figure 3.14-1 showing the segmentation pattern required to meet cask packaging configurations.

All vessel internals would be segmented/loaded into a total of 32 IF-3øø shipping casks. The liners would be 
TABLE $3.14-3 a$

LIMITATIONS ON NSSS RADWASTE USING RAIL/BARGE TRANSPORT: PWR

\begin{tabular}{|c|c|c|c|c|c|c|}
\hline \multirow[b]{2}{*}{ Component } & \multirow[b]{2}{*}{$\begin{array}{c}\text { Container } \\
\text { Type (a) }\end{array}$} & \multicolumn{3}{|c|}{ Shipping Container Limits } & \multicolumn{2}{|c|}{ Transport Limits } \\
\hline & & $\begin{array}{l}\text { Dimensional } \\
\begin{array}{ll}\text { (ft) } & \text { (b) }\end{array}\end{array}$ & $\begin{array}{l}\text { Payload } \\
\text { (lbs) } \quad \text { (c) }\end{array}$ & $\begin{array}{l}\text { Activity } \\
\text { (Ci) (c) }\end{array}$ & $\begin{array}{l}\text { Rail (tons) } \\
\text { (ton }\end{array}$ & $\begin{array}{l}\text { Barge } \\
\text { (d) }\end{array}$ \\
\hline $\begin{array}{l}\text { Pressure } \\
\text { Vessel }\end{array}$ & 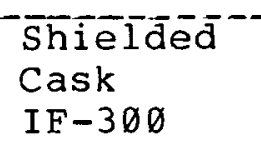 & 3.1 OD, 15 long & $\overline{31}, \overline{\varnothing \varnothing \emptyset}$ & $\begin{array}{c}\langle\bar{l}, \bar{\emptyset} \bar{\emptyset}, \bar{\emptyset} \emptyset \\
(4 \emptyset \mathrm{kw} \text { heat } \\
\text { decay) }\end{array}$ & $2 \emptyset \emptyset$ & $\overline{1} \bar{\varnothing} \varnothing$ \\
\hline & CNS $-8-12 \emptyset$ & 5.1 ID, 6 long & 18,500 & $300(550 \mathrm{R} / \mathrm{hr})$ & & \\
\hline Internals & 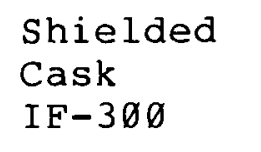 & $3.1 \mathrm{OD}, 15$ long & 31,000 & $\begin{array}{c}<1, \emptyset \emptyset \emptyset, \emptyset \emptyset \emptyset \\
(4 \emptyset \mathrm{kw} \text { heat } \\
\text { decay })\end{array}$ & $20 \emptyset$ & 1700 \\
\hline St Generators & Intact & $16 \mathrm{OD}, 60$ long & - & - & $2 ø \emptyset$ & 1700 \\
\hline Pressurizer & Intact & 16 OD, $6 \emptyset$ long & - & - & $2 \varnothing \emptyset$ & 1700 \\
\hline $\begin{array}{l}\text { Reactor Coolant } \\
\text { Pumps }\end{array}$ & Intact & 16 OD, 60 long & - & - & 200 & 1700 \\
\hline $\begin{array}{l}\text { Reactor Coolant } \\
\text { Piping }\end{array}$ & $\begin{array}{l}\text { Self- } \\
\text { Contained }\end{array}$ & $\begin{array}{l}16 \text { high, } 12 \text { wide, } \\
6 \varnothing \text { long }\end{array}$ & - & - & $2 \not \emptyset \emptyset$ & 1700 \\
\hline
\end{tabular}

(a) Casks identified are commercially available; openings of components removed in one piece will be covered with steel plates to reduce exposure.

(b) Dimensional limitations represent cask liner geometry. For those components removed in one piece, the dimensions represent restrictions for railcar passage to a burial facility.

(c) Payload and activity limits set forth in specific NRC shipping cask license.

(d) Payloads assume use of standard heavy duty rail flat cars or ocean-going barges. 
TABLE $3.14-3 b$

LIMITATIONS ON NSSS RADWASTE USING RAIL/BARGE TRANSPORT: BWR

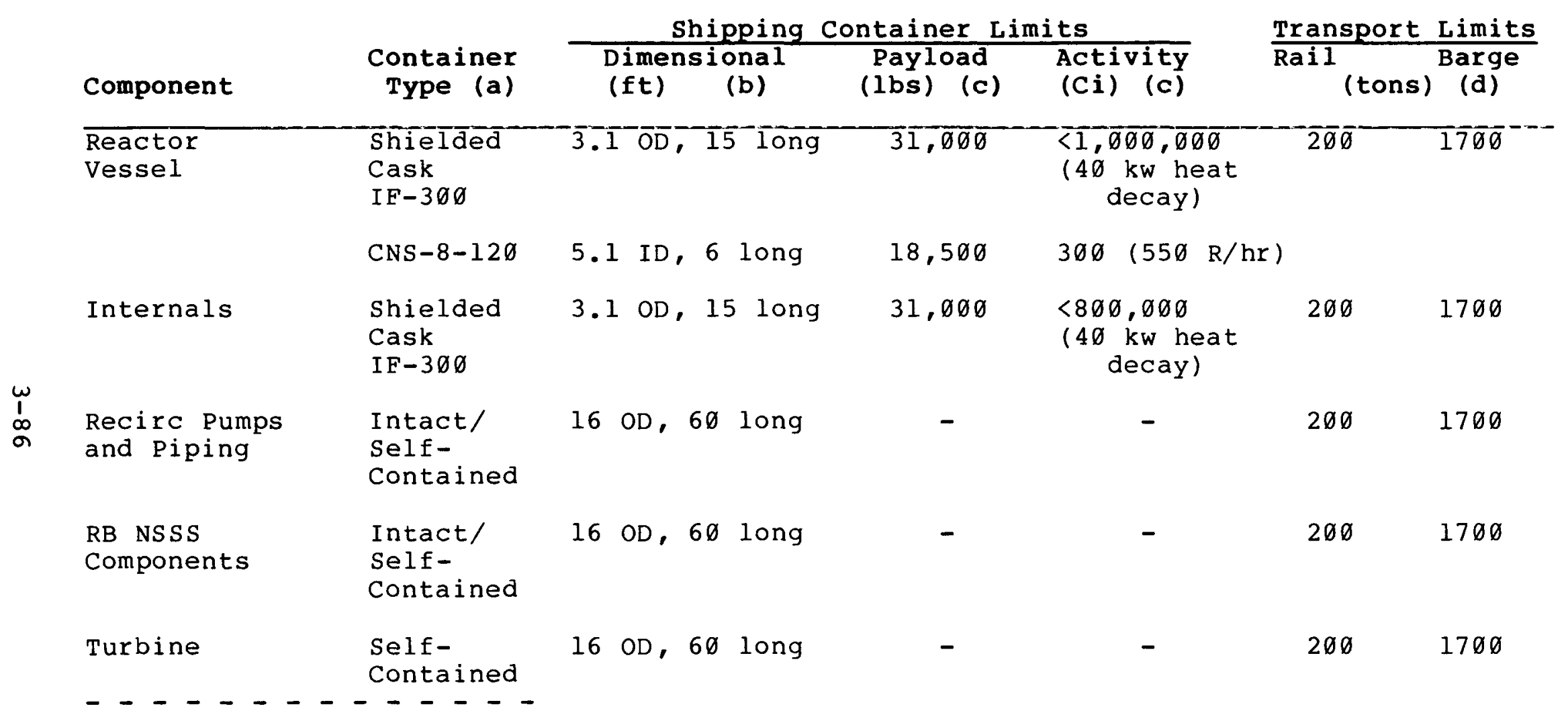

(a) Casks identified are commercially available; openings of components removed in one piece will be covered with steel plates to reduce exposure.

(b) Dimensional limitations represent cask liner geometry. For those components removed in one piece, the dimensions represent restrictions for railcar passage to a burial facility.

(c) Payload and activity limits set forth in specific NRC shipping cask license.

(d) Payloads assume use of standard heavy duty rail flat cars or ocean-going barges. 


\begin{tabular}{|c|c|c|c|c|c|c|c|c|}
\hline & Component & $\begin{array}{l}\text { Weight (b) } \\
\text { (1b) }\end{array}$ & $\begin{array}{l}\text { Estimated } \\
\text { Radioactivity } \\
\text { (Ci) }\end{array}$ & $\begin{array}{l}\text { No, of } \\
\text { Pieces }\end{array}$ & $\begin{array}{l}\text { Containers } \\
\text { pex } \\
\text { shipment }\end{array}$ & $\begin{array}{l}\text { Occupational } \\
\text { Exposure (c) } \\
\text { (Man-Rem) }\end{array}$ & $\begin{array}{l}\text { Radioactive Waste } \\
\text { Burial Volume (d) } \\
\text { (cu } f t \text { ) }\end{array}$ & $\begin{array}{l}\text { Cost for Removal, } \\
\text { Pkg, Ship, Bury (e) } \\
\text { (\$) }\end{array}$ \\
\hline & $\begin{array}{l}\text { Rev (Head, Wall, } \\
\text { Botton) }\end{array}$ & 875,500 & $<19,190$ & 93 & $14 / 2$ & 58.2 & 7,055 & $7,735,950$ \\
\hline 2. & $\begin{array}{l}\text { Vessel Internals: } \\
\text { (Core support plates/ } \\
\text { Barrel/shroud, Thermal } \\
\text { shield, etc.) }\end{array}$ & 421,100 & $<4,821,520$ & 512 & $32 / 2$ & 64.7 & 3,680 & Included above \\
\hline 3. & Steam Generators (4) & $2,752,060$ & & 4 & $4 / 2$ & 48.5 & 21,362 & $4,765,398$ \\
\hline 4. & Pressurizer & 195,060 & & 1 & $1 / 1$ & 23.3 & 2,370 & 215.600 \\
\hline 5. & Reactor Coolant Pumps & 752,000 & & 4 & $4 / 2$ & 22.4 & 4,280 & 696,800 \\
\hline 6. & Reactor Coolant Piping & 222.000 & 54840718 & $\begin{array}{r}12 \\
626\end{array}$ & $12 / 2$ & Included above & 1,920 & 230.550 \\
\hline
\end{tabular}

TABLE $3.14-4 \mathrm{~b}$

RAIL SHIPMENT OF NSSS COMPONENTS: BWR (f)

\begin{tabular}{|c|c|c|c|c|c|c|c|}
\hline Component & $\underset{(1 b)}{\text { Weight }(g)}$ & $\begin{array}{l}\text { Estinated } \\
\text { Radioactivity } \\
\text { (Ci) }\end{array}$ & $\begin{array}{l}\text { No. of } \\
\text { pieces }\end{array}$ & $\begin{array}{l}\text { Containers } \\
\quad \text { per } \\
\text { shipwent }\end{array}$ & $\begin{array}{l}\text { Oecupational } \\
\text { Exposure (h) } \\
\text { (Man-Rem) }\end{array}$ & $\begin{array}{l}\text { Radioactive waste } \\
\text { Burial yolume (i) } \\
\text { (cu } f(t)\end{array}$ & $\begin{array}{l}\text { Cost for Rewoval, } \\
\text { Pkg, ship, Bury } \\
\text { (s) }(i, j, k)\end{array}$ \\
\hline 1. Reactor Vessel & $1,587,600$ & 2,160 & 69 & 2 & 35.8 & 13,498 & $14,900,008$ \\
\hline 2. Internals & 767,670 & $6,550,150$ & 78 & 2 & 90.5 & 13,900 & Included above \\
\hline $\begin{array}{l}\text { 3. Recirculation Pumps } \\
\text { and Piping }\end{array}$ & 289,786 & & 29 & 2 & 162.7 & 7,338 & 588,300 \\
\hline $\begin{array}{l}\text { 4. Reactor Building } \\
\text { NSSS Components }\end{array}$ & 386,340 & & 26 & 2 & 315.6 & 4.158 & 414,300 \\
\hline 5. Turbine & $3,666,400$ & & 106 & 2 & 7.9 & 59,908 & $2,558,000$ \\
\hline TOTAL & $6,697,890$ & $6,552,310$ & 386 & 2 & 612.5 & 88,878 & $28,460,600$ \\
\hline
\end{tabular}

(a) Weight and activity level information taken from Tables $6.4-3$ of NUREG/CR-g138

(b) Dimensions and weights are approximate and taken from NUREG/CR-gl39, whose source was the Txofan ESAR

(c) occupational exposure based upon dose rates provided in Table G.3-4 of NUREG/CR-6130

(d) Volume includes disposable containers

(e) Costs are presented in 2984 dollars and include labor, materlals, special tooling, burial fees and special train costs.

(f) Information extracted from Tables I.3-3 and I.3-4 of NUREG/CR-8672

(g) Dimensions and weights are approximate and taken from NUREG/CR-9672

(h) Occupational exposure based upon Table I.4-1 of NUREG/CR-6672

(i) Costs are presented in 1984 dollars and Include labor, materials, special tooling and burial fees

(j) Costs assume a local barging facility is available within lo miles from station; barge unloading factlity at burial

(k) Barge transportation costs distributed among components as a function of component welght 
EIGURE $3.14-1$

SEGMENTATION AND CASK LOADING LAYOUT

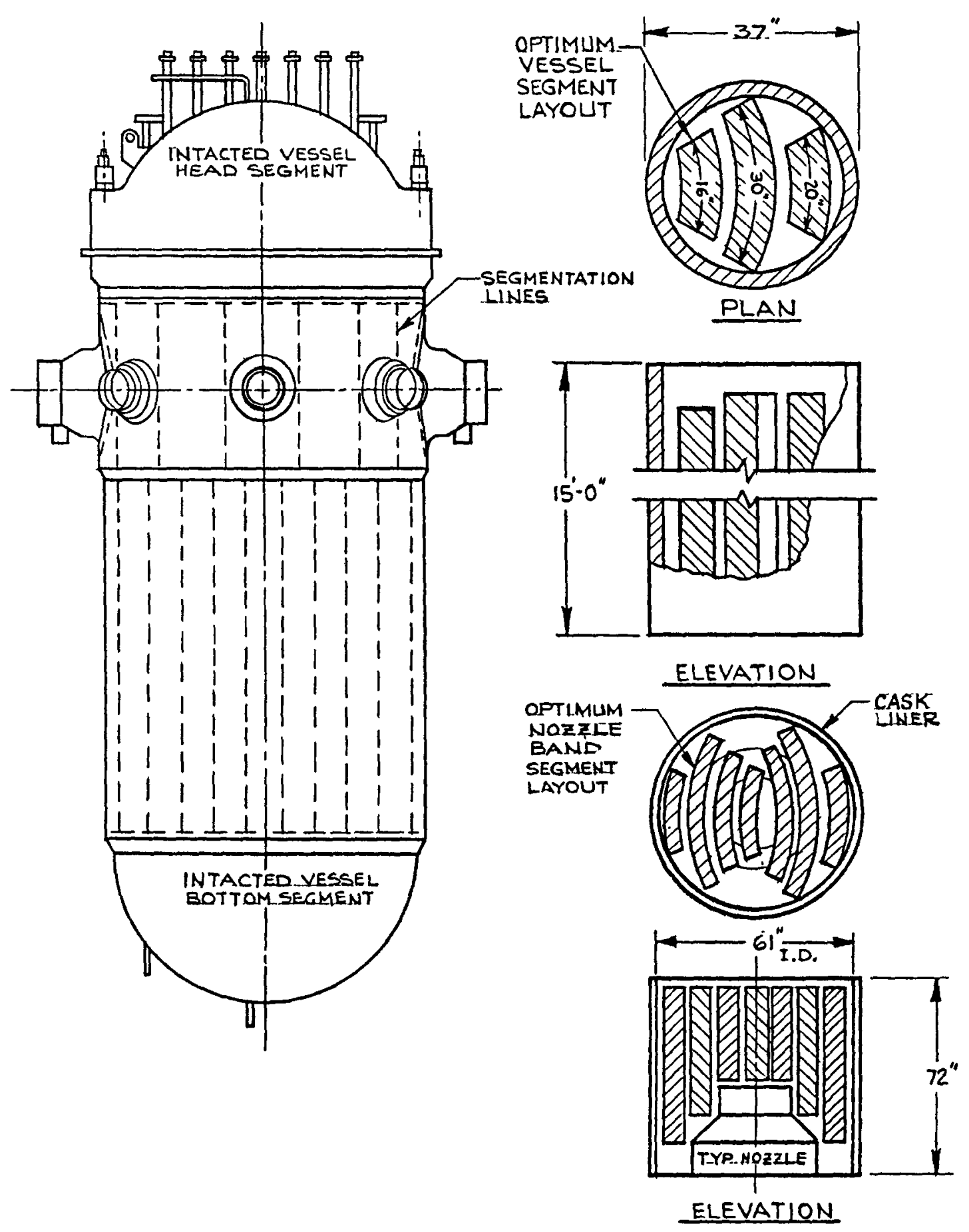


loaded underwater and transferred to the cask for rail shipment. The remaining components would be removed intact, any openings sealed, and loaded onto heavy duty railcars for transport or burial.

The dismantling activities required to ship the components by barge were similar to that by rail. The vessel/internals were segmented in the same fashion and transported in similar casks. The difference between the two shipments was the difference in transport cost (rental), distance to burial ( 500 miles for rail and $20 \emptyset \emptyset$ miles for barge), and exposure incurred during transportation. Table 3.14-5a presents the results for barge shipment and reflects those differences.

\section{Reference BWR}

The BWR NSSS components were assumed to be dismantled in a fashion similar to the reference PWR. The reactor vessel internals would be segmented underwater and loaded into shipping containers. All internals would be shipped in shielded shipping casks similar to General Electric's IF-3øø. The BWR internals were heavier and more activated than the PWR case and, as such, required 68 IF-30ఐ shipping containers for proper disposal. The remainder of the BWR nonactivated internals were shipped in strong-tight containers meeting DOT and NRC specifications.

The pressure vessel was segmented in air and packaged in 69 containers. Vessel head and bottom were shipped intact with openings sealed. The nozzle band was segmented and loaded into 41 CNS 8-120 shipping casks. The activated regions of the vessel were shipped in 26 IF-3øø shipping casks.

The remaining components of the NSSS were shipped either fully intact or in a "minimum number of segments" configuration. The segmentation pattern used for each component was selected as a function of the transportation Iimitations.

The results of the analysis of the BWR facilitation case for rail and barge shipment are presented in Tables 3.14 $-4 \mathrm{~b}$ and 3.14-5b. These tables present the exposures, wastes and costs associated with each NSSS component.

\subsubsection{Conclusions}

The facilitation case results indicated significant reductions would be achieved in exposures and wastes. Table 3.14-6 presents the results of the comparison 
TABLE $3.14-5 a$

\section{BARGE SHIPMENT OF NSSS COMPONENTS: PWR (a)}

\begin{tabular}{|c|c|c|c|c|c|c|c|c|}
\hline & Component & $\underset{(1 b)}{\text { Weight }}$ (b) & $\begin{array}{l}\text { Estimated } \\
\text { Radioactivity } \\
\text { (Ci) }\end{array}$ & $\begin{array}{l}\text { No. of } \\
\text { Con- } \\
\text { tainers }\end{array}$ & $\begin{array}{l}\text { Containers } \\
\text { per } \\
\text { shipment }\end{array}$ & $\begin{array}{l}\text { Occupational } \\
\text { Exposure (c) } \\
\text { (Man-Rem) }\end{array}$ & $\begin{array}{l}\text { Radioactive Waste } \\
\text { Burial Volume (d) } \\
\text { (cu } f t \text { ) }\end{array}$ & $\begin{array}{l}\text { Cost for Removal, } \\
\text { Pkg, ship, Bury } \\
(\$)(e, f, g)\end{array}$ \\
\hline & $\begin{array}{l}\text { RPV (Head, wall, } \\
\text { Bottom) }\end{array}$ & 875,500 & $<19,190$ & 93 & $14 / 4$ & 50.8 & 7,055 & $7,394,460$ \\
\hline 2. & $\begin{array}{l}\text { Vessel Internais: } \\
\text { (Core support Plates/ } \\
\text { Barrel/shroud, Thermal } \\
\text { shield, etc.) }\end{array}$ & 421,190 & $<4,821,526$ & 512 & $32 / 4$ & 65.5 & 3,680 & Included above \\
\hline 3. & Steam Generators (4) & $.752,000$ & & 4 & $4 / 4$ & 49.3 & 21,362 & $5,484,580$ \\
\hline 4. & Pressurizer & 195,080 & & 1 & $1 / 1$ & 24.1 & 2,378 & 261,500 \\
\hline 5. & Reactor Coolant Puraps & 752,000 & & 4 & $1 / 1$ & 23.9 & 4,280 & 874,980 \\
\hline 6. & Reactor Coolant Piping & 222,000 & & 12 & $12 / 1$ & Included above & $1,92 \pi$ & 183,580 \\
\hline & TOTAL & $, 217,609$ & $\langle 4,841,71 \%$ & 1,867 & $67 / 4$ & 212.7 & 15,625 & $14,108,800$ \\
\hline
\end{tabular}

TABLE $3.14-5 \mathrm{~b}$

BARGE SHIPMENT OF NSSS COMPONENTS: BWR (h)

\begin{tabular}{|c|c|c|c|c|c|c|c|}
\hline Component & Weight (i) & $\begin{array}{l}\text { Eutinated } \\
\text { Radioactivity } \\
\text { (Ci) }\end{array}$ & $\begin{array}{l}\text { No. of } \\
\text { Con- } \\
\text { tainers }\end{array}$ & $\begin{array}{l}\text { Containers } \\
\text { per } \\
\text { shipment }\end{array}$ & $\begin{array}{l}\text { Occupational } \\
\text { Exposure (j) } \\
\text { (Man-Rem) }\end{array}$ & $\begin{array}{l}\text { Radloactive waste } \\
\text { Burial Volume (d) } \\
\text { (cu } \mathrm{ft} \text { ) }\end{array}$ & $\begin{array}{l}\text { Cost for Removal, } \\
\text { Pkg, Ship, Buxy } \\
(\$)(e, f, g)\end{array}$ \\
\hline 1. Reactor Vessel & $1,587,698$ & 2,160 & 69 & 2 & 35.8 & 13,498 & $13,481,308$ \\
\hline 2. Inteznals & 767,678 & $6,550,150$ & 78 & 2 & 90.5 & 13,900 & Included above \\
\hline $\begin{array}{l}\text { 3. Recirculation Pumps } \\
\text { and piping }\end{array}$ & 289,780 & & 29 & 2 & 162.7 & 7,338 & 565,486 \\
\hline $\begin{array}{l}\text { 4. Reactor Building } \\
\text { NSSS Components }\end{array}$ & 386,340 & & 26 & 2 & 315.0 & 4,150 & 449,400 \\
\hline 5. Turbine & $3,666,490$ & & 166 & 2 & 8.5 & 50,000 & $3,412,490$ \\
\hline TOTAL & $6,697,890$ & $6,552,310$ & 6,196 & $\mathbf{2}$ & 615.7 & 88,870 & $17,908,506$ \\
\hline
\end{tabular}

(a) Weight and activity information extracted from Tables G.4-3 of NUREG/CR-0130

(b) Dimensions and weights are approximate and taken from NUREG/CR-G139, whose source was the Irojan 7 SAR

(d) Volume includes disposable containers

(e) Costs are presented in 1984 dollars and include labor, materials, special tooling and burial fees

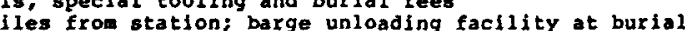

(g) Barge transportation costs distributed among components as a function of component welght

(h) Weight and activity level information extracted from Tables I.3-3 and I.3-4 of NUREG/CR-8672

(i) Dimonsions and weights are approximate and taken from NOREG/CR-8672 
TABLE $3 \cdot 14-6$

\section{ANALYSIS: RAIL/BARGE SHIPMENT OF NSSSS COMPONENTS}

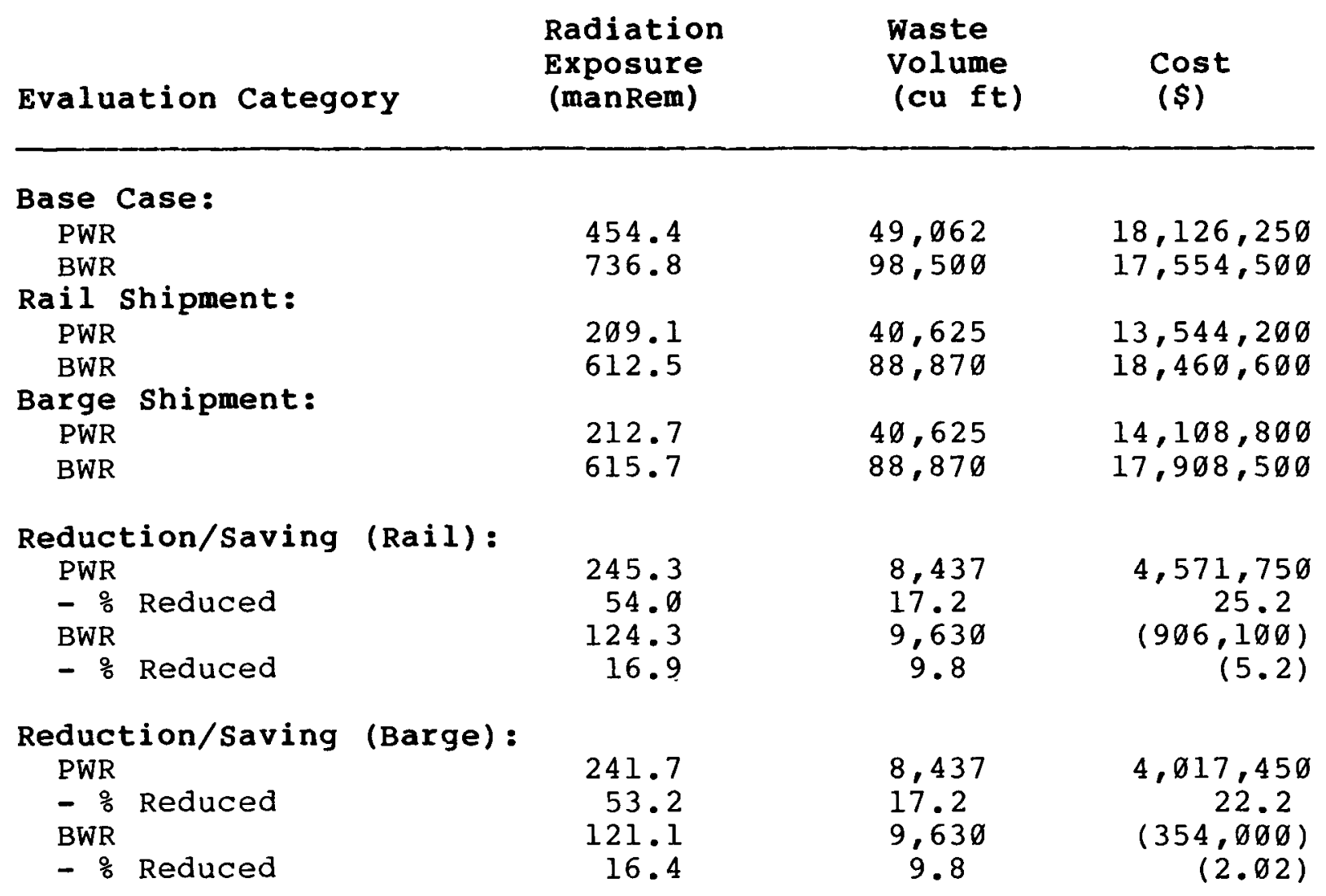

between base and facilitation cases. Rail shipment of PWR components achieved the greatest reduction in both exposure (54.ø9\%) and burial volume (17.2\%).

This technique also indicated a cost savings of appproximately $25.2 \%$ of the original NSSS dismantling costs. Barge shipment of PWR components also achieved savings in all three evaluation categories. However, these savings were slightly less than rail shipment because of the higher exposure and barge rental fees incurred during that shipment scenario.

Rail or barge shipment of BWR components also resulted in appreciable exposure and waste savings. However, additional costs would be incurred in using this option because BWRs have more waste requiring burial $(88,870 \mathrm{cu}$ ft for BWR vs 40,625 for PWR). The transportation costs for shipping this waste excluded the savings resulting from the packaging and shipping of fewer containers. 
3.15 ROBOTICS/AUTOMATED ACTIVITIES

3.15.1 Description

This technique was identified to assess the benefits of implementing the automation of various activities through the application of robotics. Currently, many activities are carried out in radioactively contaminated environments and are performed completely manually, with personnel wearing anticontamination clothing and respirators. These conditions not only decrease productivity but also increase exposure by effectively lengthening the residence time in the radioactive field. It is possible to significantly decrease exposure and increase productivity by automating all or a portion of the task.

\subsubsection{Objective}

The objective of this cost benefit analysis is to determine the net reduction in exposure and increase in productivity that could be expected with activity automation. These cost benefits will be weighed against the capital costs required to automate the task.

\subsubsection{Approach and methodology}

The analysis evaluates the impact of automating decontamination activities such as surface scarifying using a drill and spall technique. This activity was recently automated for robotic scabbler application as part of the Three Mile Island Unit 2 recovery operations. It is assumed a drill and spall machine can be similarly modified to operate from a track-mounted robot.

Contaminated concrete surfaces in PWRs and BWRs can be decontaminated using a drill and spall robot to replace manual drill and spall techniques assumed in the reference studies for PWRs and BWRs, respectively. The robot will essentially eliminate all personnel exposure for this activity because operating personnel can remain in a remote shielded area.

3.15.4 Cost Benefit Analysis

3.15.4.1 Assumptions

1 The decontamination activity is carried out in radiation zones as described in Table G.3-1 of the PWR study, and in Table I.4-1 of the BWR study (Refs. 3-1 and 3-2).

2 This analysis only addresses the scarification of the surfaces, first with a manual drill and spall 
crew and then by an automated drill and spall robot.

3 The manual drill and spall machine removes $50 \mathrm{~mm}$ of concrete surface per pass; only one pass is required to decontaminate the surface.

4 The capital cost for four automated, track-mounted robotic drill and spall carriers capable of being operated without human attention is about $\$ 10 \emptyset, \emptyset \emptyset \emptyset$ (Ref. 3-27) for one robot, or approximately $\$ 2 \emptyset \emptyset, \emptyset \emptyset \emptyset$ for four units. The cost for four drill and spall machines from PNL is $\$ 24, \emptyset \emptyset \emptyset$ (Ref. 3-28). The total cost is estimated at $\$ 224, \emptyset 0 \emptyset$ for four units.

5 Costs from the reference studies in 1978 dollars are adjusted to 1984 dollars by a factor of 1.6 , based on R. S. Means (Ref. 3-4).

\subsubsection{Base Case}

The base case evaluated is the manual drill and spall of contaminated concrete surfaces as reported in the PWR and BWR reference studies. For the PWR, the contaminated concrete surfaces will include $4510 \mathrm{sq} f t$ from the reactor building (Table $6.1-1$ of the PWR study) and the concrete surfaces behind the fuel pool liner in the fuel building. Table G.3-1 of of the PWR study reports the exposures for manual drill and spall. Table G.2-3 shows the labor costs for removal of the spent fuel pool cleanup system, liners and contaminated concrete. One-half the labor cost in 1984 dollars $(\$ 25,16 \varnothing \times 1.536)$ will be assumed for the concrete removal activity. The drill and spall manual machines are $\$ 89,1 \emptyset \emptyset$ for four units $(\$ 58, \emptyset 0 \emptyset \times 1.536)$, in 1984 dollars, as derived from the more detailed Table I.3-9 of the BWR study. This base case is shown in Table $3.15-1$.

TABLE $3 \cdot 15-1$

BASE CASE DRILL AND SPALL EVALUATION

$\begin{array}{cccc}\text { Area }(f t 2) & \begin{array}{c}\text { Exposure } \\ \text { (manRem) }\end{array} & \text { Labor } & \text { Equipment } \\ \text { Cost }(\$) & \text { Cost (\$) }\end{array}$

PWR

$\begin{array}{llll}4,510(+) & 13.55 & 38,645 & 89,100\end{array}$

BWR

$96,876 \quad 45.64 \quad 238,664 \quad 89,10 \emptyset$


For the BWR, contaminated concrete surfaces include the reactor building, turbine-generator building and radwaste building. The total area to be scarified in 96,876 sq ft from Table I.1-2 of the BWR study. The BWR exposures are shown in Table I.3-7; the BWR base case is also shown in Table 3.15-1 herein.

3.15.4.3 Facilitation Case

The facilitation case evaluated is a robot drill and spall machine to perform the concrete scarification. The same crew is assumed to operate the robot for the same duration as the manual crew. The robot is not expected to work at a faster rate nor be any easier to place in position than the manual drill and spall machine. The rate of removal is also assumed to be the same. All maintenance and repair of the robot is assumed performed in a low dose remote area. The analysis comparison for the base and facilitation cases is shown in Table 3.15-2.

TABLE $3.15-2$

ANALYSIS: ROBOTS

Evaluation Category
Base Case
Facilitation Case

\section{Net Reduction \\ Percent Reduction}

\section{PWR}

Radiation Exposure, man Rem

$$
13.55
$$

$\emptyset$

13.55

100

Cost, \$

127,745

224,000

$(96,255)$

$(75.3)$

BWR

Radiation Exposure, man Rem 45.64 $\emptyset$ 45.64 100

Cost, s

327,764

$224, \varnothing \emptyset \emptyset$

103,764

31.7 


\subsection{5 .5 ' Conclusions}

The cost benefit analyses yielded significant reduction in exposure but no reduction in wastes. The costs for robots are still quite high, but as this technology matures along with microcomputer advances, costs are likely to be reduced. Further development will undoubtedly lead to multipurpose robots for additional cost reduction. 
3-1 Smith, R.I., et al., "Technology, safety and costs of Decommissioning a Reference Pressurized Water Reactor Power station", PNL, NUREG/CR-Ø13ø, 1978.

3-2 Oak, D.H., et al., "Technology, Safety and Costs of Decommissioning a Reference Boiling water Reactor Power station", PNL, NUREG/CR-ø672, $198 \emptyset$.

3-3 Code of Federal Regulations, Title 49, Parts 171-178, "Requirements for the Transportation of Radioactive Material."

3-4 "Building Construction Cost Data 1984," 42nd Annual Edition, Robert Snow Means Company, Inc., 1984 .

3-5 Code of Federal Regulations, Title 10, Part 61, "Licensing Requirements for Land Disposal of Radioactive Waste."

3-6 Product Information Bulletin, CGR Compacting, Inc.

3-7 Chem-Nuclear Systems, Inc., "Barnwell Low-Level Radioactive Waste Disposal Facility Rate Schedule," 1984.

3-8 Tri-state Motor Transit Mileage commodity Rates: Docket No. MC-1ø9397, September 5, 1983.

3-9 "An Engineering Evaluation of Nuclear Power Reactor Decommissioning Alternatives," Atomic Industrial Forum, Inc., National Environmental Studies Project, AIE/NESP-øø9, November, 1976.

3-10 Chem-Nuclear Systems, Inc., cask rental rates for the CNS-8-120 (1984).

3-11 Chem-Nuclear Systems, Inc., cask rental rates for the Vandenburg Cask (1984).

3-12 Directory of Certificates of Compliance for Radioactive Materials Packages, US NRC, NUREG/CRø383, December, 1981.

3-13 L.C. Oyen and R.F. Tucker, Jr., "Advanced LowLevel Radwaste Treatment Systems," EPRI-NP-1600, October, $198 \emptyset$.

3-14 "Feasibility and Conceptual Design for a Mobile Incineration System for Combustible LLW," Gilbert Associates, Reading, PA, september, 1982. 


\section{FACILITATION TECHNIQUES DURING OPERATIONS}

4.1

4.2

\section{INTRODUCTION}

This chapter presents techniques that can be implemented during the operations phase of reactor life to reduce exposure and waste volume during decommissioning. Six techniques are identified as applicable to either exposure or waste volume reduction. Three of the techniques are considered to be Good practice and do not require detailed cost benefit analyses. The remaining Cost Benefit techniques required a quantitative evaluation of costs versus exposure or volume reduction.

\section{SUMMARY OF GOOD PRACTICE TECHNIQUES}

These techniques are based on activities or management approaches easily implemented at operating stations and may already be standard operating procedure. Many of the operations techniques considered in the early evaluations for this report are already being applied at operating plants and therefore were not considered new facilitation techniques. Such practices include cleaning contamination spills to unrestricted levels immediately upon detection, prompt changeout of liquid and air filters, and replacement of damaged porous insulation with metal-covered insulation. Such a health and safety approach serves to keep contamination levels, and therefore exposure rates, low.

The three Good Practice techniques identified herein are suggestive of the types of administrative and preventive maintenance methods available to facilitate decommissioning. These techniques were determined to be Good Practice for the operations phase of reactor life. These techniques will provide some exposure and/or waste volume reduction during plant operations but their primary objective is to reduce exposures and wastes during the ultimate decommissioning process.

Technique
$\begin{aligned} & \text { Comprehensive Data Base } \\ & \text { Segregation of oil Bearing } \\ & \text { Wastes }\end{aligned}$

Maintain storage Pools

\section{Primary objective}

Reduce exposure

Reduce waste volume

Reduce waste volume 
1 Comprehensive Data Base

The availability of a comprehensive data base in planning decommissioning and decontamination activities will produce savings in the exposures incurred by the work force through better planning of the activities. Important constituents of a data base include as-built construction drawings, models if appropriate, construction operating/maintenance records, site-specific scenarios of similar nature, and corresponding cost documentation. Information should be available for rapid access and should be cross-referenced to provide an accurate and complete basis for decommissioning planning. Discussion and recommendations for cost benefit analyses are included in section 4.4 herein.

Segregation of Oil Bearing Wastes

This technique simplifies waste treatment and prevents premature disposal of standard treatment media such as resin exhaustion from the oil coating of beads. oil segregation will simplify solidification procedures and the practice should be continued during decommissioning operations.

Maintain storage Pools

Underwater segmentation activities for decommissioning require good water clarity for directing subsurface activities. With this goal in mind, storage pools should be designed and maintained during the life of the facility with attention to water quality, maintaining liner integrity and keeping pool and liner surfaces as clean as possible. pools should have properly sized recirculation and treatment systems, remote vacuum and skimmer fixtures and be equipped with sufficient lighting for inspections.

4.3 SUMMARY OF COST BENEFIT TECHNIQUES

Techniques for operations activities directly affect the incurred exposures and waste volume generated during decommissioning. They also reduce exposures and wastes during operations and therefore enhance the benefit of application to decommissioning. The major activities during operations include system operation (manually opening/closing valves, changing filters, recharging resin beds, draining tanks, etc.), maintenance and repair, inservice inspection and testing. Reduction of piping and component exposure levels by decontamination, reduction of potential recontamination, and the pretreatment of surfaces to reduce accumulation of 
contamination will reduce operational exposures. These techniques will reduce the exposure rates at the end of reactor life and therefore reduce exposures to decommissioning workers.

In like manner, facilitation techniques installed during operations to reduce waste volumes, and whose capital cost is written off over the reactor operating life, provide significant cost advantages to reducing wastes. Any equipment used in these techniques must be maintained in good repair during the operations phase in order to be effective for ultimate decommissioning. The techniques included for the operations phase of reactor life are as follows:

- - Technique

Repassivation

Incineration

Preoperational Electropolishing
Primary objective

Reduce exposure

Reduce waste volume

Reduce exposure 
A comprehensive data base, as used in this context, is a collection of facts containing information about the plant and its contents. This would include operating histories, repair records, purchase requisition information (e.g., weight, dimensions, materials), installed location, latest radiation levels, etc. Considering the number of components within the plant, this quantity of information requires a computer to be used effectively. The availability of such a data base can be one of the key factors in facilitating decommissioning planning and its implementation.

Since decommissioning operations can occur some $4 \emptyset$ years following the construction phase, the condition and maintenance of the original data will depend on the effort expended in the initial planning and design of the facility to anticipate the decommissioning process. The importance of an active and accurate data base is best illustrated by examining the potential impact as a result of not having such a data base. In the decommissioning of the Ames Laboratory Research Reactor, an unforeseen error of tack welds not reported on asbuilt drawings contributed to a delay of approximately seven months and disassembly required an additional cutting tool to be installed (Ref. 4-1). On the scale of a commercial sized reactor decommissioning, such a delay would be magnified - especially if critical path activities are involved or directly affected.

The establishment of a comprehensive data base is the responsibilty of the utility and the AE/constructor. Keeping the data base active and current becomes an operations activity. The information generated during the design/construction phase with direct applicability to decommissioning operations is delineated in Table 4.4-1. This information becomes more critical if a delayed dismantling option is chosen. With the time period between construction and decommissioning reaching or exceeding $7 \emptyset$ years, all first hand experience is lost.

\subsubsection{Objective}

The purpose of this analysis is to qualitatively evaluate the impacts to occupational exposure, radioactive waste volume buried, and the cost of decommissioning with or without the availability of a comprehensive data base. 
TABLE $4 \cdot 4-1$

DATA REQUIREMENTS FOR DECOMMISSIONING PLANNING

Design/Construction Information

1 Structural details including concrete pour drawings, rebar placement, penetration locations (as built)

2 General arrangement drawings

3 Fabrication specifications of reactor vessel and internals packages identifying assembly/ disassembly procedures, material specs, construction details and arrangements, including vessel support and recirculation system interface details

4 NSSS component as-built drawings, arrangement drawings with supporting structural interfaces

5 Equipment \& system specifications, manufacturers as-built/as-installed associated arrangement drawings and piping layouts

6 Construction aids: photographs, installation/placement records, scale models and mockups
Decommissioning Application
Demolition support: core drilling, blast placement, access considerations

Material flow, traffic control, activity sequencing

Radionuclide activation analyses, disassembly/ segmentation planning, automated cutter/manipulator(s) design and mockup, reactor cavity modification

Removal/disassembly procedures, rigging, transportation and disposal scenarios

Removal/dismantling sequencing/scheduling, system/equipment turnover and/or conversion for decommissioning operations

Decommissioning and dismantling planning support 
At the time of construction, a comprehensive data base of the plant inventory of components and structures should be prepared, as well as drawings, QA records, and as-built design changes. No quantitative comparisons are considered meaningful due to the wide latitude in varying design features in power plants, the different approaches used by utilities and architect/engineering firms for cost control and procurement, and the different means to achieve a data base system. Instead, general discussions for each category are given in Section 4.4 .5 .

4.4.4 Cost Benefit Analysis

(None performed)

4.4.5 Discussions and Conclusions

4.4.5.1 Radiation Exposure

The availability of a comprehensive data base is expected to contribute to a decrease in personnel exposure as a result of the ability to provide increased planning for dismantling activities and the corresponding expected increased performance/efficiency of these activities. A data base will better support worker training, the design and accuracy of mockups/simulations used to optimize the performance of activities incurring exposures, and the engineering of complex removal operations such as steam generator lifts.

4.4.5.2 Waste Volume

As in the case of occupational exposure, the data base can be used (through increased planning) to eliminate the generation of unnecessary waste volume. Reduction occurs in the volume of clean material that is routinely included in contaminated removal activities. This clean volume becomes identified for controlled disposal through homogenization with its contaminated counterpart. An increased data profile would serve to reduce/ eliminate the unnecessary volume as well as optimize removal of contaminated material.

4.4.5.3 Cost

The cost of such a data base will depend upon the extent of program development, the phase of design/construction when the data base is instituted, and the degree of required supplementary material necessary over and above the data developed by the utility, $A / E$ or constructor. 
At a minimum, an effort should be made to obtain, catalog and cross reference all as-built/as-installed information deemed pertinent to the decommissioning process prior to plant startup, with the provision to institute an updating program during operation. 


\subsection{REPASSIVATION \\ 4.5.1 Description}

This technique is intended to reduce occupational exposure and potential costs by reducing the inventory of radionuclides fixed on the interior of tanks, piping, valves, pumps and other process equipment, as well as the surfaces of large structures, such as steel pool linings or other building surfaces. This is accomplished by inhibiting or limiting the rate of surface contamination after decontamination.

Recontamination occurs rapidly after the surface is cleaned, whether decontaminated by chemical or mechanical means. The decontamination process leaves the metal substrate microscopically rough and bare; the roughness increases the surface area available to bond with ions and free radicals present in aqueous solutions. These ions form a tough adherent film layer on top of the metal substrate. If the atoms comprising these ions and radicals are radioactive, this layer becomes the major source of radiation from the component in all items exterior to the reactor vessel and internals.

To prevent the rapid buildup of this layer after decontamination, the cleaned surface(s) of the component can be pretreated prior to being put back into service. This pretreatment smoothes the surface and also forms its own adherent layer on the metal substrate, preventing the formation of a layer containing radioactive products. This process is referred to as repassivation of the surface.

\subsubsection{Objective}

This technique was identified to investigate any potential reduction in occupational radiation exposure, waste volume to be buried and costs of removal by repassivation of surfaces prior to being returned to service during plant operations after they have been decontaminated.

\subsubsection{Approach and Methodology}

To prove beneficial, the repassivation of the surfaces should satisfy performance criteria such as those identified in the NRC's "Planning Guidance for Nuclear Plant Decontamination" (Ref. 4-2). First, the process should satisfy the intended purpose; i.e., it must passivate the surface against rapid recontamination with activated corrosion products after the plant returns to service. Second, any chemicals introduced into the 
reactor coolant systems or other safety related systems must be compatible with the chemistry of the system materials as well as the purification system(s) used during operation. Ideally, the initial decontamination process should passivate the metal after removing the surface layer of corrosion product. Practically, this may never be possible while still meeting all other criteria for materials compatiblity, decontamination factor required, etc. Repassivation of the decontaminated surface will be assumed to occur in a two step process.

The most straightforward method of repassivation is to use pure water at high (operational) temperatures and controlled water chemistry over an extended period. This forms a corrosion layer on the surface from the action of the high temperatures and the dissolved oxygen in the water on the base metal (generally iron/nickel chromates in PWRs, and spinel structures in BWRs (Ref. 4-3)). The water chemistry of the environment significantly affects the composition of the corrosion layer with PWR water chemistry $\mathrm{rich}$ in $\mathrm{H}+$ ions forming a much tougher surface than BWR reactor environments.

There are also other potential methods of repassivation, such as the use of mild chemicals to induce a corrosion layer to form. However, this is limited by the constraints of returning the equipment to an operable status. Any treatment promoting the formation of a film layer with a large percentage of chromium should protect the metal substrate from further attack (Ref. 4-4).

While the chemical treatment method is quicker, the hot water method does not attack the seals and seats of valves. It also does not generate any chemical wastes for disposal. The availability of the artificial coatings and other methods have not progressed beyond the laboratory stage at this time. The methods are well known in the semiconductor electronics industry but are only starting to be examined in detail by the nuclear power industry.

It is anticipated that any internal decontamination of system components would be performed on a systematic basis. Therefore, the equipment used for decontamination can also be used for repassivation of the surface. For the purposes of this analysis, repassivation of a BWR reactor cleanup system will be evaluated using hot water for a cycle time of $3 \emptyset$ days ( $72 \emptyset$ hours).

4.5.4 Cost Benefit Analysis

A cost benefit analysis was performed to investigate the desirability of repassivation of the interior surfaces 
of a BWR reactor cleanup system. First the, cost, occupational radiation exposure and waste volume generated under currently expected conditions were examined; then, for sensitivity comparison, assumed $10 \%$ and $26 \%$ reductions in the contamination levels were examined. Higher or lower values may be possible on a plant-specific basis, but the range of values should indicate the degree of sensitivity.

While system decontaminations may be performed periodically (and therefore repassivations), the analysis will consider only the final decontamination and repassivation, since it is the one that affects the cost, burial volume and occupational exposure to the removal crews. Any other repassivation will not assist in the decommissioning operations (though it will reduce doses to operations personnel during plant operation).

\subsubsection{Assumptions}

1 The reference BWR plant configuration (Ref. 4-5) is assumed.

2 The plant will be decommissioned by prompt dismantlement or other method requiring the complete removal of the reactor cleanup system.

3 Any surface decontamination performed prior to the repassivation operation does not further imbed decontamination into the surface; e.g., sandblasting on metal or high pressure water spray on concrete.

4 The repassivation occurs such that no impact to the critical path, and therefore the program schedule, occurs. Thus, no costs for schedule impact are charged to the repassivation.

5 No allowance for additional equipment, or for additional radwaste processing of the repassivation rinse, is accounted for. Whatever special equipment is required for decontamination will be available for repassivation. The repassivation will produce essentially clean water requiring little if any processing prior to returning to condensate storage.

Repassivation of decontaminated surfaces generally lowers the equilibrium level of contamination compared to system conditions prior to the decontamination and repassivation (Ref. 4-6).

7 Waste disposal fees are those from the 1984 schedule of the Barnwell, SC burial facility oeprated by Chem-Nuclear, Inc. 
8 'Labor rates for crews used are those listed as the national average for skilled workers and helpers; foremen are assumed to have a $\$ 2 / \mathrm{hr}$ additional cost over the skilled worker average (Ref. 4-7).

9 All work performed is assumed to be done by a subcontractor; therefore, a contractor overhead and profit factor of 1.6 is applied to all labor costs.

10 All radioactive waste is assumed shipped to a burial ground at $5 \emptyset \emptyset$ miles distance one way.

4.5.4.2 Base Case

A typical BWR reactor cleanup system contains the following equipment:

- 250ø linear ft small bore pipe

- 38øø linear ft large bore pipe

- 83 small bore valves

- 1 pump in the $<3 \theta \emptyset$ pound range

- 5 pumps in the $30 \emptyset-1,00 \emptyset$ pound range

- 2 pumps in the $1, \emptyset \emptyset \emptyset$ - $10, \emptyset \emptyset \emptyset$ pound range

- 5 heat exchangers

- 16 tanks, filters or ion exchanges (5øø gallon capacity)

- Other items such as control cabinets, wiring, etc. not germane to the issue at hand (nonprocess equipment)

The cost for removal (including packaging, shipment by truck and controlled burial) is $\$ 767, \emptyset \emptyset \emptyset$. The burial volume is $9862 \mathrm{cu} f t$. Total manhours of labor required is 15,800 . Of this total, approximately 8,280 manhours are spent in the radiation fields of the cleanup system components, with a resultant occupational radiation exposure to the labor force of 150 manRem after a decontamination flush concurrent with the reactor recirculation system decontamination.

4.5.4.3 Facilitation Case

The cost for ultimate removal is the same as for the base case, or $\$ 767,000$. Additional labor for monitoring the repassivation of the cleanup system during the reactor recirculation system passivation would cost $\$ 22,600$. The burial volume at the time of decommissioning the system is the same, $(9862 \mathrm{cu} f t)$. The increase in burial volume for processing the last repassivation fluid (water) of 29,300 gallons adds approximately $84 \mathrm{cu} f t$ of additional burial volume. The total manhours of labor required is still 15,900, with a total exposure of 8,280 manhours. Assuming a $10 \%$ reduction in contamination, the resultant 
occupational radiation exposure to the labor force after a decontamination flush at the time of decommissioning is 135 manRem. With a $20 \%$ reduction in contamination, the resultant occupational radiation exposure to the labor force decreases to $12 \emptyset$ manRem.

4.5.5 Conclusions

Repassivation in the scenario described resulted in exposure reduction at the time of plant decommissioning with no additional impact to removal costs or waste volume buried. However, there was a small waste volume and cost increase during operation of the plant from the repassivation process. These results are summarized in Table 4.5-1

TABLE $4 \cdot 5-1$

ANALYSIS: REPASSIVATION

\begin{tabular}{|c|c|c|c|c|}
\hline $\begin{array}{l}\text { Evaluation } \\
\text { Category }\end{array}$ & $\begin{array}{l}\text { Base } \\
\text { Case }\end{array}$ & $\begin{array}{c}\text { Facilitation } \\
\text { Case }\end{array}$ & $\begin{array}{c}\text { Net } \\
\text { Reduction }\end{array}$ & $\begin{array}{r}\text { Perce } \\
\text { Reduct }\end{array}$ \\
\hline $\begin{array}{l}\text { Radiation Exposure } \\
\text { (manRem) }\end{array}$ & & & & \\
\hline $\begin{array}{l}\text { with } 10 \% \text { reduction } \\
\text { with } 20 \% \text { reduction }\end{array}$ & $\begin{array}{l}15 \emptyset \\
15 \emptyset\end{array}$ & $\begin{array}{l}135 \\
120\end{array}$ & $\begin{array}{l}15 \\
30\end{array}$ & $\begin{array}{l}10.00 \\
20.00\end{array}$ \\
\hline $\begin{array}{l}\text { Waste volume, cu ft } \\
\text { with } 10 \% \text { or } 20 \%\end{array}$ & 9862 & 9945 & $(84)$ & $(0.85)$ \\
\hline $\begin{array}{l}\text { Costs, } 1984 \\
\text { with } 10 \% \text { or } 20 \%\end{array}$ & 766,900 & 789,500 & $(22,600)$ & $(2.95)$ \\
\hline
\end{tabular}

Several utilities have performed decontamination on various plant systems, including BWR reactor recirculation and reactor cleanup systems (Ref. 4-8). While these efforts did bring about large reductions in area dose rates, recontamination of these systems began upon their return to service. The rate of recontamination is high when compared to the rate of increase prior to the decontamination. This is due to the high reactivity of the cleaned metal compared to the relatively low corrosion rates of metal in service for several years.

It is expected that repassivation generally reduces the equilibrium contamination level of the piping or component surfaces, but the results are highly plantspecific and present data is insufficient to ensure 
success. If decontamination were by electropolishing, the microscopic surface area would have already been smoothed; therefore, contamination levels (and thus radiation levels) should never reach the same levels if they were at equilibrium at time of decontamination. Several utilities in this country and abroad are investigating both decontamination and repassivation methods in the interest of reducing radiation levels during plant operations. Any such program would also reduce the occupational exposures that decommissioning personnel would incur.

Though not related to the analysis, it should be mentioned that any replacement components installed during outages should be surface treated by electropolishing or other passivation method(s), for the same reasons as listed above.

It has been assumed that the repassivation operation does not impact the overall outage, as any impact would incur purchasing replacement power at a rate of $\$ 4 \emptyset, \emptyset \emptyset \emptyset$ to $\$ 75, \varnothing 0 \emptyset$ per hour (depending upon the utility's cost of replacement power) of lost generation time. such a penalty could not be justified. If the original system decontamination were on the critical path, the repassivation would also be on it. In this instance, it would cause a delay of 720 hours until plant startup, for a total cost to the utility of $\$ 29$ million to $\$ 54$ million in replacement power costs.

There may, however, be indirect costs associated with repassivation; namely, the required time of the repassivation operation and its impact on the program schedule in which the decontamination and repassivation occurs. If the time required for repassivation causes delays in returning the system to operation (i.e., there is little slack time in the schedule for decontamination of the system), additional costs may be incurred, such as temporary holdup tankage, or mobile facilities to perform the functions of the system undergoing decontamination/ repassivation. In the extreme case, performing repassivation could delay restart of the plant and incur replacement power costs.

The above costs incurred during plant operation due to the repassivation must be balanced against a possible reduction in the number of system decontaminations required throughout the plant lifetime, as well as the reduction in exposure to operations personnel throughout plant lifetime. 
4.6 INCINERATION

4.6.1 Description

This technique of high temperature incineration of LSA radioactive waste is considered to be a viable means of reducing the waste volume to be sent to controlled burial facilities.

4.6.2 objective

The objective of this cost benefit analysis is to determine the net reduction in radioactive waste volume generated during reactor operations. The analysis included the occupational exposure and cost for incineration. If incineration can be shown to be cost effective for reactor operations, the cost effectiveness of incineration for decommissioning is enhanced.

4.6.3 Approach and Methodology

The analysis included estimation of typical volumes of dry active waste (DAW) generated during PWR and BWR plant operations. These estimates were used in the analysis for the base case for direct burial, and for the facilitation case for incineration. The occupational exposure, waste volume and cost to dispose of these wastes were estimated for each case. The analysis was prepared in the same manner as for the evaluation of incineration during decommissioning (Section 3.9).

4.6.4 Cost Benefit Analysis

4.6.4.1 Assumptions

The assumptions for this cost benefit analysis are the same as for the evaluation of incineration during decommissioning except for the following differences:

1 LSA waste volume quantities are taken from "Cost Benefit Tradeoffs for On-site processing Methods", (Ref. 4-9).

2 Economic life of the mobile incinerator system is assumed to be 10 years.

3 Residual incinerated ash is evaluated for solidification and containment in two different solidification configurations: polymer and high integrity containers. 
The base case considered drumming and burial at a controlled burial ground. The compacted waste generation rate for PWRs was estimated at $76 \emptyset \emptyset$ cu ft per year and for BWRs at 7800 cu ft per year based on Ref. 4-9. The waste volumes are sufficiently similar to use a single value of $780 \emptyset$ cu ft per year. The following table presents a summary of the base case cost benefit analysis.

TABLE $4.6-1$

BASE CASE DISPOSAL OF COMPACTED WASTE

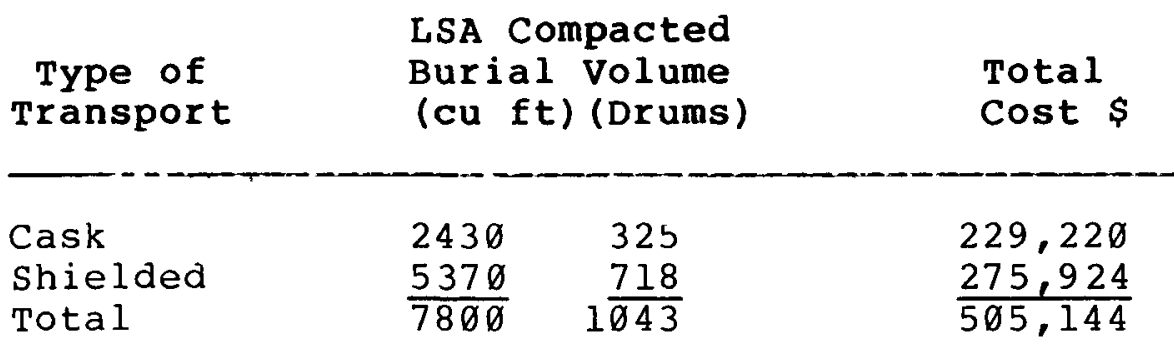

The costs associated with the disposal of DAW included packaging costs (using carbon steel 55-gallon drums), transportation and burial costs as published in chemNuclear systems rate schedules (Refs. 4-9\&4-10). For DAW requiring cask shipment, additional costs included cask rental, cask handling and weight surcharges.

4.6.4.3 Facilitation Case

The facilitation case for operations was developed in the same manner as for the decommissioning case except that the economic life was assumed to be 10 years. Two ash disposition alternatives were considered, including polymer solidification and high integrity container (HIC) disposal. Cement solidification was not included because of its high net volume and overall cost as shown in the decommissioning case (Section 3.9).

Occupational exposures were calculated in the same manner as for the decommissioning case. They are reported herein as the decrease (increase) per year over the base case exposures from compaction. The results of the facilitation case are shown in Table 4.6-2.

4.6.5 Conclusions

The analysis showed substantial volume reduction. Although the exposure percentage increase is large, the exposure is only a small percentage in overall exposure 
TABLE $4.6-2$

FACILITATION CASE INCINERATION OF WASTE FROM OPERATIONS

\begin{tabular}{llcc}
$\begin{array}{l}\text { Burial } \\
\text { Volume } \\
(\text { cu ft) }\end{array}$ & $\begin{array}{l}\text { Net Volume } \\
\text { Reduction } \\
\text { Ratio }\end{array}$ & $\begin{array}{l}\text { Total } \\
\text { Cost } \\
(\$)\end{array}$ & $\begin{array}{c}\text { Exposure } \\
\text { Decrease } \\
\text { (manRem/Yr) }\end{array}$ \\
\hline 561 & 14 Polymer & 351,294 & $(3.48)$ \\
352 & 22 HIC & 348,268 & $(2.98)$
\end{tabular}

from plant operations. The disposal costs are also substantially reduced by incineration of operating plant wastes. The summary of results of the cost benefit analysis is shown in Table 4.6-3

TABLE $4 \cdot 6-3$

INCINERATION OF DAW FROM OPERATIONS

\begin{tabular}{|c|c|c|c|c|}
\hline $\begin{array}{l}\text { Evaluation } \\
\text { Category }\end{array}$ & $\begin{array}{l}\text { Base } \\
\text { Case }\end{array}$ & $\begin{array}{c}\text { Facilitation } \\
\text { Case }\end{array}$ & $\begin{array}{c}\text { Net } \\
\text { Reduction }\end{array}$ & $\begin{array}{l}\text { Percent } \\
\text { Reduction }\end{array}$ \\
\hline $\begin{array}{l}\text { Radiation } \\
\text { Exposure) } \\
\text { (manRem) }\end{array}$ & 1.84 & $\begin{array}{l}3.48 \text { Polymer } \\
2.98 \text { HIC }\end{array}$ & $\begin{array}{l}(1.64) \\
(1.14)\end{array}$ & $\begin{array}{l}(89.1) \\
(62.0)\end{array}$ \\
\hline $\begin{array}{l}\text { Waste } \\
\text { volume, } \\
\left(\begin{array}{ll}\text { cu ft) }\end{array}\right.\end{array}$ & 7800 & $\begin{array}{ll}561 & \text { Polymer } \\
352 & \text { HIC }\end{array}$ & $\begin{array}{l}7239 \\
7448\end{array}$ & $\begin{array}{l}92.8 \\
95.5\end{array}$ \\
\hline Costs, $\$$ & 505,144 & $\begin{array}{l}351,294 \\
348,268\end{array}$ & $\begin{array}{l}153,850 \\
156,876\end{array}$ & $\begin{array}{l}30.5 \\
31.1\end{array}$ \\
\hline
\end{tabular}

These results show that incineration of operations waste is cost effective for volume reduction. The overall cost for disposal of DAW decreases from approximately $\$ 65 / \mathrm{cu} f t$ for the base case to approximately $\$ 45 / \mathrm{cu} \mathrm{ft}$ for the facilitation case. If the incinerator is also available for decommissioning, the capital cost will already have been fully recovered and the overall cost effectiveness for incinerating decommissioning wastes will improve. Taking the BWR decommissioning case as an example, the only costs will be for incinerator operations, packaging, shipping and burial of ash. Table 4.6-4 summarizes the cost reduction for incineration of decommissioning wastes with an existing on-site mobile 
type 'incinerator. The exposure and waste volume reduction are the same as shown in Table 3.9-2b.

TABLE $4.6-4$

INCINERATION OF WASTES WITH AN EXISTING INCINERATOR

\begin{tabular}{|c|c|c|c|c|}
\hline $\begin{array}{l}\text { Evaluation } \\
\text { Category }\end{array}$ & $\begin{array}{l}\text { Base } \\
\text { Case }\end{array}$ & $\begin{array}{c}\text { Facilitation } \\
\text { Case }\end{array}$ & $\begin{array}{c}\text { Net } \\
\text { Reduction }\end{array}$ & $\begin{array}{l}\text { Percer } \\
\text { Reduct }\end{array}$ \\
\hline Cost, $\$$ & 505,144 & $\begin{array}{ll}198,695 & \text { Polymer } \\
195,669 & \text { HIC }\end{array}$ & $\begin{array}{l}306,449 \\
309,475\end{array}$ & $\begin{array}{l}60 \cdot 7 \\
61 \cdot 3\end{array}$ \\
\hline
\end{tabular}

For this latter case, the overall cost for disposal of DAW decreases from approximately $\$ 65 / \mathrm{cu}$ ft to approximately $\$ 25 / \mathrm{cu} f t$. Therefore, use of a mobile type incinerator for operation wastes, and subsequent decommissioning wastes, is a cost effective facilitation technique. 


\subsubsection{Description}

This technique is intended to reduce occupational exposure by reducing the inventory of radionuclide contamination buildup on the interior of piping, valves and pumps. The internal geometry of most other components is too complex to achieve reliable results. Electropolishing the interior surface of each component immediately after fabrication but prior to installation will smooth the surface and reduce the buildup of contamination during plant operation. Figure 4.7-1 shows a schematic of an electropolishing tank for pipe decontamination.

\subsection{2 objective}

The objective of this cost benefit analysis was to evaluate whether the additional fabrication cost to electropolish the interior surfaces of the piping and components in a reactor system will effectively reduce occupational exposure during decommissioning.

\subsubsection{Approach and Methodology}

There is no long term contamination data to predict with accuracy how much reduction might be achieved by electropolishing pipe during fabrication. As reported by J. Blok at the Executive Conference on Decontamination (Ref. 4-6), recent in-plant tests with piping specimens of as-received and electropolished pipe indicate substantial reduction of contamination levels on electropolished pipe. The co-6ø activity contamination on electro-polished pipe was less than half that on as-received pipe ( 7 vs. 18 micro curies per square centimeter) for the same exposure time.

It is uncertain whether the same relationship would continue throughout the operating life of a plant. Equilibrium contamination levels of the two types of surfaces may ultimately show less of a difference. For this cost benefit study it was assumed that the electropolished surface contamination levels (and hence the dose to workers) would be reduced by $10 \%$ to $20 \%$ in comparison with the levels of as-received piping and components.

The cost to electropolish the interior of surfaces included the estimated costs for equipment, chemicals, electricity and labor. The equipment required was assumed to be similar to the system described in PNLSA-6858 (Ref. 4-12). Operating costs were estimated from PNL SA-6858 using 1984 costs for chemicals and 
FIGURE $4.7-1$

ELECTROPOLISHING THE INTERIOR OF LONG PIPE

$\stackrel{t}{t}$
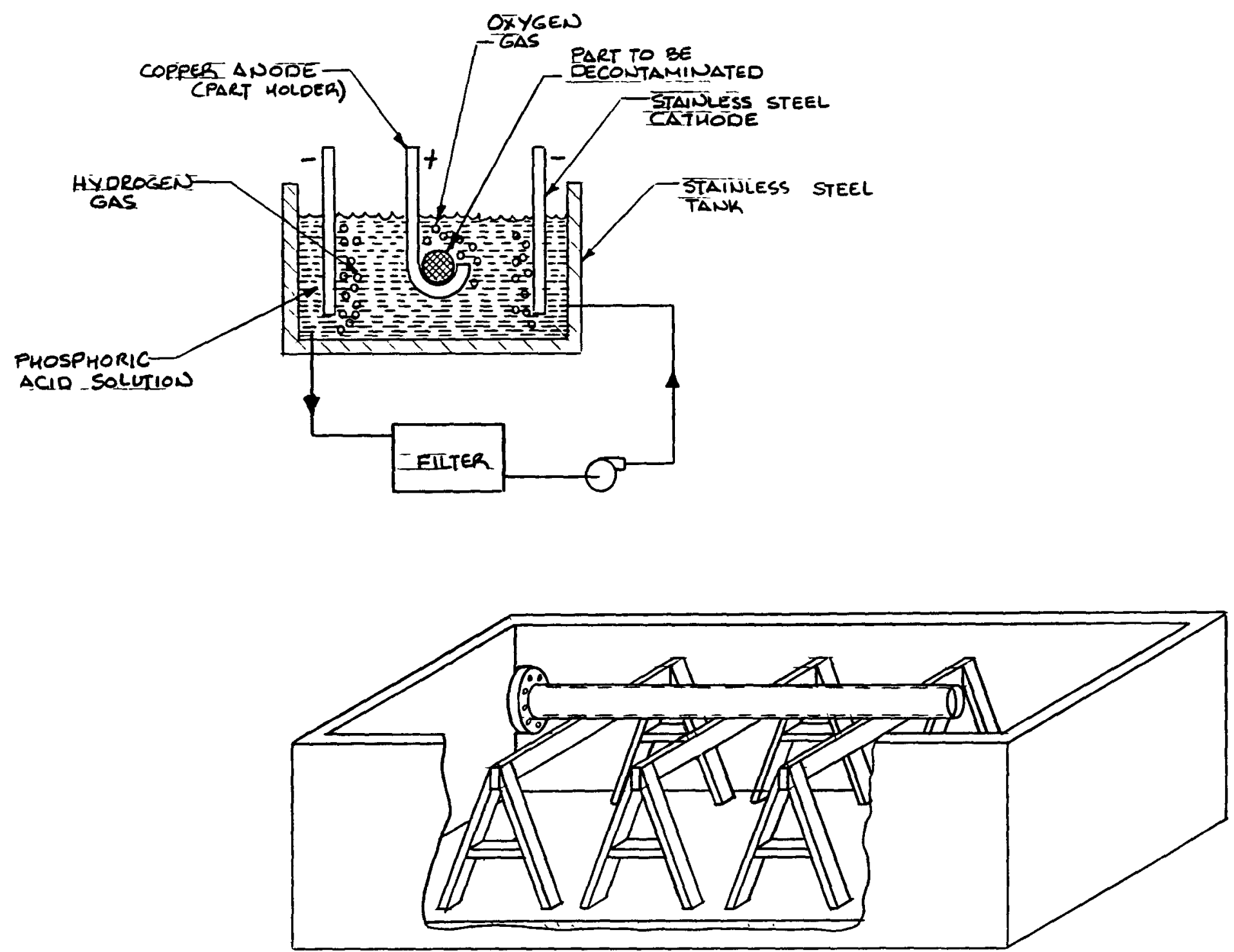
electricity. A four man crew was assumed, consisting of a foreman, an electropolishing technician and two laborers. Their duties consisted of loading components in the electropolishing tank, attaching electrodes, adjusting chemical concentrations, rinsing and unloading the components. The system was assumed located at the receiving warehouse at the nuclear station so that no additional transportation or handing would be required.

The system selected for this analysis was a BWR reactor water cleanup system. Only piping, valves and pumps were included in the analysis. Valves and pumps were considered to have the same interior surface area as a pipe of the same valve or pump length.

4.7.4 Cost Benefit Analysis

4.7.4.1 Assumptions

1 The reference BWR described in NUREG/CR-ø672 (Ref. 4-5) configuration is used for piping, valve and pump inventory.

2 The plant will be decommissioned by prompt dismantlement; this approach requires complete removal of the reactor water cleanup system.

3 The reactor water cleanup system will be chemically decontaminated prior to disassembly and removal.

4 Waste disposal fees are those from the 1984 schedule for the Barnwell, SC burial facility operated by Chem-Nuclear systems, Inc.

5 Labor rates for crews used are those 1 isted as national average for skilled workers and helpers; foremen are assumed to have a $\$ 2 . \emptyset \emptyset /$ hour additional cost over the skilled worker average, as shown in $\mathrm{R}$. S. Means (Ref. 4-7).

6 All cleanup system removal is assumed to be done by a subcontractor and therefore an overhead and profit factor of 1.6 is applied to all labor costs.

7 All radioactive waste is assumed shipped to a burial ground at $5 \emptyset \emptyset$ miles distance one way.

8 There is no effect on the volume of radioactive waste to be buried. 
4.7.4.2 Base Ćase

A typical BWR reactor water cleanup system contains the following piping, valve and pump inventory:

- $25 \emptyset \emptyset$ ft of small bore pipe (2" diameter or less)

- $380 \emptyset$ ft of large bore pipe

- 83 small bore valves

- 1 pump less than 300 lbs

- 5 pumps $3 \emptyset \emptyset-10 \emptyset \emptyset 1 b s$

- 2 pumps $10 \emptyset \emptyset-10, \emptyset \emptyset \emptyset 1$ bs

The total cost for decontamination, removal, packaging, shipping and burial is $\$ 635,943$. The occupational exposure to remove these components is 83.4 manRem.

4.7.4.3 Facilitation Case

The cost to electropolish these components includes the fixed equipment cost for tanks and equipment plus the operating costs for labor, chemicals and electricity. These four cost elements were developed on a cost per interior surface area basis. At a current density of $1500 \mathrm{~A} / \mathrm{m} 2(140 \mathrm{~A} / \mathrm{sq} \mathrm{ft})$ at 10 volts and a soak time of 45 minutes per square foot (including setup), the average electopolishing operating cost is $\$ 18 / \mathrm{sq} \mathrm{ft}$.

The total interior surface area for the piping, valve and pump inventory is as follows:

Small bore pipe (1" nominal ID)

Large bore pipe (6" nominal ID)

Small valves ( 1 " nominal ID)

1 Pump less than 300 lbs

5 Pumps $300-1000$ lbs

2 Pumps $1 \emptyset \emptyset \emptyset-1 \emptyset, \emptyset \emptyset \emptyset$ lbs

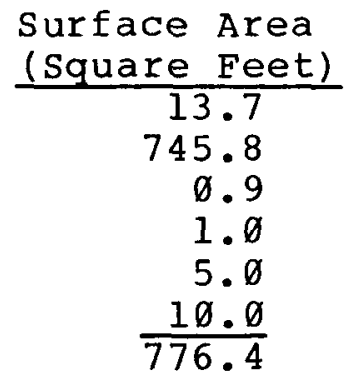

Surface Area

13.7

45.8

1.0

5.0

$\frac{10.0}{776.4}$

The total cost to electropolish these components is therefore $776.4 \mathrm{sq}$ ft $x \$ 18 / \mathrm{sq} \mathrm{ft}=\$ 13,975$. The cost for decommissioning this system, including decontamination, removal, packaging, shipping and burial, is the same as for the base case.

\subsubsection{Conclusions}

The overall effectiveness of preoperational electropolishing is shown in terms of the assumed reduction in occupational exposure. Table 4.7-1 shows the base case and facilitation case summary for an assumed $10 \%$ and $20 \%$ reduction in exposure. These results indicate the overall effectiveness of preoperational electropolishing is beneficial in reducing exposures without incurring a large expense. 
TABLE 4 .7-1

ANALYSIS: PREOPERATIONAL ELECTROPOLISHING

\begin{tabular}{|c|c|c|c|c|}
\hline Evaluation Category & $\begin{array}{l}\text { Base } \\
\text { Case }\end{array}$ & $\begin{array}{l}\text { Facilita- } \\
\text { tion Case }\end{array}$ & $\begin{array}{c}\text { Net } \\
\text { Reduction }\end{array}$ & $\begin{array}{l}\text { Percent } \\
\text { Reduction }\end{array}$ \\
\hline \multicolumn{5}{|l|}{$\begin{array}{l}\text { Radiation Exposure } \\
\text { (manRem) }\end{array}$} \\
\hline $\begin{array}{l}\text { with } 10 \% \text { reduction } \\
\text { with } 20 \% \text { reduction }\end{array}$ & $\begin{array}{l}83.4 \\
83.4\end{array}$ & $\begin{array}{l}75.1 \\
66.7\end{array}$ & $\begin{array}{r}8.3 \\
16.7\end{array}$ & $\begin{array}{l}10 \\
2 \emptyset\end{array}$ \\
\hline $\begin{array}{l}\text { Costs, (\$) } \\
\text { with } 10 \% \text { or } 20 \%\end{array}$ & 635,943 & 649,918 & 13,975 & $(2.2)$ \\
\hline
\end{tabular}


4.8, REEERENCES

4-1 "Decommissioning of the Ames Laboratory Research Reactor," prepared for the Department of Energy, Ames Laboratory, Iowa state University, January, 1982 .

4-2 L. F. Munson, et al., "Planning Guidance for Nuclear Plant Decontamination," NUREG/CR-2963 or PNL-4585, U.S. Nuclear Regulatory Commission, 1982.

4-3 R. A. Shaw and C. J. Wood, "overview of Chemical Decontamination Technology," Electric Power Research Institute, from the proceedings of the American Nuclear Society Executive Conference, "Decontamination of Power Reactors: The cost, Benefits and Consequences," September 16-19, 1984.

4-4 H. Ishii, et al., "Study on Recontamination of Chemically Decontaminated Stainless Steel Surface," from the proceedings of the American Nuclear Society/Canadian Nuclear Association International Joint Topical Meeting, "Decontamination of Nuclear Facilities," September 19-22, 1982.

4-5 H. D. Oak, et al., "Technology, Safety and Costs of Decommissioning a Reference Boiling water Reactor Power Station," NUREG/CR-ø672, U.S. Nuclear Regulatory Commission, 1980 .

4-6 J. Blok, "Recontamination and Passivation," Radiological and Chemical Technology, Inc., from the proceedings of the American Nuclear society Executive Conference, "Decontamination of Power Reactors: The Cost, Benefits and Consequences," September 16-19, 1984 .

4-7 "Building Construction Cost Data, 1984," 42nd Annual Edition, Robert Snow Means Company, Inc., 1984.

4-8 W.P. Murphy, "Decontamination of Power Reactors: The Cost, Benefits and Consequences," Vermont Yankee Nuclear Power Corporation, from the proceedings of the American Nuclear Society Executive Conference, "Decontamination of Power Reactors: The Cost, Benefits and Consequences," September 16-19, 1984 .

4-9 R.J. Tossetti, "Cost Benefit Tradeoffs for on-site Processing Methods", Second Joint ASME/ANS Nuclear Engineering Conference, Portland, Oregon July 25-28, 1982 . 
4-10 Tri-state Motor Transit Mileage Commodity, Rates: Docket No. MC-1ø9397, September 5, 1983.

4-11 Chem-Nuclear Systems, Inc., "Barnwell Low-Leve1 Radioactive Waste Disposal Facility Rate schedule," January 1,1984 .

4-12 Pacific Northwest Laboratory: "Electropolishing as a Decontamination Process: Progress and Applications," PNL-SA-6858, April 1978 . 


\section{FACILITATION TECHNIQUES DURING DESIGN/CONSTRUCTION}

This chapter presents potential design and construction techniques for facilitation of decommissioning. These techniques were identified for their potential to reduce either radioactive waste volume or worker occupational exposure inherent in the decommissioning process. This section presents techniques for accomplishing at least one of the objectives, as applicable to plant design and construction activities. In most cases they are applicable to any design, redesign, construction or backfit work during plant operating life. Twenty-one techniques are considered to be Good Practice and will not require detailed cost benefit analyses. The remaining cost Benefit techniques will also reduce exposure or wastes, but the benefits should be quantified with respect to costs.

The recommendations presented herein are identified for application during plant design and construction. presentation of these recommendations is intended so that the consequences of plant design/modification and construction/implementation are considered on decommissioning and on the potential of affecting both the plant operating and end of life radiological condition.

5.2 SUMMARY OF GOOD PRACTICE TECHNIQUES

These techniques are based on plant design features or construction methods that can only be incorporated in the original plant design (or major modifications to an existing plant). Some of these techniques must be installed before the plant becomes contaminated. Several of these techniques will also reduce exposures and/or wastes during operations. The Good practice techniques identified in this chapter are listed herein.

$\frac{\text { Technigue }}{\text { Construction Scale Models }}$
Remote Sampling/Measuring
Capability

Sealed Nonporous Insulation

Enclosed Cable Trays
Primary Objective

Reduce exposure

Reduce exposure

Reduce waste volume

Reduce waste volume 
Minimize Cable Trays in Contaminated Areas

Relocated Motor Control Centers

Sufficient waste storage Capacity

Bolted steel Construction

Flanged Construction of Components

Quick Disconnect Components

Shearable Nuts and Bolts

Non-Embedment of Pipes

in Concrete

Removable Roof, Wall panels Reduce exposure Access to and into A1l Tanks

Plant Breathing Air Supply

System

Pre-Installed Manipulator Support

Lifting Lugs on Large Components

Anchor points for Lifts

Tracks for Remote cutting Devices

Preplaced Core Samples

Complete Drainage Capacity
Primary objective

Reduce waste volume

Reduce waste volume

Reduce exposure

Reduce waste volume

Reduce exposure

Reduce exposure

Reduce exposure

Reduce waste volume

Reduce exposure

Reduce exposure

Reduce exposure

Reduce exposure

Reduce exposure

Reduce exposure

Reduce exposure

Reduce exposure

These techniques were determined to be Good practice for the design and construction phase of reactor life. Some will provide exposure and waste reductions only for decommissioning while others will provide benefits for both operations and decommissioning. These techniques are more readily installed prior to plant startup before systems and structures become contaminated. 
The availability of construction models improves planning efficiency, aids in constructing simulations and mockups and improves ALARA planning. Models can be used to plan equipment setup, location of air, power and water utilities, and removal of segmented components. Exposure savings can also be realized during the operational life of the facility by using models as planning aids. They can be used to plan and train for maintenance, repair, modifications and inservice inspections throughout the operating life.

Construction models are usually $1 / 10 \emptyset$ scale of the actual facility and show all structures, systems and components, including large bore (greater than 2-1/2" diameter) piping in a cutaway or transparent model.

Remote Sampling/Measuring Capability

This technique reduces exposure associated with environmental sampling activities by allowing the data to be gathered remotely. The technique involves the installation of remote monitors, shielded access points and automated data collection and dissemination equipment. The equipment must be incorporated into plant design to be cost effective.

3 Sealed Nonporous Insulation

This technique is designed to minimize contaminated insulation by preventing the absorption of the contaminated liquids by the insulation. Insulation is sealed in a nonporous, easily decontaminable waterproof jacket to inhibit moisture absorption and prevent the insulation from becoming a source of exposure. The technique reduces exposure and prevents contamination of a large quantity of material.

\section{$4 \quad$ Enclosed Cable Trays}

This technique prevents the contamination of large quantities of cabling by totally enclosing the trays with solid sheet metal. The technique is made more effective with the installation of fire retardent materials and blanketing of the trays and cables.

\section{Minimize Cable Trays in Contaminated Areas}

This technique minimizes contamination of cable trays by locating trays in clean areas. Branch feeders to specific equipment may then be run in enclosed cable trays or conduit. 
This technique is aimed at reducing the amount of contaminated equipment by locating motor control centers in areas that are not susceptible to contamination. Ideally, this concept should be applied for all equipment; however, this is not practical considering the constraints in operating plant arrangements.

Sufficient waste storage Capacity

This technique is intended to circumvent critical path items. Either during construction or just prior to decommissioning, a waste storage facility could be constructed on-site to provide temporary storage space. This will help avoid two problems: (1) waste can be generated at a rate greater than can be shipped off-site (causing a plant with inadequate storage space to become bottle-necked), thereby slowing down work and, (2) without adequate storage facilities, radioactive wastes may have to be stored in areas that may pose increased exposure hazards.

Bolted steel Construction

This technique is intended to reduce exposure by decreasing disassembly time and reducing radioactive waste by using an easily decontaminable construction material. This technique is also cost effective because decontaminated steel can eventually be sold for scrap. Components and structural items such as walls, floors and shields can be constructed out of steel and bolted together. For example, flat sections of steel plate similar to conventionally used floor gratings could be directly bolted to beams for faster construction and demolition. At the time of decommissioning the bolts would be removed or cut enabling rapid disassembly. The use of steel rather than concrete would facilitate use of surface decontamination and volume reduction techniques such as electropolishing or chemical cleaning. Bolted segments would also be designed to fit into waste containers, thereby reducing void spaces and avoiding the need for segmentation.

\section{Flanged Construction of Components}

This technique is intended to reduce exposure by decreasing the time required to disconnect components and avoiding the use of contamination spreading procedures. Cutting methods such as power hacksaws and circular cutters will generate particulate, and torches will generate particulate and contaminated gases. Bolted connections will minimize this contamination 
potential. Items such as pumps, valves, sections of large bore piping or steam generators should be designed so that they incorporate flanged and bolted connections. Flanged connections would facilitate rapid removal. This technique is limited in application to low pressure systems where leakage of seals is less likely to occur.

10 Quick Disconnect components

This technique is intended to reduce exposure by decreasing the time required to disconnect components. Whenever possible, components could be designed and installed with quick disconnect couplings. This would allow rapid disassembly at the time of decommissioning. Systems should be designed for rapid replacement of these quick disconnects. Adequate leakage collection is necessary to prevent spills.

11 Shearable Nuts and Bolts

This technique is intended to reduce exposure by reducing exposure time and/or allowing remote segmentation. Bolted construction could be made using a specialized nut that has a 1" - 3" long shoulder shaft incorporated into its design. At the time of construction, the bolts and nuts would be tack welded to meet applicable codes. At decommissioning, the threaded portion of the bolt and nut could easily be sheared off with a bolt cutter or remote hydraulic shear. Segmenting a flanged pipe section could be performed in minutes without elaborate setup, thereby significantly reducing personnel exposure.

12 Non-Embedment of Pipes, Ducts and Equipment in Concrete Structures

This technique is intended to reduce the effort and exposure time required to remove various items at the time of decommissioning. Whenever possible, embedment of radioactive pipes, duct and equipment into concrete structures should be avoided.

13 Removable Roof, Wall Panels and Plugs

This technique provides improved access to radioactive components to be removed. This will reduce exposure by eliminating unnecessary segmentation and manuevering time to remove radioactive items. Components can be lifted, removed and shipped intact.

14 Access to and into all Tanks

Access to and into tanks will allow decontamination by water lancing or entry of a decontamination technician. 
Large manholes with access ladders and work platforms outside the manhole will shorten setup time and facilitate tank interior decontamination. This technique should be incorporated into present plant design philosophy.

15 Plant Breathing Air Supply System

A system to supply breathing air to potential airborne work areas in the plant should be installed at the time of plant construction. This will reduce the time needed to set up portable units and support equipment in radiation areas and will reduce exposure time. This will also avoid running long air supply hoses through work areas, thus avoiding safety hazards or the obstruction of decommissioning work.

16 Pre-Installed Manipulator Support

This technique is intended to reduce exposure during segmentation of a vessel. The support structure attached to the plasma arc cutter (or other torch tool) manipulator is designed for use on the external suface of the vessel and is installed before startup of the plant. Exterior circumferentially geared or magnetic track would be pre-installed and aligned to receive the torch cutting head assembly. During decommissioning, circumferential segment rings of the vessel can be lifted out and moved to the fuel or service pool for further segmentation. Therefore, a portion of the work that is normally performed in a high radiation area is done in a low radiation environment, thereby minimizing radiation exposure.

17 Lifting Lugs on Large Components

This technique involves the incorporation of lifting lugs into the design of large components to facilitate rigging for intact removal. By installing the lifting features before plant startup rather than in a radioactive environment, significant radiation exposures can be prevented.

18 Anchor Points for Lifts

This technique involves the preplacement of anchor devices around large components that must be 1 ifted during decommissioning. By incorporating the anchor points into the plant during the construction phase, it will avoid much of the time spent needed for rigging in a radioactive environment. 
19 Tracks for Remote Cutting Devices

This technique involves pre-installing (at the time of construction) cutter guide tracks used to guide segmentation devices on components that will become radioactive. Thus, a portion of the decommissioning setup work is performed in a radiation-free environment, eliminating that portion of worker exposure.

20 Preplaced core Samples

This is an exposure reducing technique. It eliminates the time consuming task of concrete core drilling in high radiation areas needed to obtain samples to determine activated concrete profiles. The core samples are drilled or cast in-place during preoperational stages and then held in-place for the life of the plant. At the time when radiologicial characterization of the concrete is desired, the cores are simply pulled out in minutes rather than the hours or days that it takes by core drilling. Thus, there is a very significant reduction in the time spent in a high radiation area.

21 Complete Drainage Capacity

The capability of complete drainage minimizes exposure to the worker from pockets and dead legs containing contaminated liquids. It also permits complete flushing and drying of the system prior to dismantling. Drain connections should be located on system lowpoints and designed to drain to appropriate collection tanks.

5.3 SUMMARY OF COST BENEFIT TECHNIQUES

The remaining cost Benefit techniques required analyses to evaluate their potential benefit. Power station layouts and the arrangement of systems and components differ appreciably from site to site and with respect to the $A / E$, Nuclear steam supply system (NSSS), the contractor, vendors and utility groups involved. However, there are considerations in the design and arrangement of systems and equipment that affect its radiological characteristics and thereby restrict its options of operation, maintenance and eventual disposition.

Analysis of any one technique will have to be on a case by case basis to determine the actual benefit to a specific facility. However, these techniques address those particular generic decommissioning activities that are expected to incur occupational exposure and radioactive waste volume. The techniques included herein are the following: 
Primary objective

Canal Gate

Reduce exposure

Comprehensive Data Base

Reduce exposure

Containment of Liquids

Reduce exposure

Preplaced Blast Holes

Reduce exposure

Smooth and coat Concrete

Reduce waste volume

Substitution and Purification of Materials

Modular Construction of the Bioshield

Reduce exposure

Reduce exposure 
5.4.1 Description

The refueling pool/canal structure above the reactor vessel is designed so that the area in and around the reactor cavity is completely flooded during refueling and maintenance operations (see Figure 5.4-1 for a typical PWR canal layout). Such a design is not optimal for decommissioning; however, it does force the segmentation of the reactor vessel and internals into a series rather than a parallel operation. This is due to the need for a water covering to shield the dose from the reactor internals throughout the segmentation and cask loading. The water level in the canal must be kept below the level of cutting. Therefore, vessel segmentation cannot begin until all internals segments have been removed because the vessel forms part of the canal water boundary. The installation of a canal gate for decommissioning would permit parallel cutting of vessel and internals. The resulting reduction in segmentation duration would thereby reduce the time the segmentation crew would remain in the radiation field and reduce overall exposure to the crew.

In general, BWR reactors do not have this problem since Mark I and II containment designs are already partitioned for normal operation requirements. Mark III containments might require canal modifications to enable vessel/internals segmentation to proceed in parallel operations but would not require the addition of another wall such as a canal gate to achieve the same results.

5.4 .2 objective

The objective of this analysis is to determine the potential reduction in decommissioning exposure and waste volume by designing a canal gate into the layout of the refueling canal.

\subsubsection{Approach and Methodology}

This analysis will examine the impacts of installing a refueling canal gate at the time of plant construction. The vessel/internals segmentation process with the canal gate installed will be compared to the vessel/internals segmentation process without the use of such a gate.

In most PWR designs the reactor is in the center of the canal with the internals storage stand(s) to either side of the vessel. The fuel transfer mechanisms for moving spent fuel assemblies to the adjacent fuel building are located at one end of the canal. 
FIGURE 5.4-1

REFERENCE PWR REFUELING CANAL

$\stackrel{1}{1}$

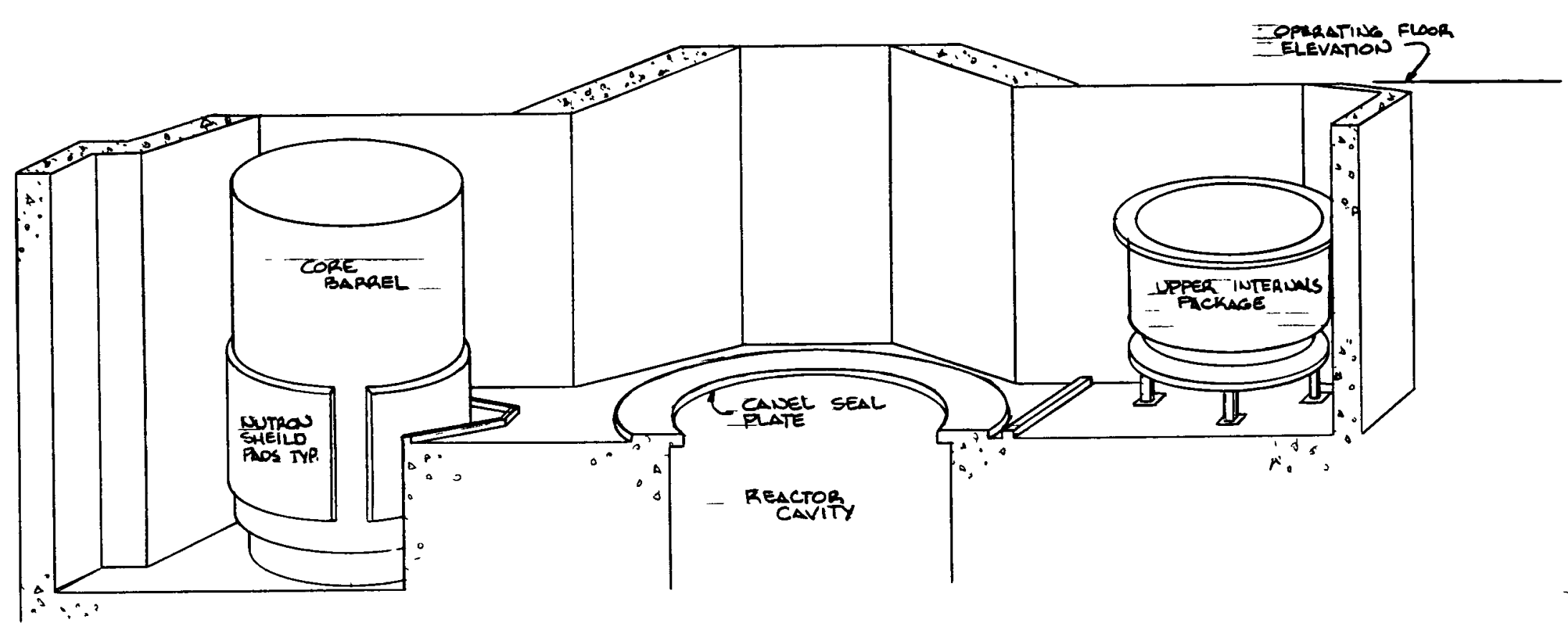


The refueling canal gate partitions the canal into two areas. One, the reactor cavity, encompasses the canal immediately above the vessel flange and canal seal plate, as well as one end of the canal. All vessel segmentation equipment would be placed here. The other area, behind the gate (and preferably containing the deeper end of the canal), would contain the cutting equipment and store the segments awaiting cask shipment.

The addition of this gate allows segmentation of the vessel to proceed in parallel with the internals segmentation. The canal would be flooded after installation of the necessary cutting equipment in the partitioned area; the internals would be removed from the vessel and set in-place on the cutting equipment. The canal gate is then lowered into position between the reactor and internals and the vessel cavity water level is lowered as required to support vessel segmentation. Figure 5.4-2 illustrates such a canal gate modification.

The canal gate would be a class I structure composed of carbon steel plate and standard I beams. During the design phase of a plant, the canal walls could be modified (e.g., slotted) to accept the gate. During decommissioning, a slotted rail of similar structure could be anchored to the canal wall to accept the gate and would probably be used in conjunction with an inflatable seal to insure its integrity. The gate will be designed for both live and dead loads, and probably for a seismic (earthquake) load.

\subsubsection{Cost Benefit Analysis}

An analysis was performed to investigate the desirability of installing a canal gate in the reference $P W R$ refueling canal in support of vessel/internals segmentation. First the cost, occupational radiation exposure, and waste volume generated under series removal/segmentation were estimated; then these same parameters were estimated for parallel operations assuming the existence of a canal gate.

The total of the vessel and closure head (with studs, nuts and washers), the vessel insulation, and the head ventilation shroud/lifting frame weighs approximately 904,700 pounds and contains $10,97 \emptyset$ curies of radioactivity. The vessel internals weigh $446,25 \emptyset$ pounds and contain $2,939,6 \emptyset \emptyset$ curies of radioactivity.

\subsubsection{Assumptions}

1 The reference PWR plant configuration is assumed (Ref. 5-1). 
FIGURE $5.4-2$

REFERENCE PWR WITH CANAL GATE MODIFICATION DURING SEGMENTATION

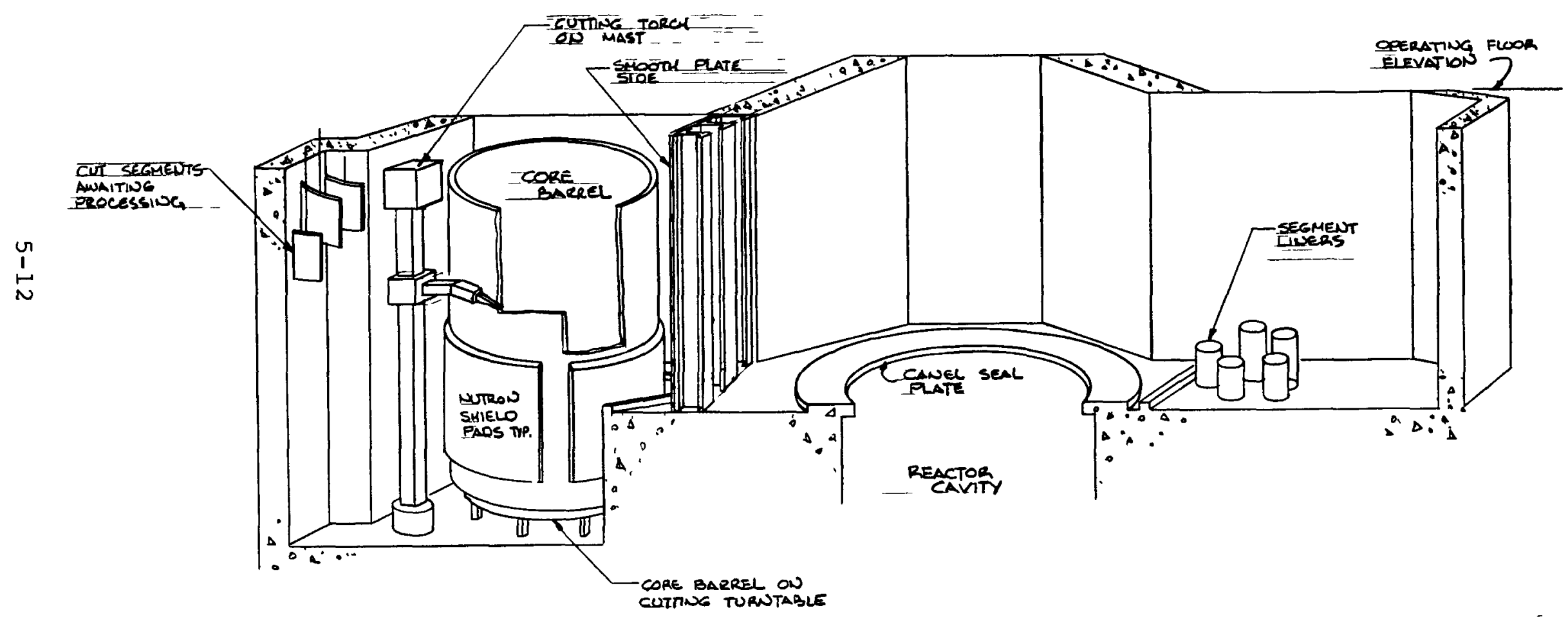


2. The reference PWR vessel and internals curie inventories are assumed.

3 The plant will be decommissioned by prompt dismantlement, requiring the complete removal of the vessel and internals.

4 Waste disposal fees are those from the 1984 schedule of the Barnwell, SC burial facility operated by Chem-Nuclear Systems, Inc. (Ref. 5-2).

5 Labor rates for crews used are those listed as the national average for skilled workers and helpers; foremen are assumed to have a $\$ 2 / \mathrm{hr}$ additional cost over the skilled worker average (Ref. 5-3).

6 All work performed is assumed to be done by a subcontractor and therefore a contractor overhead and profit factor of 1.6 is applied to all labor costs.

7 All radioactive waste is assumed shipped to a burial ground at 500 miles distance one-way.

\subsubsection{Base Case}

originally, the reactor internals are within, and the vessel closure head is fastened to the vessel. The closure head would be unbolted from the vessel flange and removed to its storage stand for removal of all CRD mechanisms, head service structure and platform, CRD cooling assembly ducting, etc. All required remote cutting equipment would be installed in the refueling canal; the canal is then flooded in preparation for internals removal. The internal components would be removed from the vessel, transferred to the cutting area and segmented. All segments would be placed in the appropriate cask liners as they are generated; liners are shipped as casks become available. After all internals are segmented and shipped, the water level would be lowered, required remote cutting equipment installed and the vessel segmentation initiated.

Vessel segments would be removed from the vessel, transferred in air to the loading area and loaded into cask liners. The liners are placed into casks as they become available, and shipped for burial.

The vessel disposal is estimated to require 51 cask shipments based on the authors' estimate using the NUREG/CR-ø13ø activation analysis. The closure head and lower vessel head will be shipped intact via railcar to the burial grounds. The total cost to dispose of the 
vessel is $\$ 3,646,600$; the total burial volume is $8644 \mathrm{cu}$ ft.

The vessel internals will require 105 cask shipments for disposal. The total cost to dispose of them is $\$ 9,243,300$; the total burial volume is $8778 \mathrm{cu} \mathrm{ft}$.

The total labor requirement for segmenting and packaging the vessel and internals is 54,840 manhours. The total occupational radiation exposure incurred by this labor is 332 manRem.

\subsubsection{Facilitation Case}

As with the base case, the reactor internals are within, and the vessel closure head is fastened to the vessel. The closure head would be unbolted and removed to its storage stand for removal of all equipment. All required remote cutting equipment would be installed in the refueling canal. The refueling canal would then be flooded in preparation for internals removal. The vessel internals components would be removed and transferred to the cutting area. The canal gate would be installed between the internals cutting area and the reactor cavity to isolate each section. The reactor cavity water level would be lowered, all required remote cutting equipment installed and the vessel segmentation initiated. All internals segments are stored in the canal until they are to be shipped. Vessel segments are removed from the reactor cavity area and transferred in air to the flooded internals cutting area, where they are stored until shipment. Vessel and internals segments are loaded into cask liners for shipment. As casks become available, the liners are placed into casks and shipped for burial.

The reactor vessel disposal will require 51 cask shipments. The closure head and lower RPV head are shipped intact via railcar to the burial grounds. The total cost to dispose of the reactor vessel is $\$ 3,527,700 ;$ the total burial volume is $8644 \mathrm{cu}$ ft.

The vessel internals will require 105 cask shipments for disposal. The total cost to dispose of the internals is $\$ 9,243,300$; the total burial volume is $8778 \mathrm{cu} \mathrm{ft}$.

The total labor requirement for segmenting and packaging the reactor vessel and internals is 46,360 manhours. The total occupational radiation exposure incurred by this labor is 279 manRem.

The overall dose for the facilitation case (279 manRem) is lower than the base case (332 manRem) because the 
- installation of the canal gate would reduce the time the segmentation crew is in a radiation field.

5.4.5 Conclusions

The major consideration in such an operation as reactor segmentation is safety; as such, the use of the canal gate is almost a necessity. The increased handing of vessel segments with possible contact radiation dose rates of up to $500 \mathrm{R} / \mathrm{hr}$ requires the use of shielding wherever possible.

It is also important to note that the simultaneous disposal of the reactor vessel and internals allows for potential volume reduction techniques such as cask homogenization (Section 3.6). (However, any impact to waste volume buried using such techniques has not been examined in this analysis.)

The canal gate could also assist operations personnel during the operating life of the plant by increasing the flexibility of response to unforseen circumstances. Work could be performed on the vessel (with internals removed) with workers at flange level, thereby greatly decreasing the difficulty of handling long-reach tools through an additional 30 feet of water.

The results of the analysis indicate that use of a canal gate will increase burial volume (due to burial of the gate after use); however, it will reduce both occupational radiation exposure and costs. These results are summarized in Table 5.4-1.

TABLE 5.4-1

ANALYSIS: CANAL GATE

$\begin{array}{ccccc}\text { Evaluation } & \text { Base } & \text { Facilitation } & \text { Net } & \text { Percent } \\ \text { Category } & \text { Case } & \text { Case } & \text { Reduction } & \text { Reduction }\end{array}$

Radiation

Exposure,

332

279

53

16

man Rem

Waste Volume,

cu ft:

Vessel

8644

8778

9186

8778

(542)

$(6.27)$

Internals

690

Vessel

$3,646,600$

$3,527,7 \emptyset \emptyset$

$9,243,360$

118,900

3. 3

Internals

$9,243,30 \emptyset$

$\emptyset$

$\emptyset . \emptyset$ 
5.5.1 Description

The containment and isolation of liquid spills is a critical element in effective contamination control. System piping leaks are usually caused by either design deficiencies in the containment system(s), absence of containment/controlling mechanisms or breakdown in administrative controls. Since the decontamination and removal of contaminated structures is a major work activity in power plant dismantling and a large contributor to the total waste volume from decommissioning, early preventative measures can minimize the spills and the magnitude of decontamination necessary. These measures are most easily implemented in the planning/ construction phase. During this phase, control measures can be instituted as design guidelines and incorporated as appropriate.

5.5 .2 objective

This technique was identified as a measure to prevent spills. This technique was examined to minimize waste volume and occupational exposure.

5.5.3 Approach and Methodology

Containment of liquids was evaluated with respect to the benefit derived during decommissioning in the decontamination of site structures. Attributing a percentage of the decontamination effort to primary containment failure during the facility's operational life, the potential impact was assessed assuming technique implementation. Consequently, the effect could be seen in radioactive waste volume and occupational exposure associated with decommissioning from a design/construction technique.

5.5.4 Cost Benefit Analysis

A cost benefit analysis was performed under the assumption that incorporating secondary containment features in facility design such as curbs or double valving reduced the contaminated surface area to be removed during decommissioning. For purposes of this analysis, a $10 \%$ reduction was assumed to be sufficient to determine the sensitivity effects of this facilitation technique. The remaining area was either unaffected by this design action or included the area within the secondary boundary. 


\section{$5.5 .4,1 \cdot$ Assumptions}

1 The materials and labor for decontamination activities are reduced in proportion to the decrease in potential contamination.

2 Concrete areas considered in this report are located in the reactor, auxiliary and radwaste buildings, the quantities representative for the reference $110 \emptyset$ Mwe power plant.

3 All containment features are instituted during the design phase with no appreciable cost impact because the volume of concrete for curbs or the number of double valves installed is relatively small compared to the initial construction cost.

4 National labor rates are used for the facilitation case (Ref. 5-3).

5.5.4.2 Base Case

Approximately $1 \varnothing \emptyset, \emptyset \emptyset \emptyset$ square feet of exposed concrete surface area may require some decontamination during the decommissioning process. of this total, approximately $10 \% \quad(10, \varnothing 0 \emptyset \mathrm{sq} f t)$ may require removal to a $2 "$ depth with the remainder requiring surface washing or etching. This process generates approximately 3,330 cu ft of LSA waste (burial volume) and an additional $50 \emptyset \emptyset$ gallons of liquid waste, representing another $570 \mathrm{cu} f t$ of as-buried LSA waste.

The personnel exposure in an average work area radiation field is expected to be $2.5 \mathrm{mR} / \mathrm{hr}$. Approximately $830 \emptyset$ manhours are expended in the radiation field, resulting in a total exposure of 20.8 manRem.

5.5.4.3 Facilitation Case

The technique was assumed implemented in the design stage. Table 5.5-1 lists some potential design improvements and suggested corrective actions. A 10\% reduction was realized in the potentially contaminated surface area. This produced a corresponding 10\% reduction in associated decontamination costs, generated waste volume and worker exposure.

5.5.5 Conclusions

As expected, the cost benefit analysis yielded savings in all areas. The actual savings will be very much dependent upon site specific considerations and cannot be quantified without identifying plant-specific 
TABLE 5.5-1

DESIGN IMPROVEMENTS FOR CONTROL/CONTAINMENT OF LIQUID SPILLS

Potential source

Suggested Action

Sump overflow
- Lower set point on high level alarm

- Increased sump capacity

- Installed reserve tankage

Automatic sump pump initiation with no available/adequate discharge reservoir

Cross connected/open floor drain system

Tank overflow
- Revert to manual intervention on high level indication

- Increase storage capacity

- Administrative controls on critical access points, e.g. caps/plugs

- Check valves to limit backflow

- Lower set point on high level alarm

- Tank cubicle design to contain at least one volume

- Overflow routed to supplemental tankage

- Containment surface protected from liquid migration

Embedded piping integ- - Double walled or sleeved piping rity loss

Spills/liquid migration - Curbing, dikes, protected and inclined surfaces 
scenarios. However, considering the minimal effort to incorporate these minor design changes, the effect on the decommissioning process should always be positive. The benefit assumed in the analysis is presented in Table 5.5-2.

TABLE $5 \cdot 5-2$

ANALYSIS: CONTROL AND CONTAINMENT OF LIQUID SPILLS

\begin{tabular}{|c|c|c|c|c|}
\hline $\begin{array}{l}\text { Evaluation } \\
\text { Category }\end{array}$ & $\begin{array}{l}\text { Base } \\
\text { Case }\end{array}$ & $\begin{array}{c}\text { Facilitation } \\
\text { Case }\end{array}$ & $\begin{array}{l}\text { Net } \\
\text { Reduction }\end{array}$ & $\begin{array}{c}\text { Percent } \\
\text { Reduction }\end{array}$ \\
\hline \multicolumn{5}{|l|}{ Radiation } \\
\hline $\begin{array}{l}\text { Exposure, } \\
\text { manRem }\end{array}$ & 20.8 & 18.7 & 2.1 & 10 \\
\hline $\begin{array}{l}\text { Waste Volume, } \\
\text { cu ft }\end{array}$ & 3,900 & 3,510 & 390 & 10 \\
\hline Cost, $\$$ & $526, \emptyset \emptyset \emptyset$ & $473,4 \emptyset \emptyset$ & $52,6 \emptyset \emptyset$ & 10 \\
\hline
\end{tabular}


5.6.1 Description

This technique is intended to reduce the occupational exposure associated with the demolition of radioactive monolithic concrete structures. This is accomplished by incorporating blasting holes during the construction of these structures prior to their contamination/activation.

\subsubsection{Objective}

The purpose of this cost benefit analysis is to determine the reduction in occupational exposure from this technique. The associated impact on cost and any deviation in waste volume generation as a result of this design change will also be examined.

5.6.3 Approach and Methodology

This analysis examined the activities involved in the incorporation of channels within monolithic concrete structures during their constuction. These channels would be used during the structures' demolition for the placement of explosive charges. The conventional demolition scenario of channels being bored out prior to blasting was used to quantify the reduction in occupational exposure and the effects on waste volume and costs incurred.

5.6.4 Cost Benefit Analysis

5.6.4.1 Assumptions

1 The structures selected for analysis are the sacrificial shield and reactor pedestal in the BWR and the biological/sacrificial shield in the reactor cavity area for the PWR.

2 Structural characteristics, dimensions and arrangement as well as expected radiological environment are taken from the reference plant descriptions for the decommissioning of a PWR and BWR, NUREG/CR- $\varnothing 130$ and $\emptyset 672$ (Ref. 5-1 and 5-4).

3 Determination of the impact on the generated waste volume is negated by keeping the geometric placement pattern identical for both the base case and the facilitation technique.

4 National labor rates and typical crews are used (Ref. 5-3). 
The base case provides for removal of massive radioactive concrete structures, such as the BWR biological/ sacrificial shield and the PWR reactor cavity, by controlled explosive demolition. To accomplish this it is necessary to drill holes in these stuctures to allow for insertion of blasting charges. As these structures are radioactive or are in radiation environments, workers will incur radiation exposure while drilling these holes at the time of decommissioning. This task can involve a significant expenditure of manpower to set up and drill holes for blasting. A large portion (nearly 100\%) of this manpower expenditure is spent in radiation fields either from the concrete being drilled or from nearby radiation sources.

Blast holes were arranged in concentric patterns to affect complete removal of the structures in the BWR and removal of only the activated zone in the PWR biological/sacrificial shield structure (the remaining substantial structure would probably be left in place). In the case of the PWR, the possibility of the presence of a Neutron Shield Tank (NST) was also accounted for in the determination of removal zones. The thickness of these structures is primarily determined on the basis of the shielding requirements so that plarement of these holes would not weaken the structure. Therefore, the safety implications are minimal.

5.6.4.3 Facilitation Case

Using the blast hole pattern established by the base case, the effect of preplacing these holes during the construction of these structures was evaluated. The blasting holes (voids) would be cast in-place during plant construction. Since the holes are perpendicular to the axial flux, the holes would not be filled but would be capped to maintain surface continuity and prevent the voids from becoming crud traps. Since all work will be performed during the construction phase, only costs were calculated (the potential exposure savings had already been calculated in the base case).

\subsubsection{Conclusions}

It was found that the technique of preplacing blast holes always produced a reduction in incurred occupational exposure. The degree of reduction in exposure was found to be dependent upon the radiation levels from or near the massive concrete structures and upon the size and geometry of the structure. 
The radiation exposures incurred for each application of the base and facilitation techniques and the exposure savings brought about by implementation of preplaced blast holes are shown in Table 5.6-1.

In general there is no effect on radioactive waste volume brought about by implementation of the facilitation technique. There may be a very slight reduction in the amount of contaminated protective clothing and coverings brought about by not having to drill in a contaminated work environment. This reduction is estimated to be only one or two cubic feet of contaminated materials.

Implementation of the facilitation technique was found to be cost effective in that it costs less to preplace blast holes that it does to drill them. In general, it is two to three times less expensive to preplace blast holes than to drill at the time of decommissioning.

TABLE 5.6-1

ANALYSIS: PREPLACED BLAST HOLES

\begin{tabular}{|c|c|c|c|c|c|}
\hline $\begin{array}{l}\text { Evaluation } \\
\text { Category }\end{array}$ & Item & $\begin{array}{l}\text { Base } \\
\text { Case }\end{array}$ & $\begin{array}{c}\text { Facilitation } \\
\text { Case }\end{array}$ & $\begin{array}{l}\text { Net } \\
\text { Reduction }\end{array}$ & $\begin{array}{l}\text { Percer } \\
\text { Reducti }\end{array}$ \\
\hline Radiation & PWR Cavity: & & & & \\
\hline $\begin{array}{l}\text { Exposure, } \\
\text { manRem }\end{array}$ & $\begin{array}{l}\mathrm{w} / \mathrm{NST} \\
\mathrm{w} / \mathrm{O} \quad \mathrm{NST}\end{array}$ & $\begin{array}{r}3 \\
72\end{array}$ & $\emptyset$ & $\begin{array}{r}3 \\
72\end{array}$ & $\begin{array}{l}10 \emptyset \\
10 \emptyset\end{array}$ \\
\hline & $\begin{array}{l}\text { BWR Shield } \\
\text { BWR Pedestal }\end{array}$ & $\begin{array}{r}35 \\
160\end{array}$ & $\emptyset$ & $\begin{array}{r}35 \\
160\end{array}$ & $\begin{array}{l}10 \emptyset \\
10 \emptyset\end{array}$ \\
\hline Cost, $\$$ & $\begin{array}{l}\text { PWR Cavity: } \\
\text { w/ NST } \\
\text { w/o NST }\end{array}$ & $\begin{array}{l}15,300 \\
41,400\end{array}$ & $\begin{array}{l}11, \varnothing \emptyset \emptyset \\
29,7 \emptyset \emptyset\end{array}$ & $\begin{array}{r}4,300 \\
11,700\end{array}$ & $\begin{array}{l}28 \\
28\end{array}$ \\
\hline & $\begin{array}{l}\text { BWR Shield } \\
\text { BWR Pedestal }\end{array}$ & $\begin{array}{l}20,500 \\
92,700\end{array}$ & $\begin{array}{l}14,7 \emptyset \emptyset \\
66,5 \emptyset \emptyset\end{array}$ & $\begin{array}{r}5,8 \emptyset \emptyset \\
26,20 \emptyset\end{array}$ & $\begin{array}{l}28 \\
28\end{array}$ \\
\hline
\end{tabular}


5.7 SMOOTH AND COAT CONCRETE SURFACES

5.7.1 Description

The technique was identified to effectively decrease the radwaste associated with the decontamination of contaminated structures using preventive/protective measures (i.e., the smoothing and coating of concrete surfaces.

5.7 .2 objective

The purpose of this cost benefit analysis is to determine the reduction in burial volume associated with the change in concrete decontamination methods from destructive blasting, chipping and grinding to nondestructive methods, washing and stripping (protective film). The associated costs and any reduction in occupational exposure will also be evaluated.

5.7.3 Approach and Methodology

The analysis examined the activities involved in the protection of concrete surfaces in areas with high contamination potential (e.g., the reactor, auxiliary and radwaste buildings). These potentially contaminated surfaces would be smoothed and coated. The effectiveness of this treatment on decontamination requirements was evaluated relative to the base case of bare concrete surfaces.

\subsubsection{Cost Benefit Analysis}

\subsubsection{Assumptions}

1 Concrete areas considered in this report are located in the reactor, auxiliary and radwaste buildings. The quantities are taken from the reference 1100 MWe power plant.

2 National labor rates and typical crews are used for the facilitation case (Ref. 5-3).

3 All concrete finishing work is performed during the construction phase with the exception of periodic surface coating maintenance during plant operations.

4 Waste disposal fees of $\$ 36 / c u$ ft of waste are used. This fee includes container cost, transportation fees and burial ground fees.

5 All coatings inside containment should be qualified and meet Regulatory Guide 1.54 (Ref. 5-5) and ANSI 101.2 (Ref. 5-6) requirements. 
5.7.4.2 Base Case

Approximately 100,000 sq ft of exposed concrete surface area may require some decontamination during the decommissioning process. of this total, approximately $1 / 1 \emptyset(10, \emptyset \emptyset \emptyset$ sq $f t)$ requires removal to a $2 "$ depth with the remainder requiring surface washing or etching. This process generates approximately $3,330 \mathrm{cu}$ ft of LSA waste (burial volume) and an additional $500 \emptyset$ gallons of liquid waste, representing another $570 \mathrm{cu}$ ft of as-buried LSA waste.

The personnel exposure in an average work area radiation field is expected to be $2.5 \mathrm{mR} / \mathrm{hr}$. Approximately $830 \emptyset$ manhours are expended in the radiation field, resulting in a total exposure of 20.8 manRem.

\subsubsection{Facilitation Case}

The high probability concrete area was trowel-floated to a smooth finish and then sealed with two layers of an epoxy sealer. Approximately $20 \%$ of the area was assumed to be recoated during the operational lifetime of the facility due to wear and maintenance activities. The aforementioned program reduced destructive decontamination to $10 \%$ of the base case. This reduction affected both the associated waste volume and occupational exposure. Maintenance radiation fields were taken at 5 $\mathrm{mR} / \mathrm{hr}$ during plant operations.

\subsubsection{Conclusions}

The cost benefit analysis yielded a savings in waste volume and net cost (marginal). There was an overall increase in exposure due to the maintenance requirements of the coating system. The results are shown in Table 5.7-1. Confining this technique to very highprobability, low-traffic usage areas would minimize maintenance of the coating and the associated worker exposure, making the technique more acceptable in this area. 
TABLE $5 \cdot 7-1$

ANALYSIS: SMOOTH AND COAT CONCRETE SURFACES

\begin{tabular}{|c|c|c|c|c|}
\hline $\begin{array}{l}\text { Evaluation } \\
\text { Category }\end{array}$ & $\begin{array}{l}\text { Base } \\
\text { Case }\end{array}$ & $\begin{array}{c}\text { Facilitation } \\
\text { Case }\end{array}$ & $\begin{array}{l}\text { Net } \\
\text { Reduction }\end{array}$ & $\begin{array}{c}\text { Percent } \\
\text { Reduction }\end{array}$ \\
\hline $\begin{array}{l}\text { Radiation } \\
\text { Exposure, } \\
\text { manRem }\end{array}$ & 20.8 & 56.9 & $(36.1)$ & $(117)$ \\
\hline $\begin{array}{l}\text { Waste Volume, } \\
\text { cu ft }\end{array}$ & 3,900 & 900 & $3, \varnothing \emptyset \emptyset$ & 77 \\
\hline Cost, $\$$ & 526,000 & $507,4 \varnothing \emptyset$ & $18,60 \emptyset$ & 4 \\
\hline
\end{tabular}


5.8.1 Description

Certain isotopes present in a nuclear power plant generate radiation dose rates far out of proportion to their fraction of total radioactivity; such an isotope is cobalt-6ø, a major contributor to the total occupational exposure in power plant decommissioning. If the amounts of cobalt-6ø could be reduced the occupational exposure should also decrease. other isotopes with similar impacts to a lesser degree are Nickel-63 (beta emitter) and Manganese-54 (gamma emitter) (Ref. 5-7). Reduction in the curie content may also decrease the disposal and/or burial volumes of the contaminated/activated components.

5.8.2 Objective

This technique was identified to investigate any potential reduction in occupational radiation exposure, waste volume to be buried and cost for removal by altering the composition of materials used in radiation environments.

5.8.3 Approach and Methodology

Current designs of PWR and BWR reactor vessels and internals are comprised of the following metals:

- $\quad 304 / 304 \mathrm{~L} / 316$ Austenitic stainless steels

- Carbon steel (SA533 and other grades)

- Inconel

- Zircaloy 2 and 4

- Stellite 6

In all of the above metals, the major dose contributor in the range of 2 to $1 \emptyset \emptyset$ years after final shutdown of the reactor is cobalt-6ø with a half life of 5.27 years. Cobalt-6ø is formed by neutron capture of $10 \emptyset \%$ prevalent Cobalt-59, the natural form of cobalt.

Cobalt-6ø is present only as a trace contaminant from the nickel and/or iron constituents in the zircaloys, inconel, stainless and carbon steels. In these cases, cobalt reduction can be accomplished by performing assays of the stock (plate, bar, sheet, etc.) prior to component fabrication and selecting stock with the lowest available content of cobalt. Since cobalt is a trace contaminant, its concentration can vary widely, by approximately one and one-half orders of magnitude. 
Further reductions in the content of cobalt are technically possible but would involve development of new processes to chemically separate the cobalt from the melt during the stock materials fabrication. The cost, complexity and schedule impact of developing such processes, getting ASTM code approval on the material and its method of fabrication, and getting ASME code revisions to permit its use in N-stamped components would seem to negate the chances of further reductions.

Cobalt is present as a hardening agent in the alloy of stellite 6 ; as such it cannot be totally removed. potential reductions are small, mainly from selecting stock low in cobalt contaminants. The same result can be obtained by incorporating the cobalt present as contaminants into the total requirements of the alloy. Cobalt lends certain favorable characteristics to the alloys (e.g., hardness/toughness, corrosion resistance, etc.) requiring its presence in the alloy (Ref. 5-8).

5.8.4 Cost Benefit Analysis

A cost benefit analysis was performed under the assumption that $5 \emptyset \%$ of the cobalt could be eliminated from the vessel internals (Type 304) stainless steel stock through prudent selection of the available stock at the time of manufacture. A reduction of $25 \%$ of the cobalt present in the carbon steel (grade SA533) reactor vessel base metal was also assumed.

\subsubsection{Assumptions}

1 A Westinghouse 3411 MWth (1100 MWe) nuclear reactor vessel and internals assembly is used.

2 The activation analysis present in NUREG/CR- $\emptyset 13 \emptyset$ is used to determine curie contents.

3 All curie contents are decayed to two years beyond final shutdown from the NUREG/CR-ø13ø curie contents.

4 other than first selecting the stock material for low cobalt content in accordance with the material assays, no additional costs for tracking are necessary other than already required standard $Q A$ requirements for nuclear reactors or other $\mathrm{N}$-stamped Category 1 components.

5 Waste disposal fees are those from the 1984 schedule of the Barnwell, SC burial facility. 
Waste disposal fees not listed on the 1984 ' schedule are those supplied directly by Barnwell facility personnel.

7 Labor rates for crews used in the vessel and internals cutting operation are those listed as the national average for skilled workers and helpers; foremen are assumed to have a $\$ 2 . \emptyset \emptyset /$ hr additional cost over the skilled worker average (Ref. 5-3).

8 All work performed is assumed to be done by a subcontractor and therefore a contractor overhead and profit factor of 1.6 is applied to all labor costs.

9 All radioactive waste is assumed shipped to a burial ground at $50 \emptyset$ miles distance, one-way.

10 All control rod drives, cooling fan units and ducts, and head service structure components are removed and disposed of separately.

11 All cask shipments are made by truck using licensed, currently available shielded casks meeting existing limits of the burial grounds.

\subsubsection{Base Case}

The reactor vessel and closure head, with closure head studs, nuts and washers, as well as the vessel insulation and the head ventilation shroud and lifting frame, weighs approximately 904,700 pounds. It contains $10,97 \varnothing$ curies of radioactivity; this will require 51 cask shipments for disposal. The closure head and lower RPV head are shipped intact via railcar to the burial grounds. The total cost to dispose of the reactor vessel is $\$ 3,527,7 \emptyset \emptyset$. The total burial volume is 8644 cu ft.

The vessel internals weigh 446,250 pounds. They contain $2,939,60 \emptyset$ curies of radioactivity and will require 105 cask shipments for disposal. The total cost to dispose of the internals is $\$ 9,243,300$. The total burial volume is $8778 \mathrm{cu} \mathrm{ft}$.

The total labor requirement for segmenting and packaging the reactor vessel and internals is 46,360 manhours. The total occupational radiation exposure incurred by this labor is 279 manRem (assuming the canal gate facilitation technique is used). 
5.8.4.3. Facilitation Case

The reactor vessel and closure head, with closure head studs, nuts and washers, as well as the reactor vessel insulation and the head ventilation shroud and lifting frame, contains $10,80 \emptyset$ curies of radioactivity; these components will be disposed of by burial and will require 51 cask shipments. The closure head and lower RPV head will be shipped intact via railcar to the burial grounds. The total cost to dispose of the reactor vessel is $\$ 3,489,700$. The total burial volume is 8644 cu $\mathrm{ft}$.

The cost to implement the facilitation technique is estimated to be approximately $\$ 10, \emptyset \emptyset \emptyset$, with no penalty to exposure or burial volume. The cost is for manpower and travel expenses to select the stock material with lowest available cobalt from the available stock at various steel companies. The addition of this cost of implementation brings the true cost for removal to $\$ 3,499,7 \emptyset \emptyset$ for the reactor vessel.

Most of the curie and cost reductions from the base case are due to the stainless steel cladding of the reactor vessel. The vessel carbon steel base case metal contains little cobalt, therefore experiencing little change from the assumed reduction in cobalt.

The reactor vessel internals contain $2,516,64 \emptyset$ curies of radioactivity, disposed of in 96 cask shipments. The total cost to dispose of the internals is $\$ 8,344,800$. Adjusting the actual cost to include the cost to implement (approximately $\$ 1 \emptyset, \emptyset \emptyset \emptyset$ ) yields a total removal cost for the reactor internals of $\$ 8,354,800$. The total burial volume is $8166 \mathrm{cu} \mathrm{ft}$.

The total labor requirement for segmenting and packaging the reactor vessel and internals is 44,080 manhours. The total occupational radiation exposure incurred by this labor is 263 manRem.

\subsubsection{Conclusions}

The cost benefit analysis indicates positive reductions in all three evaluation categories for the reactor internals, while indicating low, but still positive reductions in waste volume and cost and no change in the volume for the reactor vessel.

There is virtually no experience regarding the costs for vessel/internals manufacturers to provide low-cobalt steels. For the reactor vessel, the $\$ 10,000$ estimate to implement this technique may not be sufficient to 
achieve the $\$ 28, \emptyset \emptyset \emptyset$ net reduction shown in 'Table' 5.8-1. However, for the vessel internals, Table 5.8-1 shows up to $\$ 888,467$ could be spent to achieve the waste volume and exposure reduction.

Since the reactor vessel and internals are segmented and handled remotely underwater, reduction in curie contents has only a small impact on the exposures to segmentation personnel. The reduction that occurs is due to the reduced duration of cutting and segmenting the internals, since fewer shipments are required to dispose of the vessel internals with their lower curie contents.

Given the expected low cost to implement this technique in the scenario described, its use is recommended for the reactor internals. As for the reactor vessel, the low reductions possible, combined with the accuracy of the assumptions used (as well as the even lower potential reductions if the vessel stainless steel cladding is factored out), indicates limited potential use for low cobalt carbon steel. These results are summarized in Table 5.8-1.

TABLE 5.8-1

ANALYSIS: SUBSTITUTION AND PURIFICATION OF MATERIALS

Evaluation Category
Base

Case

279

Exposure,

man Rem

Waste Volume,

cu ft:

Vessel

Internals

Cost, \$:

Vessel

Internals
$3,527,700$

$9,243,300$
8644

8778
Facilitation Case

\section{Net Reduction Reduction \\ Percent}

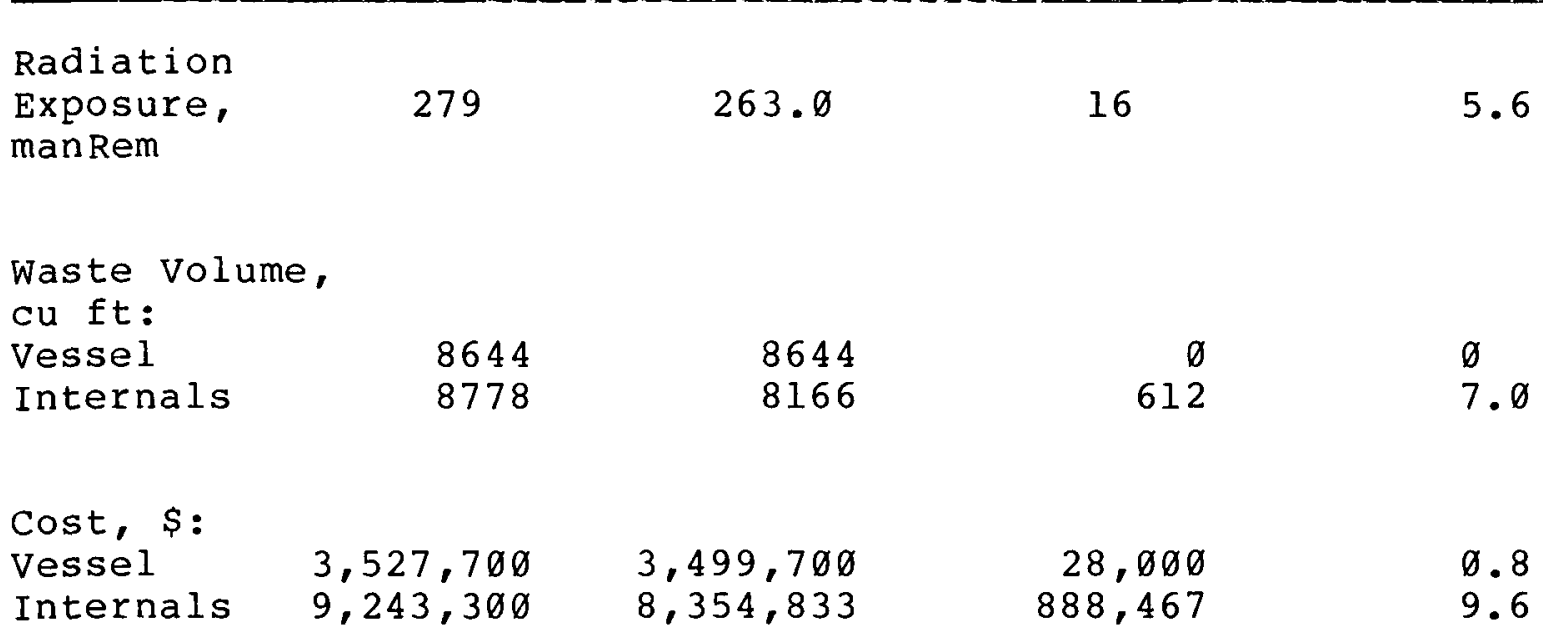


5.9 MODULAR CONSTRUCTION OF THE BIOSHIELD

5.9.1 Description

This technique was identified to decrease the waste volume requiring controlled disposal, and the personnel exposure incurred from demolition of the activated concrete in the biological shield during the dismantling process. This technique has several analytical, practical and licensing difficulties that may prohibit its feasibility and use. The technique was included in the cost benefit analysis because it was suggested by several technique contributors and therefore warranted identification of these potential problems.

\subsection{2 objective}

The purpose of this cost benefit analysis is to determine the reduction in net burial volume and occupational exposure in the dismantling process from a change in design construction of the shield walls from monolithic to integrated segments.

5.9.3 Approach and Methodology

The analysis involved calculating the effect of changing the design configuration of the shield walls to that of integrated segments to enable controlled/nondestructive dismantling (as opposed to an alternative such as blasting) of the activated portions of the structures. Three basic alternative configurations for shield wall construction were analyzed; 1) small block construction, 2) ringed segments, and 3) interlocking slab construction. Each was compared against the base case for savings in the resultant waste volume during the dismantling process.

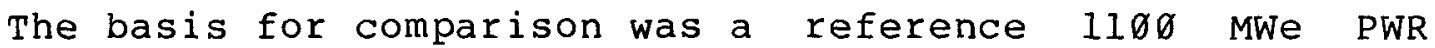
with a typical reactor cavity/biological shield arrangement and an expected neutron flux profile and corresponding activation pattern for the power rating and construction configuration. In the case of the BWR the design of the sacrificial shield was not adaptable to modularization. No steel liner was assumed in the cavity for these analyses.

The removal, packaging and shipping baseline used for comparison was the typical disposition analysis used in decommissioning studies in calculating plant removal costs. 
5.9.4 Cost Benefit Analysis

5.9.4.1 Assumptions

1 The base case PWR NUREG/CR-ø130.

bioshield design is taken from

2 Staggered blocks and stepped slabs are fully streaming.

3 Seismic design considerations are not limiting, or can be reinforced to meet the design seismic event. While no quantitative analyses were prepared to support this assumption, the qualitative feasibility of this technique is discussed in the conclusions.

5.9.4.2 Base Case

The base case for this cost benefit analysis was the PWR biological shield consisting of a heavily reinforced as-cast concrete shield surrounding the reactor vessel. Typical removal would be by controlled blasting and the rubble disposed of by packaging, shipping and burial in a controlled burial ground. The volume of the installed as-cast shield is $6 \emptyset 50$ cu ft. The volume disposed of including the rubble void factor (approximately 50\%) and burial container with attachments is approximately $15,50 \emptyset$ cu ft. The volumes of construction and disposal, and the costs to construct, demolish and dispose of the shield are shown in Table 5.9-1.

TABLE 5.9-1

AS-CAST BIOSHIELD BASE CASE

Evaluation Category

Volume, cu ft

Cost, $\$$
Construction

$6,05 \varnothing$

144,528
Demolition

\& Disposal

5.9.4.3 Facilitation Case

The facilitation case considered modular blocks/slabs for the bioshield installed during the construction 
phase. The alternative design configurations shown in Figures 5.9-1 (a thru d) were analyzed for the associated reduction in waste volume and costs from the controlled demolition base case. The facilitation case permits reducing the removal of nonactivated/contaminated concrete by segregating the activated sections without cross-contaminating clean sections. The analysis assumes the modular shield could be seismically restrained and that the activation of additional reinforcing/ structural steel did not preclude the handling of the activated sections by normal methods.

The volumes of construction of each type of shield, and the removal and disposal costs for each modular design are shown in Table 5.9-2.

TABLE 5.9-2

MODULAR BIOSHIELD FACILITATION CASE

\begin{tabular}{lccc} 
Shield Design & $\begin{array}{c}\text { Volume } \\
(\mathrm{cu} f t)\end{array}$ & $\begin{array}{c}\text { Construction } \\
\text { Cost }(\$)\end{array}$ & $\begin{array}{c}\text { Removal } \\
\text { \& Disposal } \\
\text { Cost }(\$)\end{array}$ \\
\hline $\begin{array}{l}\text { Keyed Blocks } \\
\begin{array}{l}4,20 \emptyset \\
\text { Rings }\end{array}\end{array}$ & 272,034 & 138,544 \\
$\begin{array}{l}\text { Rectangular } \\
\text { Slabs }\end{array}$ & 7,450 & 304,419 & 155,036 \\
$\begin{array}{l}\text { Octagonal } \\
\text { Slabs }\end{array}$ & 6,150 & 482,537 & 245,747 \\
\end{tabular}

\subsubsection{Conclusions}

In both the keyed block and ring scenarios the volume to be removed by separating out the activated portion of the biological shield was less than that removed by controlled blasting. This was a result of being able to remove only the activated block selectively without cross-contamination than was possible for blasting. The slab geometries yielded higher removal volumes; however, since they were removed essentially intact there was no additional volume expansion from void fractions except for that necessitated by packaging. In the case of custom packaging, the volume removed in all options is essentially the same as the volume of the block or slab. 
FIGURE 5.9-1a

MODULAR BIOLOGICAL SHIELD: KEYED BLOCK CONFIGURATION

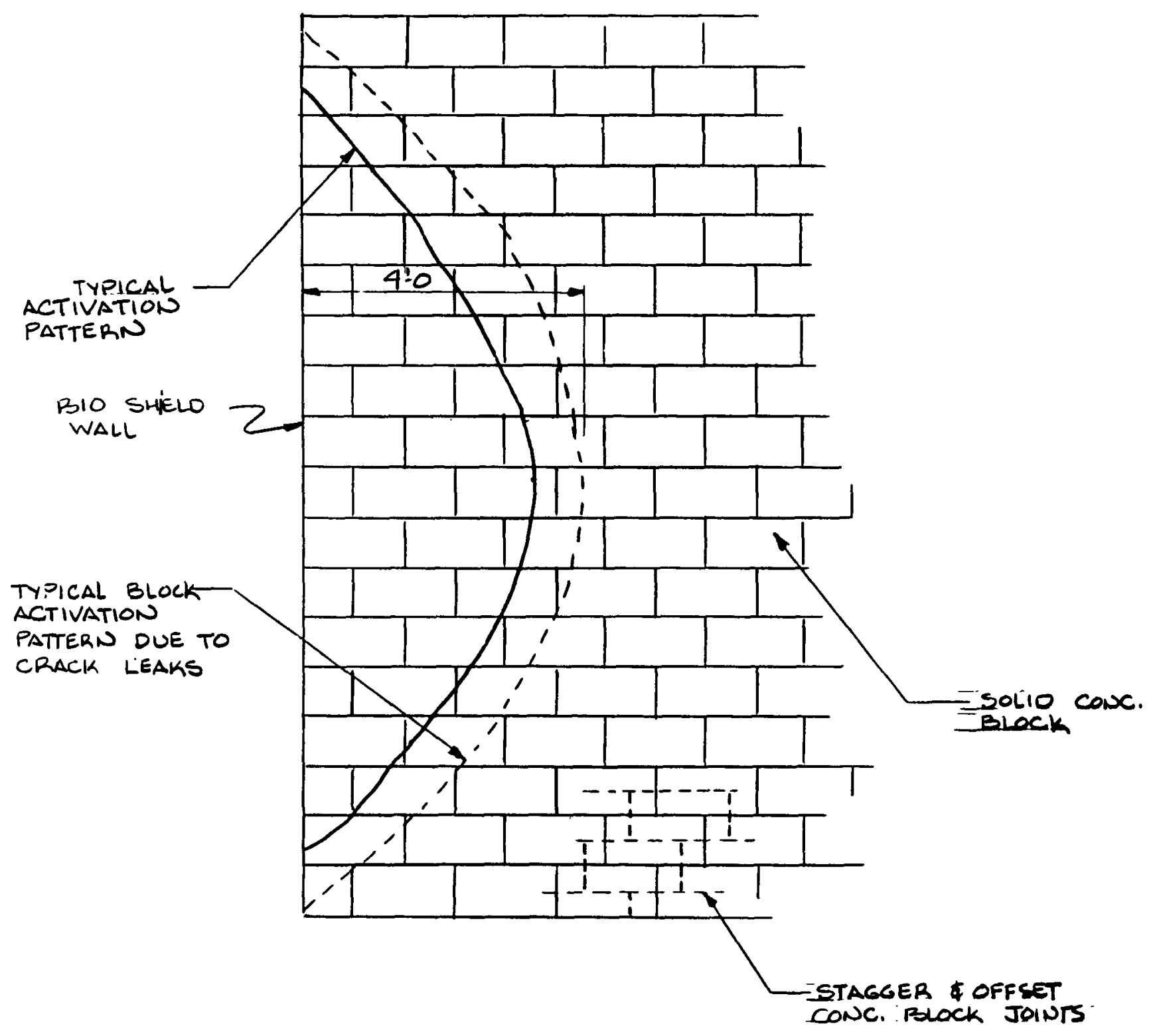


MODULAR BIOLOGICAL SHIELD: RING CONFIGURATION
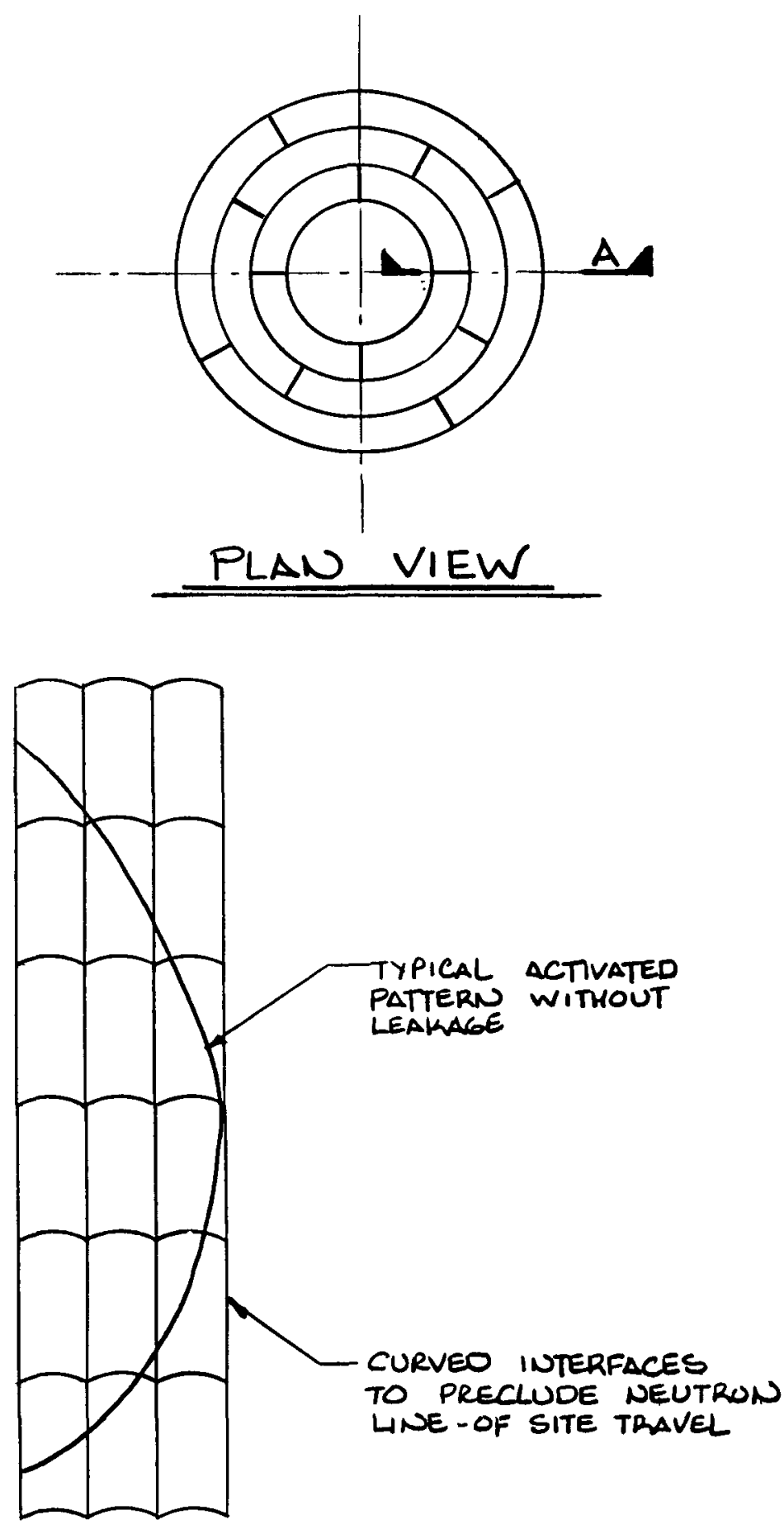

SECTION "A" 
FIGURE 5.9-1c

MODULAR BIOLOGICAL SHIELD: RECTANGULAR SLAB CONFIGURATION

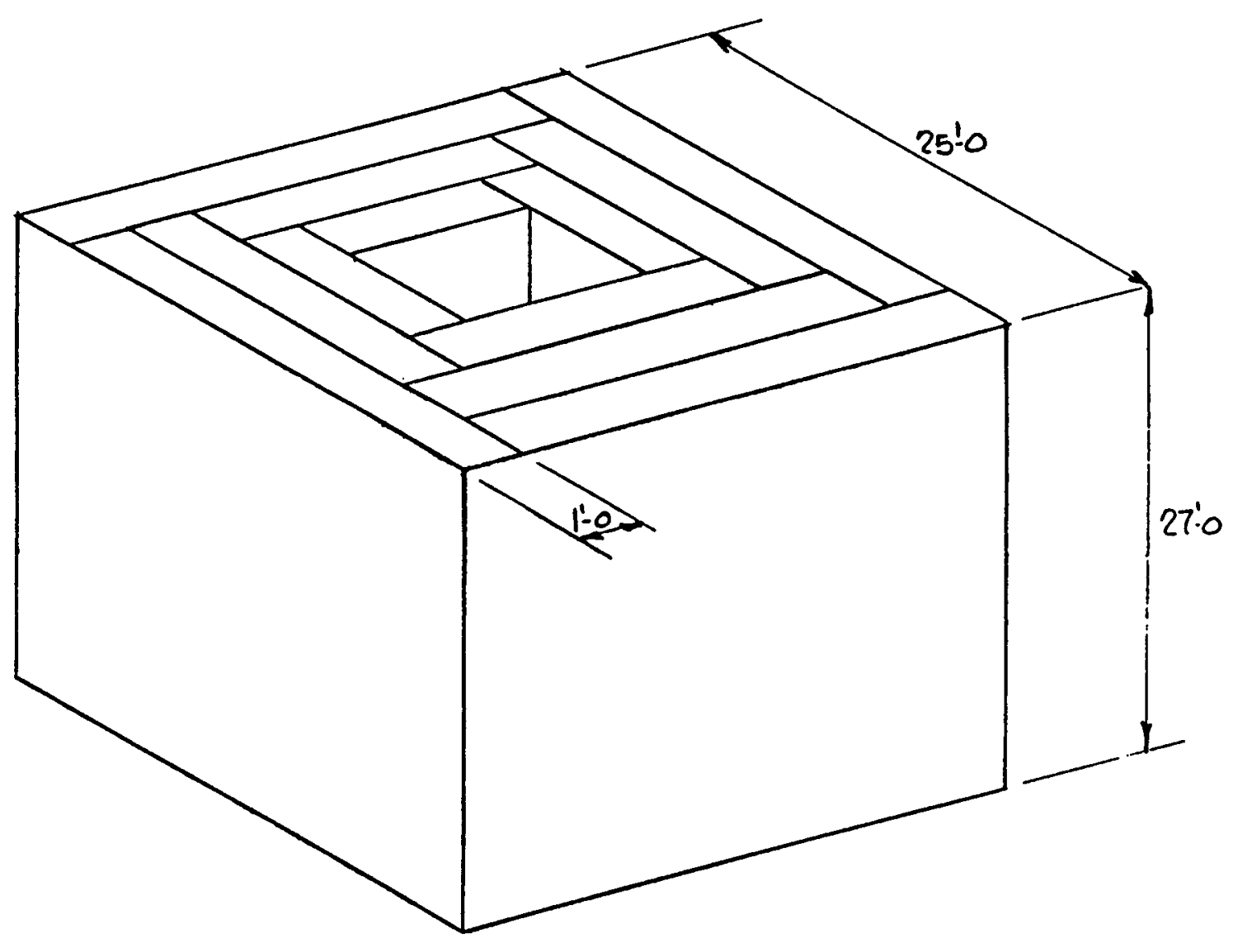

20:0 $\times 20: 0$ CENTER Volo 


$$
\text { FIGURE } 5 \cdot 9-1 d
$$

MODULAR BIOLOGICAL SHIELD: OCTAGONAL SLAB CONFIGURATION

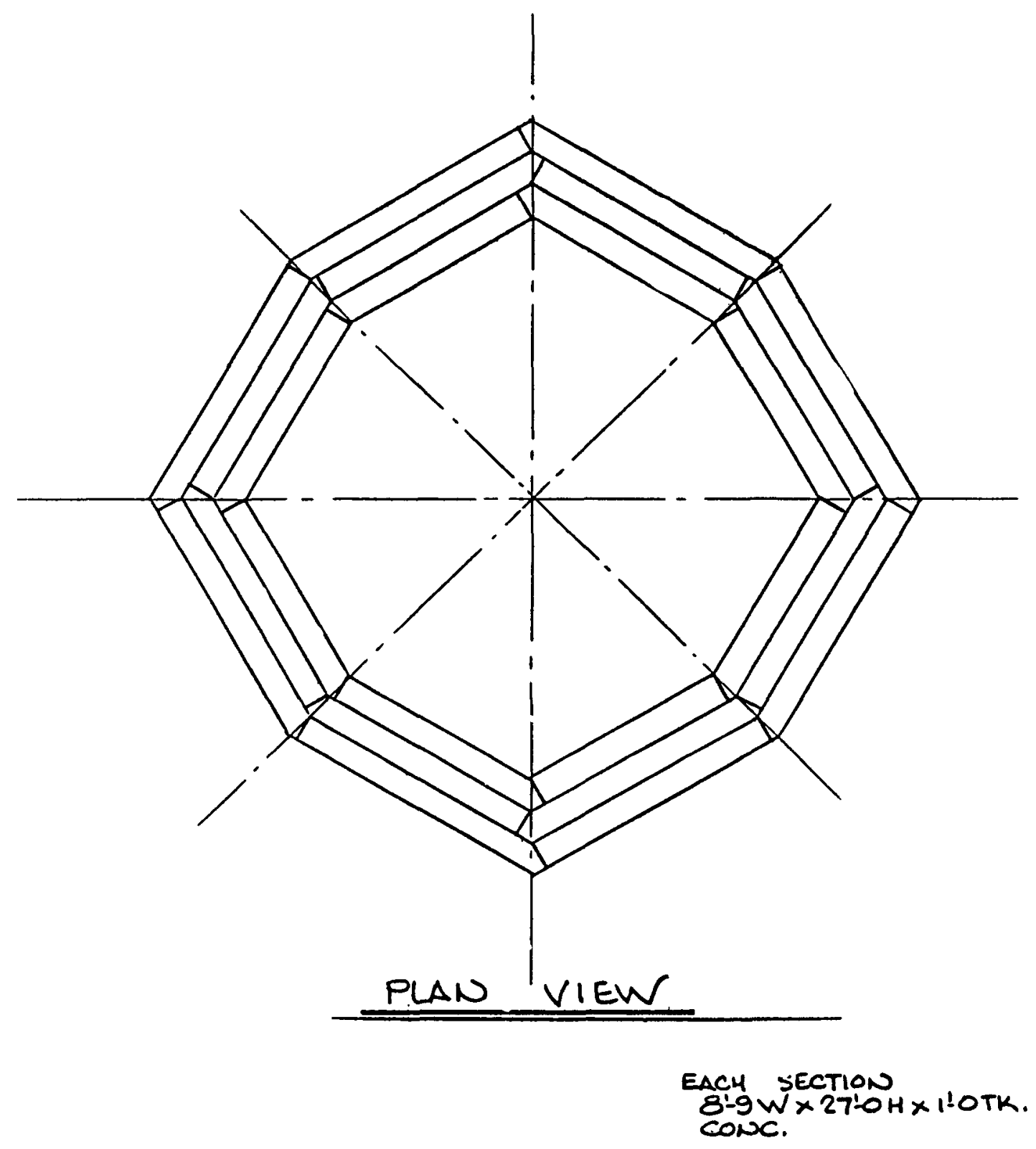


Table 5.9-3 summarizes the cost benefit analysis results. Note that the exposure to workers in the facilitation case is very nearly the same as in the base case, and therefore was not included in the analysis.

Theoretically, the modular bioshield concept can reduce the volume of concrete removed during biological shield decontamination. However, due to the limitations of applicability in a commercial power reactor, the concept may have 1 ittle practical application.

TABLE 5.9-3

ANALYSIS: MODULAR BIOSHIELD

\begin{tabular}{|c|c|c|c|c|c|}
\hline $\begin{array}{c}\text { Evaluation } \\
\text { Category }\end{array}$ & $\begin{array}{l}\text { Base } \\
\text { Case }\end{array}$ & $\begin{array}{r}\text { Faci } \\
\text { C }\end{array}$ & $\begin{array}{l}\text { itation } \\
\text { se }\end{array}$ & $\begin{array}{l}\text { Net } \\
\text { Reduction }\end{array}$ & $\begin{array}{c}\text { Percent } \\
\text { Reduction }\end{array}$ \\
\hline $\begin{array}{l}\text { Waste Volume, } \\
\text { cu ft } \\
\text { Construction }\end{array}$ & 6050 & $\begin{array}{l}\text { K Blocks } \\
\text { Rings } \\
\text { R Slabs } \\
\text { O Slabs }\end{array}$ & $\begin{array}{l}420 \emptyset \\
470 \emptyset \\
745 \emptyset \\
615 \emptyset\end{array}$ & $\begin{array}{r}1850 \\
1350 \\
(1400) \\
(100)\end{array}$ & $\begin{array}{c}30.6 \\
22.3 \\
(23.1) \\
(1.7)\end{array}$ \\
\hline $\begin{array}{l}\text { Demolition \& } \\
\text { Disposal }\end{array}$ & $15,5 \emptyset \emptyset$ & $\begin{array}{l}\text { K Blocks } \\
\text { Rings } \\
\text { R Slabs } \\
\text { O Slabs }\end{array}$ & $\begin{array}{l}4200 \\
470 \emptyset \\
7450 \\
6150\end{array}$ & $\begin{array}{r}11,300 \\
10,800 \\
8050 \\
9350\end{array}$ & $\begin{array}{l}72.9 \\
69.7 \\
51.9 \\
60.3\end{array}$ \\
\hline $\begin{array}{l}\text { Cost, } \$ \\
\text { Construction }\end{array}$ & 144,528 & $\begin{array}{l}\text { K Blocks } \\
\text { Rings } \\
\text { R Slabs } \\
\text { O Slabs }\end{array}$ & $\begin{array}{l}272,034 \\
304,419 \\
482,537 \\
398,336\end{array}$ & $\begin{array}{l}(127,506) \\
(159,891) \\
(338,009) \\
(253,808)\end{array}$ & $\begin{array}{l}(88.2) \\
(110.6) \\
(233.9) \\
(175.6)\end{array}$ \\
\hline $\begin{array}{l}\text { Demolition } \delta \\
\text { Disposal }\end{array}$ & 663,836 & $\begin{array}{l}\text { K Blocks } \\
\text { Rings } \\
\text { R Slabs } \\
\text { O Slabs }\end{array}$ & $\begin{array}{l}138,544 \\
155,036 \\
245,747 \\
2 ø 2,866\end{array}$ & $\begin{array}{l}525,292 \\
5 \emptyset 8,800 \\
418, \emptyset 89 \\
460,97 \emptyset\end{array}$ & $\begin{array}{l}79.1 \\
76.7 \\
63.0 \\
69.4\end{array}$ \\
\hline
\end{tabular}

Application may be possible in small test reactors and/or low power facilities where the biological shield has a limited or minimal structural role and where ease of disassembly is desired.

In the case of the BWR, the design of the sacrificial shield was not adaptable to a modularized design. The shield structure in a PWR initially apppeared suitable and the volume reduction potential significant; however, a feasibility review indicated problems with incorporation of the concept within present plant design and 
planned dismantling sequences. The major reservations with technique applicability are listed herein.

1 The upper portion of the modular shield may interfere with RPV nozzle/RCS piping penetrations.

2 In some designs the biological shield concrete ultimately supports the RPV (on those vessels supported by the nozzles).

3 The increased amount of steel necessary to tie the modular sections together presents an additional target for neutron activation, producing higher radiation fields in the cavity during operation and dismantling.

4 Direct access to the modular portion of the shield is limited to the cavity and is not accessible from above (the refueling canal floor) since the modular segments are associated with the activation zone and do not extend significantly above the inlet nozzles, necessitating a difficult horizontal removal/rigging procedure.

5 Shipments of modular segments will exhibit higher radiation readings than the packages containing homogenized blast rubble, presenting a greater radiological hazard and complicating handling; disposition extraction of secondary layers of keyed shield segments may require substantial removal of nonactivated concrete for access, possibly unnecessary otherwise.

6 Sealing the modular shield/cavity interface complicates eventual dismantling; however, failure to seal this interface will greatly increase the contamination potential of the segments during vessel cutting and could conceivably cause additional shield activation by presenting pathways for neutron streaming.

The practicality and feasibility of this technique is severely limited by these considerations. The difficult analytical, mechanical, seismic, handling and licensing problems would have to be addressed on a site-specific basis. 
5-1 R.I. Smith, et al., "Technology, Safety and costs of Decommissioning a Reference Pressurized Water Reactor Power Station," NUREG/CR-ø13ø, U.S. Nuclear Regulatory Commission, 1978.

5-2 Chem-Nuclear Systems, Inc., "Barnwell Low-Level Radioactive Waste Disposal Facility Rate Schedule," January 1, 1984 .

5-3 "Building Construction Cost Data 1984," 42nd Annual Edition, Robert Snow Means Company, Inc., 1984.

5-4 H.D. Oak, et al., "Technology, Safety and Costs of Decommissioning a Reference Boiling water Reactor Power Station," NUREG/CR-ø672, U.S. Nuclear Regulatory Commission, 1980 .

5-5 U.S. Nuclear Regulatory Commission, Regulatory Guide 1.54, "Quality Assurance Requirements for Protective Coatings Applied to Water-Cooled Nuclear Power Plants," 1973.

5-6 American National Standards Institute, Nløl.2, "Protective Coatings (Coatings for Light Water Nuclear Reactor Containment Facilities)," 1972.

5-7 J.C. Evans, et al., "Long-Lived Activation products in Reactor Materials," NUREG/CR-3474, U.S. Nuclear Regulatory Commission, 1984 .

5-8 Brady and Clauser, "Materials Handbook," 11th Edition, McGraw-Hill Inc., 1977. 


\section{EVALUATION SUMMARY AND RANKING OF TECHNIQUES}

Chapters 3 through 5 present a synopsis of facilitation techniques applicable to each of the three stages of plant life. These chapters provide a detailed description of all techniques and, where applicable, a discussion of the cost benefit analysis and its subsequent results. This chapter presents a summary of the results of those Good Practice and cost Benefit evaluations. For each technique with detailed cost benefit analyses, this chapter also presents a ranking in respect to exposure reduction, waste volume reduction and cost.

\subsection{SUMMARY OF RESULTS}

As discussed in Chapter 2, 59 techniques were identified as methods of facilitating reactor decommissioning. The majority of these facilitation techniques were applicable during the design/construction or decommissioning phases of plant life.

A majority of the techniques were also categorized as Good Practice. Table 6.1-1 presents a compilation of these Good Practice facilitation techniques for each reactor life stage. Techniques 1 isted as Good practice met one or more of the following rationale:

- Technique or generic methodology had been shown successful in past applications at facilitating the decommissioning process with respect to the goals as defined for this program;

- Technique had been recommended as a corrective action or as a process enhancement as a result of previous decommissioning programs; or

- Technique had indisputable potential, the magnitude of the return being dependent upon the extent of application.

Actual benefits (exposure, waste volume and cost reduction) were not determined because of each technique's wide application on a site-specific basis. However, some positive benefit would be achieved when applying these techniques to a particular site. Since the actual benefits could not be detailed, these techniques were rated using the relative rating system described in section 2.6. In summary, this relative rating system is delineated as follows: 
TABLE $6.1-1$

GOOD PRACTICE TECHNIQUE RATINGS

Good Practice Ratings

Decommissioning phase

Radiological Characterization Segregation of Waste Magnets for Lifting Prior Removal of clean Components Urethane Foam/Spray Fixing Air Filtration/Pressure Gradients Segmenting under Negative Pressure On-Job Training of Work Force Post-Activity Debriefings Testing/Training with Mockups Use of site as Training Center On-site Radiological Laboratory a Mobile Shielded Work Stations

\section{operations phase}

Comprehensive Data Base Segregation of oil Bearing Waste

Maintain Storage Pools

\section{Design Construction Phase} tion scale Models Construct Remote Sampling/Measuring Sealed Nonporous Insulation Enclosed Cable Trays Minimize Cable Trays in Contaminated Areas

Relocated Motor Control Centers Sufficient Waste Storage Capacity Bolted Steel Construction

Flanged Construction of Components Quick Disconnect of Components Shearable Nuts and Bolts Non-Embedment of Pipes in Concrete Removable Roof, Wall panels/Plugs Access to and into ali Tanks plant Breathing Air Supply System Pre-Installed Manipulator support Lifting Lugs on Large components Anchor Points for Lifts Tracks for Remote Cutting Devices Preplaced Core Samples Complete Drainage Capacity ..to identify/locate extent of contamination for ALARA planning ...to minimize burial volume by controlled separation

...to minimize exposure when removing contaminated components

...to control cross-contamination during dismantling process

... of contaminated components to reduce exposure

...to control and limit spread of contamination

...to minimize airborne releases and subsequent contamination ...to reduce exposure during unique dismantling activities

...to reduce exposure be preparing for efficient time management ...to reduce exposure during actual dismantling effort

...to reduce both exposure and waste volume by prior practice

...to expedite process of categorizing waste

...to minimize exposure during removal activities

...to accurately record plant data necessary for decommissioning

...to reduce damage to waste handling systems

...for future use as segmentation pools during dismantling

Exposure Waste cost overall

$\begin{array}{rrrr}+1 & +1 & -1 & +1 \\ -1 & +1 & -1 & -1 \\ +1 & 0 & -1 & 0 \\ -1 & +1 & 0 & 0 \\ +1 & 0 & 0 & +1 \\ +2 & 0 & 0 & +2 \\ +1 & +1 & 0 & +2 \\ +1 & +1 & -1 & +1 \\ +1 & +1 & 0 & +2 \\ +2 & 0 & -1 & +1 \\ +1 & +1 & -2 & 0 \\ 0 & +1 & 0 & +1 \\ +2 & 0 & -1 & +1\end{array}$

... for clearances evaluation during removal of contaminated equipment ..to reduce exposure and improve time efficiency

...to reduce contamination and subsequent waste volume

...to reduce cable tray waste volume and incurred removal exposures

...to minimize subsequent volume of radwaste

...to reduce waste by minimizing potential equipment contamination

...to circumvent critical path items and facilitate waste removal

...to reduce exposure by decreasing disassembly time

...to decrease exposures by eliminating contamination in dismantling ...to decrease exposure by remote or more efficient dismantling

...to reduce exposure by allowing for remote segmentation

...to reduce removal and dismantling effort

...to improve access for removal of radioactive components

... to allow for decontamination by water lancing or entry

...to increase worker efficiency and reduce time and exposures

...to provide contamination-free access for partial reactor removal

...to expedite rigging time and reduce exposures

...to reduce exposure time spent rigging for component removal

... to reduce exposure incurred in dismantling of activated components

...to minimize exposures when characterizing activated concrete

...to reduce exposures by eliminating crud traps 
$\underline{\text { Rating ' }}$

2

1

$\emptyset$

Technique provides positive contribution to facilitating decommissioning process by reduction of occupational exposure

Technique provides positive contribution to facilitating decommissioning process by reduction of waste burial volume

Technique provides no contribution to reducing occupational exposure or waste volume

Technique provides negative benefits to reducing burial volume; i.e., the technique would increase waste volume.

Technique provides negative benefit to reduce exposure; i.e., technique would increase occupational exposure

The remaining techniques were included on the basis of detailed cost benefit analyses. These techniques were ranked according to their cost effectiveness as a means of establishing a common basis for evaluation of exposures and waste generation. Table 6.1-2 presents a compiled summary of the results of each evaluation, identifying the net exposure and waste reduction and the cost associated with achieving those reductions. The results presented in this table are based on the exposure or waste reduction contribution of the technique and its applicability to the reference PWR and BWR stations.

Quantitative summaries for each of the following facilitation techniques is provided in Table 6.1-2.

1 Reactor Type

The reactor type identifies either PWR or BWR for their applicable results. A "General" classification is assigned when evaluation results are similar for either PWR or BWR, within the range of this report.

2 Exposure Reduction

The exposure reduction category presents the manRem reduction achieved for a particular technique when applied to the reference reactor type. Note that parentheses ( ) indicate negative exposure reduction (increase in exposure) when implementing the technique. 
TABLE $6.1-2$

QHANTITATIVE RESULTS OF FACILITATION TECHNIQUES EVALUATED BY COST-BENEFIT ANALYSES

\begin{tabular}{|c|c|c|c|c|c|c|c|c|c|}
\hline \multirow[b]{2}{*}{ Technique } & \multicolumn{5}{|c|}{ Occupational Exposure Impact } & \multicolumn{4}{|c|}{ Radioactive Waste Volume Impact } \\
\hline & $\begin{array}{l}\text { Reactor } \\
\text { Type }\end{array}$ & $\begin{array}{r}\text { Exposure } \\
\text { Reduction } \\
\text { (manRem) }\end{array}$ & $\begin{array}{l}\text { of Event } \\
\text { Exposure } \\
\text { Reduction } \\
(8)\end{array}$ & $\begin{array}{l}\text { Cost } \\
\text { per man- } \\
\text { Rem Saved } \\
\text { ( } \$ / \text { manRem) }\end{array}$ & $\begin{array}{l}\text { Oof Total } \\
\text { Exposure } \\
\text { Reduction } \\
\text { ( } 8 \text { ) }\end{array}$ & $\begin{array}{l}\text { Waste } \\
\text { Volume } \\
\text { Reduction } \\
(\text { cu } f t)\end{array}$ & $\begin{array}{l}\text { of Event } \\
\text { Burial vol. } \\
\text { Reduction } \\
\text { ( } 8 \text { ) }\end{array}$ & $\begin{array}{l}\text { Cost per } \\
\text { Cubic Foot } \\
\text { Saved } \\
\text { (\$) }\end{array}$ & $\begin{array}{l}\text { Reduction } \\
\text { of rotal } \\
\text { Buxial vol. } \\
\text { (z) }\end{array}$ \\
\hline \multirow{7}{*}{$\begin{array}{l}\text { Decommissioning Phase } \\
\text { Waste Compaction } \\
\text { Railcar Casks } \\
\text { Homogenized Ship- } \\
\text { ments } \\
\text { Cask Liner Geometry } \\
\text { End of Life Decon }\end{array}$} & & & & & & & & & \\
\hline & General & 15 & 61 & $(86,880)$ & 1.2 & 40475 & 68 & $(32)$ & 6.6 \\
\hline & $\begin{array}{l}\text { PWR } \\
\text { PWR }\end{array}$ & negligible & $\langle\overline{1}$ & & $\begin{array}{l}<0.1 \\
<0.1\end{array}$ & $\begin{array}{l}3689 \\
2380\end{array}$ & $\begin{array}{l}77 \\
45\end{array}$ & $(1894)$ & $\begin{array}{l}6.5 \\
8.4\end{array}$ \\
\hline & BWR & $<1 \emptyset$ & $<1$ & & $<0.1$ & 4781 & 33 & & 8.8 \\
\hline & PWR & (8) & (4) & $(115,615)$ & $(0.6)$ & 5580 & 30 & (162) & 0.9 \\
\hline & PWR & 3484 & 89 & 330 & 68 & $(4700)$ & 12 & 245 & $(0.8)$ \\
\hline & BWR & 4453 & 89 & 521 & 66 & (11299) & 132 & 205 & $(1.8)$ \\
\hline \multirow[t]{2}{*}{ Incineration } & PWR & (1) & $(255)$ & $(66,000)$ & $(<\varnothing .1)$ & 9178 & 91 & (8) & 1.5 \\
\hline & BWR & (2) & $(410)$ & $679,000)$ & $(0.1)$ & 21680 & 90 & (62) & 3.6 \\
\hline \multirow{7}{*}{$\begin{array}{l}\text { Decon Facility } \\
\text { Explosive Cutting } \\
\text { Intact Removal } \\
\text { Rail/Barge Shipment }\end{array}$} & General & (21) & 100 & 46,590 & $(1.7)$ & 7480 & 90 & 397 & 1.2 \\
\hline & General & 135 & $\begin{array}{r}100 \\
33\end{array}$ & (0) & 10.6 & negligible & $<1$ & 331 & $\stackrel{1.2}{-}$ \\
\hline & General & 474 & 83 & 115 & 37.3 & 1398 & 11 & 39 & 0.2 \\
\hline & PWR & 242 & 53 & $(16601)$ & 19.0 & 8437 & 17 & $(476)$ & 1.4 \\
\hline & BWR & 121 & 16 & 2923 & 6.9 & 9630 & 16 & 37 & 1.6 \\
\hline & PWR & 14 & 100 & 7164 & 1.1 & negligible & $<1$ & - & - \\
\hline & BWR & 46 & 100 & 2274 & 2.6 & negligible & $<1$ & - & - \\
\hline \multicolumn{10}{|l|}{ Operations Phase } \\
\hline \multirow{3}{*}{$\begin{array}{l}\text { Repassivation } \\
\text { Incineration } \\
\text { Preoperational } \\
\text { Electropolishing }\end{array}$} & General & 30 & 20 & 753 & 2.4 & (83) & (23) & (274) & $<0.1$ \\
\hline & General & (2) & (89) & $(93,811)$ & $(<\theta .1)$ & 7239 & 93 & & 1.2 \\
\hline & General & 17 & 20 & $(837)$ & 1.0 & & & & \\
\hline \multirow{5}{*}{$\begin{array}{l}\text { Design construction } \\
\text { Canal Gate } \\
\text { Liquids Containment } \\
\text { Blast Holes }\end{array}$} & & & & & & & & & \\
\hline & PWR & 53 & 17 & (2244) & 4.2 & 620 & (4) & (192) & \\
\hline & General & $<10$ & 10 & 25,000 & 10 & 396 & 10 & 135 & 10 \\
\hline & PWR & 72 & 100 & (163) & 5.7 & negligible & $<1$ & - & - \\
\hline & BWR & 160 & 100 & $(164)$ & 9.1 & negligible & $<1$ & - & -- \\
\hline \multirow{3}{*}{$\begin{array}{l}\text { Smooth/Coat Concrete } \\
\text { Substitute/Purify } \\
\text { Modular Biological } \\
\text { Shield }\end{array}$} & General & $(36)$ & (117) & (5151) & $(2.8)$ & 3000 & 77 & $(6)$ & 0.5 \\
\hline & General & 16 & & 60340 & $(1.3)$ & 612 & 7 & 1530 & 0.1 - \\
\hline & PWR & & & & & 11,300 & 73 & (35) & 1.9 \\
\hline
\end{tabular}

Although Cost Benefit studies are recommended for Worker Training and Comprehensive Data Base, none were prepared for this study due to the site-specific nature of the analyses. 
This category represents the percent reduction in manRem exposure from the base case event. Specific dismantling work activities are identified in each of the detailed evaluation descriptions of chapters 3,4 and 5 .

4 Cost Per ManRem Saved

This category identifies cost per manRem for implementing a technique to achieve net exposure reduction. Parentheses indicate reduction in cost for the technique used. Costs presented represent all cost elements (labor, materials, packaging, shipping and burial fees) associated with implementing a technique.

5 Percent of Total Exposure Reduction

This category represents percent reduction or increase to total manRem exposure incurred during base case dismantling activities. Total base case exposure estimates were taken as 1271 and 1764 manRem, as identified in the reference PWR and BWR studies, respectively. These estimates are exclusive of exposure incurred during discharge and shipment of fuel.

6 Waste Volume Reduction

This category identifies the total reduction in radioactive waste burial volume in cubic feet when the technique is applied to a specific dismantling work activity. Parentheses indicate increase in burial waste volume.

7 Percent of Event Burial Volume Reduction

This category represents percentage of burial volume reduction achieved over the base case event. Specific work activities are identified in each of the detailed evaluation descriptions of Chapters 3 , 4 and 5 .

8 Cost Per Cubic Foot Saved

This category identifies the cost, on a per cubic foot saved basis, to implement a particular technique. The parentheses indicate reduction in cost if the technique were implemented. 
Percent Reduction of Total Burial Volume

This category represents the percent of reduction in burial volume to the base case burial volume generated during an entire decommissioning project. The total burial volume values of 609,853 and $616,228 \mathrm{cu} f t$ were taken from the PWR and BWR studies, respectively.

The reviewer should keep in mind that the results presented here are specific to the exposure or waste volume scenario of the facilitation technique within the site characteristics of the referenced stations. These results will vary by plant and with any change in the scope of the technique's application. Each of the techniques presented has the potential of providing additional benefits but should be ensured on a site-specific basis.

6.2 RESULTS OF TECHNIQUE RANKING

Detailed cost benefit analyses provided the basis for the ranking of the cost benefit facilitation techniques. Ranking for these was on the basis of the technique's contribution to reducing the overall occupational exposure, waste volume and cost. Table 6.2-1 presents the results of the ranking of the techniques evaluated by cost benefit analyses within each reactor life phase. The eleven techniques of the decommissioning phase were ranked in numerical order in accordance with their benefit for reductions in exposures, wastes and costs (one being the highest in reductions). A similar approach was used for the three techniques in the operations phase and the five techniques in the design/ construction phase. 
TABLE $6.2-1$

\section{COST BENEFIT TECHNIQUE RANKINGS}

Relative

Decomaissioning Phase

Waste Compaction

Railcar Shipping Casks

Homogenization of Cask shipments

Cask Liner Geometry

Cask Liner Geometry

ntamination

Incineration

On-site Decon Facility

Explosive Cutting

Intact Removal

Rail/Barge shipment

i

Robotics

\section{$\checkmark$ Operations phase}

Repassivation

Incineration

Preoperational Electropolishing

Design Construction phase Canal Gate

Comprehensive Data Base

Containment of Liquids

Preplaced Blast Holes

Smooth and Coat Concrete surfaces

Substitute/Purify Materials

Modular Biological shield ...of small bore piping, conduit, cable trays

... for shipment of radwaste to burial ground

...to optimize NSSS packaging for transport/burial

..to optimize liner geometry/waste configuration

. of primary NSS system

..of dry active radwaste during dismantling

..to process small contaminated equipment

. of primary piping and components in high radiation areas

...for large contaminated components

..of all radioactive waste to burial

...for removal of highly activated concrete

... of decontaminated systems/components prior to return to service $\ldots$ of dry active waste during plant operation

..to minimize collection of radioactive crud in plant systems

to segregate reactor cavity and refueling canal for segmentation

...to accurately record plant data necessary for decommissioning

. to minimize spro

...for future demolition of bioshield concrete

...to minimize penetration of contamination

...to minimize NSSS activation products

...to optimize removal of activated material 
3-15 "Incineration of Radioactive waste from Nuclear Power Reactors," Radovan Kohout, Ontario Hydro, 1983.

3-16 L.M. Klinger, "Mound Cyclone Incinerator, Volume 1, Description and Performance," Mound Laboratory,

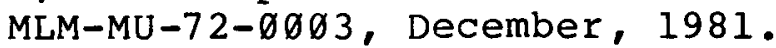

3-17 R.J. Tosetti, "State, Federal, Nuclear Interface Approaches to Volume Reduction," ANS Executive Conference, Monterey CA, February 2-4, 1981.

3-18 Atomic Industrial Forum, Washington, D.C., INPO, Atlanta, Georgia.

3-19 Nuclear Regulatory Commisison, Regulatory Guide 1.86, "Termination of Operating Licenses for Power Reactors," June, 1974.

3-2ø J.T. MCVey, C. Campuzano and D.E. Fowler, "Tools and Equipment: From Nuclear Waste to Reusable Items," Nuclear and Chemical Waste Management, Vol. 2, pp 197-2øø, 1981.

3-21 Product Information Bulletins: (1) Health Physics Systems, Inc., (2) Turco products, and (3) Vikem Industries.

3-22 Product Information Bulletin, Jet Research, Inc., Arlington, TX.

3-23 product Information Bulletin, Explosive Technology, Inc., Fairfield, CA.

3-24 G. R. Hoenes, et al., "Radiological Assessment of Steam Generator Removal and Replacement: Update and Revision," NUREG/CR 1595 (PNL-3454), Pacific Northwest Laboratory.

3-25 Nuclear Regulatory Commission, "Advisory Committee on Reactor safeguards subcommittee on surry Nuclear Station Steam Generator Replacement Program," NRC PDR A4.10.1, January 23, $198 \emptyset$.

3-26 General Electric, IF-3øø Railcar Cask.

3-27 EPRI Journal, November, 1984.

3-28 J.M. Halter et al., "Surface Concrete Decontamination Equipment Developed by Pacific Northwest Laboratories, PNL-4029, August, 1982 . 


\section{BIBLIOGRAPHY}

1. Nuclear Facility Decommissioning and Site Remedial Actions, Vol. 1-4

ORNL/EIS-154

RLO/SFM-8Ø15

Oak Ridge National Lab, Union Carbide (1980)

2. Compilation and Analysis of Data on Occupational Radiation Exposure Experienced at Operating Nuclear Power Plants

AIF/NESP-ØØ5

Atomic Industrial Forum

National Environmental Studies Project (1974)

3. An Engineering Evaluation of Nuclear Power Reactor Decommissioning Alternatives

$A I F / N E S P-\emptyset \emptyset 9$ (\& $\varnothing \emptyset 9$ SR)

Atomic Industrial Forum

National Environmental Studies Project

(1976)

4. Potential. Benefits of Reducing Occupational Radiation

Exposure

AIE/NESP $\emptyset I \emptyset \mathrm{R}$

Atomic Industrial Forum

National Environmental Studies Project

(1979)

5. Compendium of Design Features to Reduce Occupational Radiation Exposure at Nuclear Power Plants

AIF/NESP $\emptyset 2 \emptyset$

Atomic Industrial Forum

National Environmental Studies Project (1981)

6. Analysis of Nuclear Power Reactor Decommissioning Costs

AIF/NESP- $\emptyset 21$

Atomic Industrial Forum

National Environmental Studies Project

(1981) 
7. Decommissioning Handbook

$\mathrm{DOE} / \mathrm{EV} / 10128-1$

Nuclear Energy Services, Inc.

Prepared for US DOE

$(1980)$

8. Decontamination of Nuclear Facilities, Vol. 1\&2

International Joint Topical Meeting

ANS /CNA

(1982)

9. Proceedings of the 1982 International Decommissioning Symposium, Vol. I\&2

Seattle, Washington

Sponsored by U.S. DOE Remedial Action Program (1982)

10. Decommissioning Commercial Nuclear Facilities: A Review and Analysis of Current Regulations

NUREG/CR- $\emptyset 671$

Battelle Pacific Northwest Laboratory

Prepared by A. Schilling, H. Lippek, P. Tegeler \& J. Easterling, for US NRC

(1979)

11. Decontamination Processes for Restorative Operations and as a Precursor to Decommissioning: A Literature Review

NUREG/CR-1915, PNL-37ø6

Battelle Pacific Northwest Laboratory

Prepared by J. Nelson \& J. Devine, for US NRC (1981)

12. Technology, Safety, and Costs of Decommissioning Reference Light Water Reactors Following Postulated Accidents

NUREG/CR-26ø1

Battelle Pacific Northwest Laboratory

Prepared by E.S. Murphy, G.M. Holter for US NRC (1982)

13. Planning Guidance for Nuclear Power Plant Decontamination NUREG/CR-2963, PNL-4585

Battelle Pacific Northwest Laboratory

Prepared by L. Munson, J. Devine \& J. Martin, for US NRC (1983) 
14. Evaluation of Nuclear Facility Decommissioning Projects (Summary Report: Elk River Reactor)

NUREG/CR-2985

UNC Nuclear Industries

Prepared by R. Miller \& J. Miller, for US NRC (1982)

15. Evaluation of Nuclear Facility Decommissioning Projects (Summary Report: Enrico Fermi-l Reactor)

NUREG/CR-3116

UNC Nuclear Industries

Prepared by B. Link \& R. Miller, for US NRC (1983)

16. Evaluation of Nuclear Facility Decommissioning Projects (Summary Report: Ames Laboratory Research Reactor)

NUREG/CR-3336

UNC Nuclear Industries

Prepared by B. Link \& R. Miller, for US NRC (1983)

17. Evaluation of Nuclear Facility Decommissioning Projects (Summary Report: North Carolina state University Research \& Training Reactor)

NUREG/CR-337Ø

UNC Nuclear Industries

Prepared by B. Link \& R. Miller, for US NRC (1983)

18. Facilitation of Decommissioning Light water Reactors

NUREG/CR- $\emptyset 569$

Battelle Pacific Northwest Laboratory

Prepared by E. Moore, for US NRC

(1979)

19. Technology, Safety and Costs of Decommissioning a Reference Pressurized Water Reactor Power Station

NUREG/CR- $\emptyset 13 \emptyset$ (\& Addendum 1)

Battelle Pacific Northwest Laboratory

Prepared by R. Smith \& L. Polentz, for US NRC (1979) 
20. Effects on Decommissioning of Interim Inability to Dispose of Wastes off-Site

Addendum 2 and 3 of NUREG/CR- $\emptyset 13 \emptyset$

Battelle Pacific Northwest Laboratory

Prepared by G. Holter \& E. Murphy, for US NRC (1983)

21. Technology, Safety and Costs of Decommissioning a Reference Low-Level Waste Burial Ground, Vol. I\& 2

NUREG/CR- $\varnothing 57 \emptyset$

Battelle Pacific Northwest Laboratory

Prepared by E. Murphy \& G. Holter, for US NRC (198ø)

22. Technology, Safety \& Costs of Decommissioning a Reference Boiling Water Reactor Power Station, Vol. 1\&2

NUREG/CR- $\emptyset 672$ (\& Addendum)

Battelle Pacific Northwest Laboratory

Prepared by H. Oak, G. Holter, W. Kennedy \& G. Konzek, for US NRC

$(1980)$

23. Technology, Safety and Costs of Decommissioning Nuclear Reactors at Multiple-Reactor Stations

NUREG/CR-1755

Battelle Pacific Northwest Laboratory

Prepared by N. G. Wittenbrock, for US NRC (1982)

24. Technology, Safety \& Costs of Decommissioning Reference Nuclear Research and Test Reactors

NUREG/CR-1756 (\& Addendum)

Battelle Pacific Northwest Laboratory

Prepared by G. Konzek, for US NRC (1983)

25. Estimated Quantities of Materials Contained in a $1 \emptyset \emptyset \emptyset$ MWe PWR Power Plant

ORNL-TM-4515

Oak Ridge National Laboratory, Union Carbide Prepared by R. Bryan \& I. Dudley, for US NRC (1974) 
26. Waste, Containers for Decommissioning

DOE/RLO-SFM-82-6

UNC Nuclear Industries

Office of Surplus Facilities Management Program

Prepared for the US Department of Energy (1982)

27. Actions Being Taken to Help Reduce Occupational Radiation Exposure at Commercial Nuclear Power Plants

GAO/EMD-82-91

Report to Senator John Glenn from the General Accounting office

(1982)

28. Evaluation of Non-Chemical Decontamination Techniques for Use on Reactor Coolant Systems

EPRI $-\mathrm{NP}-2690$

Electric Power Research Institute

Prepared by Quadrex Corporation

(1982)

29. Evaluation of Abrasive Grit High Pressure Water Decontamination

EPRI -NP-2691

Electric Power Research Institute

Prepared by Westinghouse Electric Corporation (1982)

30. An Assessment of Chemical Processing for the Post Accident Decontamination of Reactor Coolant Systems

EPRI-NP-2866, Project 2012-1

Battelle Pacific Northwest Laboratory

Prepared for Electric Power Research Institute (1983)

31. Low-Level Radwaste Solidification

EPRI-NP-29ø0, Project 1557-1

Sargent \& Lundy Engineers

Prepared for Electric Power Research Institute (1983)

32. Characterization of Contaminants in TMI-2 Systems

EPRI-NP-2922, Project 2ø12-3

Science Applications, Inc.

Prepared for Electric Power Research Institute

(1983) 
33. Building Construction Cost Data Robert Snow Means Company, Inc. (1984)

34. Mechanical and Electrical Cost Data Robert Snow Means Company, Inc. (1984)

35. General Construction Estimating Standards Richardson Engineering Services, Inc. (1984)

36. Management of Low-Level Radioactive Waste Vol $1 \& 2$ Edited by M. Carter, A. Moghissi, and B. Kahn Pergamon Press (1979)

37. Nuclear Power Waste Technology Edited by A. Moghissi, et al. American Society of Mechanical Engineers (1978)

38. Radioactive Waste Technology Edited by A. Moghissi, et al. American Society of Mechanical Engineers (1986)

39. Decontamination of Nuclear Reactors and Equipment J. A. Ayres The Ronald Press Company, New York (1970)

40. Decommissioning and Decontamination of Nuclear Facilities, Proceedings of a Conference, Sun Valley, Idaho CONF -790923

(1979)

41. American Nuclear Society 1978 winter Meeting, Proceedings of a Conference, Washington, D.C. CONF -7811109

(1978) 
42. The Communities' Research and Development Programme on Decommissioning of Nuclear Power Plants First Annual progress Report (1980)

EUR 7440

Commission of the European Communities (1981)

43. The Communities' Research and Development Programme on Decommissioning of Nuclear Power Plants Second Annual Progress Report (1981)

EUR 8343

Commission of the European Communities (1983)

44. A Utility Perspective on Needs for Technical Advances in Nuclear Decommissioning

Daniel H. Williams ASME 83-JPGC-NE-17 (1983)

45. Design Recommendations to Simplify Nuclear Facility Decommissioning - Presented at the Specialist Meeting on Decommissioning Requirements in the Design of Nuclear Facilities

B.F. Ureda, W.D. Kittinger, G.W. Meyers (1980)

46. Features to Consider at the Design Stage to Aid Decommissioning

D.A. Chapman

United Kingdom Atomic Energy Authority

(1980)

47. Some Decommissioning Aspects of the Civil Engineering Design of Nuclear Plant

S.K. Menon, S.Karker, H. Cederberg

Swedish State Power Board

Stockholm, Sweden

(1980)

48. Experience in the Replacement of the Failed Acid Evaporator at the Tokai Reprocessing Facility - Presented at the Specialist Meeting on Decommissioning Requirements in the Design of Nuclear Facilities

S. Hayashi, S. Araya, I. Tanaka

(1980) 
49. Design Features Aimed at Minimizing Radiation Doses, During Decommissioning

M.Laraia, G. Saponaro

Comitato Nazionale Energia Nucleare (CNEN)

Rome, Italy

(1980)

50. Influence of Activation, Decay Behavior and Amount of Radioactive waste Due to Various Chemical Elements in the Structural Materials Surrounding the Reactor Core - Presented at: Specialist Meeting on Decommissioning Requirements in the Design of Nuclear Facilities

W.M. Francioni, G. Megaritis

Swiss Federal Institute for Reactor Research $\mathrm{CH}-5303$

Wurenlingen, Switzerland

(1980)

51. Radiation Protection Requirements to be Taken into Account in the Design of Nuclear Facilities in View of Their Decommissioning

A. Benco

Commission of the European Communities

Ispra, Italy

$(1980)$

52. Waste Management Requirements to be Taken into Account in the Design of Nuclear Facilities in View of Their Decommissioning

I. Auler, Nuklear-Ingenieur-Service GmbH, Frankfurt

W. Brewitz, Gesellschaft fur strahlen und Umweltforschung $\mathrm{mbH}$, Braunschweig

H. Reichenbecher, Stahlwerke Peine-Salzgitter AG,

Salzgitter

Federal Republic of Germany

(198ø)

53. Sodium Reactor Experiment Decommissioning Final Report

ESG-DOE-134ø3

J.W. Carroll, C.C. Connors, J.M. Harris, J.M.

Marzec, and B.F. Ureda

(1983) 
SECTION A-1

TECHNIQUES PREPARED FOR STUDY

\begin{tabular}{llll}
\hline 1 & D & Radiological Characterization & GP \\
2 & D & Segregation of Waste & GP \\
3 & D & Magnets for Lifting & GP \\
4 & D & Prior Removal of Clean Components & GP \\
5 & D & Urethane Foam/Spray Fixing & GP \\
6 & D & Air Filtration/Pressure Gradients & GP \\
7 & D & Segmenting Under Negative Pressure & GP \\
8 & D & On-Job Training of Work Force & GP \\
9 & D & Post-Activity Debriefings & GP \\
10 & D & Testing/Training with Mockups & GP \\
11 & D & Use of Site as Training Center & GP \\
12 & D & On-Site Radiological Laboratory & GP \\
13 & D & Mobile Shielded Work Stations & GP \\
14 & D & Waste Compaction (Combined) & CB \\
15 & D & Railcar Shipping Casks & CB \\
16 & D & Homogenization of Cask Shipments & CB \\
17 & D & Cask Liner Geometry & CB \\
18 & D & End of Life Decontamination & CB \\
19 & D\&O & Incineration & CB \\
$2 \emptyset$ & D & Worker Training & CB \\
21 & D & On-Site Decon Facility & CB \\
22 & D & Explosive Cutting & CB \\
23 & D & Intact Removal & CB \\
24 & D & Rail/Barge Shipment & CB \\
25 & D & Robotics & CB
\end{tabular}

26 O\&DC Comprehensive Data Base GP

27 Segregation of Oil Bearing wastes GP

28 Maintain Storage Pools GP

29 O Repassivation (Combined) CB

19 O\&D Incineration CB

30 Preoperational Electropolishing CB

31 DC Construction scale Models GP

32 DC Remote Sampling/Measuring GP

33 DC Sealed Nonporous Insulation GP

34 DC Enclosed Cable Trays GP

35 DC Minimize Cable Trays in Contaminated Areas GP

36 DC Relocated Motor Control Centers GP

37 DC Increase waste storage Capacity GP

38 DC Bolted steel Construction (Combined) GP

39 DC Flanged Construction of Components GP 


\begin{tabular}{llll}
\hline 40 & DC & Quick Disconnect Components & GP \\
41 & DC & Shearable Nuts and Bolts & GP \\
42 & DC & Non-Embedment of Pipes (etc.) in Concrete & GP \\
43 & DC & Removable Roof, Wall Panels/Plugs & GP \\
44 & DC & Access to and into All Tanks & GP \\
45 & DC & Plant Breathing Air Supply System & GP \\
46 & DC & Pre-Installed Manipulator Support & GP \\
47 & DC & Lifting Lugs on Large Components & GP \\
48 & DC & Anchor Points for Lifts & GP \\
49 & DC & Tracks for Remote Cutting Devices & GP \\
50 & DC & Preplaced Core Samples & GP \\
51 & DC Complete Drainage Capacity & GP \\
26 & DC\&O Comprehensive Data Base & CB \\
52 & DC Canal Gate & CB \\
53 & DC & Containment of Liquids & CB \\
54 & DC & Preplaced Blast Holes & CB \\
55 & DC & Smooth \& Coat Concrete Surfaces (Combined) \\
56 & DC Substitute/Purify Materials & CB \\
57 & DC & Modular Biological Shield &
\end{tabular}




\author{
SECTION A-2 \\ TECHNIQUES COMBINED UNDER ONE CATEGORY FOR STUDY
}

No. Technique

Combined

Category

58 Crush/Compact Thin Wall Components and Piping

14

This technique would reduce waste volume by compaction prior to packaging. Small bore piping and thin gage components, panels, and casings could all be crushed by ultra compaction equipment. Compaction could be performed in a shipping container to minimize handling.

59 Maximize Packaging Efficiency (Shredding and Vibrating) 14

This technique would decrease the number of packages required for disposal of a given volume by increasing the packing efficiency of the container. Packing efficiency would be increased by reducing interstitial voids and thus promoting settling, thus promoting more efficient container usage. This technique could be accomplished by either reducing the waste size for improved packing or by using vibration techniques to induce settling in the container.

60 Tubing and wire cutter-Crusher

This technique would reduce the number of containers required for disposal of contaminated tubing and wire by maximizing the container packing efficiency. Tubing/wire would be crushed and chopped into small segments, greatly reducing the usual voids generated in packaging these materials due to coiling and unyielding geometries.

61 Pre-oxidation for Corrosion Resistance

This technique, implemented before plant startup, would improve corrosion resistance and reduce crud film and the associated radiation field. Filling and overheating primary/auxiliary water to higher than its operating temperature would promote interior surface oxidation and create a film that would be highly resistant to contamination. Temperature and pressures should be kept within design specifications. 
62 Replace or Cover Concrete surfaces with steel

This technique would decrease the waste volume for controlled disposal by allowing for material reclamation. Steel would be used on a cost effective basis as a replacement for concrete to allow for more dismantling material to be disposed of as clean scrap or through salvage. Steel would also decontaminate more easily, allowing for increased recovery of materials.

63 Grout Surface Irregularities

This technique would minimize the formation of crud traps by removing discontinuities from surface transitions. Grout could be used to create continuous transitions between surface and material interfaces, eliminating crevices that trap contaminants and create concentrated radiation sources. 
SECTION A-3

REJECTED TECHNIQUES

No.

Technique

\section{Concrete Crushing}

This technique would decrease the number of packages required for disposal of a given volume of radioactive concrete by increasing the packing efficiency of the container. Concrete would be crushed to decrease voids created in packing by irregularities in waste geometry. Containers for concrete would be designed for maximum theoretical loads to accommodate greater packing densities.

The existing methods to demolish concrete can achieve the same results without incurring the additional costs to procure an expensive crusher that would eventually become contaminated. The double handling required to further crush concrete is not warranted.

\section{Disposable Cable sleeving}

This technique would decrease the volume of contaminated cable by protecting the cable with a disposable sleeve.

However, no actual waste savings is realized since the contamination is just transferred to another host material. In addition, the effort required to remove the sleeving is not cost effective.

\section{Electrical Cable stripping}

This technique would decrease waste volume by recovering the conducting core for scrap after removing it with a pull-type die stripper.

However, this process is not expected to be cost effective and certainly is not justified by present scrap prices.

\section{Increase Void Volume with Deeper Excavation}

This technique would produce a larger void space for disposal of noncontaminated waste by placing the plant further below grade.

Excavation of this magnitude to reduce local landfill use is not justifiable on any practical basis. 


\section{Use of Arc Saw to Sever Structure}

This technique would reduce exposure for cutting activities by reducing cutting durations for the remote segmentation of complex structures, composite materials and highiy activated components. The arc saw would rapidly and cleanly cut any electrical conduction material at rates independent of material strength and ductility properties.

To date there is insufficient operating data to accurately compare arc saw cutting to other more conventional means. This technique could well provide a viable method for segmenting components; operating data from experimental or prototype units should be evaluated when available.

\section{Water Tight Compartments for cutting}

This technique allows for in-place underwater cutting of highly activated components by designing a compartment around the component that can be sealed off and flooded.

This technique requires (1) provisions for installation of watertight closures for all penetrations, and (2) structural design to accommodate additional loading. As such, it appears to be neither cost effective for incorporation in plant design nor efficient for the segmentation process.

$7 \emptyset \quad$ Periodic Decontamination

This technique would control and limit the sources of radiation within the plant during operation and the radionuclide inventory at the time of decommissioning. Reduction of radiation fields throughout the plant as an on-going activity would reduce worker exposure during maintenance and outage activities and result in lower exposures at the time of decommissioning.

However, recent performance data from operating stations have shown that recontamination is often as high and as fast as that originally incurred. Accordingly, end of life decontamination and repassivation (chosen techniques) are more reasonable techniques to consider for decommissioning. 
SECTION A-3

(Continued)

No.

Technique

71 Corrosion Allowance for Decontamination

This technique would permit periodic decontamination of the process system/component with aggressive chemicals while maintaining material design specifications. Corrosion allowance for decontamination should be considered in specifying piping schedule and material thicknesses. This would indirectly reduce exposure by allowing decontamination during the operating life of the system/component, resulting in lower radiation fields for maintenance and ultimate decommissioning.

Piping and component design selection of thickness is always rounded to the next greater wall thickness available from manufacturers. Since decontamination removes (at most) not more than a few mils of wall thickness, there is no need to increase wall thickness for decontamination acid attack. Accordingly, this technique was judged unnecessary.

72 Sacrificial Liners and Bladders

This technique would use sacrificial liners/bladders to protect supporting structures from contamination. These liners could then be recovered by originally using materials easily decontaminated.

However, it is too difficult to provide multiple penetrations through such a liner and impractical to expect to avoid liner ruptures from such activities as welding.

73 HEPA Filtered Motor Control Center Cooling Fans

HEPA filters would inhibit the spread of contamination but would increase maintenance requirements. In addition, they pose the potential safety problem of becoming plugged and preventing cooling air flow.

74 Color Code piping and Components

This technique would speed the segmentation and removal process and thereby lower occupational exposure. By color coding piping at the time of construction as "radioactive" or "clean," workers would know what items could be removed with or without restrictions. 
This technique was rejected because (1) color coding may promote a false sense of security and circumvent proper practice of radiological characterization prior to performing work, (2) coding must be maintained for the life of plant, thus adding a maintenance task, and (3) the actual benefit may be nil.

\section{Secondary Radwaste Facility}

This technique would provide radwaste treatment facilities to replace limited existing process equipment by adding additional storage and treatments for the large influx of decommissioning fluids (hydrogen, water, chemical decontamination solutions, etc.). Treatment of radwaste is a critical path item; the inability to process waste at a sufficient rate may cause interruption of waste treatment tasks.

Since modern operating stations have adequate processing capacities to handle the liquid wastes generated during decommissioning, the additional expense to augment these systems is not warranted.

\section{Shielded Disassembly/Packaging Area}

Disassembly of larger items in a more radiologically controlled environment could be accomplished by providing a facility with special shielded work and laydown areas. These areas would provide contamination control for the cutting/disassembly tooling and the packaging preparation equipment. In such an atmosphere, wastes could be packaged in a more efficient manner, thus reducing both personnel exposures and waste. For example, components could be removed from high radiation areas in an intact or partially intact form, then further segmented and prepared for shipment within the specially shielded area. More care could then be taken to eliminate void spaces in packaging by cutting items to conforming sizes.

The double handling of large components through the power plant was judged to be too difficult to warrant the expense of constructing a shielded work facility. Furthermore, the low number of potential items for such treatment would be too small to make this technique viable. 
SECTION A-3

(Continued)

77 Construct Plant with Segmenting Pool

This technique would allow for the underwater segmentation of large radioactive components (RPV, steam generator), thus reducing exposure and generation of airborne contamination.

This technique was rejected because the additional structure would become contaminated, requiring an increase in the overall decommissioning effort and adding the exposures and wastes of removal.

78 Temporary Gutter Attachment for Washing

Installing systems to collect the contaminated water from hydrolasing would reduce wastes generated by preventing contamination spread during decontamination. Devices for attaching gutters on walls and other components would be incorporated into the construction of the plant. Then, at the time of decontamination, the gutters would be attached to divert contaminated wash water directly into drains. These gutters would be constructed of incinerable plastic and would have herculite sheets attached so that they could be sloped to divert overspray toward the gutter.

This technique was rejected because of increased exposure time needed for setup and takedown. Epoxy coating would serve better.

79 Increase Liquid Radwaste Segregation Capabilities

This technique would decrease the volume of radioactive waste generated by segregating the varieties of liquid waste for required treatment. Segregation would be accomplished by the use of multiple holdup tanks, advanced sampling, and system cross-connects. The end result would be a minimum of processing time.

The technique was rejected since the increased costs of installation for decommissioning are not outweighed by significant radwaste volume savings. Additionally, any increase in the radwaste system would add to the volume of components to ultimately be removed as radwaste. 


\section{$8 \emptyset$ Isolate Radwaste Systems from Plant}

This technique would promote maximum use of a plant's radwaste system during decommissioning. By designing the system for independent operation and isolating it from the rest of the plant, it could function independently of the plant and be available for use through the final phases of decommissioning.

This technique was rejected because an independent radwaste facility would still have to be decommissioned and may cause greater quantities of wastes to be generated due to the duplication of structures. Any benefit would be minimal.

\section{Quick Snap-on Insulation}

This technique would reduce exposure by speeding the process of removing thermal insulation from contaminated components. Sheets of insulation could be rapidly "popped" off rather than cut by more time consuming methods.

This technique was rejected because it is currently being used in the form of "mirror insulation" at most plants.

\section{Use of Nongrouted Tendons in Concrete structures}

This technique would facilitate demolition of large concrete structures such as the containment building. By not grouting the stressing tendons in-place, future demolition of the structures could be simplified by detensioning the tendons, thereby weakening the structure.

This technique was rejected since it is already standard practice (in the United states) not to grout the tendons.

\section{Consolidation of Pipe Hangars/Seismic Supports}

This technique would reduce wastes and exposures by reducing the quantity of material available to become contaminated, improving general area access, and reducing total material to be dismantled and removed. This would be accomplished by using multiple purpose hangers and supports wherever possible. 
SECTION A-3

(Continued)

This technique was rejected since the design function of pipe hangers and seismic supports is significantly different. The consolidation would most likely compromise design criteria of one or the other support systems.

Hollow Core Pillars and Honeycombed Slabs

If incorporated into the construction of a plant, this technique would reduce both the volume of material to be disposed of as radioactive/clean waste and the effort and exposure time needed for demolition.

This technique was rejected since the structural design strength needed to support buildings/structures would require larger diameter pillars and thicker floors, thus reducing available building volume needed for plant systems.

Composite shield Construction

This technique would reduce exposure time, provide cost effective disassembly, and reduce waste volume by improving segregation. Shielding walls (such as those of shield cubicles) would be constructed with inner/outer concrete or bolted steel "skins". Then, the interior void would be filled with a shielding material such as sand, lead shot or water. At the time of decommissioning, the shielding material would be drained and disposed of as clean waste. The contaminated inner/outer skins would then be prepared as radwaste.

The rigging required to remove prefabricated shield panels would be difficult to move into the proposed areas for these panels, nor would a rigging crane fit within such a work area. Furthermore, the cost would be unreasonable if these shields were manually field fabricated.

\section{Self-Contained/Sealable Components}

This technique would reduce exposure and avoid the need for the segmentation and repackaging of radioactive components. By designing components to have their own outer vessel containment, they could be disconnected to allow for shielding concrete to be poured into the outer vessel, then sealed and removed in one piece, ready for shipping. 
This technique was rejected because the outer containment vessel would hinder maintenance during the life of the plant. Access to plant areas could also be hindered by increased size in components.

\section{Collapsible systems}

This technique would aid in the removal and packaging of large radioactive components such as tanks. A large tank could be made of concrete cylinders of different radii. The vertical sections would then be separated and collapsed into themselves, forming a much smaller, self-shielding, volume reduced container to be sealed and handled as its own shipping container.

This technique was initially accepted for tank-like components only. Further investigation indicated impractical difficulties in fabricating tank sections to telescope or collapse into each other while still permitting easy joint welding.

88 Pre-Installed Platforms, Walkways, etc.

This technique would reduce exposures for three reasons: (1) needed work platforms could be built during the pre-radioactive stages of plant life, thereby reducing radiation exposure during work setup; (2) decommissioning workers would be able to commute quickly through radiation areas; (3) workers could perform their tasks more efficiently with improved platforms.

Most new power plants have provided platforms and walkways where needed to facilitate plant maintenance. Therefore, this technique is already being implemented.

\section{Access Hatches in Compartments and Shield Walls}

Access hatches would take the form of concrete plugs to be moved on rails or hoisted from overhead, thus improving the removal process of large radioactive components from within shielded compartments. Such a process would avoid the need for segmentation and allow for intact removal. This would decrease exposures and prevent both contamination spread and those airborne hazards caused by the segmentation process. 
Most new power plants have provided access hatches where needed to facilitate plant maintenance. Therefore, this technique is already being implemented.

\section{$9 \emptyset$ Containment Building with Dome Hatches to Facilitate Lifts}

This technique would provide direct access to large components in the containment building from the outside. This would enable components such as steam generators, coolant pumps and vessels to be lifted out intact by crane, thus reducing the lengthy and hazardous segmentation process and allowing for more cost effective transportation techniques (rail/barge). Thus, exposure, wastes and transportation costs would be reduced significantly.

The technique was rejected since the design difficulty in providing hatches with sufficient strength and sealing surfaces to meet the containment pressurization and leaktest criteria was judged to be unreasonable.

\section{Labyrinth Doorway Shield Walls with Removable Panels}

This technique would reduce exposures and allow for more cost effective dismantling techniques. Constructing shield walls out of removable concrete panels rather than poured concrete would allow for the intact and faster removal of interior cubicle components. Care must be taken that the shield panels are contamination resistant and constructed to permit rapid and remote disassembly.

The rigging required to remove precast concrete or steel panels would be difficult to move into the areas where the panels had been installed. In addition, the rigging crane would not fit in such work areas.

\section{Remove Radwaste Tanks through Exterior Building Walls}

This technique would provide direct access to radwaste tanks from outside the building, thus allowing for intact removal and reducing exposure time. This is accomplished by locating all radwaste tanks next to exterior walls at grade level; the exterior walls adjacent to these tanks would be constructed of blocks or panels for easy removal.

This technique was rejected for limited application. 
SECTION A-3

(Continued)

No. Technique

93 Adequate Access to Pipe Chases

This technique would provide improved access into pipe chases for the purpose of sectioning and removing pipes. Chases would be designed with sufficient access points to install cutting equipment.

This technique was rejected because of the limited benefit that it would provide.

\section{Modular Containment system}

With this technique, the design of the containment building would be altered so that each major component is housed in individual shielded cells. The cells would be built with roof hatches to facilitate intact removal. Thus, each component could be worked on without the exposure influence of other nearby components.

This technique was rejected for two major reasons: (1) it would apply only to future reactors and would not be of any benefit to today's stations; (2) the increased cost of construction and the increased volume to be decontaminated and removed do not balance against the limited benefit.

95 Increase Facility Size to Allow for Arrangement Planning

providing a larger facility would allow for improved placement of components. The potential segregation of radioactive and nonradioactive components would then allow improved access for equipment removal. This should reduce inadvertent contamination of clean components and reduce exposure while working with nonradioactive components near radiation sources.

This technique was rejected because of the increased building volume for potential contamination and the increased costs and exposures associated with decontamination and disposal. This would negate any benefit obtained from this technique.

\section{Plant-Wide Shielded Monorail system for Transport}

This technique would reduce exposures. During the construction stage, an automated monorail system would be 
installed and located in shielded corridors to transport radioactive components and packages from the work areas to radwaste shipping areas. This would avoid exposures to a forklift operator transporting radioactive sources.

This technique was rejected because a much simpler and less costly approach could be taken to reduce exposures, such as shielding a forklift. A monorail system would require extra space and would add to the volume of material for decontamination and disposal.

97 Pre-Installed Fittings on process systems

This technique would reduce equipment setup time in radiation environments and therefore reduce exposures. Fittings to allow for rapid hookup of decontamination solution circulating equipment could be pre-installed on potentially contaminated process lines at the time of plant construction. Care must be taken to avoid creating potential crud traps or leaks.

This technique was rejected since the prediction of where contamination is likely to accumulate or whether decontamination will remove/reduce radiation levels is speculative. If such fittings were installed at wrong locations, unnecessary labor and materials would be expended uselessly.

\section{Auxiliary Ventilation System}

This technique would improve the control of contamination and airborne hazards during decommissioning work. Dampers and fittings would be provided on the permanent ventilation system ductwork to allow attachment of flexible tubing or ductwork without system imbalance. This system would allow for rapid setup and would avoid the purchase and eventual contamination of many portable ventilation units.

The newly designed compact portable ventilation unit is sufficiently small to be moved easily from location to another without difficulty. The potential for contaminating permanently installed ductwork is greater than contaminating a few filter units. 
99 Pre-Installed spalling Aids

This technique would facilitate the removal of contaminated surface layer concrete, thus reducing work time and exposures. Steel plates or discs would be cast a few inches below the surface of concrete walls and floors at the time of construction. Each plate/disc is forced away from the remaining structure by applying pressurized water or air between the plate/disc and the underlying concrete structure. The contaminated surface concrete is then pulled away with the spalling plate. An alternative method of removing the spalling plate would be threaded inserts on the plate so that it could be attached to a hydraulic puller.

This technique was rejected since the prediction of where contamination will occur on a structure is speculative. If such aids were installed at wrong locations, unnecessary labor and materials would be expended uselessly. Furthermore, primary areas where such spalling aids would be installed (fuel pool, reactor cavity) are prone to exposure by contaminated liquids. The crud traps created by spalling aids would further complicate contamination.

100 Detensioning of Concrete and Insertion of Explosives

This technique would facilitate demolition of massive concrete structures such as the containment building. Detensioning stressed concrete would weaken the concrete structure and allow for easier demolition. Explosives could also be inserted into the tendon channels rather than placed into numerous pre-drilled charge holes.

This technique was rejected since, although this technique may facilitate demolition, it does not reduce exposure or waste volumes. It is also important to note that the ideal location for placement of stressing tendons may not coincide with the locations necessary for good blasting technique.

\section{$1 \emptyset 1$ Locate Flushing Connections in Low Dose Areas}

This technique would reduce occupational exposure during the hookup of chemical decontamination equipment to the primary coolant loop. Hookup connections would be installed in those areas expected to be low dose areas at the time of decommissioning. 
SECTION A-3

(Continued)

No.

Technique

The technique was rejected because the hookup connections could likely become crud traps and thus a source of exposures rather than serving to avoid other sources.

$1 \emptyset 2$ Nonchemical Decontamination

Nonchemical decontamination methods include (1) mechanical methods using wire brushes, scrapers or cutters, (2) wet abrasive techniques to incorporate abrasive grit with water jets and, (3) high pressure water blasting. These methods are designed to remove contamination and either minimize the waste generated in the process or minimize the processing required to dispose of the contaminated solutions.

These methods are currently being used to a greater or lesser extent at operating stations and are therefore not part of a new technique.

\section{System Isolation Capability for Selective Decontamination}

This technique would allow decontamination of selected portions of a system by using isolation valves in and around the system/components not compatible with decontamination processes.

However, including these additional components may create unwanted crud traps and dead legs around isolation points, thus inhibiting removal of contaminants from the system.

\section{Lighter-than-Air Lifting Devices}

This technique would facilitate intact removal of large radioactive components by lifting them through the top of buildings. Components would be lifted by a lighter-than-air lifting dirigible in conjunction with helicopters for maneuvering and power. This technique would then allow for remote transportation from the facility to navigable water or access railing for barge/rail transportation. Such removal and transportation would avoid significant exposure time during segmentation, packaging and road transportation.

This technique was rejected since it would require extensive testing, evaluation, and licensing approval, making the cost prohibitive. There are less costly, proven methods available. 


\section{Use of Portable Smelter}

This technique would reduce the volume of contaminated steel for controlled disposal by diluting the contamination to exempt concentrations and by changing the waste geometry to the most efficient packaging and shipping configuration.

The size of the smelter facility required to keep pace with removal operations so as not to become part of the critical path was judged to be too costly to be viable. Furthermore, the double handling of wastes would be too costly and could conflict with the ALARA principle of decommissioning.

\section{Abrasive Jet Concrete Cutter}

This technique of using an abrasive entrained waterjet is characterized by its high rate of cutting, flexible operation, good cut quality, and relatively low costs. Such a system still requires additional hardware engineering and adaptations for recycling the water and abrasives to minimize waste generation.

This technique was rejected since the method generates large quantities of contaminated water spray that are difficult to control and collect. The equipment required to satisfactorily collect/filter the water would not be cost effective.

\section{Heating of Rebar to Weaken Concrete structure}

This technique would reduce removal time and exposures incurred in concrete demolition by pre-weakening the concrete structure to be removed. High amperage current would be passed through the rebar to heat the steel rod. The heat would then break the bond between the steel and concrete, thereby weakening the structure.

The power required to heat the rebar was judged to be prohibitive. There are more reasonable conventional methods that would be more effective. 


\begin{abstract}
APPENDIX A
LIST OF INITIAL FACILITATION TECHNIQUES FOR CONSIDERATION

Section $A-1$ Techniques prepared for study A-2

Section A-2 Techniques Combined Under one Category for study A-4

Section A-3 Rejected Techniques A-6
\end{abstract}


No. Technique

\section{Microwave Dehydration of Concrete}

This technique would weaken a structure by dehydrating the water within the concrete. Energy efficient microwave heaters would generate the heat necessary for dehydration.

This technique was rejected since the use of microwave energy in such an application raises substantial health and safety concerns. In addition, this technique would require further technical definition and controlled testing before implementation. 


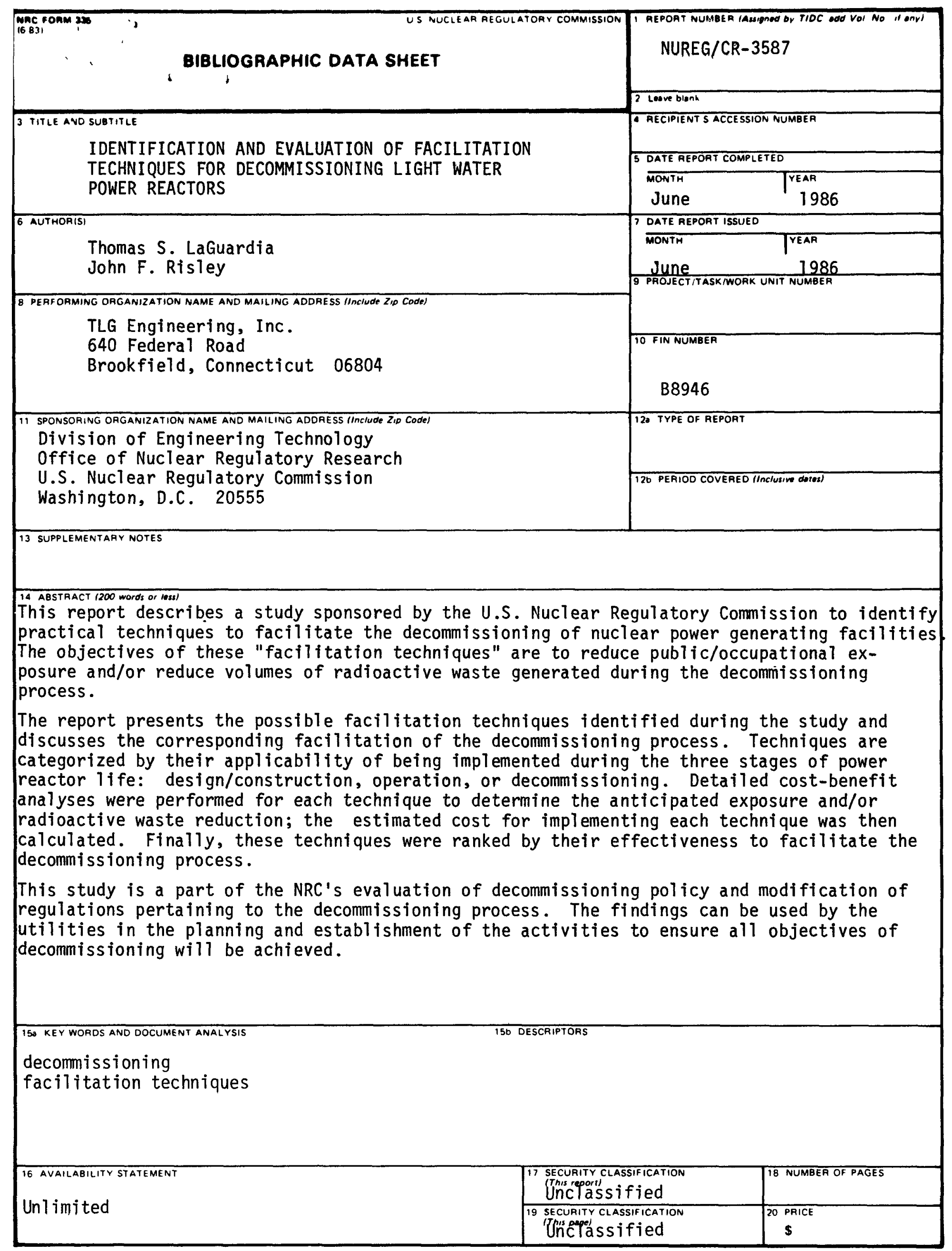

